\title{
Hydrobiological Studies on the Artificially Constructed Ponds ('Tamé-ike' Ponds) of Japan
}

\author{
(With 3 plates \& 35 text-figures)
}

By Toshihiko Mizuno

\section{INTRODUCTION}

The Japanese lakes seem to have been exhaustively studied by limnologists, but as for the ponds, which lie scattered here and there, only fragmentary reports from a number of certain particular districts have so far been published. Accordingly, there remain still many problems to be solved.

The pond is generally limited in area and of smaller depth in comparison with the lake. The artificially constructed pond very often goes down or runs dry, as its water is drained off for irrigation, local water-supply service or generation of electricity. Consequently, not only the water level changes greatly, but also the physical and chemical condititions and the state of plankton communities are subject to all sorts of external effects, thereby leading to their instability. Furthermore, as such kinds of ponds are found everywhere, i. e. on coastal areas, on tablelands, in low-lying alluvial districts and in mountainous localities, they are affected environmentally and very rich in variety. Unlike lakes, therefore, ponds naturally give students more trouble in trying to grasp their definite characters.

However, ponds, on the one hand, can be of great significance in solving problems concerning (1) the production of inland waters, (2) the relation of chemical conditions of water with biotic communities, (3) the mutual relations of one biotic community with another, and (4) the metabolism of such organic unity. Ponds, on the other hand, have come to be more and more exploited in recent years, besides lakes and rivers, for the breeding of fishes and shell-fishes. And this is why some scientifically established theories have to be found for the solution of the problems that still remain unsolved.

With a fairly large number of ponds as a subject of investigation, the present studies have been conducted from an ecological viewpoint for the purpose of finding some basic principles by trying (1) to analyse both the environmental factors and the composition of plankton communities, (2) to clarify the mutual relationship as much as possible, and thus (3) to reveal the ecosystem of their generation and metabolism. While, on the one hand, comparative studies of many ponds have been made over an extensive area, certain ponds, on the other hand, have been studied for closer observations of their seasonal fluctuations in an attempt to make clear their characteristics. 
These studies began in 1950 when the writer was at Kyoto University for a year's study, and in particular at the Ôtsu Hydrobiological Station of that university during that year and the succeeding two years. The work has since been continued in the Biological Laboratory of the Osaka University of Liberal Arts and Edudation up to the present day. The writer has all this time been under the warm guidance of Prof. Masuzo UÉNo of Kyoto University. He is especially indebted to Prof. UÉno for the identification of Cladocera, to Dr. Takashi ITô for Copepoda, to Asst. Prof. Kôkichi Yamamoto for Rotifera, and to both Drs. Ken-ichirô Negoro and Hisanao Yamaguti for algae. He is also indebted to Dr. Negoro for the instruction in chemical analyses of water samples. The writer wishes to tender his heartfelt thanks to all these learned scholars. Particular mention must also be made here of the kindness with which the Ôtsu Hydrobiological Station permitted him to make use of the related literature and the appliances necessary for the field-work. Furthermore, the writer owes a special acknowledgement to Dr. Nobumasa YAGI, his honoured teacher, for the constant encouragement and advice given him ever since he took up this research work, and to Dr. Matsunae TsudA of Nara Women's University for many valuable suggestions received when such were most needed. Thanks are likewise due to those who kindly gave him assistance in his field-work at various places.

\section{A HISTORICAL SKETCH OF POND STUDIES}

\section{a) Studies in Japan}

Limnology in Japan started in 1899 (the 32nd year of Meiji) when Dr. Akamaro TANAKA first lowered a sounding lead to the bottom of Lake Yamanaka. Subsequently, many limnologists appeared, and up to the present all the Japanese lakes have almost exhaustively been studied, thanks to their efforts. Limnological methods were later introduced into the study of ponds, but no comprehensive researches have so far been made in this country.

The ponds, especially irrigation ponds in various places have become a subject of investigation concerning their catchment water-supply, irrigation, watertemperature and geographical distribution. Hydrobiological studies, however, have hitherto been very few and far between. The pioneers in this field are Yoshimura (1925), Matsudaira (1931), Horasawa (1932), Hada (1936, 1939), Matsuyama (1939), Koiwai (1940) and Mori (1941), all of whom came out with their reports in various parts of the country. In the post-war days, HAMAI and ÔzaWA (1951) reported on the Ô-ike pond in Toyohashi City, T. Watanabe (1952) on the ponds lying on the tableland of Yamato, J. KawAMURA (1956) on the ponds in Nara City and the present writer (1952, 1953, 1954, 1955, 1957, 1957a, 1958, 1959) on the groups of ponds found on the coasts of the Inland Sea. They may be said to have clarified the characters of ponds in the some districts of Japan.

Most of these studies in the early days merely dealt with the composition and seasonal fluctuation of plankton organisms and the measurement of water- 
temperature, $\mathrm{pH}$ value and dissolved $\mathrm{O}_{2}$, but little or no efforts made for the elucidation of the relations between plankton organisms and the external factors of the ponds as well as for that of their generations and metabolism. Both $\mathrm{Cl}$ ion content and effects of the sea, however, were made by KURASHIGE (1933), Yoshimura $(1933,1934,1935,1936,1936 a)$ and S. Yaмamoto (1941) in the ponds. near the seashore. In pursuit of the same line of study, small outlying islets. were also investigated, Yoshimura and Mryadr taking up Miyake-jima in 1936, Mashiko Hegura-jima in 1950, Mrzuno and Kosaka Tomoga-shima in 1955 and the expedition of the Osaka Municipal Natural History Museum the Sokonashi-ike pond in the Tokara Islands in 1955. The problem of wind-borne salt from the sea was taken up by Matsudaira (1937, 1937a), SugaWara (1948) and Iwasaki (1934), the relation between $\mathrm{SiO}_{2}$ and diatoms by Horasawa (1932) and Sugawara (1938), and more recently the problem of planktonic generation by KURASAWA (1958), HôGETSU et al. (1952) and Ichimura (1956). Ponds, however, were no direct. subject of study in these investigations.

Attention is now being paid to the exploitation of inland waters, leading to the study of fish-ponds and reservoirs constructed for electric generation or local water-supply service. Setting aside the artificially constructed lakes, fish-ponds, a form of exploitation of inland waters, are mainly studied from the view points of chemical conditions and planktonic fluctuations, since such ponds are directly related with the reproduction of fishes. Formerly, KanEChIKA (1931), H. WATANabe (1931), Ôshima (1931), S. Watanabe (1932) and Matsul and Ôshima (1934); and in the post-war days, HoJita $(1954,1955)$ and NaKaMUra et al. (1958) studied pisciculture carried on by means of ground-bait. D. INABA (1934), T. INABA (1937) and Iто (1955 1959) published their reports on what is called "waterchange" in the eel farming ponds utilizing brackish water. J. WATANABE (1957) took up for a subject of his study a particular kind of goldfish breeding ponds.

From the above brief historical view of the studies on ponds in this country, it must be said that, as compared with studies on lakes, those on ponds are still lagging far behind in their clarification of their characters as well as in the analysis of the principles of planktonic generation and metabolism.

\section{b) Studies in Foreig a Countries}

There is a tendency even in foreign countries more attention is paid to lakes than to ponds. Thienemann (1931), Naumann (1932) and Järnefelt (1952), by lake types, and Thummark (1945), Nygaard (1949), Lilleroth (1950) and Rawson (1956) by planktonic habitation, made attempts at lacustrine typology, but only large lakes were investigated.

With regard to ponds, Surtr (1924) investigated the small lakes and ponds in the Palisades Inter-state Park, Atrins and Harris (1924) the chemical conditions and planktonic organisms of ponds in England, EDpy (1934) numbers of small lakes and ponds in the U.S.A., and KREUTNER (1934) carp farming ponds for the quantitative analysis of plankton. 
In more recent years, WAWRICK $(1954,1955,1956)$ dealt with ponds in Austria, Bathege (1952, 1953, 1955) ponds in Germany, LAAKsonen (1956, 1957) ponds in the southern part of Finland, and Lund (1957) the Stocks Reservoir in England. WELCH $(1935,1952)$ spared a chapter of his text-book "Limnology" for the discussion of the characters of ponds, though restricted only to natural ponds. In the "Handbuch der Frischwasser- und Abwasser-Biologie", an attempt by LieBmanN (1958) at the classification of ponds on the basis of the characters of ponds pointed out by WeIManN is highly suggestive.

As will be seen from the above, ponds have not been studied as thoroughly as lakes even in Europe and America, but it must be admitted that studies on ponds in the countries abroad are more than on ponds in Japan.

\section{METHODS OF STUDY}

\section{a) Chemical Conditions}

Water-temperature, $\mathrm{pH}$ value and dissolved $\mathrm{O}_{2}$ content were measured in the field. The chemical analysis of pond-water was made as soon as possible in each case by employing samples brought back in polyethylene containers of $500 \mathrm{~m} l$ capacity. For the measurement of the vertical distribution of temperature and collection of water samples at each different layer, Eckмan's water-sampler fitted with a reverse thermometer was used. The analytical methods and appliances are as follows :

$\mathrm{pH}$ : WaLPole's colorimetry (SuzUKI's colorimeter).

$\mathrm{O}_{2}$ : WinkLeR's method.

$\mathrm{Cl}^{-}$: MoHL's Ag titration method.

$\mathrm{SiO}_{2}$ : DIÉNerT-Wandenbluke's method (Dubosq's colorimeter).

$\mathrm{PO}_{4} \equiv-\mathrm{P}:$ DentĠ̀s-AtKin's improved method.

$\mathrm{NO}_{3}{ }^{-}-\mathrm{N}$ : Tillmans-Sutthoff's method.

$\mathrm{NH}_{4}{ }^{+}-\mathrm{N}$ : Method improved on WinkLeR's.

$\mathrm{Ca}^{++}$: Oxalic acid precipitation method.

$\mathrm{SO}_{4}^{--}$: Colorimetry done directly with standard $\mathrm{K}_{2} \mathrm{CrO}_{4}$ solution (DubosQ's colorimeter).

$\mathrm{Fe}^{++}$: Colorimetry by employing potassium rhodanide.

$\mathrm{KMnO}_{4}$ consumption : Ordinary method of examination with COONa or $(\mathrm{COOH})_{2} \cdot 2 \mathrm{H}_{2} \mathrm{O}$.

$\mathrm{COONa}^{\mathrm{C}} \cdot 2 \mathrm{H}_{\varepsilon} \mathrm{O}$

\section{b) Plankton}

The collection of plankton was performed by three times hauling of a 15-mesh net $25 \mathrm{~cm}$ in diameter. The plankton organisms thus caught were put into glass vials and were kept after fixing them with formalin beforehand. Since the plankton organisms were qualitatively caught in different places, the water of each vial was stirred up well and the number of individuals in $1 \mathrm{~m} l$ of it was 
observed under a microscope. The results were divided into the following five classes :

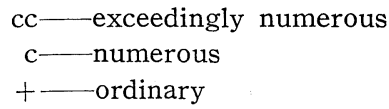

$\mathrm{r}-$ small in number
$\mathrm{rr}-$ very small in number

Sometimes ccc is used when the number is exceptionally great.

In making quantitative studies, the plankton organisms collected from the water surface by hauling the afore-mentioned plankton-net just once were employed. In this case, the number of individual organisms in $1 \mathrm{ml}$ of water was first counted on a $1 \mathrm{~mm}$ section slide-glass under a microscope, and then by numerical calculation, the value per $1 l$ of water was obtained. In investigating the vertical distribution of plankton, a handy plankton net for quantitative determination of KITAHARA's type was employed, and the whole number of individuals caught was counted. With regard to phytoplankton forming colonies, calculation was made by counting each colony as an individual. The numerical quantities were shown in graphic forms in accordance with Lohmans's "Kugelkurvenmethode".

Furthermore, glass vessels of $250 \mathrm{ml}$ capacity were made use of in the breeding experiments of plankton. The culture fluid used was mainly $200 \mathrm{~m} l$ of extraction of horses-dung after BANTA. The experiments of plankton recovering out of the bottom mud samples were performed by adding $200 \mathrm{ml}$ of distilled water to the scooped mud $1 \mathrm{~cm}$ thick so as to make the process of recovery observable. In scooping the mud, a $15 \mathrm{~cm} \times 15 \mathrm{~cm}$ EkMaN-BiRGE's dredge was used.

\section{THE DEFINITION AND DISTRIBUTION OF PONDS}

\section{THE CONCEPTION OF 'PONDS' AND THE DEFINITION OF 'TAMÉ-IKE' PONDS}

There is no doubt that the conception of a pond is different at least from that of a lake such as Lake Biwa or Lake Towada. But in making on the field investigations actually, no small difficulty is not seldom met with in deciding how to draw a line of distinction between a pond and a lake. There are ponds of various types, large and small, or deep and shallow. Some lakes are very small and others are so shallow that there is little or nothing to distinguish them from swamps. Most of the lakes of the latter type are actually called 'ike' or pond, which proves clearly how difficult it is to tell either pond or lake.

Accordingly, this necessitates the conceptual clarification of 'ponds' and the definition of 'tame-ike' ponds before proceeding further. In this connection, WeLCH $(1935,1952)$ mentioned three different types of ponds: (1) those which represent the pond stage in the extinction of previous existing lakes ; (2) those whose basins have never been large or deep (not preceded by a lake) but instead have been small of area from the start and, because of recent origin or for some special reason, have persisted in the pond stage; and (3) those whose basins 
are results of man's activities (excavations, quarries, impoundments, \&c.). Natural processes alone are constantly forming new pond basins (cutoffs from streams, solution basins, beach ponds and many others), some of which are never more than temporary ponds from the beginning; others qualifying as permanent ponds at least for a period in their existence. Aside from these, he further divided ponds into two categories, permanent and temporary, according to the duration of their water storage. WeLCH, however, admitted the difficulty of drawing a line of distinction between a lake and a pond.

UÉNo (1935) defined a pond as a water-basin or a pool capable of being drained off by means of some artificial device and was of the opinion that it could thus be distinguished from a swamp. Yoshimora (1937), on the other hand, considered a pond to be a lake or marsh of smaller size, including those constructed artificially either by excavating the ground or by damming up valleys, and he declared that a pond should thus be distinguished from either of a lake, a marsh or a swamp. By the former a pond was defined in a narrow sense, while by the latter, more importance was attached to those artificially constructed ones, not excepting, of course, the smaller water basins of natural origin. It is true that WeLCH's conception of a pond comprised a pool of water stored in quarries and gravel or clay pits of artificial origin, but since he did not touch the question of artificial drainage of pond-waters, he must have had in his mind a pond which the writer is going to take up as a natural pond.

In the present writer's view, what he calls a 'tame-ike' pond can be distinguished from a pond in its wide sense as follows. A 'tame-ike' pond is not a pond where water collects naturally, but a pond where water is stored artificially and where, more properly speaking, the volume of water can at any time be regulated. Accordingly, the writer's conception of a 'tame-ike' pond is far stricter and narrower than any definition of a pond hitherto proposed. Water-basins of natural origin are of course not comprised. In this sense, his conception in this connection comes very near to UENo's mentioned above.

Another question, however, arises. Can all those large scale reservoirs recently constructed either for electric generation or for city water-supply service be called 'tame-ike' ponds? In most cases, they are constructed by damming up the gorges in the upper reaches of large rivers, and although they are somewhat different from lakes because of their characters of rivers they still retain noticeably, they are decidedly more lakes than 'tame-ike' ponds, so far as hydrobiological studies are concerned, for they are incomparably greater than 'tame-ike' ponds both in surface area and in depth. They should rather be classed separately as artificially constructed lakes and be excluded from the category of 'tame-ike' ponds.

From all these considerations described above, it may now be defined that a 'tame-ike' pond is a pond of rather small depth and surface which is partly or wholly surround by an embankment and whose volume of water can be regulated by some artificial device.

The writer investigated these 'tame-ike' ponds mostly, together with a number 
Table 1. The conception of lakes and ponds, showing the position of 'tame-ike' ponds.

\begin{tabular}{|c|c|c|c|}
\hline $\begin{array}{c}\text { Area } \\
\text { Depth } \\
\text { Origin }\end{array}$ & $\begin{array}{l}\text { Small } \\
\text { Shallow }\end{array}$ & $\begin{array}{l}\text { Large } \\
\text { Deep }\end{array}$ & $\begin{array}{l}\text { Regulation } \\
\text { of water } \\
\text { volume }\end{array}$ \\
\hline \multirow[b]{2}{*}{ Natural } & Pond & $1 \mathrm{p}-$ Lake & \multirow[b]{2}{*}{ impossible } \\
\hline & $\begin{array}{l}\text { Hollow ground, crater, } \\
\text { ox-bow lake, subsidence, } \\
\text { beach pond, spring, bog, } \\
\text { naturally dammed-up basin, } \\
\text { solution basin, \&c. }\end{array}$ & $\begin{array}{l}\text { Depression lake, } \\
\text { sand-dune lake, } \\
\text { crater, lagoon, } \\
\text { naturally dammed-up } \\
\text { water basin }\end{array}$ & \\
\hline \multirow[b]{2}{*}{ Artificial } & 'Tame-ike' pond & \begin{tabular}{|c|} 
Artificially \\
constructed lake
\end{tabular} & \\
\hline & $\begin{array}{l}\text { Dammed-up valley, } \\
\text { embanked water basin, } \\
\text { dug-up water basin. }\end{array}$ & $\begin{array}{l}\text { Generating dam, } \\
\text { reservoir for water- } \\
\text { supply service. }\end{array}$ & possible \\
\hline
\end{tabular}

of natural ponds whose research data could be used for comparative studies. 'Tame-ike' ponds, originally intended for the irrigation of paddy fields, are a crowded in rice-field areas or near farming villages. They are chiefly exploited for irrigation, pisciculture, small-scale water-supply works (as at Tobi-shima in Yamagata prefecture) and electric generation (as at Amami-Ôshima in Kagoshima prefecture).

\section{THE DISTRIBUTION OF 'TAME-IKE' PONDS IN JAPAN AND THE AREAS COVERED BY THE WRITER'S INVESTIGATION}

The distribution of 'tame-ike' ponds is dependent upon the climatic and geological conditions as well as upon the factors of human necessity. Generally speaking, there is a tendency that they are found in great numbers in a plain or on its peripheral tableland or in a basin. But they are seldom found in areas where irrigation water is drawn directly from rivers and where there is much rainfall. The existence of so many 'tame-ike' ponds (to be called simply ponds hereafter) in the coastal districts of the Inland Sea can be accounted for by the fact that. because of deficient rainfall throughout the year these ponds have to depend solely upon ponds for irrigation water. In the coastal districts of the Japan Sea, too, there are many ponds of this kind, for although the yearly precipitation is pretty great there, much of it comes from heavy snowfalls in winter and summer is. the dry season. Such inland basins as Nara, Nagano, Matsumoto and Yamagata have few rivers, with little rainfall in summer, and ponds are naturally found in considerably large numbers in these basins. Rice cultivation is well developed 
on some of the outlying islands of this country, such as Sadoga-shima, Okinoshima and Nansei-shotô, and on these islands a good many ponds are found scattered. But other small islands, such as Rishiri-tô, Tobi-shima and Tomogashima are thinly populated and have no paddy fields for rice cultivation. Because of the particular geological formation of the islands, Izu-Miyake-jima, Hachijôjima and Amami-Ôshima have few except for a number of natural ponds.

Concerning the distribution of 'tame-ike' ponds, TAKEUCHI $(1939,1940)$ dealt with the relative size of ponds and the relations between such ponds and rice cultivation from the viewpoint of descriptive geography. With a view to clarifying the characters of ponds from the viewpoint of limnology, the writer investigated ; firstly, groups of ponds in the suburban areas of Osaka City each differing from the others in geological features for the comparative study of the chemical conditions of water and the composition of plankton communities; secondly, those ponds found profusely both in the coastal low-lying areas and on the coastal tablelands of the Inland Sea for the investigation of local homogeneity and heterogeneity concerning the chemical conditions of the pond waters and the composition of plankton communities ; thirdly, those ponds lying on the outlying islands and near the seashore for the verification of external effects of the sea upon them, taking up at the same time some ponds in the inland basins for comparison; fourthly, those ponds found in the peripheral parts of large cities, along with fish breeding ponds, for the clarification of their characters in connection with the fact that although eutrophic naturally, these ponds were often found contamination by ground bait, residue from drain systems and foul water from factories. The chief spots of investigation are listed below (See Fig. 1).

1) Groups of Ponds in the Northern Areas of Osaka
a. the alluvial area
b. the diluvial tableland
c. the mountainous part of palaeozoic strata
d. the mountainous part of granitic strata

2) Groups of Ponds in the Coastal Districts of the Inland Sea

a. the southern part of Osaka pref.

b. Tsuchiyama in Hyôgo pref.

c. Hôjô in Hyôgo pref.

d. Kiyone in Okayama pref.

e. Kamogata in Okayama pref.

f. Saijô in Hiroshima pref.

g. Matsuyama in Ehime pref.

h. Marugame in Kagawa pref.

i. Takamatsu in Kagawa pref.

j. other areas

3) Groups of Ponds on the coast of the Japan Sea and the outlying Islands
a. Sadoga-shima
b. Okino-shima
c. Rishiri-tô
d. Tobi-shima
e. Miyake-jima
f. Hachijô-jima 


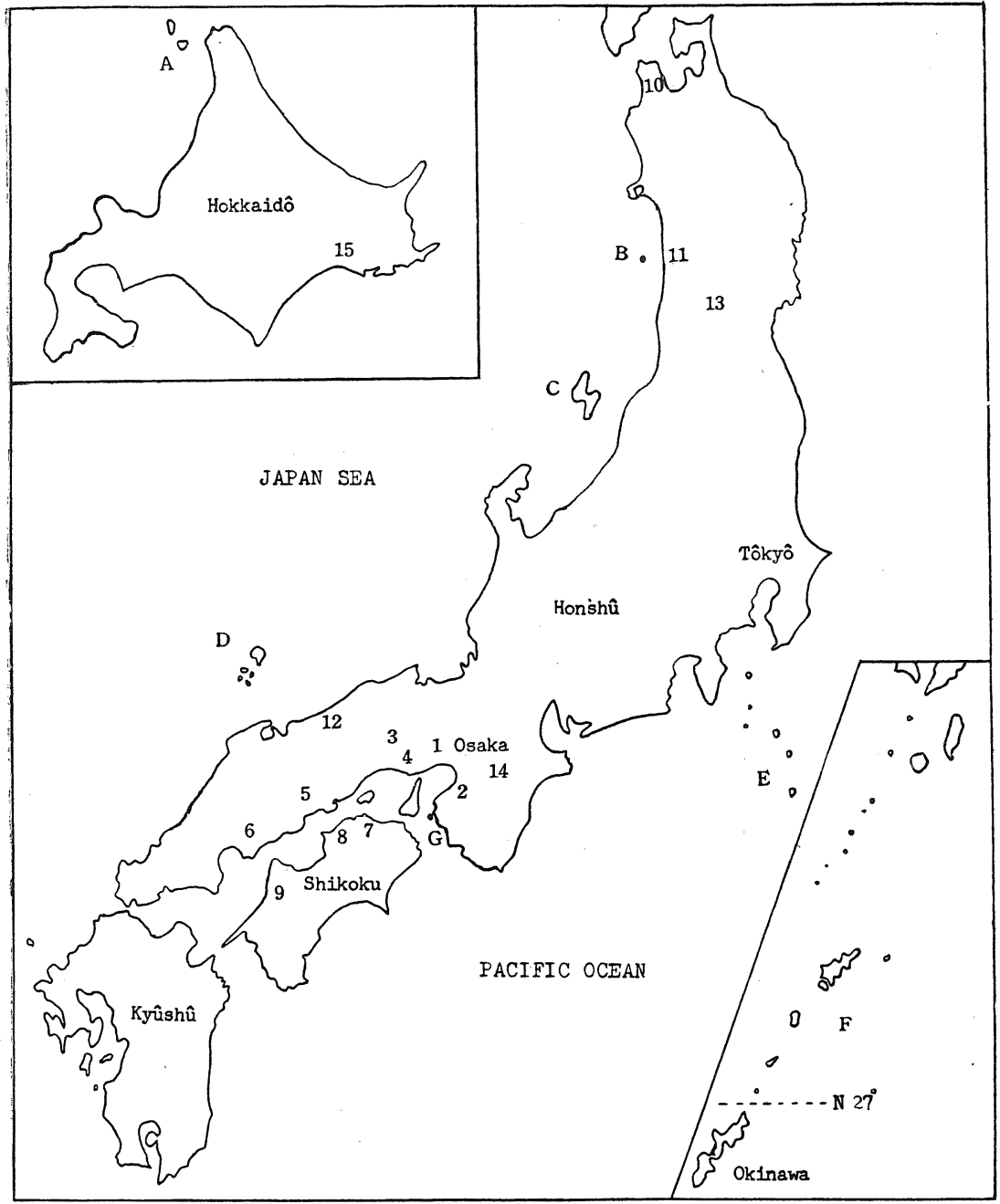

Fig. 1 Map showing the location of the freshwater ponds investigated.

1. Northern part of Osaka, 2. Southern part of Osaka, 3. Hôjô, Hyôgo pref., 4. Tsuchiyama, Hyôgo pref., 5. Kamogata and Kiyone, Okayama pref., 6. Saijô, Hiroshima pref., 7. Takamatsu, Kagawa pref., 8. Marugame, Kagawa pref., 9. Matsuyama, Ehime pref., 10. Tsugaru, Aomori pref., 11. Kisagata, Akita pref., 12. Tottori Sand-dune, 13. Western part of Yamagata pref., 14. Kôriyama, Nara pref., 15. Kushiro City

A. Rishiri-tô Island, B. Tobi-shima Island, C. Sadoga-shima Island, D. Okino-shima Islands, E. Izu-shotô Islands, F. Nansei-shotô Islands, G. Tomoga-shima Islands. 

g. Amami-Ôshima
h. Okinoerabu-jima i. Yoron-tô
j. Tomoga-shima
k. the coastal area of Tottori pref.
1. Kisagata coastal area of Akita pref.
m. Tsugaru area in Aomori pref.

4) Groups of Ponds in the Inland Basins
a. Yamagata Basin
b. Nara Basin

5) Ponds in Big Cities and Fish Breeding Ponds

a. Osaka City and Amagasaki City

b. goldfish breeding ponds at Kôriyama

c. other places

Aside from the spots of investigation listed above, the writer also selected the following ponds of various types to observe both the diurnal and the seasonal fluctuations of chemical conditions and plankton communities.

1) Diurnal Fluctuations

a. Pond No. 202 at Kôyôen (oligotrophic)

b. Chausuyama-ike pond in Osaka City (eutrophic)

c. Shimo-ike pond at Itami City (mesotrophic)

2) Long-continued Seasonal Fluctuations

a. Shimo-ike pond at Itami City

b. Tsujiga ike pond in Ikeda City

\section{THE COMPARATIVE STUDIES OF REGIONAL POND GROUPS}

\section{POND GROUPS IN THE SUBURBS OF OSAKA CITY}

The pond groups around Osaka City will be geologically divided into four different formations, alluvial, diluvial, palaeozoic and granitic. The ponds on the diluvial tableland are further subdivided into three groups by the intensity of contamination caused by sewage from many dwelling houses springing up in rapid succession in recent years. Ponds Nos. 81,82 and 85 belonging to the Group A are located on the western slope of Mt. Shimakuma in Toyonaka City and are surrounded with pinetrees and clumps of shrubs, with no dwelling-house in its neighbourhood. There are three ponds filled with clear and whitish water, and no water-plants except Potamogeton are found in them. Around the Group B (ponds Nos. 94, 119 and 114) lying in the southern part of the same tableland there are a number of dwelling-houses, from which contaminated water flows into the ponds in some slight degree.

The ponds are covered with an association consisting of Hydrilla verticillata, Nymphaena tetragona var. angusta, Euryale felox, Trapa natans var. quadrispinosa and others. Ponds Nos. 1,2 and 3 belonging to the group $\mathrm{C}$ found on the western periphery of the same tableland are considerably contaminated not only by sewage but by dust and dirt thrown, no aquatic plants growing. Pond No. 198 
on the alluvial plain has on its surrounding shore the association, consisting of Phragmitis communis and Zizania latifolia, both of which are gradually invading toward the central part, transforming into a marsh. The water-surface is covered with Salvinia natans, Azolla japonica, Lemna minor, \&c. In the neighbourhood of the pond there is no dwelling-house, but it borders on the paddy fields. The water-depth is small and the bottom is covered with thick mud, which is black and rich in organic matter. Ponds Nos. 200 and 201 are on the palaeozoic formation, ponds Nos. 202 and 203 lie on the granitic formations at the southeastern foot of Mt. Rokkô. Both pond groups are filled with clear water and blue, tinged with a slightly whitish colour, without aquatic plants at all. The bottoms of the former pond-group are covered with reddish brown clay and those of the latter mostly with granitic sand.

\section{a) Physical and Chemical Conditions}

Water temperature : The water temperature of the Group A ponds both on the diluvial tableland and on the palaeozoic formation are lower than that of the ponds belonging to the other groups, because they are naturally dammed-up ponds situated in mountainous areas. Therefore, cold subterranean water wells out of the ground. The temperature of the surface-water of the ponds belonging to the granitic formation is higher, probably because the radiant heat given off by the shore-rock is considerable when the measurement is made on the shore. The depth of the ponds in the alluvial plain is smaller, but the temperature is lower, because all over the water-surface is covered with duckweed.

pH : The ponds on the granitic formation has a mean $\mathrm{pH}$ value of 5.75 , those on the palaeozoic formation 6.2, the Group A ponds on the diluvium 6.45, the Group $\mathrm{B}$ ponds 6.68 and the Group $\mathrm{C}$ ponds 7.23 . It may be considered, therefore, that more contamination results in a higher $\mathrm{pH}$ value. In the case of pond No. 1 in which contamination is most conspicuous, the $\mathrm{pH}$ value is found to be 8.0. Having been rich in humus and covered all over with duckweed, pond No. 198 on the alluvial plain shows slight acidity.

Dissolved $\mathbf{O}_{2}$ : There is approximately no dissolved $\mathrm{O}_{2}$ content in pond No. 198 on the alluvium, but the Group $\mathrm{C}$ ponds on the diluvium indicate an over-saturation of $200 \%$ or more strongly affected by contamination due to domestic drainage. This may be attributable to the photosynthesis of phytoplankton at the upper layer of them. On the other hand, the $\mathrm{O}_{2}$ deficit in pond No. 198 on the alluvium arises chiefly from the consumption of the organic substance contained in the bottom deposits; there are therefore only a small number of zooplankton present in the pond.

In spite of the geological differences of the surrounding areas, the Group A ponds on the diluvium and those on the palaeozoic as well as granitic formations are closely similar to each other in the average contents of dissolved substances. The consumption of $\mathrm{KMnO}_{4}$ is only in higher in the Group A ponds than in the others. When the three different pond groups $\mathrm{A}, \mathrm{B}$ and $\mathrm{C}$ are compared, it is 
Table 2. Physical and chemical conditions of the pond waters of the (W. T. ${ }^{\circ} \mathrm{C} ; \mathrm{O}_{2} \mathrm{cc} / l, \mathrm{O}_{2}{ }^{\prime} \%$; dissolved substances, $\mathrm{mg} / l$ )

\begin{tabular}{|c|c|c|c|c|c|c|}
\hline Ponds & Date & W.T. & $\mathrm{pH}$ & $\mathrm{O}_{2}$ & $\mathrm{O}_{2}^{\prime}$ & $\mathrm{Cl}$ \\
\hline Granitic & VII-VIII & 30.2 & 5.75 & 6.2 & 116.5 & 6.8 \\
\hline Palaeozoic & $\prime \prime$ & 27.9 & 6.2 & 6.2 & 115. 3 & 6. 0 \\
\hline Diluvium A & " & 29.0 & 6.5 & 6.4 & 111. 1 & 7.0 \\
\hline B & " & 32.0 & 6. 68 & 5.9 & 114.7 & 16. 3 \\
\hline $\mathrm{C}$ & " & 32.1 & 7. 23 & 11. 7 & 227.6 & 32.8 \\
\hline Alluvium & $\prime \prime$ & 29.1 & 6.2 & 0.3 & 0.5 & 23.5 \\
\hline
\end{tabular}

found that more contamination causes an increase of constituents such as $\mathrm{Cl}^{-}$, $\mathrm{SO}_{4}=, \mathrm{Ca}^{++}, \mathrm{PO}_{4} \equiv, \mathrm{NH}_{4}^{+}, \mathrm{NO}_{3}^{-}$, \&c. This suggests that in such cases due to sewage the contents of such constituents may possibly be an index of the degree of contamination. The amount of $\mathrm{KMnO}_{4}$ consumption in pond No. 198 on the

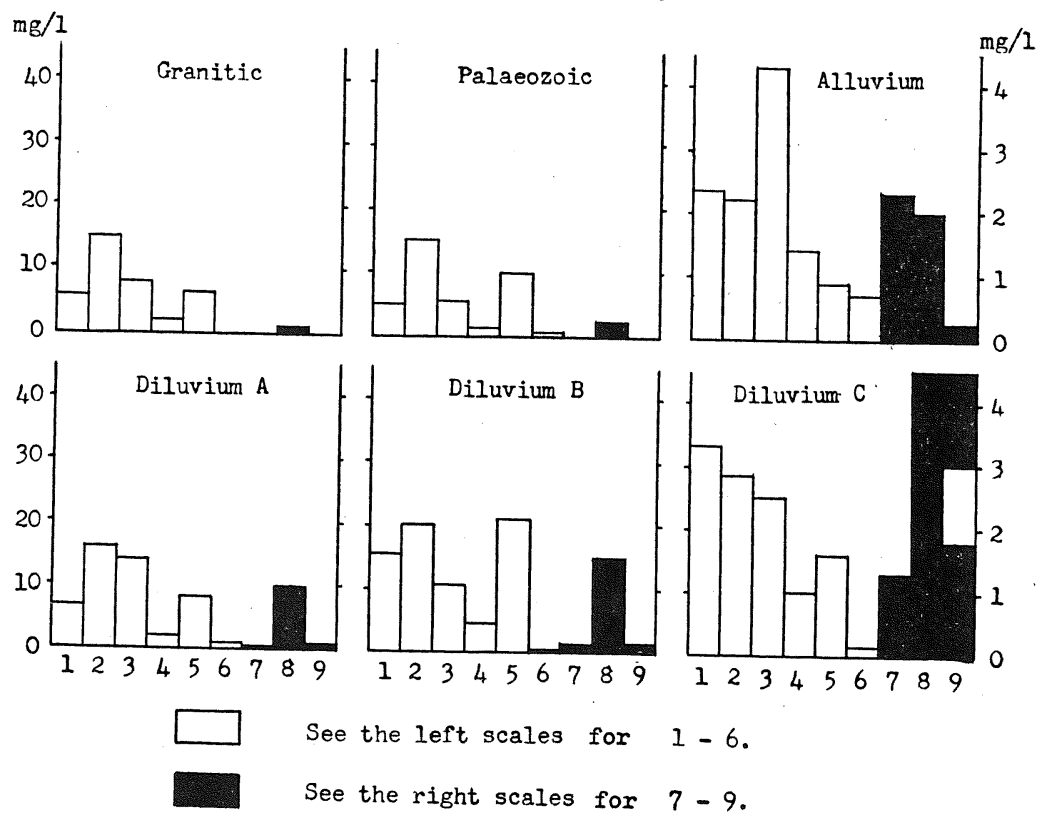

Fig. 2. Comparison of the dissolved substances in the pond-waters in the northern part of Osaka (geological difference and contamination).

1. Cl-ion 2. $\mathrm{SO}_{4}$-ion 3. Consumption of $\mathrm{KMnO}_{4}$ 4. $\mathrm{Ca}$-ion

5. $\mathrm{SiO}_{2}$ 6. Fe-ion 7. $\mathrm{PO}_{4}-\mathrm{P}$ 8. $\mathrm{NH}_{4}-\mathrm{N}$ 9. $\mathrm{NO}_{3}-\mathrm{N}$ 
different geological areas (mean values), (1950).

\begin{tabular}{|c|c|c|c|c|c|c|c}
\hline $\mathrm{SO}_{4}$ & $\mathrm{KMnO}_{4}$ & $\mathrm{Ca}$ & $\mathrm{SiO}_{2}$ & $\mathrm{Fe}$ & $\mathrm{PO}_{4}-\mathrm{P}$ & $\mathrm{NH}_{4}-\mathrm{N}$ & $\mathrm{NO}_{3}-\mathrm{N}$ \\
\hline 15.0 & 8.25 & 2.45 & 6.4 & 0.18 & 0.005 & 0.1 & 0.01 \\
14.7 & 5.55 & 2.11 & 10.25 & 0.5 & 0.005 & 0.02 & 0.01 \\
16.3 & 8.5 & 2.19 & 8.6 & 1.4 & 0.09 & 1.7 & 0.05 \\
20.1 & 11.1 & 4.05 & 5.9 & 0.5 & 0.01 & 2.2 & 0.38 \\
28.5 & 24.3 & 9.46 & 16.1 & 0.63 & 1.25 & 6.03 & 1.73 \\
22.3 & 38.5 & 13.70 & 8.7 & 7.3 & 2.3 & 2.0 & 0.20 \\
\hline
\end{tabular}

alluvium is remarkably large. This dug-up pond has been called 'fuke' or sterile area from early days and is gradually turning into a marsh. The pond may be said to be a representative one of a dystrophic type, besides being of an eutrophic type.

It may be seen from the above-stated results that, so far as the writer's measurements are concerned, geological differences have little or no effect upon the dissolved chemical components, even if some slight effect upon them may not be absolutely denied. The more important factor capable of affecting the chemical conditions of the pond-waters is the intensity of contamination due to domestic drainage rather than to the geological differences of the surrounding: areas.

\section{b) Plankton Communities in Each Group of Ponds}

The summer (July and August) plankton community of each pond group was: studied comparatively and in particular its member-species and the volume. Figs. 3 and 4 show the number of individual plankton organisms per liter of water which was obtained by numerical calculation from the microscopic examination of the water samples collected by means of a plankton-net.

Pond No. 198 on the alluvium : One meter deep, dark brownish, covered with aquatic plants and rich in dissolved substances and organic matter. Dissolved $\mathrm{O}_{2}$ is absent. However, there can be found no species of zooplankton other than Asplanchna priodonta and two other species in small quantities. Difflugia, Euglena, Phacus, \&c. belonging to Protozoa are found somewhat abundantly and phytoplankton species such as Oscillatoria, Fragilaria, Navicula, Synedra, \&c. occur only scantily. In spite of an eutrophic type, this pond is remarkably limited in the number and volume of plankton organisms.

Group A on the diluvium : Blue but somewhat whitish in colour, with Potamogeton growing scantily. The three ponds are rather poor in dissolved substances, but have fairly numerous species of plankton animals such as Keratella cochlearis, Euchlanis dilatata, Monostyla quadridentata, Asplanchna priodonta, Polyarthra trigla, Mesocyclops leuckarti, Alona guttata, Moina macrocopa, Bosminopsis deitersi, 


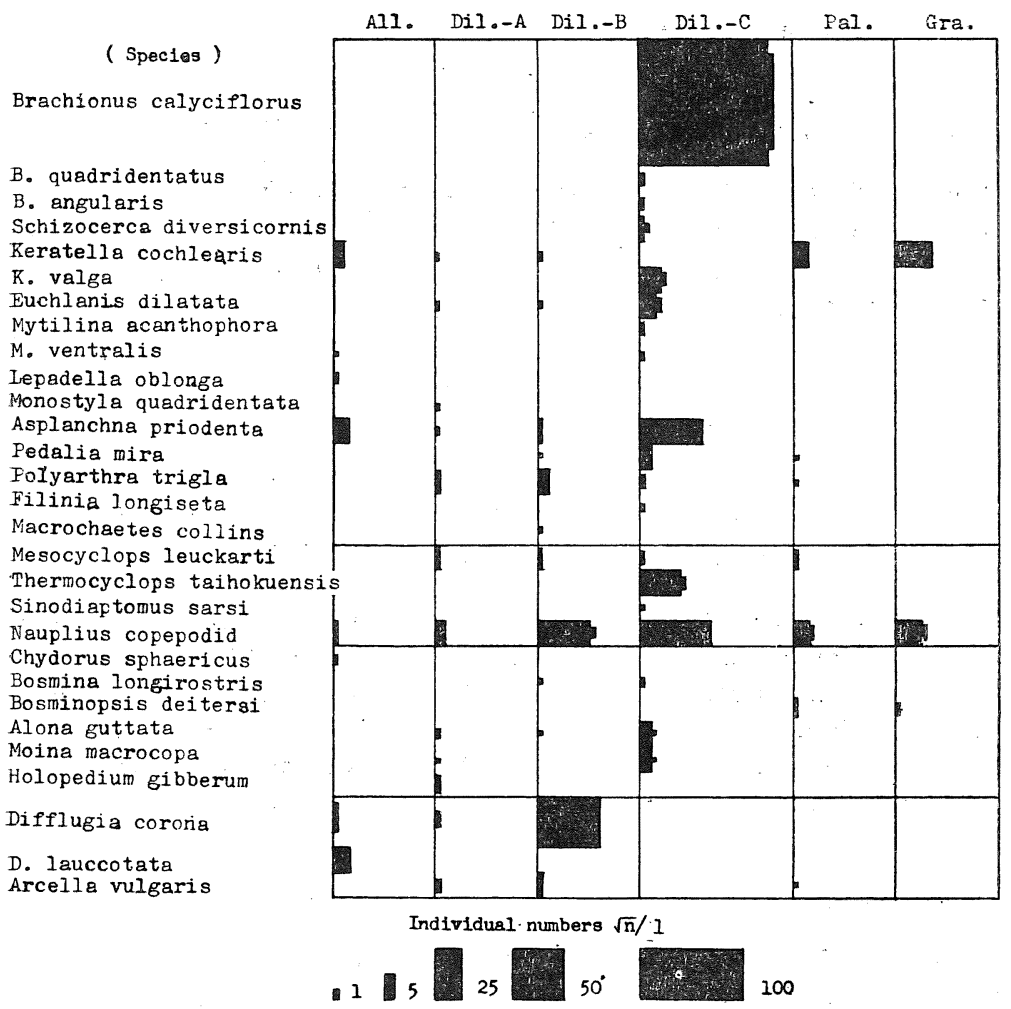

Fig. 3. The species and the number of their indivividuals $(\sqrt{\mathrm{n}} / l)$ of the principal zooplanktonts occurred in the pond groups of the defferent geological areas.

All. : Alluvium, Dil.-A : Diluvium A, Dil.-B : Diluvium B, Dil.-C: Diluvium C, Pal. : Palaeozoic, Gra.: Granitic

and lastly Holopedium gibberum, a rare species in this district, though individuals very limited in number. Among the species of phytoplankton there occur such diatom species as Melosira italica, Cymbella affinis and Synedra ulna, two species of Staurastrum, and one species of Euastrum, Closterium, Cosmarium, Desmidium, Xanthidium and Triploceras respectively. All of them are usually found in ponds of an oligotrophic type.

Group B on the diluvium: As compared with the Group A, there are found more species of plankton organisms in larger individual numbers. Under the influence of advanced contamination due to domestic drainage, the dominant species are Asplanchna priodonta, Polyarthra trigla and Pedalia mira. No less 


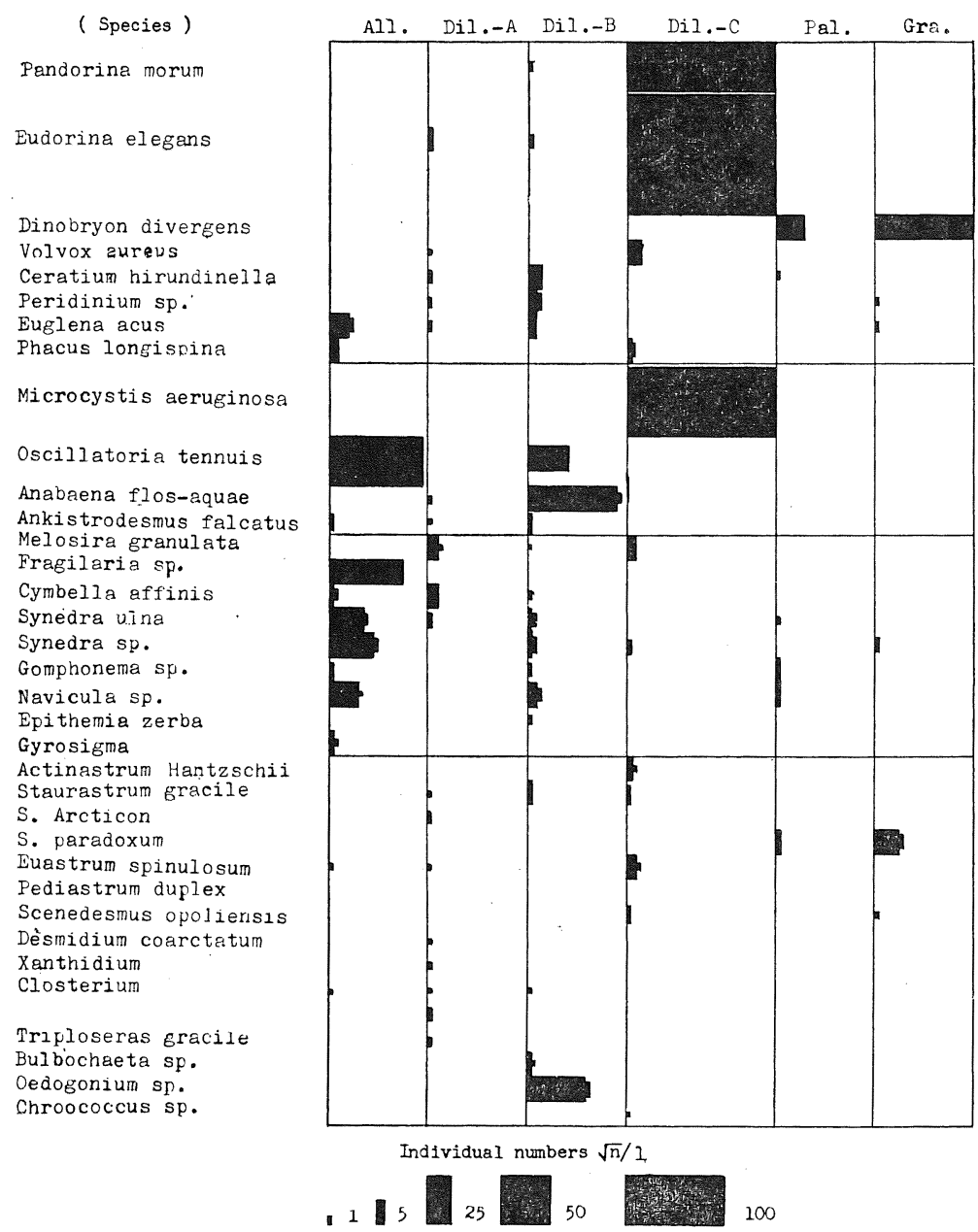

Fig. 4. The species and the number of their individuals $(\sqrt{\mathrm{n}} / l)$ of the principal phytoplanktonts occurred in the pond-groups of the different geological areas.

All. : Alluvium, Dil.-A : Diluvium A, Dil.-B : Diluvium B, Dil.-C : Diluvium C, Pal. : Palaeozoic, Gra. : Granitic

dominant are Protozoa such as Diffugia corona, Euglena viridis, Ceratium hirundinella, Arcella vulgaris and Peridinium cinctum, and algae such as Oscillatoria, Anabaena and Ankistrodesmus. Both Chlorophyta and Bacillariophyta are found 
scantily in mixed existence with all the species mentioned above.

Group $\mathbf{C}$ on the diluvium : The ponds belonging to this group are much polluted both by an inflow of sewage and by dirt and dust. The color of water is dark green or dark brownish, without aquatic plants appearing on the water-surface. Among the zooplankton, some species belonging to Brachionus are predominant, Keratella valga, Euchlanis dilatata, Asplanchna priodonta and others following them in considerable abundance. Thermocyclops (Copepoda), Moina macrocopa and Alona guttata (both Cladocera) and Protozoa such as Pandorina morum and Eudorina elegans are found in plenty. Microcystis aeruginosa belonging to Myxophyta forms a 'water-bloom', which is a good proof for these ponds as an eutrophic type.

Pond groups on both formations, palaeozoic and granitic: Both the pond groups are not only geologically different but also located far apart. They are, however, very similar in regard to their chemical conditions and plankton communities. In the ponds on the palaeozoic formation Staurastrum paradoxum is the predominant species, Dinobryon divergens and Keratella cochlearis following it. The dominant species in the ponds on the granitic formation is Dinobryon divergens, Keratella cochlearis and Staurastrum paradoxum coming next to it. These ponds of both groups are naturally dammed-up ponds in valleys and are quite free from any kind of contamination, so that there are found no blue-green algae at all. Besides, green algae and diatoms can hardly be seen. Table 3 shows the mean volume of plankton per liter of water numerically calculated from the average number of individual organisms observed by microscopic examination.

Table 3. Number of individuals occurring in the ponds of the different geological areas $(\mathrm{n} / l)$.

\begin{tabular}{|c|c|c|c|c|c|c|}
\hline & \multirow{2}{*}{ Alluvium } & \multicolumn{3}{|c|}{ Diluvium } & \multirow{2}{*}{ Palaeozoic } & \multirow{2}{*}{ Granitic } \\
\hline & & A & B & $\mathrm{C}$ & & \\
\hline Rotifera $\ldots \ldots \ldots \ldots$ & 100.5 & 30.5 & 39.7 & 1468. 3 & 51.8 & 108.0 \\
\hline Copepoda....... & 34.5 & 26.5 & 109.5 & 242.8 & 60.0 & 84.0 \\
\hline Cladocera.... & 10.5 & 5.0 & 3. 0 & 48. 0 & 7.0 & 7.5 \\
\hline Protozoa ............. & 310.5 & 41.5 & 353.7 & 2163.5 & 570.0 & 24.4 .0 \\
\hline Myxophyta......... & 1165.5 & 3.0 & 268.5 & 801.6 & 0 & 0 \\
\hline Bacillariophyta.. & 1256.5 & 48.0 & 79.5 & 25.0 & 33.0 & 72.5 \\
\hline Chlorophyta..... & 31.5 & 22.5 & 148. 0 & 153. 0 & 176. 0 & 87.0 \\
\hline Total & 2909.0 & 176.5 & 1000.9 & 4902.2 & 897.8 & 603.8 \\
\hline
\end{tabular}

c) The Relation between Chemical Conditions and Plankton

From the above-stated results of the investigations of the ponds around Osaka, it is known that both chemical conditions and plankton are affected not so much 
by the chemical components of pond waters as by the contamination due to domestic drainage, so far as these ponds are concerned. As will be seen from Figs. 3. and 4 , both the dominant species and their individuals vary remarkably according to the intensity of the contamination of the ponds in which they occur. The chemical conditions of the pond waters show in their relation to the plankton communities that some species have particular habitats of their own. For instance, desmids occur in the pond groups on both formations, palaeozoic and granitic, and also in the Group A ponds on the diluvium where the content of nutritive salts is scanty, but in all these ponds no blue-green algae occur. The blue-green algae and Protozoa are predominant both in the ponds on the alluvium and in the Group $\mathrm{C}$ ponds on the diluvium. What is more characteristic of these ponds is that in the former ponds the habitation of zooplankton is prevented by dissolved $\mathrm{O}_{2}$ deficit, while in the latter Brachionus is found in considerable abundance. It may safely be inferred that the amount of planktonic reproduction is under the influence of the content of nutritive substances. Holopedium gibberum, which has hitherto been known to occur only in waters poor in $\mathrm{Ca}^{++}$, appears in ponds Nos. 81 and 82 of the Group A on the diluvium where the content of $\mathrm{Ca}^{++}$ranges from 2.0 to $2.7 \mathrm{mg} /$. Oscillatoria Kawamurae, a large blue-green alga, first described in Manchurian inland waters, abounds in pond No. 8 (contaminated as slightly as the Group B ponds on the diluvium) so much as to form "water-bloom". Considered from the viewpoint of its distribution, this is quite a matter of interest.

\section{POND GROUPS ON THE COASTS OF THE INLAND SEA}

The plains on the coast of the Inland Sea are extensively occupied by paddy fields, which must depend upon irrigation reservoirs for water, as the yearly regional precipitation is very poor. This region, therefore, has the highest density of distribution of ponds in Japan, so far as irrigation reservoirs are concerned. Most of them are distributed either in the alluvial low-lying lands or on the diluvial tablelands, of which the coastal plains are composed. The representative ponds were selected from Osaka, Hyôgo, Okayama, Hiroshima, Ehime and Kagawa prefectures respectively. The areas such as Tsuchiyama in Hyôgo pref., Kamogata in Okayama pref., Takamatsu and Marugame in Kagawa pref. are of alluvial formation, and the ponds in these areas are mostly embanked, having either a circular or a square shape. On the contrary, the rest of the pond groups are found on the diluvial tablelands, most of them being semiartificial ones constructed by damming-up eroded valleys. Like the ponds in the northern part of Osaka, most of these ponds are free from contamination, with few or no dwelling houses in their neighbourhood, saving for patches of ground under cultivation in some cases. These ponds, with an exception of pond No. 1 in the Tsuchiyama area, have resemblances in their characters. Accordingly, comparative studies of pond groups are here made by taking into consideration the homogenous factors that can be found to constitute their distinctive features. 


\section{a) Physical and Chemical Conditions of Each Pond Group}

It is possible to divide the pond groups roughly into two classes-those on the alluvium and those on the diluvium. Between these two, distinctive features can be recognized, even when it is considered that investigations were conducted under different dates in some cases.

Water temperature : The water temperature of the surface-water varies according to the weather and the time of the day when measurement is performed, but by taking an average of the results obtained at the same period of time, it is found that the temperature of the pond groups on the alluvium is higher than that of the pond groups on the diluvium. In this connection, however, the pond group in Matsuyama, Ehime pref. is an exception. In spite of being situated on the diluvium, the water temperature of this pond group is higher than those of the other pond groups. This is because the ponds belonging to this group are exceptionally rich both in the content of dissolved substances and in the volume of plankton, in considering that they lie on the diluvium.

pH : Except for the Matsuyama area, it is possible to find differences of $\mathrm{pH}$ values between both the alluvial and diluvial pond groups. The former tends to be from neutral to alkaline even in late autumn, while the latter shows a tendency toward slight acidity. In Fig. 5 are given diagrams showing the content of each dissolved substance, which is the mean value in relation to the pond group of each area.

Table 4. The mean values of chemical analyses of the water of the ponds on

\begin{tabular}{|c|c|c|c|c|c|c|}
\hline & Name of locality & Date & W.T. & $\mathrm{pH}$ & $\mathrm{Cl}$ & $\mathrm{SO}_{4}$ \\
\hline \multirow{5}{*}{ 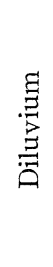 } & Sennan, Osaka & VIII & 31.3 & 6.78 & 6.9 & 15.04 \\
\hline & Hôjô, Hyôgo & XI & 11.4 & 6.65 & 6.5 & 6.97 \\
\hline & Kiyone, Okayama & $\prime \prime$ & 12.3 & 6.8 & 15.8 & 10.1 \\
\hline & Saijô, Hiroshima & $" 1$ & 11.5 & 6.6 & 9.4 & 8.6 \\
\hline & Matsuyama, Ehime & $" 1$ & 18. 6 & 7.45 & 8.5 & 17.8 \\
\hline \multirow{5}{*}{ 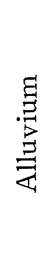 } & Sennan, Osaka & VIII & 29.4 & 7.3 & 15. 2 & 19.7 \\
\hline & Tsuchiyama, Hyôgo & $\mathrm{XI}$ & 17.0 & 7. 0 & 31.6 & 17.1 \\
\hline & Kamogata, Okayama & $\prime \prime$ & 11.5 & 7.1 & 24.0 & 23.0 \\
\hline & Takamatsu, Kagawa & $\prime \prime$ & 14.9 & 7.4 & 17.6 & 21.1 \\
\hline & Marugame, Kagawa & $\prime \prime$ & 16.3 & 7.3 & 12.3 & 27.4 \\
\hline
\end{tabular}


Cl-ion : $\mathrm{Cl}^{-}$in the ponds on the alluvium ranges from 13 to $28 \mathrm{mg} / \mathrm{l}$; the pond group in the Tsuchiyama area which lies close to the seashore shows the largest content. Among the pond groups on the diluvium, the group of the Kiyone area in Okayama pref. indicates a maximum of $12 \mathrm{mg} / \mathrm{l}$, while the content falls below $10 \mathrm{mg} / l$ in all the other pond groups. It follows, therefore, that $\mathrm{Cl}^{-}$content is larger in the embanked alluvial pond groups with no inflow of water than in the diluvial pond groups with more or less inflow of water from the surrounding area. This may possibly be due to the effect of sea-breeze, because of the proximity of the ponds to the sea. The question will be explained more in detail later, when the pond groups on the islands and in areas on the coast of the Japan Sea are dealt with.

$\mathrm{SO}_{4}$-ion: As in the case of $\mathrm{Cl}^{-}, \mathrm{SO}_{4}=$ content is much larger in the alluvial pond groups than in the pond groups on the diluvial tablelands. The mean value of $\mathrm{SO}_{4}=$ content in the former ranges from 18 to $27 \mathrm{mg} / l$, and in the latter from 7 to $13 \mathrm{mg} / l$. This may be considered to be due partly to the effect of seabreeze, too, but since there are some regional differences in this connection regardless of how far these ponds are from the seashore, there may possibly be another factor, namely, that of soil.

$\mathrm{KMnO}_{4}$ consumption : As a general rule, this is larger in the pond groups rich in nutrients on the alluvium than in the other pond groups. With the exception of the pond group in the Tsuchiyama area, Hyôgo pref., where the mean value in this connection is $10 \mathrm{mg} / l$ and slightly lower in comparison; $18 \sim 30 \mathrm{mg} / l$ is

the coasts of the Inland Sea, $(1951 \sim 1955)$. (W. T. ${ }^{\circ} \mathrm{C}$, dissolved substances, $\mathrm{mg} / \mathrm{l}$ )

\begin{tabular}{|c|c|c|c|c|c|c}
\hline $\mathrm{KMnO}_{4}$ & $\mathrm{Ca}$ & $\mathrm{SiO}_{2}$ & $\mathrm{Fe}$ & $\mathrm{PO}_{4}-\mathrm{P}$ & $\mathrm{NH}_{4}-\mathrm{N}$ & $\mathrm{NO}_{3}-\mathrm{N}$ \\
\hline 12.7 & 6.43 & 4.84 & 1.07 & 0.02 & 0.05 & 0.006 \\
9.9 & 21.4 & 4.38 & 0.40 & 0.02 & 0.23 & - \\
19.0 & 22.7 & 12.5 & 1.2 & 0.0 & 0.20 & 0.10 \\
14.7 & 27.9 & 6.6 & 0.5 & + & 0.24 & 0.15 \\
11.2 & 23.8 & 9.04 & 0.02 & 0.05 & 2.28 & - \\
30.5 & 22.5 & 3.5 & 2.3 & 0.85 & 1.12 & 0.029 \\
8.6 & 37.0 & 4.0 & 0.65 & 0.20 & 0.1 & 0.33 \\
21.9 & 35.8 & 6.3 & 1.25 & 0.017 & 0.32 & 1.20 \\
18.2 & 31.8 & 10.1 & 4.0 & 0.13 & 1.37 & 0.38 \\
19.9 & 38.9 & 7.5 & 4.48 & 0.31 & 0.7 & - \\
\hline
\end{tabular}



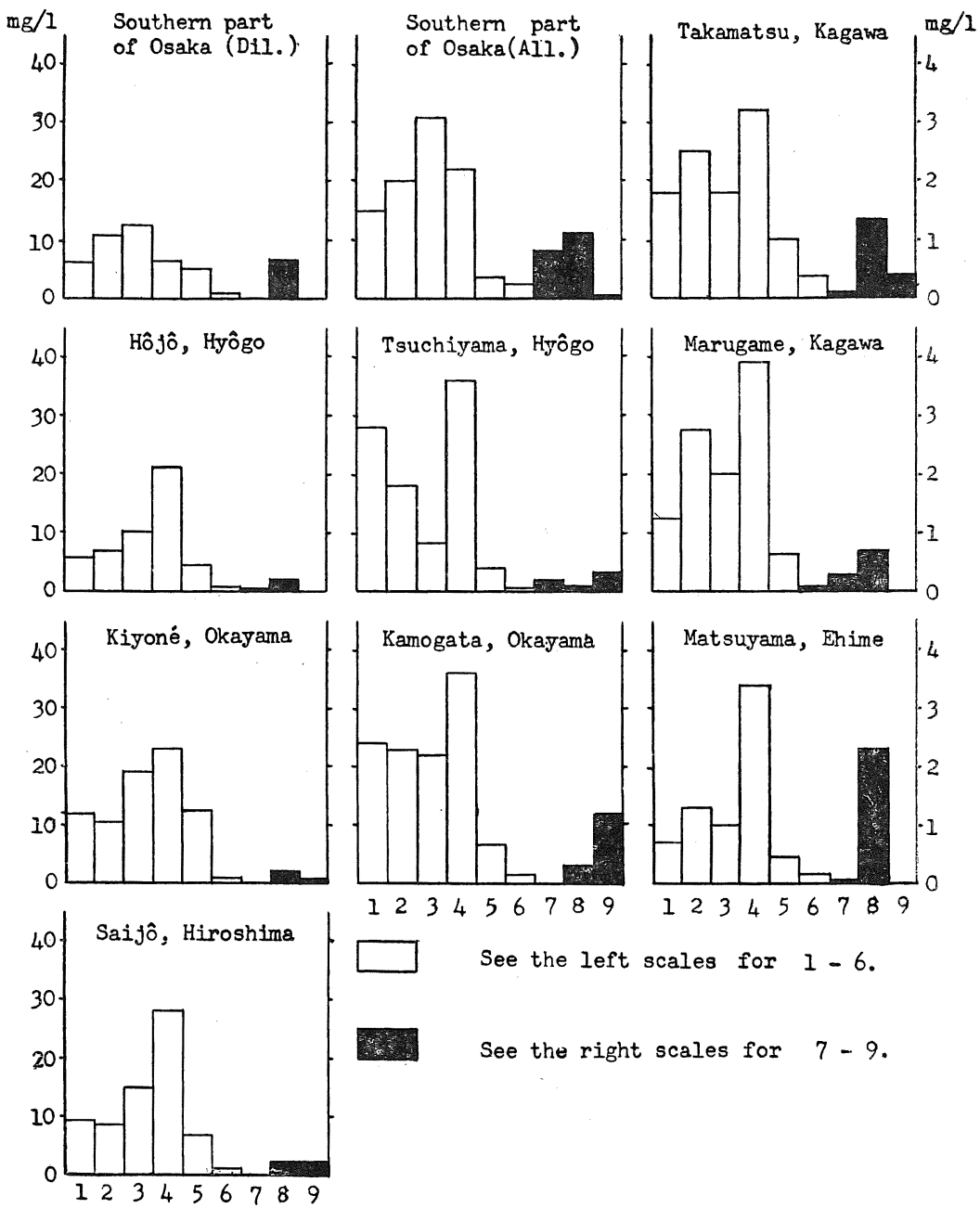

Fig. 5. A comparison of the dissolved substances in the pond groups on the coast of the Inland Sea.

1. Cl-ion, 2. $\mathrm{SO}_{4}$-ion, 3. Consumption of $\mathrm{KMnO}_{4}$, 4. Ca-ion, 5. $\mathrm{SiO}_{2}$, 6. Fe-ion, 7. $\mathrm{PO}_{4}-\mathrm{P}$, 8. $\mathrm{NH}_{4}-\mathrm{N}$, 9. $\mathrm{NO}_{3}-\mathrm{N}$ 
the range of consumption in most of these alluvial ponds. The consumption ranges from 10 to $19 \mathrm{mg} / \mathrm{l}$ in the pond groups on the diluvium, the pond group in Kiyone, Okayama pref. showing the maximum value.

Ca-ion: There is a tendency that $\mathrm{Ca}^{++}$content is likewise larger in the pond groups on the alluvium than in those on the diluvial tablelands, but in this connection regional differences are rather remarliable. In most of the alluvial pond groups, $\mathrm{Ca}^{++}$content exceeds $30 \mathrm{mg} / l$ with the exception of the group in the Sennan area, Osaka pref., in which $22 \mathrm{mg} / l$ is the minimum in the measured value. As for the pond group on the diluvial tablelands, $6.5 \mathrm{mg} / \mathrm{l}$ in the pond group on the Sennan tableland in Osaka pref. is a conspicuously low value. 20 $30 \mathrm{mg} / \mathrm{l}$ are the measured values of $\mathrm{Ca}^{++}$content of the pond groups at the Hôjô area, Hyôgo pref., the Kiyone area, Okayama pref. and the Saijô area, Hiroshima pref., with the maximum of $33.5 \mathrm{mg} / \mathrm{l}$ in the pond group in Matsuyama, Ehime pref. From these findings, $\mathrm{Ca}^{++}$content may be considered to be affected by geological differences in a considerable degree.

$\mathrm{SiO}_{2}: 12.5 \mathrm{mg} / \mathrm{l}$ in the pond group in Kiyone, Okayama pref. is the maximum, $10 \mathrm{mg} / \mathrm{l}$ obtained from the pond group in Takamatsu, Kagawa pref. being followed. In the rest of the pond groups, around $5 \mathrm{mg} / l$ is the measured value in most cases. In this regard, there is no general tendency worthy of particular mention nor is there any special regional feature.

Fe-ion : Fe-ion, like other ions, is shown by its average value, which, however, seldom can characterize the regional group of ponds, because some of the ponds belonging to the same group are exceptionally richer in Fe-ion than in the others. Generally speaking, there are very few ponds in which more than $1 \mathrm{mg} / l$ of $\mathrm{Fe}-$ ion content is detectable. Therefore, it is because a pond or ponds with an abnormally high content of Fe-ion; some regional pond groups show higher mean value than in the others. For instance, the mean value of $4 \mathrm{mg} / l$ in the case of the pond group in Takamatsu, Kagawa pref. is resultant from the $18 \mathrm{mg} / \mathrm{l}$ content in pond No. 6 , and $6.0 \mathrm{mg} / l$ and $6.5 \mathrm{mg} / l$ in the pond No. 254 and pond No. 255 respectively boosts up the regional mean value of the Sennan area, Osaka pref. to $2.2 \mathrm{mg} / \mathrm{l}$. Accordingly, the mean value of $\mathrm{Fe}$-ion content in each regional pond group is of little signifiicance, unless each pond is examined in regard to its $\mathrm{Fe}$-ion content and the effect thereof.

$\mathbf{P O}_{4} \equiv, \mathbf{N H}_{4}{ }^{+}$and $\mathbf{N O}_{3}{ }^{-}$: These ions are of primary importance as nutritive salts for the organisms in ponds. They generally increase, as trophication progress, but in this regard, there are not only drastic seasonal fluctuations but also amazing differences between one pond and another. The mean value of more than $1 \mathrm{mg} / l$ of $\mathrm{PO}_{4} \equiv$ is shown only by the pond group in the alluvial lowlying land of the Sennan area, Osaka pref., and in the pond groups of the other regions, less than $0.1 \mathrm{mg} / l$ is its mean value. More than $1 \mathrm{mg} / l$ of $\mathrm{NH}_{4}{ }^{+}$is detectable in the pond groups of the Sennan area, Osaka pref., the Matsuyama area, Ehime pref. and the Takamatsu and the Marugame areas, Kagawa pref., respectively, and more than $1 \mathrm{mg} / l$ of $\mathrm{NO}_{3}{ }^{-}$only in the pond group of the Kamo- 
gata area, Okayama pref. As for the pond groups in the other regions, these ions are slightly present or utterly absent.

b) Frequency of the Occurrence of Plankton in Each Pond Group

As described above, the pond groups on the alluvium are to be more eutrophic than those on the diluvium. The writer previously published reports (1952

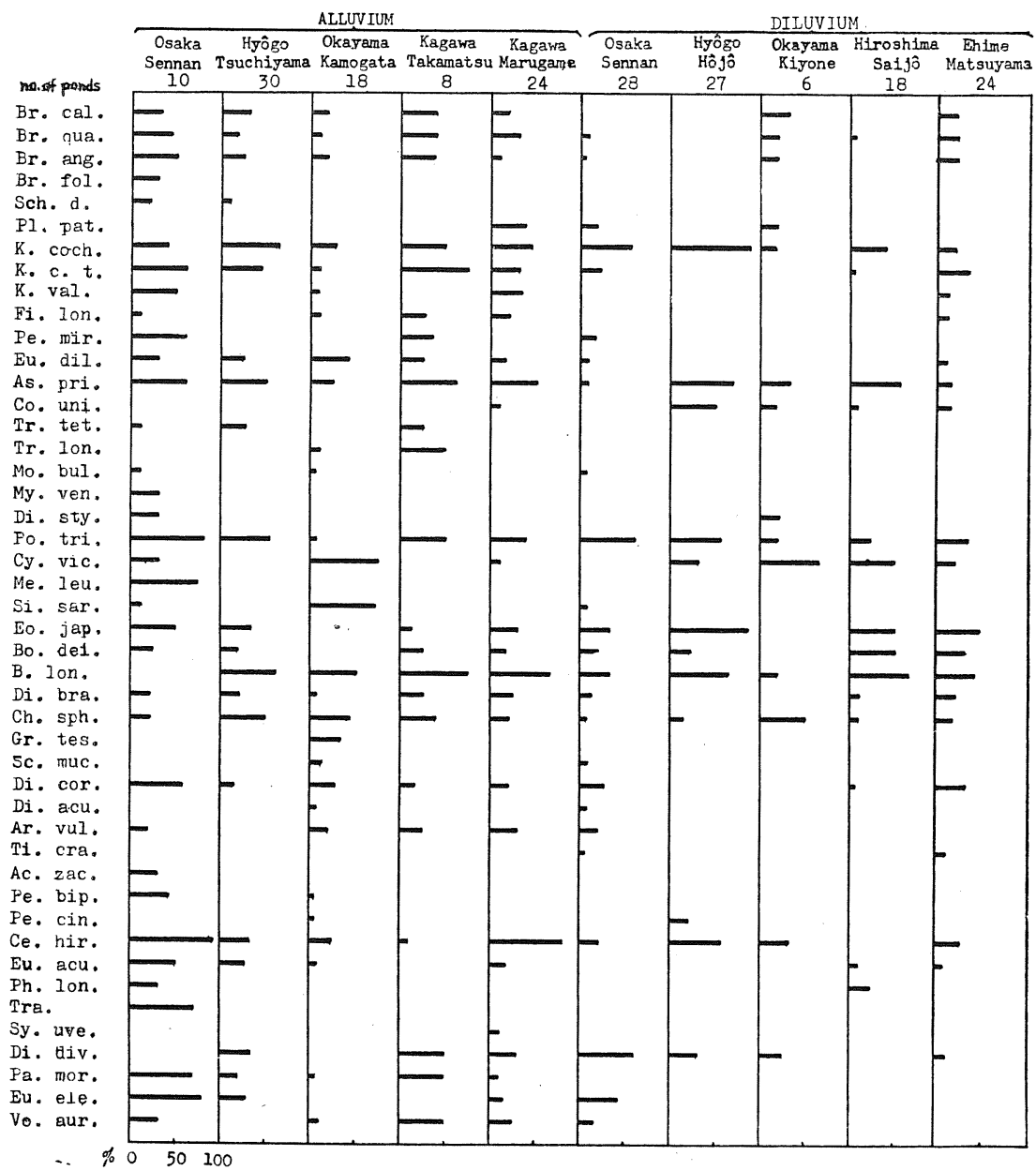

Fig. 6. The frequency of occurrence $(\%)$ of the zooplankton in the pond groups on the coast of the Inland Sea. 
1957) on the planktonic species and their occurrence in each pond, on the basis of which is shown here in Figs. 5 and 6 the percentage of the frequency of occurrence of each species. An attempt is often made to clarify the planktonic species and the volume of plankton in a particular pond group or to discuss the chemical conditions of it, but actually this is very impracticable, for even in two

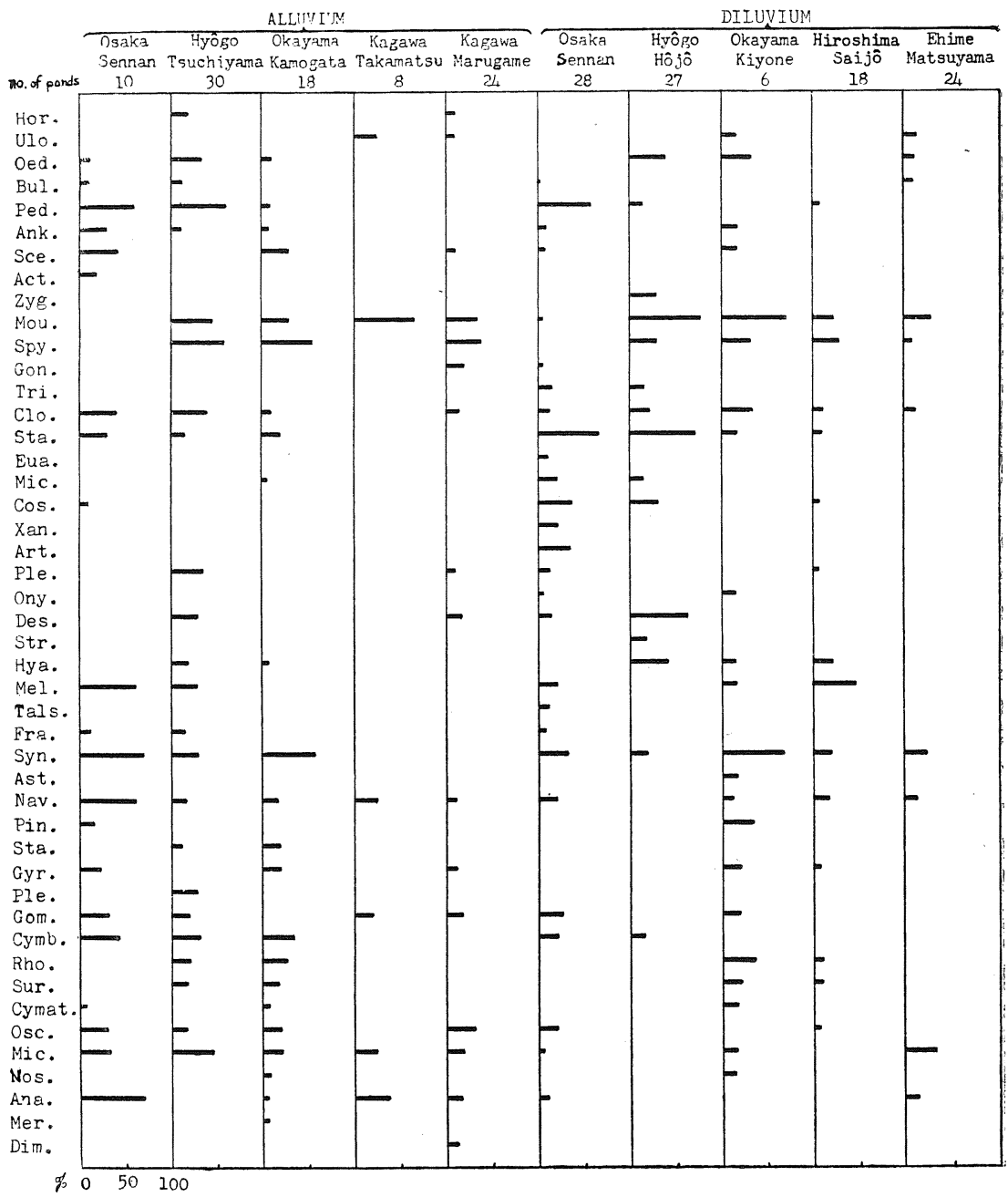

Fig. 7. The frequency of occurrence $(\%)$ of the phytoplankton in the pond groups on the coast of the Inalnd Sea. 
ponds, homogenous in their characters and even situated side by side, it does not seldom occur that certain species are found in common, or found in one pond alone or not found at all in either of the two. Furthermore, the occurring species vary sometimes season by season, and those which occur in one year do not always occur in the following year. Such time-lag is often seen in the occurrence of the same species, too. Failure to discover a certain species in the water sample obtained, therefore, does not necessarily endorse the nonexistence of it in the pond concerned. Conversely, the existence of a certain species makes it safe in no way to infer the chemical conditions and environmental factors of the pond investigated. This is because organisms have not only quite a large optimum range but a considerable degree of adaptability for their environments.

Accordingly, the most appropriate method of investigation is to take up approximately the same type of ponds in the same area at approximately the same period and to find out the general tendency of planktonic occurrence in the ponds. Considered thus, the frequency of planktonic occurrence in each case is shown here by the value obtained from a formula of

$$
\frac{\text { Nos. of ponds where planktonic species occurred }}{\text { Nos. of ponds investigated }} \times 100 \text {, }
$$

and the character of different species or genus is dealt with.

Rotifera : It is generally known that rotifers belong to the group of estival species and that it prefers eutrophic waters. Among the common species, such as Keratello cochlearis, K. cochlearis var. tecta, Polyarthra trigla, Asplanchna priodonta and others show a large optimum range respectively. But the genera of Brachionus, Filinia, Trichocerca and others seem to be more restricted to their existence range than the afore-stated species, when viewed from the fact that they seldom occur in the oligotrophic waters in such places as Hôjô, Hyôgo pref., the tableland in the southern part of Osaka, and Saijô, Hiroshima pref. The occurrences of Brachionus and Filinia in the ponds at Kiyone, Okayama pref. and on the tableland of Matsuyama, Ehime pref., suggest the advanced eutrophication of these ponds, with which, as a matter of fact, the analytical results of the water samples are in perfect agreement.

Copepoda: To this order belongs various species all of which have a very wide optimum range. Above all, Cyclops vicinus and Eodiaptomus japonicus are found both in the oligotrophic and in the eutrophic waters. The species such as Thermocyclops taihokuensis, Mesocyclops leuckarti, Eucyclops serrulatus, Eodiaptomus formosus and others cannot be found in every pond, but there is a tendency that they occur very abundantly in certain ponds.

Cladocera : Half the species collected are of cosmopolitan distribution and the frequency of their occurrence is very high. Among these can be counted such as Bosmina longirostris, Bosminopsis deitersi, Diaphanosoma brachyurum, Alona guttcta, Chydorus sphaericus and others. Moina macrocpa appears in summer and Daphnia pulex in winter, but there is a tendency that they occur in certain 
ponds only. The other species are so sporadic in their occurrence that no regional feature is detectable.

Protozoa : Diffugia corona and Ceratium hirundinella have the widest distribution. It seems that Dinobryon divergens has a preference for oligotrophic ponds and Arcellc, Euglena, Phacus, Trachelomoncs, Eudorina, Volvox and others for ponds of an eutrophic type in the low-lying lands.

Chlorophyta: Among the phytoplankton, Chlorophyta has a large number of species. In Fig. 6, only the generic names are given. Desmids such as Triplocercs, Stcurcstrum, Eucstrum, Micrcsterics, Cosmarium, Xonthidium, Arthrodesmus, Pleurotcenium, Spondilosium, Desmidium, Gymnozygon, Hyolotheca and others occur in the ponds on the tableland centering around the southern part of Osaka pref. and the Hôjồ area of Hyôgo pref. In those districts there are discovered those species which are found in the mountain lakes and swamps on the uplands as well as those found only in the tropical and subtropical areas. Many of them have a preference for the acid and oligotrophic waters. They may be called a group of highly characteristic planktonic species. It seems that some species belonging to the genera of Oedogonium, Pediastrum, Mougeotia, Spirogyra, Closterium and Stcurcstrum have a wide range of distribution both in the oligotrophic ponds on the diluvial tablelands and in the eutrophic ponds on the alluvium.

Bacillariophyta : Of diatoms the most common species belong to Synedra, Melosira, Ncvicula and next to them come Gyrosigma, Gomphonema, Cymbella, Rhopalodic, Surirella, Pinnulcric and others. Apart from Frustulia rhomboides, which has a preference for the waters in the mountainous area and Nitzschia scalcris and Pleurosigma dilicatulum, whose liking is for the waters near the seashore, diatoms generally have a rather wide optimum range.

Myxophyta : Oscillatoric, Microcystis, Nostoc, Anabaenc and Lyngbya are sometimes found scantily in dammed-up ponds in the eroded valleys of mountains, but their chief habitats are the contaminated and eutrophic ponds, where there occur often a severe 'water-bloom'. Most of the water-bloom are composed of Microcystis, but pond No. 8 in the northern part of Osaka is covered with a scum composed of Oscillctoria kawamurce, with the water-surface coloured either green or reddish-brown.

With regard to the principal species of plankton found in these ponds, the present writer $(1957,1958)$ investigated the existence range of each different species for $\mathrm{pH}, \mathrm{Cl}^{-}, \mathrm{SO}_{4}=, \mathrm{KMnO}_{4}$ cons., $\mathrm{Ca}^{++}, \mathrm{Fe}^{++}$and $\mathrm{SiO}_{2}$ respectively. The findings prove consistent with the results obtained more recently by the writer in connection with the frequency of occurrence of the same species. If some plankton indicators are to be selected from the planktonic species in discussing the relation between the chemical conditions and planktonic organisms, they must be those species whose ranges of optimum living conditions are narrow, but which never fail to occur within such limited range. This problem will be taken up and discussed later again. 


\section{c) Relations between Eutrophication of Pond-waters and Plankton}

The relations between eutrophication of pond waters and plankton were touched upon in the preceding section, but it was in connection with different species or genera. In Europe and America, attempts have been made at classification of lakes by employing the ratio of the numbers or volumes of certain particular phytoplanktonic species. For instance, Thunmark (1945) made use of his ChlorococcalesDesmidiaceae System, that is, the formula of $\frac{\text { Chlorococcalenartenzahl }}{\text { Desmidieenartenzahl }}=\frac{C_{A}}{D_{A}}$, and if this ratio was found to be $>1$, the lake in question was referred to the eutrophic type, and if $<1$, to the oligotrophic type. NygaARD (1949) tried to classify lakes by employing the Chlorophyceen-Quotient, that is,

$\frac{\text { Myxophyceen }+ \text { Euglenineen }+ \text { Zentrische Diatomeen }+ \text { Chlorococcalen }}{\text { Desmidieen }}=\frac{\Sigma \mathrm{MEZC}_{\mathrm{A}}}{\mathrm{D}_{\mathrm{A}}}$,

Litтieroth (1950) applied this formula to his studies of Lake Asljungaajön and Västa Sorrödssion. If $\frac{\Sigma \mathrm{MEZC}_{A}}{\mathrm{D}_{\mathrm{A}}}$ was $>1$, it was considered to suggest an eutrophic lake and if $<1$, an oligotrophic lake. Its quotient ranging from 1 to 3 was considered to denote weak eutrophy and its quotient of $>3$ strong eutrophy.

In our country, no attempt seems to have hitherto been made at classification of ponds by applying such methods. Using many data obtained from the investigation of the pond groups on the coasts of the Inland Sea, the writer applied NygaARD's method. The results are as follows :

Area Guotient

Southern part of Osaka pref. $\frac{7}{69}=0.1$

Hôjô area, Hyôgo pref. $\frac{12}{48}=0.25$

Tsuchiyama area, Hyôgo pref. $\frac{7}{9}=0.77$

Group B ponds in the northern part of Osaka pref. $\cdots \cdots \cdots \cdots \frac{7}{8}=0.87$

Saijô area, Hiroshima pref. $\frac{6}{6}=1.0$

Takamatsu area, Kagawa pref. $\frac{9}{7}=1.3$

Marugame area, Kagawa pref. $\frac{6}{4}=1.5$

Kamogata area, Okayama pref. $\frac{13}{8}=1.6$

Kiyone area, Okayama pref. $\frac{7}{4}=1.7$

Matsuyama area, Ehime pref. $\frac{4}{1}=4.0$

Group $\mathrm{C}$ ponds in the northern part of Osaka pref. $\cdots \cdots \cdots \cdots \cdot \frac{14}{3}=4.6$ 
The results given above show that the ponds in the southern part of Osaka pref. and in the Hôjô area, Hyôgo pref. are oligotrophic ; Group B ponds in the northern part of Osaka pref., those in the Saijô area, Hiroshima pref. and the Tsuchiyama area, Hyôgo pref. mesotrophic; the pond groups in both areas of Takamatsu and Marugame, Kagawa pref. and both the Kiyone and the Kamagata area, Okayama pref. slightly eutrophic ; and Group C ponds in the northern part of Osaka pref. and those in the Matsuyama area, Ehime pref. strongly eutrophic. These results are in complete agreement with the analytical results of the water samples collected, confirming still further the greater tendency for eutrophication pointed out by the writer in regard to the ponds in the Kiyone area, Okayama pref. and the Matsuyama area, Ehime pref. as compared with the other pond groups lying on the same diluvial tablelands.

\section{POND GROUPS ON THE COASTS OF ISLANDS}

As compared with the ponds on the diluvium, those on the alluvium were found to be more eutrophic. In many of these ponds on the alluvium, however, the $\mathrm{Cl}^{-}$ content is considerably higher, even when they are embanked on all sides and have no catchment areas. Therefore, if it is supposed that there is no water-source to depend upon except rainfall, the effect of the sea-breeze must naturally be taken into consideration.

In this connection, Kurashige (1933) drew attention to the larger $\mathrm{Cl}^{-}$content in the coastal ponds lying in the Kubiki plain of Nigata than in the inland waters. Following upon his heels, Yoshimura (1933a, 1936a) discovered the existence of inverse proportion between the content of $\mathrm{Cl}^{-}$and the distance from the seashore based on his investigations of the three maar-lakes in the Oga Peninsula and the Kurashige's data. Approximately the same remarks were made in this regard by Mori (1934) and S. YaMAMoto (1941).

In the field of descriptive geography, IzU (1913) and IWASAKI (1934) investigated the damage done to the agricultural products by $\mathrm{Cl}^{-}$. From the meteorological and microchemical viewpoints, too, relevant researches were made by Matsudaira (1937, 1937a), Takayanagi (1941), Sugawara (1948) and Gorham (1957). There is also a report on this matter published by the Inquiry Committee on the Economic Affairs of the Snowy Agriculatural Districts.

Consequently, it is quite evident that the effect of the sea reaches pretty far inland through such media as atmosphere, rain and snow. This chapter, therefore, is intended for the clarification of (1) the effect of the sea on freshwater ponds, (2) the range of freshwater ponds as such, and (3) the character of plankton in this kind of ponds.

\section{A. Physical and Chemical Conditions of the Ponds on Each Island \\ a) Sadoga-shima Island}

This is the largest of all the islands off the coast of the Japan Sea, and in its 
central fault trough there are many artificial ponds arranged from west to east. The island, therefore, is a particularly appropriate place for the study of the effect of the continental monsoon on the pond waters. These ponds were divided into four groups as follows:

1st Group. Pond group on the coastal terrace $5 \sim 10 \mathrm{~m}$ above sea level and within $500 \mathrm{~m}$ of the coastline.

2nd Group. Pond group within $1 \sim 2 \mathrm{~km}$ of the western coastline.

3rd Group. Pond group in the central part of the island and within $5 \sim 7 \mathrm{~km}$ of the western coastline.

4th Group. Pond group within $1 \sim 2.5 \mathrm{~km}$ of the eastern coastline.

Most of these ponds are dammed-up ones, with no dwelling houses in their neighbourhood. In each of them, therefore, contamination due to domestic drainage is unlikely. Neither is there any underground infiltration of sea water into it, since they are situated on the coastal high terraces. Table 5 shows the mean values of the analytical results of the pond water samples.

Table 5. The mean value of chemical analyses of the water of the ponds on the Sadoga-shima Island, (1954).

(A. T. and W. T.: ${ }^{\circ} \mathrm{C}$; dissolved substances : $\mathrm{mg} / l$ )

\begin{tabular}{c|c|ccccccccccc}
\hline \hline Dist. & Date & A.T. & W. T. & $\mathrm{pH}$ & $\mathrm{Cl}$ & $\mathrm{SO}_{4}$ & $\begin{array}{c}\mathrm{KMnO}_{4} \\
\text { cons. }\end{array}$ & $\mathrm{Ca}$ & $\mathrm{SiO}_{2}$ & $\mathrm{Fe}$ & $\mathrm{PO}_{4}-\mathrm{P}$ & $\mathrm{NH}_{4}-\mathrm{N}$ \\
\hline $\mathrm{I}$ & $\mathrm{X} .5$ & 22.9 & 19.5 & 6.5 & 97.8 & 10.96 & 14.19 & 31.2 & 7.41 & 2.81 & 0.01 & 1.54 \\
$\mathrm{II}$ & $\mathrm{X} .5$ & 23.3 & 21.6 & 6.92 & 34.9 & 9.48 & 13.35 & 15.2 & 5.60 & 0.15 & 0.04 & 0.156 \\
$\mathrm{III}$ & $\mathrm{X} .6$ & 21.7 & 20.3 & 6.2 & 14.9 & 1.68 & 14.70 & 29.65 & 4.35 & 0.21 & 0.57 & 0.35 \\
$\mathrm{IV}$ & X. 6 & 16.3 & 20.3 & 6.7 & 13.6 & 1.96 & 15.80 & 20.7 & 6.75 & 0.053 & 0.19 & 1.02 \\
\hline
\end{tabular}

I : Pond group within $500 \mathrm{~m}$ distant from the western coastline.

II : Pond group within $1 \sim 2 \mathrm{~km}$ the western coastline.

III : Pond group in the central part of Sadoga-sima Island.

IV : Pond group within $1 \sim 2.5 \mathrm{~km}$ the eastern coastline.

Both $\mathrm{Cl}^{-}$and $\mathrm{SO}_{4}=$ showed the most remarkable differences in all these pond groups, though a few other ions also characterized each pond group. Fig. 8 shows the distribution of ponds newly arranged on the basis of the relationship between the content of $\mathrm{Cl}^{-}$and the distance from the seashore.

The above-figure will show at a glance that, so far as the ponds of the 1st Group are concerned, the greater the distance from the coastline is, the more drastically the $\mathrm{Cl}^{-}$content is found to decrease, and that this decrease becomes less marked in the ponds lying more than $1 \mathrm{~km}$ away from the coastline. What attracts notice next is that when comparison is made between the 2nd Group and the $4 \mathrm{th}$, both of which are situated within $2 \mathrm{~km}$ of the coastline in the east and west of the island respectively, there are considerable differences in $\mathrm{Cl}^{-}$content. From the finding mentioned first, the theory proposed by Yoshimora and Yamamomo 


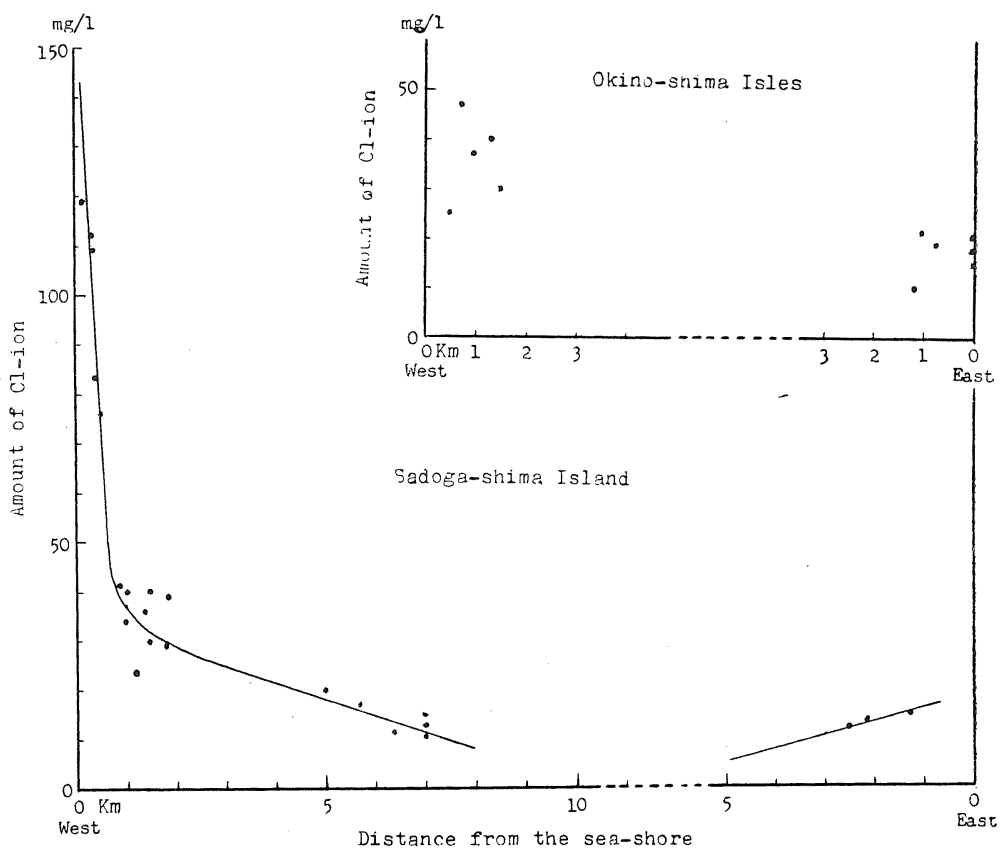

Fig. 8. The relationship between the $\mathrm{Cl}$-ion content and the distance from the seashore, shown by the ponds on the Sadoga-shima Island and the Okino-shima Islands.

seems to become to some doubt. It may be that their theory is valid only when the number of ponds is limited and these ponds were investigated one by one, starting with the one lying more than $500 \mathrm{~m}$ away from the coastline. If, therefore, these coastal islands are rearranged in their investigation according to the distance: from the coastline in respective case, it seems more natural to show in a hyperbola or two different straight lines in this connection. From the finding mentioned next and also from the change in the $\mathrm{Cl}^{-}$content according to the distance of each pond from the coastline, both the direction and velocity of the wind will be considered to have much to do with them. The writer, therefore, made use of the data compiled by the Aikawa Meteorological Station concerning the monthly directions and velocities of winds during the year 1958. The results obtained are as follows.

From December till March the winds blow there chiefly from the direction of WS or WNW with the maximum frequency and its mean velocity is the greatest in these four months of the year, while, the winds that blow from April till November come chiefly from ES, with their mean velocity remarkably reduced. 

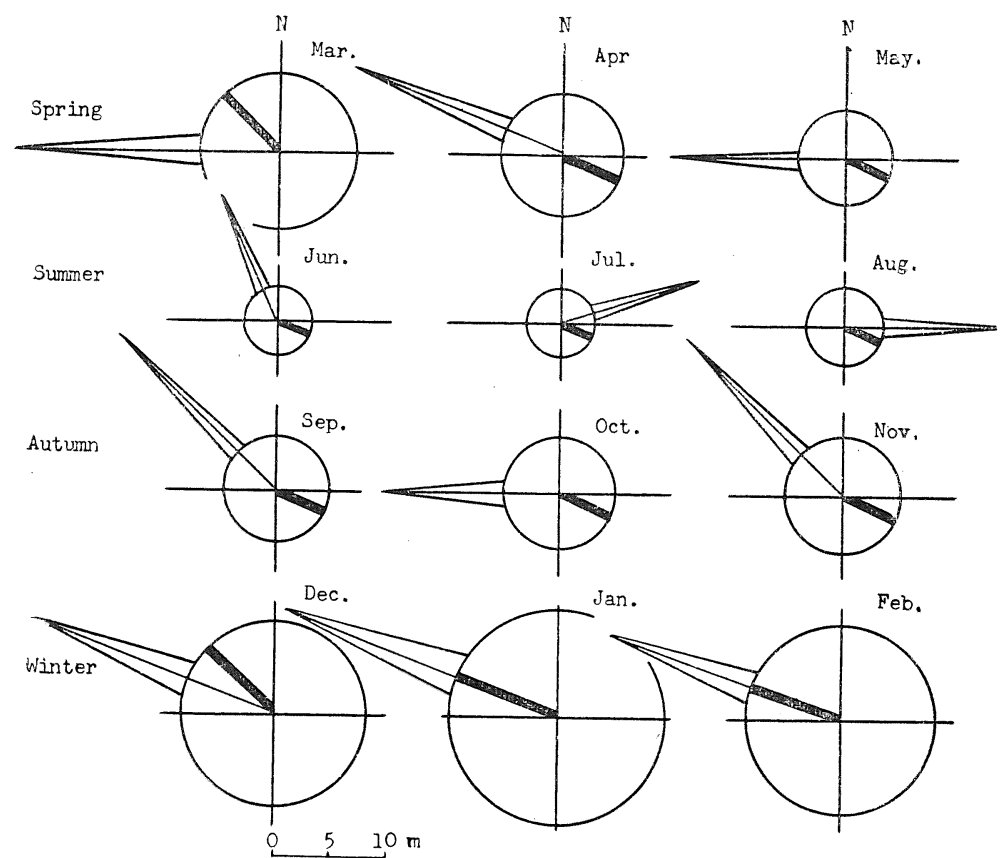

Fig. 9. The mean directions and velocities of winds during the year 1958 at Aikawa on the Sadoga-shima Island.

Radius : Means of wind velocity $(\mathrm{m} / \mathrm{sec}$.) in each month. Thick line: Wind direction with the maximum frequency in each month.

Projecting part: Maximum of wind velocity and its direction (10 min.)

Thus, it is pretty understandable why the $\mathrm{Cl}^{-}$content is large in the 1 st and 2nd Pond Groups on the western coast and why there are remarkable difference between the 2nd Pond Group and the 4th one in the east and west of the island respectively.

\section{b) Okino-shima Islands}

Okino-shima is composed of several islands, each centre of which is occupied by mountains, and ponds lie scattered in the coastal valleys. Researches were made by selecting several ponds lying on the eastern and western coasts. Hardly any contamination due to domestic drainage was observable in each of them. Oike and Me-ike on the eastern coast of Dôgo Island are situated in a steeply-sloping valley and although only $20 \sim 30 \mathrm{~m}$ away from the seashore, they are $1 \sim 2 \mathrm{~m}$ above 
Table 6. The mean value of chemical analyses of the water of the ponds on the Okino-shima Islands, (1959).

(A. T. and W. T. : ${ }^{\circ} \mathrm{C}$; dissolved substaces : $\mathrm{mg} / l$ )

\begin{tabular}{c|c|c|c|c|c|c|c|c|c|c|c|c}
\hline \hline Dist. & Date & A.T. & W.T. & $\mathrm{pH}$ & $\mathrm{Cl}$ & $\mathrm{SO}_{4}$ & $\begin{array}{c}\mathrm{KMnO}_{4} \\
\text { cons. }\end{array}$ & $\mathrm{Ca}$ & $\mathrm{SiO}_{2}$ & $\mathrm{Fe}$ & $\mathrm{PO}_{4}-\mathrm{P}$ & $\mathrm{NH}_{4}-\mathrm{N}$ \\
\hline $\begin{array}{c}\text { Eastern } \\
\text { coast }\end{array}$ & VI $27-28$ & 26.3 & 26.6 & 7.1 & 27.4 & 14.4 & 10.9 & 21.8 & 17.6 & 2.6 & - & 0.87 \\
$\begin{array}{c}\text { Western } \\
\text { coast }\end{array}$ & VI 29-30 & 26.2 & 27.1 & 6.8 & 52.0 & 15.7 & 15.7 & 26.3 & 11.0 & 3.3 & - & 0.12 \\
\hline
\end{tabular}

sea level. The $\mathrm{Cl}^{-}$content in these two ponds was unexpectedly small, being $29.8 \mathrm{mg} / l$ and $24.8 \mathrm{mg} / l$ respectively. A few ponds on the slope of lino-yama is about $1 \mathrm{~km}$ away from the seashore. They showed the $\mathrm{Cl}^{-}$content of $20 \sim 30$ $\mathrm{mg} / l$. The pond on the hill on Dôzen Island is only about $50 \mathrm{~m}$ away from the

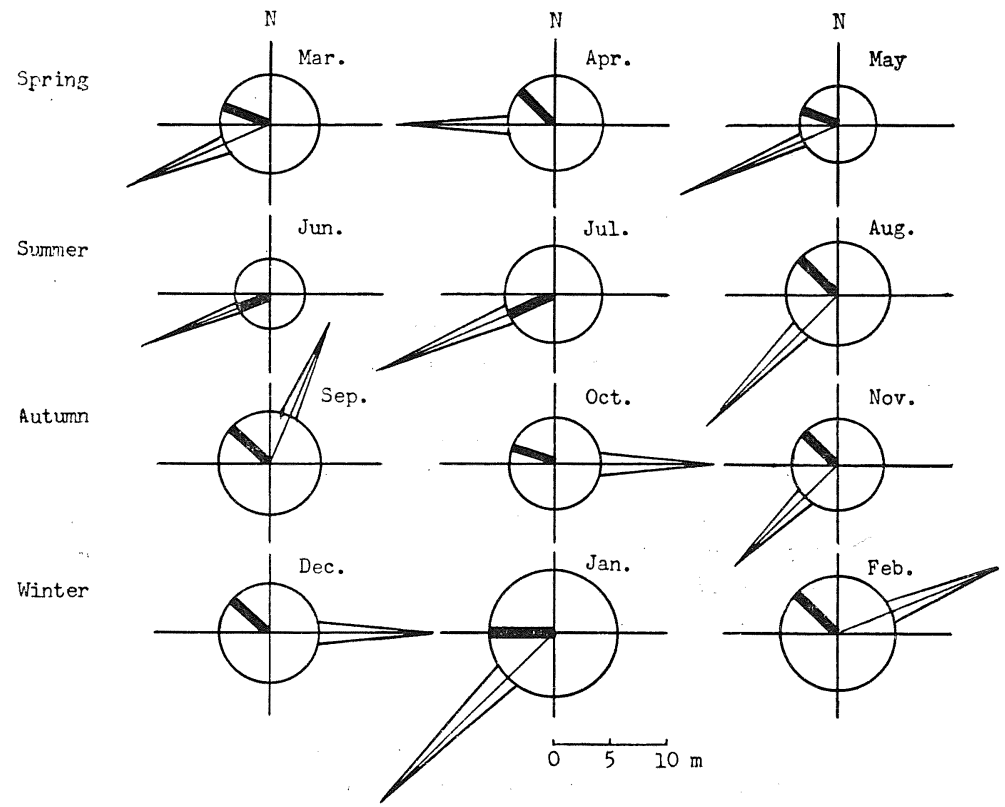

Fig. 10. The Mean directions and velocities of winds during the year 1958 at Saig $\hat{\jmath}$ on the Okino-shima Island.

Radius: Means of wind velocity ( $\mathrm{m} / \mathrm{sec}$.) in each month.

Thick line: Wind direction with the maximum frequency in each month.

Projecting part: Maximum of wind velocity and its direction (10 min.) 
Table 7. The chemical analyses of the water of the ponds on the Rishiri-tô

\begin{tabular}{c|c|ccccc}
\hline \hline Ponds & Date & A. T. & W. T. & pH & $\mathrm{O}_{2}$ & $\mathrm{Cl}$ \\
\hline Menuushoro-numa & VIII 19 & 22.5 & 21.9 & 5.6 & 3.5 & 24.0 \\
Otadomari-numa & VIII 19 & 21.5 & 21.0 & 4.7 & 6.0 & 17.0 \\
\hline Mean & & 22.0 & 21.5 & 4.8 & 4.75 & 20.5 \\
\hline
\end{tabular}

seashore. It showed the $\mathrm{Cl}^{-}$content of $29.7 \mathrm{mg} / l$. In spite of their proximities to the seashore, these artificial ponds unmistakably have an unexrectedly small $\mathrm{Cl}^{-}$content.

The ponds, situated $0.7 \sim 1.5 \mathrm{~km}$ away from the western coastline, indicate the $\mathrm{Cl}^{-}$content of $30 \sim 47 \mathrm{mg} / \mathrm{l}$, which is larger than that in those on the eastern coast (See Table 6). Katsuta-ike on Dôzen Is. had the maximum C1- content of 130 $\mathrm{mg} / l$, while Yuino-ike on Dôgo Is. had a lesser $\mathrm{Cl}^{-}$content of only $25 \mathrm{mg} / \mathrm{l}$, notwithstanding its distance from the coastline. Judging from the geomorphological viewpoint, this pond seems to be a natural pond left at the bottom of a large lake as a result of gradually lowered water level. Although surrounded by paddy-fields, the adjoinning space of ground is so deeply muddy that it is difficult to access; it seemed to be once the lake bottom. Around the pond the emergent vegetation is found growing densely and the water colour is dark brownish. Having been indicated by the $\mathrm{KMnO}_{4}$ consumption of $33 \mathrm{mg} / l$, the pond may belong to a dystophic type unlike the other ponds in this district. This pond, therefore, may be considered to represent a special type as an evolutional successor to the lake that existed formerly.

According to the data compiled by the Saigô Meteorological Station, the winter winds mostly blow from the direction of W-WN as on Sadoga-shima. This windy season lasts longer here than on Sadoga-shima, but the mean velocity throughout the year is considerably smaller. There is little doubt that the differences of $\mathrm{Cl}^{-}$ content between the eastern and western coasts are affected by the principal directions of the wind and its velocities.

\section{c) Rishiri-tô Island}

Rishiri-tô, off the northwestern part of Hokkaido, is a solitary and volcanic island. Because of its geological formation and unfavorable climatic conditions, most of the residents there are engaged not in farming but in fishing. Accordingly there is no artificially constructed pond. In an area near the southeastern coast of this island, however, there are a few natural marshes, -Menuushoro-numa, Otadomari-numa and others. Presenting a dark brownish colour, and being strongly acid, with the $\mathrm{pH}$ value of 4.3 or 5.6 and the $\mathrm{KMnO}_{4}$ consumption of $71.9 \mathrm{mg} / l$, they belong distinctly to the dystrophic type. The results of chemical analysis of the water are as follows. In spite of their proximity to the coastal 
Island, (1957). (A.T. and W. T. : ${ }^{\circ} \mathrm{C} ; \mathrm{O}_{2}: \mathrm{cc} / l$; dissolved substances : $\mathrm{mg} / l$ )

\begin{tabular}{rccrcccc}
\hline $\mathrm{SO}_{4}$ & $\begin{array}{c}\mathrm{KMnO} \\
\text { cons. }\end{array}$ & $\mathrm{Ca}$ & $\mathrm{SiO}_{2}$ & $\mathrm{Fe}$ & $\mathrm{PO}_{4}-\mathrm{P}$ & $\mathrm{NH}_{4}-\mathrm{N}$ & $\mathrm{NO}_{3}-\mathrm{N}$ \\
\hline 56.0 & 71.9 & 12.0 & 11.6 & 7.0 & 12.0 & 0.7 & 0.005 \\
35.0 & 28.3 & 18.0 & 5.0 & 1.0 & 14.0 & 0.3 & 0.007 \\
\hline 45.5 & 50.1 & 15.0 & 8.3 & 4.0 & 13.0 & 0.5 & 0.006 \\
\hline
\end{tabular}

cliff and their small area of water surface, the $\mathrm{Cl}^{-}$content is unexpectedly small, but the nutritive substances are comparatively rich.

\section{d) Tobi-shima Island}

This is a small island situated off the northwestern coast of Sakata City, Yamagata pref. It is very thinly populated and has very few fields under cultivation. Accordingly, it has no pond artificially constructed for irrigation, but there is a reservoir serving as simple water supply works (about 900 square meters and 5 6 meters in depth), a concrete reservoir $(10 \times 15 \times 3 \mathrm{~m})$ and another temporary pool of water ( $2 \mathrm{~m}$ in diameter and $0.3 \mathrm{~m}$ in depth) naturally formed in a claypit left in a pine-wood in the central part of the island. The results of chemical analysis of water are as follows (Table 8). Since the former two reservoirs are situated within $30 \sim 50 \mathrm{~m}$ from the seashore, the $\mathrm{Cl}^{-}$content is comparatively large.

Table 8. The chemical analyses of the water of the ponds on the Tobi-shima Island, (1957). (A.T. and W.T.: ${ }^{\circ} \mathrm{C} ; \mathrm{Cl}$ and $\mathrm{KMnO}_{4}$ consumption: $\mathrm{mg} / \mathrm{l}$ )

\begin{tabular}{|c|c|c|c|c|c|c|c|}
\hline Ponds or pool & Date & A. $T$. & W. T. & $\mathrm{pH}$ & $\mathrm{Cl}$ & $\begin{array}{l}\mathrm{KMnO}_{4} \\
\text { cons. }\end{array}$ & $\begin{array}{l}\text { Distance from } \\
\text { the seashore }\end{array}$ \\
\hline $\begin{array}{l}\text { Concrete reservior } \\
\text { at Katsuura }\end{array}$ & VII 30 & 27.5 & 25. 0 & 6.0 & 95.0 & 18. 33 & about $30 \mathrm{~m}$ \\
\hline $\begin{array}{l}\text { Simple water-supply } \\
\text { survice at Nakamura }\end{array}$ & $\prime \prime$ & 28.0 & 28. 0 & $>7.4$ & 76.0 & 32.02 & $50 \mathrm{~m}$ \\
\hline $\begin{array}{l}\text { Small pool in the } \\
\text { pine forest }\end{array}$ & $\prime \prime$ & 27.5 & 27.3 & 5.4 & 46. 0 & 56.88 & $" 500 \mathrm{~m}$ \\
\hline
\end{tabular}

\section{e) Miyake-jima Island}

This is a volcanic island situated about $150 \mathrm{~km}$ south of Tokyo City. In the eastern part of the island there are two ponds, Tairo-ike and Shinmyô-ike, both of which are said to have been craters and are filled with water now. Shitori-ike $A$ and B on the eastern coast of the island came into existence in 1940 when a volcanic eruption occurred there, the mouth of an inlet being closed up with cinder and lava. Except these natural ponds, no artificial pond is found there. Both Tairo-ike and Shinmyô-ike were investigated by Yoshimura and Miyadi (1936) and by Fukushima (1958). According to them, Shinmyô-ike pond seems 
Table 9. The chemical analyses of the water of the ponds on the Miyake-

\begin{tabular}{|c|c|c|c|c|c|}
\hline Ponds & Date & A. $T$. & W. T. & $\mathrm{pH}$ & $\mathrm{Cl}$ \\
\hline Tairo-ike & VIII 15 & 28.5 & 28.2 & 7.8 & 73. 0 \\
\hline Shinmyô-ike..... & $\prime \prime$ & 29.9 & 29.6 & 8.8 & 780.0 \\
\hline Shitori-ike A $\ldots \ldots \ldots \ldots \ldots \ldots \ldots \ldots$ & VIII 16 & 27.8 & 25.2 & 8.4 & 520.0 \\
\hline Shitori-ike $B \ldots \ldots \ldots \ldots \ldots \ldots \ldots \ldots$ & 11 & 28.2 & 25. 0 & 8.3 & 1900.0 \\
\hline
\end{tabular}

to be connected with the sea. The results of chemical analysis obtained by the writer showed that the $\mathrm{Cl}^{-}$content was $73 \mathrm{mg} / l$ in Tairo-ike pond, $780 \mathrm{mg} / l$ in Shinmyô-ike pond, $520 \mathrm{mg} / l$ in Shitori-ike pond A, and, and $1900 \mathrm{mg} / l$ in Shitoriike pond $\mathrm{B}$. The high $\mathrm{Cl}^{-}$content of Shitori-ike pond $\mathrm{B}$ is being reduced gradually but seasnails are still found living in it.

\section{f) Hachijô-jima Island}

This is a volcanic island $150 \mathrm{~km}$ farther south of the Miyake-jima Island. In the central low-lying land between the two volcanoes in the north and south there is a pond called Izumi-ike. Nakanogô village in the southwestern part of the island has also several ponds in its valleys. There are two moor pools on the top of Mt. Hachijô-fuji. Being a small island in the ocean, there is often visited by typhoon. Contrary to the writer's expectation that the ponds there might be affected greatly by such an environmental factor, the mean $\mathrm{Cl}^{-}$content in the ponds in the coastal low-lying area was only $26.3 \mathrm{mg} / l$. In the moor pools on the top of Hachijô-fuji, the $\mathrm{Cl}^{-}$content was very small. It was noticed that the amount of $\mathrm{Ca}^{++}$was particularly large. This may probably be attributable to

Table 10. The chemical analyses of the water of the ponds on the Hachijô-

\begin{tabular}{|c|c|c|c|c|c|}
\hline Ponds & Date & A. $T$. & W. T. & $\mathrm{pH}$ & $\mathrm{Cl}$ \\
\hline Izumi-ike $\quad \cdots \ldots \ldots \ldots \ldots \ldots \ldots \ldots \ldots \ldots \ldots \ldots \ldots$ & VIII 19 & 27.8 & 28.1 & 6.8 & 30.0 \\
\hline Nakanogô tame-ike A ......... & "I & 29.9 & 21.2 & 8. 6 & 25.0 \\
\hline Naknogaô tame-ike B ......... & $" 1$ & 29.4 & 24.2 & 8.2 & 25. 0 \\
\hline Nakanogô tame-ike $\mathrm{C}$.......... & $" 1$ & 29.0 & 26.6 & 7.8 & 25.0 \\
\hline Mean & & 29.0 & 25.0 & 7.85 & 26. 3 \\
\hline Mihara-gawa dam .......... & VIII 19 & 27.9 & 25.0 & 7.2 & 19.0 \\
\hline Hachijô-fuji pool A.............. & 1120 & 24.0 & 24.0 & 6.6 & 14.0 \\
\hline Hachijô-fuji pool B.................. & " 20 & 23.0 & 23.3 & 6.4 & 16. 0 \\
\hline Mean & & 25.0 & 24.0 & 6.73 & 16. 3 \\
\hline
\end{tabular}


jima, Island, (1959). (A. T. and W. T. : ${ }^{\circ} \mathrm{C}$; dissolved substances : mg/l)

\begin{tabular}{rcccccc}
\hline $\mathrm{SO}_{4}$ & $\begin{array}{c}\mathrm{KMnO}_{4} \\
\text { cons. }\end{array}$ & $\mathrm{Ca}$ & $\mathrm{SiO}_{2}$ & $\mathrm{Fe}$ & $\mathrm{PO}_{4}-\mathrm{P}$ & $\mathrm{NH}_{4}-\mathrm{N}$ \\
\hline 92.4 & 22.75 & 53.8 & 20.0 & 0.1 & 0.04 & 0.1 \\
210.0 & 51.10 & 74.8 & 33.0 & 0.2 & 0.04 & 1.5 \\
260.4 & 20.20 & 84.0 & 47.0 & 0.3 & 0.0 & 0.0 \\
260.4 & 23.70 & 161.3 & 25.0 & 0.1 & 0.0 & 1.1 \\
\hline
\end{tabular}

the geology of the island which came into existance as a result of volcanic eruption. Both the Miharagawa Dam and the moor pool on the top of Mt. Hachijô-fuji were found to have a small $\mathrm{Cl}^{-}$content. The latter indicated the characters of dystrophic nature with the mean value $72 \sim 73 \mathrm{mg} / l$ of $\mathrm{KMnO}_{4}$ consumption and a brownish colour of water.

\section{g) Amami-ôshima Island}

This is the largest island in the island group south of Kyûshû. Though there are brackish water pools, there are no artificially constructed ponds, with the exceptions of Shirigamata-ike pond in Akagina village and a small pond in the ground of the Ôshima Senior High School in Naze City. Two more bodies of water are added, the one the electricity generating dam in the upper reaches of the Sumiyô-gawa River, and the other the Gusuku-gawa reservoir near the eastern coast in the middle part of the island. The mean water temperature of the former two ponds is $33.5^{\circ} \mathrm{C}$ and the mean $\mathrm{pH}$ value 8.85. In the Gusuku-gawa reservoir, the water temperature is $26.0^{\circ} \mathrm{C}$ and the $\mathrm{pH}$ value 7.2 , because the water there is running. The $\mathrm{Cl}^{-}$content is not very large, though the island is often hit by

jima Island, (1959). (A. T. and W. T.: ${ }^{\circ} \mathrm{C}$; dissolved substances : $\mathrm{mg} / \mathrm{l}$ )

\begin{tabular}{rcccccc}
\hline \hline $\mathrm{SO}_{t}$ & $\begin{array}{c}\mathrm{KMnO}_{4} \\
\text { cons. }\end{array}$ & $\mathrm{Ca}$ & $\mathrm{SiO}_{2}$ & $\mathrm{Fe}$ & $\mathrm{PO}_{-}-\mathrm{P}$ & $\mathrm{NH}_{4}-\mathrm{N}$ \\
\hline 16.8 & 19.0 & 55.3 & 11.0 & 0.6 & + & 0.0 \\
15.9 & 10.5 & 41.1 & 32.0 & 0.6 & 0.0 & 0.0 \\
14.6 & 9.6 & 52.0 & 30.0 & 0.8 & 0.0 & 0.0 \\
8.4 & 11.4 & 39.0 & 27.0 & 0.1 & + & 0.0 \\
\hline 13.9 & 12.6 & 45.95 & 25.0 & 0.52 & + & 0.0 \\
\hline 14.6 & 11.4 & 51.2 & 24.0 & 0.6 & 0.03 & 0.0 \\
16.8 & 73.2 & 47.8 & 6.0 & 0.3 & 0.10 & 4.0 \\
14.7 & 72.1 & 63.9 & 2.5 & 0.3 & 0.2 & 3.0 \\
\hline 15.3 & 52.25 & 54.3 & 10.8 & 0.4 & 0.11 & 2.33
\end{tabular}


Table 11. The chemical analyses of the water of the ponds on the Amami-

\begin{tabular}{c|c|cccc}
\hline Ponds & Date & A. T. & W. T. & pH & Cl \\
\hline \begin{tabular}{c|c|c} 
Pond in Ôshima High School... \\
Shirigamata-ike....................
\end{tabular} & VIII 3 & 28.5 & 31.0 & 8.4 & 24.0 \\
\hline VIII 4 & 31.0 & 36.0 & 9.3 & 47.0 \\
\hline Mean & & 29.95 & 33.5 & 8.85 & 35.5 \\
\hline Sumuku-reservior ................ & VIII 7 & 32.0 & 27.0 & 7.2 & 33.0 \\
\hline Mean & VIII 8 & 33.0 & 25.0 & 7.2 & 17.0 \\
\hline
\end{tabular}

typhoons every year. The results of chemical analysis obtained are as above.

\section{h) Okinoerabu-jima Island}

This is a triangular island lying farther south of Amami-ôshima and is made up of elevated coral reefs. The eastern half of the island is a flat tableland that has many artiflcial ponds lying scattered. The soil is redish brown due to the weathering of the coral reef. The water colour of most of them is muddy brownish. Many ponds in this area is easy to come under the influence of the ocean because of the proximity of the area to the sea coasts on both sides and the frequent typhonic onslaught. This island is said to be once subsided below sea level in the geological time. For all these reasons, the $\mathrm{Cl}^{-}$content is generally

Table 12. The chemical analyses of the water of the ponds on the

\begin{tabular}{|c|c|c|c|c|c|}
\hline Ponds and caves & Date & A. $\mathrm{T}$. & W. T. & $\mathrm{pH}$ & $\mathrm{Cl}$ \\
\hline Mimitsuke-ike..... & VIII 12 & 36.0 & 36.0 & 8.4 & 56. 0 \\
\hline Kunigami-ike $\cdots$ & "l & 37.5 & 28.0 & 9.4 & 32.0 \\
\hline Debana-ike......... & $\prime \prime$ & 32.0 & 37.0 & 9.4 & 34.0 \\
\hline Paradais-ike .......... & $\prime \prime$ & 32.0 & 35.0 & 9.3 & 41.0 \\
\hline Mizukumi-ike $. . \ldots .$. & $\prime \prime$ & 31.0 & 34.0 & 9.4 & 29.0 \\
\hline Mean & & 33.7 & 34.0 & 9.2 & 38.4 \\
\hline Kimiru-kuragô....... & VIII 12 & 28.3 & 23.0 & 6.9 & 92.0 \\
\hline Kunigami-kuragô & " & 29.0 & 22.5 & 7.3 & 83.0 \\
\hline Oyama-kuragô........ & VIII 13 & - & 27.0 & 7.4 & 49. 0 \\
\hline Sumiy oshi-kuragô . & " 13 & - & - & - & 39. 0 \\
\hline Wa-kuragô $\quad . . . . . . . .$. & " 14 & 29.0 & 26.0 & 7.2 & 67.0 \\
\hline Mean & & 28.8 & 24.6 & 7. 2 & 66. 0 \\
\hline
\end{tabular}


ôshima Island (1958). (A. T. and W. T.: ${ }^{\circ} \mathrm{C}$; dissolved substances : $\mathrm{mg} / \mathrm{l}$ )

\begin{tabular}{rrrrlllll}
\hline $\mathrm{SO}_{4}$ & $\begin{array}{c}\mathrm{KMnO}_{4} \\
\text { cons. }\end{array}$ & $\mathrm{Ca}$ & $\mathrm{SiO}_{2}$ & $\mathrm{Fe}$ & $\mathrm{PO}_{4}-\mathrm{P}$ & $\mathrm{NH}_{4}-\mathrm{N}$ & $\mathrm{NO}_{0}-\mathrm{N}$ \\
\hline 14.3 & 2.53 & 18.0 & 6.2 & 0.01 & 0.0 & 0.01 & 0.005 \\
15.9 & 12.62 & 28.0 & 12.5 & 0.0 & 0.0 & 0.04 & 0.005 \\
\hline 15.1 & 7.57 & 23.0 & 9.35 & 0.005 & 0.0 & 0.025 & 0.005 \\
\hline 13.4 & 5.57 & 37.4 & 15.0 & 0.0 & 0.0 & 0.0 & 0.003 \\
8.4 & 3.55 & 16.0 & 10.2 & 0.1 & 0.0 & 0.03 & + \\
\hline 10.9 & 4.56 & 26.7 & 12.6 & 0.05 & 0.0 & 0.015 & 0.0015 \\
\hline
\end{tabular}

large. Owing to the greater rate of metabolism in the ponds with a high water temperature, the amount of dissolved organic substance is abundant, having a large amount of $\mathrm{KMnO}_{4}$ consumption. The high $\mathrm{Ca}^{++}$content may probably be due to the coral reefs. Table 12 shows the results of chermical analysis obtained. This island has also many limestone caves called 'Kuragô', in which the underground water shows the mean values of $66.0 \mathrm{mg} / l \mathrm{Cl}^{-}, 45.6 \mathrm{mg} / l \mathrm{Ca}^{++}$and 18.5 $\mathrm{mg} / l \mathrm{SiO}_{2}$; the values are much higher than those in the ponds.

\section{i) Yoron-tô Island}

This is a small round-shaped island only $3 \mathrm{~km}$ in diameter lying off the southern extremity of Japan. There are many small artificial ponds on this flat island of

Okinoerabu-jima Island (1958). (A. T. and W. T.: ${ }^{\circ} \mathrm{C}$; dissolved substances : $\mathrm{mg} / \mathrm{l}$ )

\begin{tabular}{rcccccc}
\hline $\mathrm{SO}_{4}$ & $\begin{array}{c}\mathrm{KMnO}_{4} \\
\text { cons. }\end{array}$ & $\mathrm{Ca}$ & $\mathrm{SiO}_{2}$ & $\mathrm{Fe}$ & $\mathrm{PO}_{4}-\mathrm{P}$ & $\mathrm{NH}_{4}-\mathrm{N}$ \\
\hline 8.4 & 45.4 & 38.8 & 11.1 & 0.2 & 0.09 & 0.05 \\
8.4 & 31.6 & 26.0 & 5.4 & 0.0 & 0.5 & + \\
8.4 & 31.6 & 26.7 & 4.2 & 0.1 & 0.6 & + \\
8.4 & 22.8 & 30.0 & 2.4 & 0.0 & 0.2 & + \\
16.8 & 55.3 & 32.0 & 2.4 & 0.0 & 0.0 & + \\
\hline 10.1 & 37.5 & 30.7 & 5.1 & 0.06 & 0.28 & + \\
\hline 13.6 & 20.2 & 28.7 & 23.5 & 0.0 & 0.08 & + \\
23.5 & 22.2 & 62.0 & 24.3 & 0.0 & 1.00 & + \\
8.4 & 15.4 & 35.4 & 2.7 & 0.0 & 0.03 & + \\
17.8 & 11.4 & 56.1 & 15.8 & 0.0 & 0.30 & 0.0 \\
17.6 & 6.9 & 46.0 & 25.9 & 0.0 & 0.07 & + \\
\hline 16.2 & 15.2 & 45.6 & 18.5 & 0.0 & 0.29 & + \\
\hline
\end{tabular}


Table 13. The chemical analyses of the water of the porids on the

\begin{tabular}{rl|c|cccc}
\hline \hline Ponds & Date & A. T. & W. T. & pH & Cl \\
\hline Tame-ike & A & VIII 11 & 33.0 & 35.0 & 8.5 & 69.0 \\
B & $\prime \prime$ & 35.5 & 29.0 & 7.5 & 69.0 \\
C & $\prime \prime$ & 33.0 & 31.0 & 7.2 & 40.5 \\
D & $\prime \prime$ & 31.0 & 33.0 & 9.3 & 29.0 \\
E & $\prime \prime$ & 31.0 & 34.5 & 8.2 & 23.0 \\
F & $\prime \prime$ & 32.0 & 39.0 & 9.8 & 67.0 \\
\hline Mean & & 32.63 & 33.6 & 8.4 & 49.55 \\
\hline
\end{tabular}

coral reefs. Pond $\mathrm{A}$ is situated in the middle of Chabana village and is remarkably contaminated due to domestic drainage. The other ponds lie far from dwelling houses and mostly embanked. In Pond B spring-water wells up; in Pond C Nelumbo nuciferc is cultivated. Because of their proximity to the seashore, all these ponds are exposed to the effects of the sea-breeze, even without the typhonic attacks. Their $\mathrm{pH}$ values showed alkaline; both $\mathrm{Cl}^{-}$and $\mathrm{Ca}^{++}$were found to be large in content.

\section{j) Tomoga-shima Islands}

This is a group of small islands situated at the eastern extremity of the Inland Sea, belonging to Kada-machi, Wakayama pref. The group consists of three islets, namely, Okino-shima, Jino-shima and Kami-jima. Okino-shima has two ponds called Jinja-ike and Jaga-ike, both of which are situated within $30 \sim 40 \mathrm{~m}$ distant from the seashore. Having been invaded by Caldium Mariscus, these two ponds are now turned to small pools or marshes, leaving a small portion of water of the central part. There are Tosadomari-ike pond on the northern coast of Jino-

Table 14. The chemical analyses of the water of the ponds on the Tomogashima Islands. (A.T. and W.T.: ${ }^{\circ} \mathrm{C}$; dissolved substances : $\mathrm{mg} / l$ )

\begin{tabular}{|c|c|c|c|c|c|c|c|c|c|c|}
\hline Ponds & Date & A.T. & W.T. & $\mathrm{pH}$ & $\mathrm{Cl}$ & $\mathrm{SO}_{4}$ & $\begin{array}{c}\mathrm{KMnO}_{4} \\
\text { cons. }\end{array}$ & $\mathrm{Ca}$ & $\mathrm{SiO}_{2}$ & $\mathrm{Fe}$ \\
\hline Jinja-ike & $\begin{array}{l}\mathrm{A} 121 \\
\mathrm{~V} 22\end{array}$ & & & & & & $\begin{array}{r}74.2 \\
114.0\end{array}$ & & & $\begin{array}{l}0.4 \\
0.3\end{array}$ \\
\hline Jaga-ike & $\begin{array}{l}\text { XI } 22 \\
\text { V } 21\end{array}$ & & & & & & & & & $\begin{array}{l}0.3 \\
0.5\end{array}$ \\
\hline Kenno-ike & $\begin{array}{l}\text { XI } 23 \\
\text { V } 22\end{array}$ & $\begin{array}{l}15.9 \\
20.5\end{array}$ & & $\begin{array}{l}4.4 \\
5.4\end{array}$ & & & $\begin{array}{r}42.7 \\
105.0\end{array}$ & & $\begin{array}{l}1.6 \\
8.1=\end{array}$ & $\begin{array}{r}1.0 \\
>10.0\end{array}$ \\
\hline $\begin{array}{l}\text { Cosadomari- } \\
\text { ke }\end{array}$ & $\begin{array}{l}\text { XI } 23 \\
\text { V } 22\end{array}$ & $\overline{21.5}$ & $\begin{array}{l}15.2 \\
24.1\end{array}$ & & 4100.0 & $\begin{array}{l}331.8 \\
200.0\end{array}$ & $\begin{array}{r}42.5 \\
165.0\end{array}$ & & $\begin{array}{l}2.7 \\
7.6\end{array}$ & $\begin{array}{l}0.03 \\
0.5\end{array}$ \\
\hline
\end{tabular}


Yoron-tô Island (1958). (A. T. and W. T.: ${ }^{\circ} \mathrm{C}$; dissolved substances : $\mathrm{mg} / \mathrm{l}$ )

\begin{tabular}{ccccccc}
\hline $\mathrm{SO}_{4}$ & $\begin{array}{c}\mathrm{KMnO}_{4} \\
\text { cons. }\end{array}$ & $\mathrm{Ca}$ & $\mathrm{SiO}_{2}$ & $\mathrm{Fe}$ & $\mathrm{PO}_{4}-\mathrm{P}$ & $\mathrm{NH}_{4}-\mathrm{N}$ \\
\hline 15.5 & 29.0 & 44.7 & 18.4 & 0.5 & 0.06 & 0.005 \\
10.9 & 1.5 & 56.8 & 8.0 & 0.0 & 0.0 & 0.0 \\
10.9 & 5.0 & 28.0 & 4.1 & 0.6 & 0.04 & - \\
11.4 & 9.1 & 26.1 & 2.0 & 0.07 & 0.04 & 0.005 \\
13.6 & 6.9 & 19.3 & 1.9 & 0.1 & 0.0 & 0.005 \\
16.8 & 21.6 & 26.1 & 2.8 & 0.2 & 0.02 & 2.8 \\
\hline 13.2 & 17.85 & 33.5 & 6.2 & 0.25 & 0.03 & 0.45 \\
\hline
\end{tabular}

shima and Kenno-ike pond on Kami-jima. They are situated within only $10 \sim 20 \mathrm{~m}$ distant from the seashore and may permit for sea-water to flow into them at high tide or in a heavy storm. The results of chemical analyses indicate that they are of brackish water. Table 14 shows further data of chemical analyses.

The results mentioned above will be summarised as follows.

1. It is an undeniable fact that the ponds situated near the seashore come under the influence of the surrounding sea. This is especially the case with the ponds on Sadoga-shima and Okino-shima where the monsoon blows so hard. Contrary to expectation, however, neither the monsoon nor the typhoon are found to have much to do with the $\mathrm{Cl}^{-}$content in freshwater ; in other words, these seldom give rise to the increase of $\mathrm{Cl}^{-}$content. Although certain differences of $\mathrm{Cl}^{-}$content are detectable between the two pond groups on the eastern and western. coasts of both Sadoga-shima and Okino-shima; they fully retain the characters of freshwater ponds. The same may be said of all the other ponds sutiuated near the seashore, unless they are invaded by sea water or are in the transitional stage from salt water to fresh water.

2. The two ponds on the Rishiri-tô Is. at high latitude belong to the distinctly dystrophic type, with a brownish water colour, a strong acidity and an abundance of dissolved organic substances. The moor pools on the top of Mt. Hachijô-fuji are quite similar to the ponds in the places of high latitudes, though they are situated in the areas of low latitudes. This is probably due to nearly the same climatic conditions in both districts.

3. The ponds on the Okinoerabu-jima, Yoron-tô and Hachijô-jima have a fairly large $\mathrm{Ca}^{++}$content. Some of them seem to have a gypsotrophic nature, because the former two islands are made up of coral reefs and the latter is volcanic.

\section{B. Plonkton Communities of the Ponds on Each Island}

As mentioned above, the ponds on these islands are of fresh water. even if they are situated close to the seashore, so that the majority of plankton components found in the ponds are freshwater species. In those ponds which, in the 

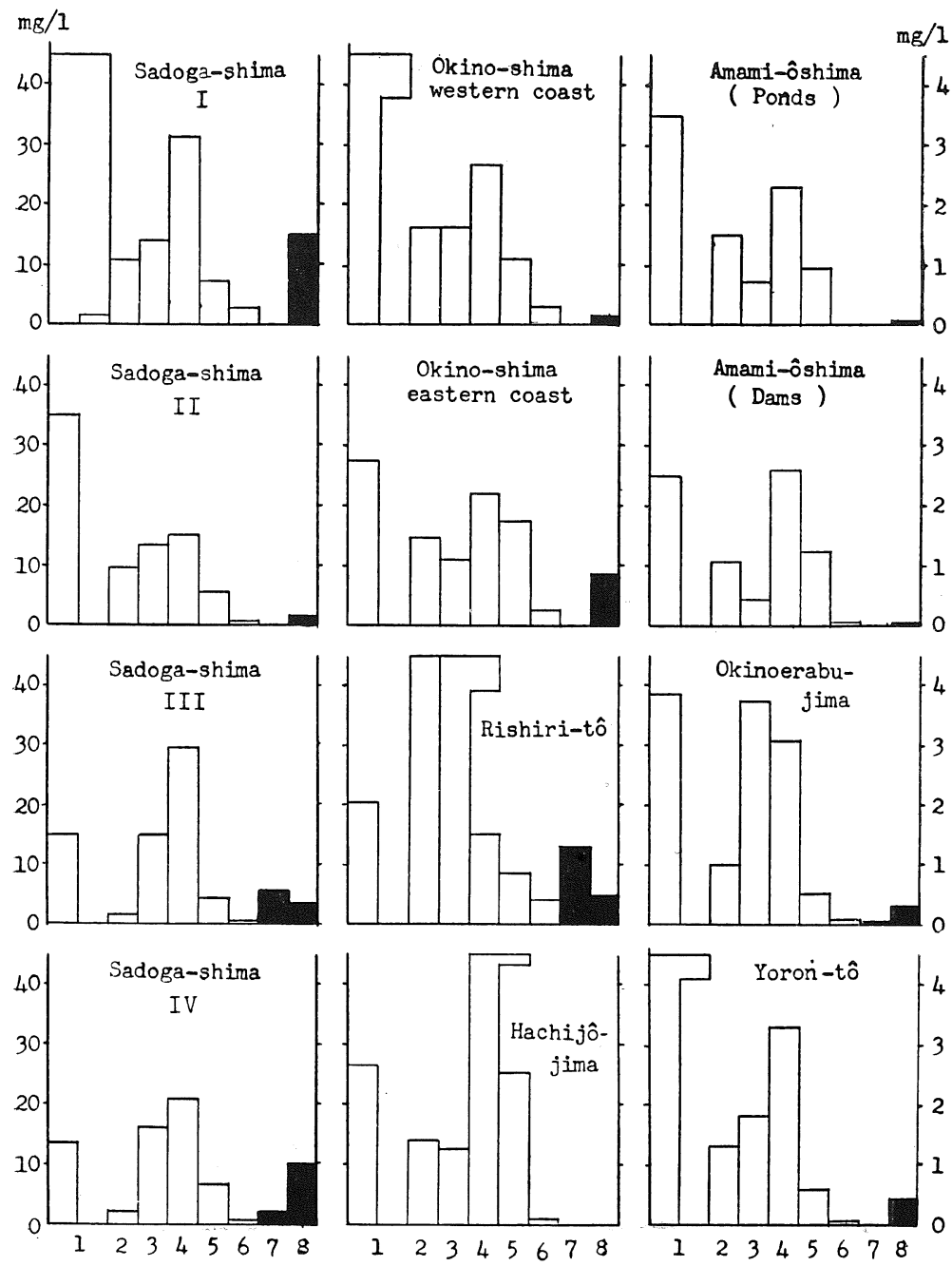

$\square$ See the left scales for $1-6$.

See the right scales for $7-8$.

Fig. 11. Comparison of the dissolved substances in the freshwater ponds on various islands of Japan.

1. Cl-ion, 2. $\mathrm{SO}_{4}$-ion, 3. Consumption of $\mathrm{KMnO}_{4}$,

4. Ca-ion, 5. $\mathrm{SiO}_{2}$, 6. Fe-ion, 7. $\mathrm{PO}_{4}-\mathrm{P}$, 8. $\mathrm{NH}_{4}-\mathrm{N}$. 
former times, were of brackish or sea-water, brackish or marine planktonic species are sometimes found as relics, though omitted the discussion concerning them. The writer's attempt is to discuss the planktonic species from the viewpoint of their habitats upon which the surrounding sea has effected. Fig. 12 is the results obtained by this consideration.

Some species of freshwater plankton are euryhaline and others stenohaline. Among the zooplankton, Copepoda such as Mesocyclops leuckorti and Thermocyclops uénoi, Rotifera such as Kerctella valga, Euchlanis dilatata, Lecane curvicornis, Monostyla bulla and Testudinella patina, and Protozoa such as Difflugia pristis, Arcella vulgcris and others are found to extend their existence range to that of oligohaline or $\alpha$-mesohaline species. Among the phytoplankton, Bacillariophyta such as Fragilaria capusina, $F$. construens, Gomphonema Augur, Pinnularia viridis, P. giboc var. mesogogyla, P. gentilis, Cymatopleura solea, Rhopalodia gibberula and others, and Chlorophyta such as Closterium cornu, Spirogyra sp., Mougeotic sp., Oedogonium sp. and Stigonema minutum seem to be capable of extending their existence range to that of oligohaline or even mesohaline species. As for marine species, however, it is observed that they do not make any invasion into the freshwater basin, the majority of them avoiding to seek their habitats even in the brackish water area. Many diatoms have an extensive existence range and are euryhaline. They are : Melosira nummuloides, M. Borreri, $M$. octogona, Arachnoidiscus Ehrenbergi, Coscinodiscus curvicornis, Tabellaria fenestrata, T. fenestreta var. intermedia, Gyrosigma acuminatum, G. balticum, Pleurosigma compactum, P. angulatum, Nitzschia scalaris, N. paradoxa and others. Some of them, for instance, Tabellaria fenestrata, Nitzschia scalaris, N. paradoxa and others, are often found in freshwaters.

Marine zooplanktonic species are seldom found even within the range of polyhaline species in the brackish water. Some exceptional discoveries, however, were made in this connection in 1956 when the writer, together with FuJishita, investigated the lower reaches of the Yodo River. Among the zooplanktonic species, Colanus minor was found to invade the range of $\beta$-mesohaline species, Calanus tenuicornis to that of polyhaline species and Oithong to that of $\alpha$-mesohaline species. Among the phytoplanktonic species, Skeletonema costatum, Rhizosolenia sp., Chcetoceros decipiens, C. curvisetus, Biddulphia sinensis, Ditylum sol, Eucompia zoodiacus and others were found to invade the range of $\beta$-mesohaline species and Melosira Borreri, Ceratium tripos and $C$. mucronata to invade that of $\beta$-mesohaline species. Accordingly, it is possible to consider that marine planktonic species have less chance of invasion into, and acclimation for, the freshwater ponds cut off from the sea, as compared with the rivers directly connected with the sea.

Sinocalanus tenellus and Brachionus plicatilis, both brackish water species, are found in the range from that of oligohaline species to that of mesohaline species. It may be concluded from these viewpoints that all the pond groups near the seashore are hardly affected by the surrounding sea. Rather it may be noted 


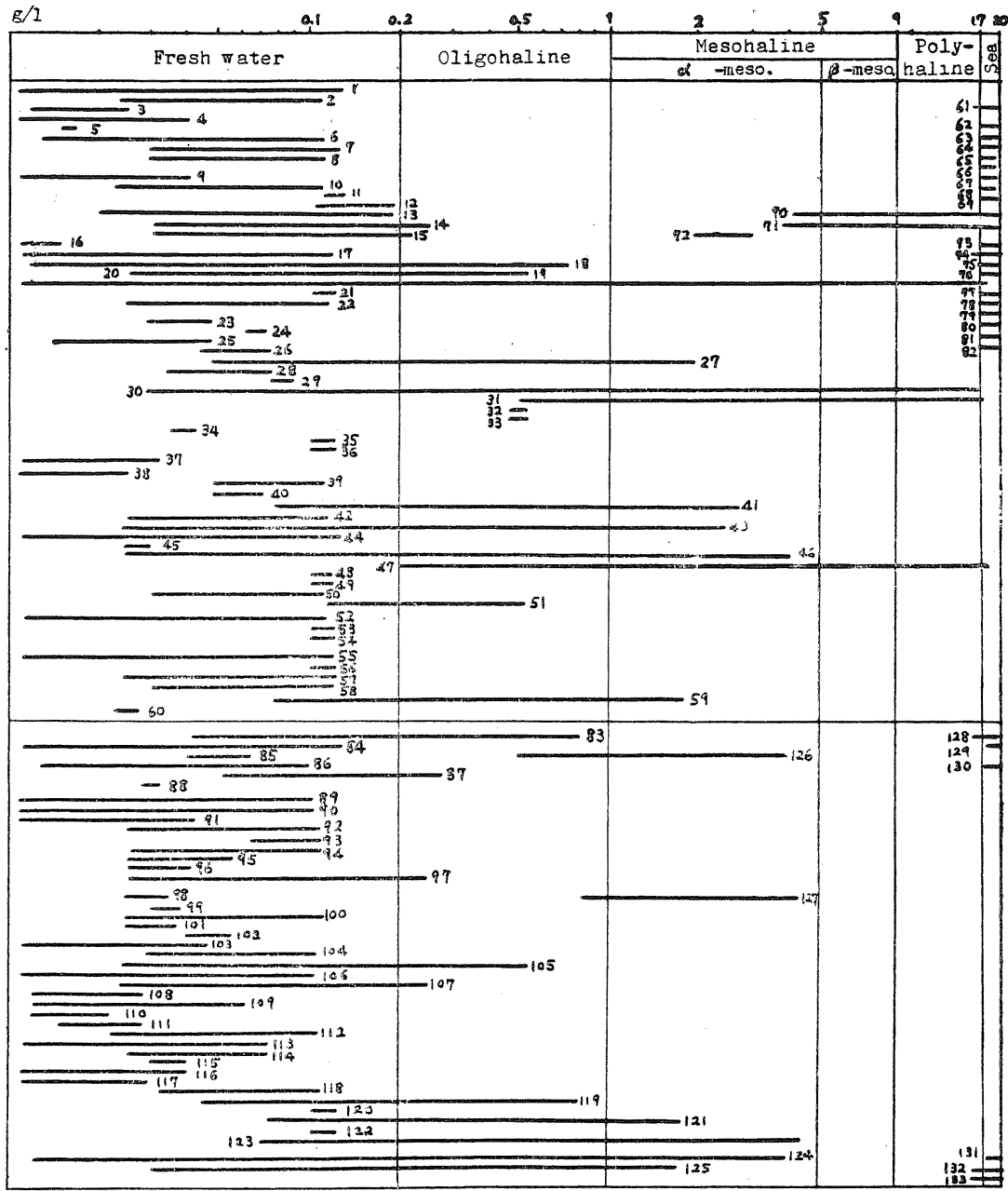

Fig. 12. The existence range of the principal plankton for $\mathrm{Cl}$-ion.

1 Cerctium hirundinellc

2 Peridinium bipes

3 P. cinctum

4 Dinobryon divergens

5 D. barvaricum

6 Euglena viridis

7 Eudorina elegans

8 Phacus longiccuda

9 Melosira itclica
$10 M$. granulcta

$11 M$. varicms

$12 M$. undulats

13 Fragilaria virescens

14. F. capucina

$15 F$. construens

16 Asterionella formosa

17 Synedra ulna

18 S. acus 
Cont. from p. 108.

19 S. tabulata

20 Tabellaria fenestrata

21 T. f. var. intermedia

22 T. flocculosa

23 Navicula angulica

$24 N$. platystoma

25 N. bacillum

26 Diploneis puella

27 D. ovalis

28 Gyrosigma wansbeckii

29 G. distortum var. budensis

30 G. acuminatum

31 G. balticum

32 Pleurosigma compactum

33 P. angulatum

34 Amphorg Normani

35 A. ovalis

36 A. commutata

37 Cymbella affinis

38 C. gracile

39 C. turgida

40 C. tumida

41 Gomphonema Augur

42 G. acuminatum

43 Pinnularia viridis

44 P. gibba

45 Nitzschia sigma

46 N. scolaris

47 N. paradoxa

48 N. filiformis

49 N. spectabilis

50 Rhopalodia gibba

$51 R$. gibberula.

52 Eunotia lunalis

53 E. robusta

54 E. pectinalis

55 Stauroneis fhoenicenteron

56 Neidium affine

57 Surirella robusta

58 S. elegans

59 Cymatopleura solea

60 Frustulia rhomboides

61 Chaetoceros didymis

$62 \mathrm{Ch} . d$. var. protuberans

$63 \mathrm{Ch}$. d. var. anglica

$64 \mathrm{Ch}$. affinis

$65 \mathrm{Ch}$. paradoxum

66 Ch. curvisetus

67 Licmophora sp.

68 Asterionella japonica

69 Thälassiothrix Franenfeldii

70 Coscinodiscus curvicornis

71 Melosira nummuloides

72 M. Borreri

$73 M$. octogona

74 Arachnoidiscus Ehrenbergi

75 Rhizosolenia calcoravis
76 Climacosphenia moniligera

77 Achnanthes brevipes var. intermedia

78 Ceratium tenue

79 C. tripos

80 C. fusus

81 C. masciliense

82 C. macroceros

83 Mesocyclops leuckarti

84 Thermocyclops taihokuensis

85 Eucyclops serrulatus

86 Cyclops vicinus

87 Thermocyclops vénoi

88 Th. hyalinus

89 Diaphanosoma brachyurum

90 Bosmina longirostris

91 Bosminopsis deitersi

92 Alona guttata

93 Graptoleberis mucronata

94 Chydorus sphoericus

95 Moina macrocopa

96 Daphnia longispina

97 D. pulex

98 Brochionus angularis

99 B. forficula

100 B. quadridentatus

101 B. rubens

102 B. calyciflorus

103 Keratella cochlearis

$104 K$. c. var. tecta

$105 K$. valga

106 Pompholyx complanata

107 Euchlanis dilatata

108 Ploesomo truncotum

109 Asplanchna priodonta

110 Conochilus unicornis

111 Platyias sp.

112 Polyarthra euryptera

113 P. trigla

114 Filinia longiseta

115 Trichocerca elongata

116 Tr. cylindrica

117 Tr. capucina

118 Lecane ludwigii

119 L. curvicornis

120 L. luna

121 Monostyla bulla

122 M. hamota

123 Testdinella patina

124 Difflugia sp.

125 Arcello vulgaris

126 Sinocalcmus tenellus

127 Brachionus plicatilis

128 Oithong nang

129 Acartia spinicauda

130 Pcracalanus parvus

131 Favello tarcikcensis

132 Tintinnopsis beroidea

133 T. gracilis 
that freshwater planktonic species tend to invade the brackish water area.

\section{POND GROUPS ON THE COAST OF THE JAPAN SEA}

Owing to the monsoon, winter on the coast of the Japan Sea is the wet season with a good deal of rainfall, while summer there is the dry season with little or no rainfall. In many localities, therefore, ponds are found scattered in considerably large numbers.

a) The Ponds in the Nishi-Tsugaru District, Aomori Pref.

In this district, there are found a number of large ponds arranged in two lines both on the tableland and on the sand-dune, between which is the delta of the Iwaki-gawa River. Both Hirataki-numa and Bense-numa are natural ponds, but the others are typically artificial ponds of dendriform pattern. The ponds on the eastern tableland are especially shallow, and some of them are little different from marshes not only where they branch off but in the very center alike. The $\mathrm{Cl}^{-}$content is around $30 \mathrm{mg} / \mathrm{l}$ in the marshes and ponds among the sand-dune, but in the pond group on the eastern side, Kiyohisa 'tame-ike' pond has the maximum content of $21 \mathrm{mg} / l$, the other ponds ranging from 13.5 to $17.8 \mathrm{mg} / l$. It may be known, therefore, that the pond group on the sand-dune has somewhat a greater $\mathrm{Cl}^{-}$content than the pond group on the eastern tableland due to the effect of the monsoon. It is worthy of note that these ponds have certain characters of bog lakes, having a thick layer of brownish humus deposit on the bottom. Peat is taken up for fuel around the natural pond Hirataki-numa. The colour of their water is brownish, though it is not so strongly brown as in the ponds and marshes on the Rishiri-tô Island and in the northeastern part of Hokkaido. The $\mathrm{pH}$ value is slightly acid or slightly alkaline, the $\mathrm{KMnO}_{4}$ consumption $10 \sim 20 \mathrm{mg} / l$,

Table 15. The chemical analyses of the water of the ponds on the Tsugaru

\begin{tabular}{l|c|cccc}
\hline \multicolumn{1}{c|}{ Ponds } & Date & A. T. & W. T. & pH & Cl \\
\hline Osawanai tame-ike & VIII 4 & 27.2 & 26.5 & 7.1 & 17.8 \\
Fujieda tame-ike & $\prime \prime$ & 27.7 & 27.3 & 7.3 & 17.0 \\
Kiyohisa tame-ike & $\prime \prime$ & 29.3 & 29.8 & 6.7 & 21.0 \\
Ninosawa tame-ike & $\prime \prime$ & 31.0 & 33.0 & 7.0 & 13.5 \\
Bishamon ô-tame-ike & $\prime \prime$ & 30.2 & 38.1 & 6.5 & 16.0 \\
Hakamagata-ike & VIII 5 & 28.0 & 27.6 & 7.4 & 31.2 \\
Ushigata-ike & $\prime \prime$ & 28.0 & 28.2 & 7.7 & 31.6 \\
Tateoka ô-tame-ike & $\prime \prime$ & 31.0 & 32.5 & 7.0 & 29.4 \\
Bensé-numa & $\prime \prime$ & 29.2 & 32.0 & 6.5 & 26.6 \\
Hirataki-numa & $\prime \prime$ & 28.5 & 30.0 & 7.1 & 36.8 \\
\hline
\end{tabular}


with the exception of $55 \mathrm{mg} / l$ in Bensé-numa. It may be said that all these ponds are now in transition from dystrophic waters to a harmonic type. The results of chemical analysis obtained are as shown in Table 15.

b) The Pond Groups on the Coasts of Kisagata and Konoura, Akita. Pref.

On the coast of Konoura there are a few ponds, which are invaded by seawater in part. Both Takeshima-gata and Kannonji-gata are situated about $1 \mathrm{~km}$ away from the seashore. In the Kisagata area the ponds are found not in the low-lying area but on the tableland. Contrary to the expectation that all these ponds may be exposed to the effect of the monsoon from the Japan Sea, the writer failed to observe a remarkable relationship between the amount of $\mathrm{Cl}^{-}$ and the distance from the seashore. The results of chemical analysis obtained. are as seen in Table 16.

c) Pond Groups in the Tottori district

This district is well known for the development of sand-dunes, by the monsoon, among where there are a number of large and small ponds. Both Tôgô-ike and Koyama-ike are large ponds, but it should be better to place them under the category of lakes. Besides being comparatively shallow for their size, they are invaded by the refluent tide in the season of the monsoon, as already pointed out by Yoshimura (1930a) and others. Nikkô-ike, Minajiri-ike and Tanega-ike: are the mediumsized ponds formed naturally in damming up by the sand-dune. The former two can be artificially drained by pumping arrangements, and from spring till autumn the bottoms of them are utilized for the cultivation of rice plants, though water is stored again in winter. Natural ponds there are utilized secondarily as 'tame-ike' ponds. The last-mentioned Tanega-ike lies at the south-

district of Aomori pref. (1960). (A.T. and W.T.: ${ }^{\circ} \mathrm{C}$; dissolved substances : $\mathrm{mg} / l$ )

\begin{tabular}{rrrrrrr}
\hline \hline $\mathrm{SO}_{4}$ & $\begin{array}{c}\mathrm{KMnO}_{4} \\
\text { cons. }\end{array}$ & $\mathrm{Ca}$ & $\mathrm{SiO}_{2}$ & $\mathrm{Fe}$ & $\mathrm{PO}_{4}-\mathrm{P}$ & $\mathrm{NH}_{4}-\mathrm{N}$ \\
\hline 8.0 & 17.1 & 16.0 & 21.7 & 0.7 & 0.0 & 0.1 \\
8.0 & 12.0 & 11.4 & 15.6 & 0.3 & 0.0 & 0.1 \\
13.4 & 23.2 & 20.0 & 3.7 & 0.1 & 0.005 & 0.1 \\
10.0 & 16.4 & 16.0 & 3.9 & 0.1 & 0.0 & 0.1 \\
16.4 & 22.7 & 22.7 & 6.6 & 0.1 & 0.005 & 0.1 \\
10.1 & 6.3 & 28.1 & 10.4 & 0.1 & 0.005 & 0.09 \\
11.8 & 7.6 & 30.1 & 9.5 & 0.1 & 0.005 & 0.1 \\
10.0 & 19.6 & 31.4 & 4.9 & 0.1 & 0.005 & 0.1 \\
16.0 & 55.0 & 29.4 & 5.6 & 0.05 & 0.0 & 0.2 \\
18.5 & 14.5 & 25.4 & 5.4 & 0.05 & 0.005 & 0.1 \\
\hline
\end{tabular}


Table 16. The chemical analyses of the water of the ponds in the Kisagata and Konoura districts of Akita pref. (1959). (A. T. and W. T.: ${ }^{\circ} \mathrm{C} ; \mathrm{Cl}$ and $\mathrm{KMnO}_{4}$ cons. : $\mathrm{mg} / l$ )

\begin{tabular}{|c|c|c|c|c|c|c|}
\hline Ponds & Date & A. $T$. & W. T. & $\mathrm{pH}$ & $\mathrm{Cl}$ & $\begin{array}{c}\mathrm{KMnO}_{4} \\
\text { cons. }\end{array}$ \\
\hline Konoura, beach pond A & VII 31 & 26.5 & 25. 0 & 7.2 & 7400 & 27.9 \\
\hline Konoura, beach pond $\mathrm{B}$ & " & 26.5 & 25.5 & 7.2 & 9500 & 24.0 \\
\hline Takeshima-gata & $" \prime$ & 26.5 & 25.2 & 6.6 & 19 & 14.6 \\
\hline Kannon-gata & $\prime \prime$ & 27.2 & 24.8 & 6.4 & 23 & 220 \\
\hline Tenjin-numa $\mathrm{A}$ & $\prime \prime$ & 28.5 & 25.9 & 6.6 & 27 & 18. 3 \\
\hline Tenjin-numa $B$ & $\prime \prime$ & 28.5 & 26.2 & 6.6 & 31 & 15. 2 \\
\hline Kishiwada-ike A & $\prime \prime$ & 26. 0 & 25.9 & 6.5 & 14 & 17.1 \\
\hline Kishiwada-ike B & " & 25.8 & 26. 2 & 6.0 & 15 & 13. 3 \\
\hline Tame-ike $\mathrm{E}$ & $" 1$ & 24.9 & 23.5 & 5.8 & 14 & 8.9 \\
\hline Tame-ike F & $" \prime$ & 24.9 & 23. 2 & 6.3 & 14 & 11.4 \\
\hline Tame-ike G & $\prime \prime$ & 24.8 & 23.5 & 6.5 & 22 & 17.7 \\
\hline Tame-ike $\mathrm{H}$ & $" 1$ & 24.8 & 23.0 & 6.6 & 16 & 14.6 \\
\hline
\end{tabular}

eastern edge of the Hamasaka Dune. From its geographical position, it seemed to be a bog encircled by the movement of the sand-dune until recent times, but investigations from many viewpoints have now revealed it to be a depressed basin or some such lakes. It is evident, however, that this pond is now being

Table 17. The chemical analyses of the water of the ponds on the Tottori

\begin{tabular}{|c|c|c|c|c|c|}
\hline Ponds & Date & A. $T$. & W. T. & $\mathrm{pH}$ & $\mathrm{Cl}$ \\
\hline Tôgô-ike & XII 27 & 9.5 & 7.8 & 7.0 & 800.0 \\
\hline Koyama-ike & " 29 & 7.5 & 8.1 & 7. 0 & 600.0 \\
\hline Nikkô-ike & " 29 & 13.0 & 10.8 & 6.7 & 400.0 \\
\hline Minajiri-ike & " 29 & 12.0 & 9.2 & 7.3 & 67.0 \\
\hline Tanega-ike & " 30 & 7.0 & 7.0 & 7.1 & 227.0 \\
\hline Maruyama-ike & 1130 & 8.9 & 8.2 & 6.6 & 24.0 \\
\hline Shimohara-ike & " 29 & 8.0 & 6.2 & 6.9 & 37.0 \\
\hline Yahata kita-ike & " 29 & 10.0 & 9.0 & 7.1 & 23. 0 \\
\hline Kidaka beach pond & " 29 & 11.1 & 10. 0 & 6.8 & 44.0 \\
\hline Mitsu-ike & " 29 & 6.0 & 7.9 & 6.8 & 30.0 \\
\hline Shimohôjô pool A & " 27 & 9.7 & 7.4 & 6.2 & 30.0 \\
\hline pool B & " 27 & 10.0 & 7. 0 & 5.4 & 26. 0 \\
\hline pool C & " 27 & 10.5 & 14.0 & 7.0 & 23. 0 \\
\hline
\end{tabular}


reduced area by the movement of the sand-dune on the northern side.

There are many more small ponds, two in Shimohara village, one behind the Yahata Primary School, two near the Yahata Beach, one in Mitsu village, and one called Maruyama-ike in the suburbs of Tottori City. In addition to these, nearly all the vine-yards on the sand-dune around Shimohôjô are provided in the center with an irrigation pool $3 \sim 4 \mathrm{~m}$ square. The results of chemical analysis obtained are shown in Table 17.

Aside from Tôgo-ike and Koyama-ike both of which are brackish ponds, the $\mathrm{Cl}^{-}$content is $200 \mathrm{mg} / \mathrm{l}$ in Nikkô-ike pond and Tanega-ike pond respectively and only $67 \mathrm{mg} / l$ in Minajiri-ike pond. In the other small ponds, its content is reduced to $23 \sim 44 \mathrm{mg} / \mathrm{l}$. Because of the monsoon, the ponds in this district has a tendency to have a greater $\mathrm{Cl}^{-}$content than those on the coastal tablelands of the Inland Sea.

\section{d) Plankton in the Ponds on the Tottori Sand-dunes}

In Tôgô-ike and Koyama-ike there are found some brackish and marine planktonic species, being also collected freshwater ones mixed with them. In the other ponds, however, the majority of plankton is occupied by freshwater species. The planktonic species collected are shown in Table 18.

\section{POND GROUP ON THE INLAND BASINS}

Topographically, the mainland of Japan is traversed in its middle part by coastal sand-dune (1959). (A. T. and W. T.: ${ }^{\circ} \mathrm{C}$; dissolved substances : $\mathrm{mg} / l$ )

\begin{tabular}{rrrrlll}
\hline $\mathrm{SO}_{4}$ & $\begin{array}{c}\mathrm{KMnO}_{4} \\
\text { cons. }\end{array}$ & \multicolumn{1}{c}{$\mathrm{Ca}$} & $\mathrm{SiO}_{2}$ & $\mathrm{Fe}$ & $\mathrm{PO}_{4}-\mathrm{P}$ & $\mathrm{NH}_{4}-\mathrm{N}$ \\
\hline 108.4 & 7.5 & 110.0 & 9.2 & 0.5 & 0.0 & 0.4 \\
254.9 & 7.5 & 30.7 & 4.4 & + & 0.0 & 0.7 \\
\hline 45.4 & 7.5 & 10.4 & 10.0 & 0.5 & 0.05 & 0.6 \\
43.3 & 3.7 & 28.1 & 6.7 & 0.3 & 0.0 & 0.4 \\
10.9 & 1.6 & - & 2.7 & 0.9 & 0.0 & + \\
\hline 7.6 & 4.3 & 6.3 & 4.1 & 2.0 & 0.0 & + \\
23.5 & 2.7 & 14.4 & 3.1 & + & 0.09 & 0.3 \\
16.4 & 12.9 & 14.0 & 6.5 & + & 0.0 & 0.2 \\
22.7 & 2.7 & 23.4 & 13.0 & 0.3 & 0.0 & 0.6 \\
8.0 & 5.9 & 8.0 & 5.0 & + & 0.0 & 0.4 \\
\hline 21.8 & 13.4 & 13.7 & 8.6 & + & 0.01 & 0.4 \\
15.5 & 18.2 & 10.7 & 10.1 & 0.4 & 0.01 & 5.0 \\
57.1 & 5.4 & 37.7 & 3.9 & 0.5 & 0.0 & 0.7 \\
\hline
\end{tabular}


Table 18. Plankton communities of the ponds on the Tottori sand-dune.

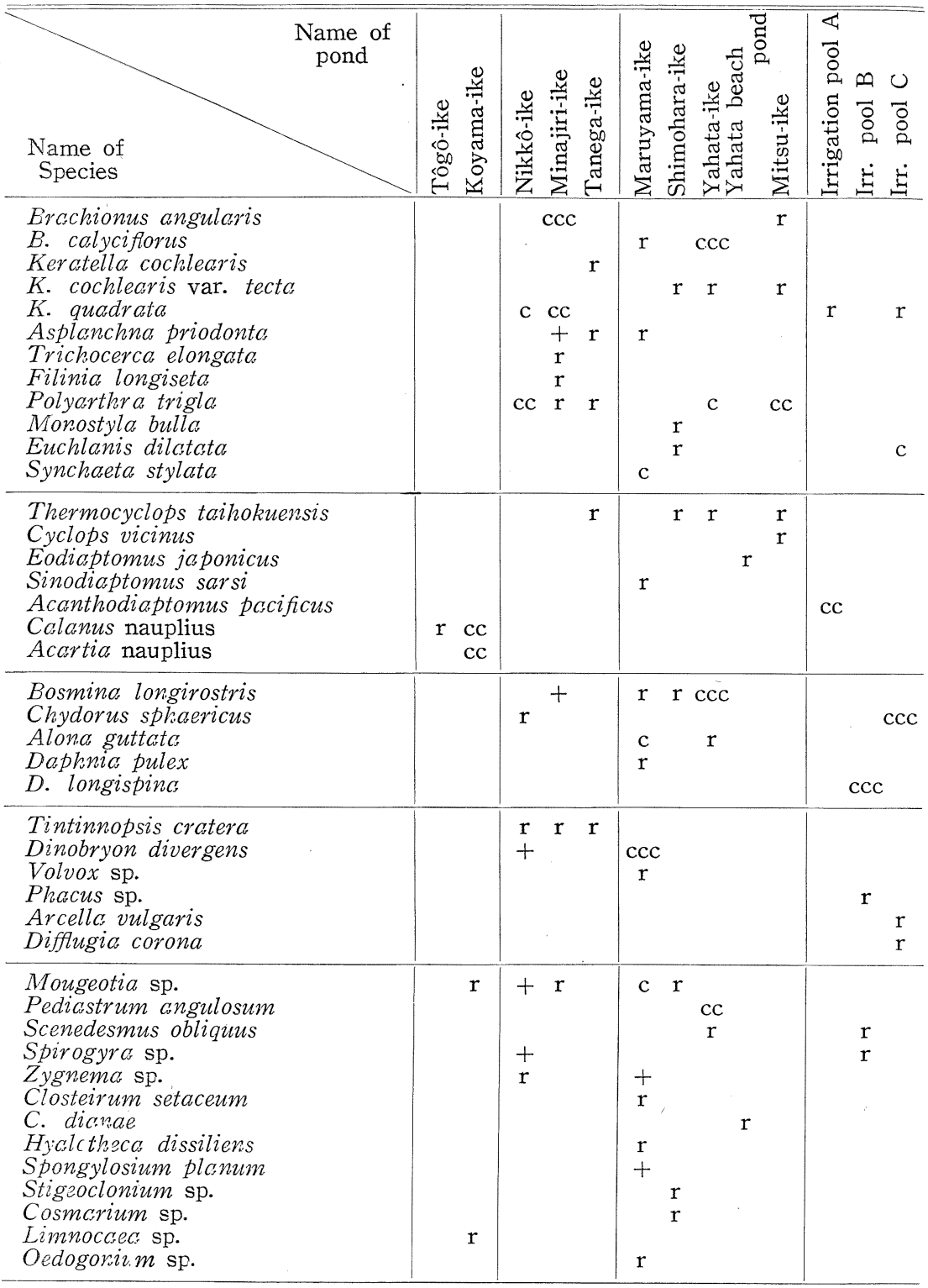




\begin{tabular}{|c|c|c|c|c|c|c|}
\hline $\begin{array}{l}\text { Fragilaria sp. } \\
\text { Melosira varians } \\
\text { M. italica } \\
\text { Bacillaria paradoxa } \\
\text { Pleurosigma fasciola } \\
\text { Gyrosigma sp. } \\
\text { Nitzschia longissima var. reversa } \\
\text { Synedra ulno } \\
\text { S. tcbulata var. acummnata } \\
\text { Navicula placentra } \\
\text { Navicula sp. } \\
\text { Tabellaria fenestrata } \\
\text { Pinnularia gibba } \\
\text { P. viridis } \\
\text { Surirella robusta var. splendida } \\
\text { Epithemia zebra var. saxonica } \\
\text { Stauroneis anceps }\end{array}$ & $\begin{array}{c}\mathrm{c} \\
\mathrm{r} \\
\mathrm{ccc}\end{array}$ & 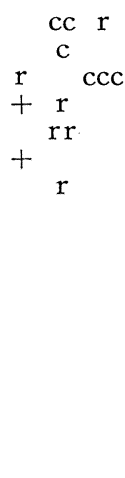 & $\begin{array}{l}\mathrm{r} \\
\mathrm{r} \\
\mathrm{r} \\
\mathrm{r} \\
\\
\mathrm{r} \\
\mathrm{r}\end{array}$ & + & $\mathrm{r}$ & $\mathrm{ccc}$ \\
\hline $\begin{array}{l}\text { Oscillatoria limosa } \\
\text { Microcystis aeruginosa } \\
\text { Anabaena fios-aquae }\end{array}$ & & $\mathrm{r}$ & & $\mathrm{r}$ & & \\
\hline
\end{tabular}

mountain range, among which flat basins are formed here and there. In these basins there are found a fairly large number of irrigation ponds with the well development of agriculture. In the Central District, especially in Nagano pref., there are many lakes, which, from the early days of limnology in Japan, have been the objects of study by many limnologists. Concerning the irrigation ponds, KoIwaI (1940) and UÉNo (1952, 1954, 1958) published their reports. Fish-ponds, too, are now being studied from the standpoint of pisciculture by the staff of Freshwater Fisheries Experiment Stations in various places. In order to make a comparative study of the three different kinds of ponds, insular, coastal and inland, the writer investigated the inland pond groups far away from the coastal line. One of these pond groups is the Shirataka pond group in the Yamagata basin and another is the Kôriyama pond group in the Nara basin.

a) The Chemical Characters and Plankton of the Shirataka Pond Group in Yamagata Basin

This group includes about ten ponds, of which Ô-numa, Naga-numa, Magarinuma, Koke-numa, Are-numa and others are impotant and are found scattered on the tableland west of Yamagata City. Although named 'numa', that is, an English equivalent of marsh, they are really dammed-up ponds in the erosion valleys. These ponds are all free from any artificial contamination and from any effect of sea-breeze, so that the content of $\mathrm{Cl}^{-}$and $\mathrm{SO}_{4}=$ is very slight. The $\mathrm{pH}$ is slightly acid in all cases but the $\mathrm{KMnO}_{4}$ consumption pretty large, its mean value being $26.0 \mathrm{mg} / l$. The bottom mud is composed of humic matters. The layers of peat are found on the shore of Koke-numa ; Brcsenia Schreberi covers the whole surface of Magari-numa. The results of chemical analysis are as 
Table 19. The chemical analyses of the water of the ponds in the suburbs

\begin{tabular}{l|c|cccc}
\hline \hline \multicolumn{1}{c|}{ Ponds } & Date & A. T. & W. T. & pH & Cl \\
\hline O-numa & VII 20 & 25.8 & 24.4 & 6.6 & 4.85 \\
Magari-numa & $\prime \prime$ & 26.2 & 25.9 & 6.4 & 4.85 \\
Koke-numa & $\prime \prime$ & 24.7 & 25.0 & 6.8 & 4.85 \\
Are-numa & $\prime \prime$ & 24.3 & 24.6 & 6.7 & 5.85 \\
\hline Mean & & 25.25 & 24.98 & 6.62 & 5.10 \\
\hline
\end{tabular}

shown in Table 19.

The important planktonic species collected are as follows :

O-numa : The predominant species (zooplankton) are Bosmina longirostris and Bosminopsis deitersi and (phytoplankton) Melosira italica. In addition to them, Thermocyclops sp., Asplanchna priodonta, Ceratium hirundinella, Eudorino elegans, Carchesium polypinum, \&c. are found.

Magcri-numa: The zooplankton species are nearly the same as in Ô-numa, but this pond is characterized by phytoplankton, especially, by the abundance of diatoms, the important species of which are Frustulia rhomboides, Pinnularia microstauron, Melosira italica, Cymbella interupta, followed by Asterionella formosa, Synedra ulna, Cymbella cymbiformis, Gomphonema attenuatum var. coronatum, Tabellaria fenestrata, Eunotia sp., Surillera sp. and others. Among Chlorophyta, Hormidium sp. and Pediastrum araneosum are found ; according to Hirano, Aphonocapsa elachista, Chroococcus dispersus, Trachelomonas hispida, Dictyosphaerium pullchellum, Arthrodesmus extensis, Staurcstrum tetracerum and others appear in this pond in addition to those mentioned above.

Koke-numa: Unlike the afore-named two ponds, the predominant species are Bosmina longirostris, Asplanchna priodonta, Diaphanosoma trachyurum and Ceratium hirundinella. The rotifers such as Polyarthra trigia, Ploesoma truncatum, Notholca acuminata, Lepadella latusinum are also found. Zooplanktonic species are more abundant in this pond than phytoplanktonic ones. Hirano described phytoplankton in this pond as follows : Microcystis aeruginosa, Aphcnocapsa biformis, Dinobryon formosa, Attheya zachariasi, Mellomonas mirabilis, Eudorina elegans, Lagerheima splendens, Golenkinia radiata, Staurastrum dejectum, but the number of individuals is very small in each case except two species of green algae.

Are-numa: This pond is very large in superficies and about 6 meters in depth. The dominant species are Tabellaria fenestrata, Melosira italica under Bacillariophyta, Mougeotia sp. under Chlorophyta, Calothrix sp. under Myxophyta, and except these species, there are found no species especially worthy of note. It is true that Thermocyclops sp., Diaphanosoma brachyurum, Alona guttcta, Ceratium hirundinella, Synedra ulna, Rhosalodia gibba, Cymbella cymbiformis, Gomf honema 
of Yamagata City (1960). (A. T. and W. T.: ${ }^{\circ} \mathrm{C}$; dissolved substances : $\mathrm{mg} / l$ )

\begin{tabular}{rcccccc}
\hline \hline $\mathrm{SO}_{4}$ & $\begin{array}{c}\mathrm{KMnO}_{4} \\
\text { cons. }\end{array}$ & $\mathrm{Ca}$ & $\mathrm{SiO}_{2}$ & $\mathrm{Fe}$ & $\mathrm{PO}_{4}-\mathrm{P}$ & $\mathrm{NH}_{4}-\mathrm{N}$ \\
\hline 8.4 & 22.9 & 23.4 & 8.7 & 0.5 & 0.0 & 0.0 \\
9.2 & 25.5 & 16.6 & 9.5 & 0.3 & 0.0 & 0.03 \\
10.1 & 30.2 & 14.6 & 14.2 & 0.2 & 0.0 & 0.02 \\
5.0 & 25.5 & 13.3 & 4.7 & 0.07 & 0.0 & + \\
\hline 7.67 & 26.02 & 17.0 & 9.27 & 0.27 & 0.0 & 0.01 \\
\hline
\end{tabular}

constricutum and others are also found, though the number of their individuals is very small.

b) Chemical Conditions and Plankton of the Kôriyama Pond Groups in the Nara Basin

The central part of the Nara basin is an area where Japanese culture thrived in olden days. This area, which had few or no rivers, has led to a fairly thick distribution of artificially constructed irrigation ponds. They are mostly square in shape, embanked on all sides like those found in the low-lying districts of Takamatsu and Marugame in Kagawa pref. .They give a unique sight to this flat land area. At the foot of the peripheral mountains in this basin, there are other groups of ponds which were formed by damming up the valleys. Some of these ponds at Kôriyama are utilized for the purpose of fish-breeding.

Having no catchment area for these embanked square-shaped ponds, they are dependent entirely upon rainfall for the storage of water. Furthermore, they are situated far away from the sea and in a flat land surrounded by mountains. It is natural to expect that they are quite free from any effect of the sea. They are however richer in the content of $\mathrm{Cl}^{-}, \mathrm{SO}_{4}=$, and nutritive substances, and has a greater $\mathrm{KMnO}_{4}$ consumption than the pond group at the foot of the peripheral mountains. The $\mathrm{pH}$ value tends to be slightly acid in the former and alkaline in the latter. This may be due to the fact that with the conditions of soil artificial fertilization is done for the purpose of fish-breeding. The ponds in the two different areas mentioned above are characterized by a large content of $\mathrm{Ca}^{++}$.

There occur many plankton species abundantly in the ponds belonging to this group as a result of eutrophication of waters. The dominant species are Brachionus calyciflorus, B. angularis, B. rubens, Polyarthra trigla, Filinia longiseto and Asplanchnc priodonta, all belong to Rotifera, Daphnic pulex and Bosmina longirostris, all Cladocera, Cyclops vicinus, Mesocycio ss leuckarti and Eodiaptomus jabonicus, all Copepoda, and Spirogyra sp. and Oedogonium sp. both of which are assigned to Chlorophyta. In the writer's investigation, Oscillatoria tenuis, Microcystis aeruginosa and $M$. flos-aquae were to be scanty probably due to the 
Table 20. The chemical analyses of the water of the ponds on the Kôriyama

\begin{tabular}{|c|c|c|c|c|c|}
\hline No. of Pond & Date & A. $T$. & W. T. & $\mathrm{pH}$ & $\mathrm{Cl}$ \\
\hline $\begin{array}{r}1 \\
2 \\
3 \\
4 \\
5 \\
6 \\
7 \\
8 \\
9 \\
10 \\
11 \\
12 \\
13 \\
14 \\
15\end{array}$ & 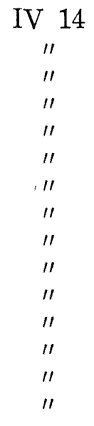 & $\begin{array}{l}17.0 \\
16.2 \\
15.7 \\
15.7 \\
15.0 \\
15.8 \\
15.8 \\
13.8 \\
15.2 \\
15.7 \\
14.8 \\
14.8 \\
15.0 \\
15.1 \\
14.4\end{array}$ & $\begin{array}{l}16.2 \\
16.7 \\
17.0 \\
16.8 \\
16.8 \\
16.0 \\
16.0 \\
16.7 \\
17.0 \\
15.0 \\
15.8 \\
16.0 \\
15.5 \\
15.9 \\
16.2\end{array}$ & $\begin{array}{l}7.4 \\
7.3 \\
5.9 \\
6.6 \\
6.9 \\
7.6 \\
7.0 \\
7.4 \\
8.0 \\
7.8 \\
7.1 \\
8.4 \\
7.0 \\
7.2 \\
9.1\end{array}$ & $\begin{array}{r}16.0 \\
14.0 \\
13.0 \\
14.0 \\
21.0 \\
9.0 \\
8.0 \\
11.0 \\
18.0 \\
10.0 \\
10.5 \\
22.0 \\
12.0 \\
13.0 \\
21.5\end{array}$ \\
\hline Mean & & 15.33 & 16. 24 & 7.38 & 14.53 \\
\hline $\begin{array}{l}18 \\
19 \\
20 \\
21 \\
22 \\
23 \\
24 \\
25 \\
26 \\
27 \\
28 \\
29\end{array}$ & $\begin{array}{c}\text { IV } 15 \\
\text { " } \\
\text { " } \\
\prime \prime \\
\prime \prime \\
\prime \prime \\
\prime \prime \\
\prime \prime \\
\prime \prime \\
\prime \prime \\
\prime \prime \\
\prime \prime\end{array}$ & $\begin{array}{l}18.0 \\
19.0 \\
18.5 \\
17.0 \\
18.5 \\
19.5 \\
18.5 \\
19.5 \\
19.0 \\
16.2 \\
15.5 \\
15.2\end{array}$ & $\begin{array}{l}14.5 \\
15.5 \\
15.0 \\
16.0 \\
15.0 \\
15.5 \\
16.0 \\
14.5 \\
16.0 \\
15.0 \\
15.0 \\
14.5\end{array}$ & $\begin{array}{l}7.2 \\
6.6 \\
6.1 \\
6.9 \\
6.5 \\
6.5 \\
6.7 \\
7.2 \\
7.1 \\
7.1 \\
7.3 \\
7.2\end{array}$ & $\begin{array}{r}6.0 \\
11.5 \\
12.0 \\
6.5 \\
12.0 \\
13.0 \\
12.0 \\
6.0 \\
5.0 \\
3.5 \\
6.0 \\
3.5\end{array}$ \\
\hline Mean & & 17.87 & 15.20 & 6.87 & 8.08 \\
\hline
\end{tabular}

season (spring) that was too early for their multiplication. In the ponds at the foot of the mountains there abound Dinobryon divergens, D. cylindricum, $D$. bavaricum and Melosira italica, all of which have a propensity for an oligotrophic type of ponds, though the same species also occur in the above-mentioned ponds. It is interesting to note that in these ponds of the warm region the boreal species appear in spring.

\section{EXTREMELY CONTAMINATED POND GROUPS}

Generally speaking, the pond groups situated in a plain, on a tableland or at the foot of a mountain are mostly either of an eutrophic or an oligotrophic type. In an urban area or in the suburbs of a city, however, ponds are mostly contaminated by an inflow of domestic drainage, foul water from factories, and fertilizers used for the purpose of fish-breeding. In such ponds, no aquatic plants 
district of Nara pref. (1960). (A.T. and W.T.: ${ }^{\circ} \mathrm{C}$; dissolved substances: $\mathrm{mg} / l$ )

\begin{tabular}{|c|c|c|c|c|c|c|}
\hline $\mathrm{SO}_{4}$ & $\begin{array}{c}\mathrm{KMnO}_{4} \\
\text { cons. }\end{array}$ & $\mathrm{Ca}$ & $\mathrm{SiO}_{2}$ & $\mathrm{Fe}$ & $\mathrm{PO}_{4}-\mathrm{P}$ & $\mathrm{NH}_{4}-\mathrm{N}$ \\
\hline 32.8 & 20.0 & 32.5 & 4.8 & 0.3 & 0.03 & 0.4 \\
\hline 38.6 & 10.8 & 36.3 & 3. 1 & 0.2 & 0.005 & 0.6 \\
\hline 137.3 & 12.1 & 50.8 & 9.3 & 0.3 & 0.03 & 4. 0 \\
\hline 37.0 & 17.6 & 44.1 & 2. 2 & 1. 0 & 0.03 & 0.6 \\
\hline 86.0 & 24.1 & 44.4 & 5.0 & 0.8 & 0.005 & 0.6 \\
\hline 17.6 & 14.1 & 28.1 & 5.6 & 3. 0 & 0.02 & 0.6 \\
\hline 18.5 & 11.4 & 37.9 & 4. 7 & 0.1 & 0.02 & 0.1 \\
\hline 18.9 & 8.0 & 28. 2 & 3.7 & 1. 0 & 0.01 & 0.3 \\
\hline 12.6 & 10.7 & 33.9 & 3.4 & 1. 0 & 0.02 & 0.4 \\
\hline 18.5 & 10.5 & 63.7 & 5.7 & 0.9 & 0.02 & 0.3 \\
\hline 23.1 & 7.9 & 34.7 & 4. 3 & 4. 0 & 0.03 & 0.1 \\
\hline 25.6 & 21.5 & 47.2 & 7.1 & 4.0 & 0.005 & 0.3 \\
\hline 21. 0 & 10.5 & 25.4 & 8. 2 & 0.1 & 0.005 & 0.6 \\
\hline 33.6 & 11.6 & 36.2 & 5.9 & 0.3 & 0.005 & 0.6 \\
\hline 50.8 & 23.7 & 55.6 & 4. 1 & 3. 0 & 0.02 & 1. 0 \\
\hline 38.12 & 14.96 & 39.93 & 5. 14 & 1. 33 & 0.017 & 0.7 \\
\hline 10.5 & 5.7 & 40.9 & 6.6 & 0.8 & 0.03 & 0.3 \\
\hline 16.4 & 17.7 & 26.7 & 1. 8 & 0.8 & 0.03 & 0.1 \\
\hline 18.9 & 5.5 & 32.1 & 4. 6 & 3.0 & 0.02 & 0.6 \\
\hline 16.4 & 7.8 & 28. 0 & 5.8 & 3. 0 & 0.02 & 0.1 \\
\hline 22.7 & 8.9 & 42.1 & 2.3 & 0.9 & 0.02 & 0.7 \\
\hline 23.5 & 5.5 & 34.3 & 4.4 & 0.8 & 0.01 & 2. 0 \\
\hline 13.9 & 7.9 & 38.1 & 1.5 & - & 0.005 & 2. 0 \\
\hline 13.0 & 5.7 & 42.9 & 6.2 & - & 0.005 & 3. 0 \\
\hline 16.4 & 6.1 & 49.0 & 4.8 & - & 0.005 & 4.0 \\
\hline 11.8 & 5.0 & 23.5 & 7.8 & - & 0.005 & 0.6 \\
\hline 12.6 & 5.5 & 29.5 & 7.1 & - & 0.005 & 0.7 \\
\hline 12.6 & 3.7 & - & 4.6 & 一 & 0.005 & 4.0 \\
\hline 15.72 & 6.67 & 35.19 & 4. 79 & 1.55 & 0.013 & 1.5 \\
\hline
\end{tabular}

are found growing, with a blackish water colour and an offensive smell, though there are some clear ponds which are transparent to the very bottom. There are found no living organisms in these ponds, but actually a number of planktonic species can be collected by means of a plankton-net. In most cases, the number of species is extremely limited and just a few species adaptive to such environments are dominant. The results of chemical analysis obtained are as shown in Table 20.

\section{a) Chausuyama-ike at Tennôji in Osaka City}

This pond is 2 meters in depth, black in water-colour, and has a thick layer of black mud in the bottom. It is remarkably polluted by the constant inflow of domestic drainage from the dwelling houses in the neighbourhood. The dominant species in it are blue-green algae such as Microcystis aeruginosa, Anabaena flos-aquae, Anabaena sp., and small green algae such as Scenedesmus sp. 
Table 21. The principal planktonic species in the pond groups at Kôriyama in Nara Prefecture.

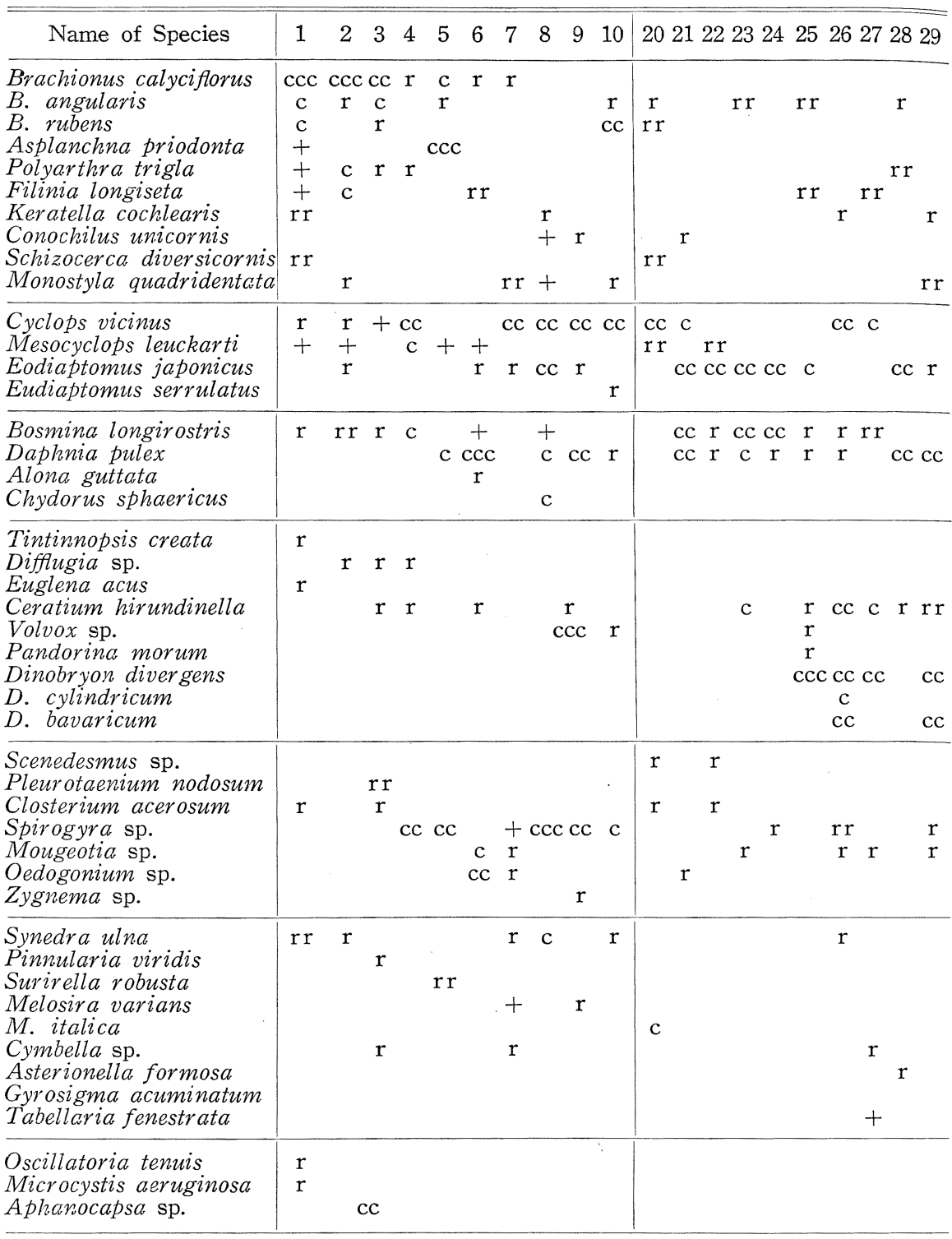


and Micractinium sp., the "water-bloom" being formed. The $\mathrm{pH}$ value shows strongly alkaline all the year round.

\section{b) Ponds on the Low-lying and Damp Area in Amagasaki City}

Amagasaki is an industrial city built in a low-lying and damp locality near Osaka; there still remain a number of ponds in the city area. The water-surface of these ponds is at the level of the ground ; therefore, they are affected by an inflow of domestic drainage, having no ill effect of the direct inflow of water from the neighbouring paddy-fields. They have been no longer drained for the purpose of paddy-field irrigation. At present, they have a tendency to become shallow and are filled up not only with a result of the invasion of aquatic plants, Zizania latifolia, Typha orientalis and Phragmitis communis encircling them, but also with the piling up of sand, mud and the deposit of dirt carelessly dumped into them. With the exception of pond No. 2 at Amagasaki, all the ponds are strongly alkaline and the content of ions such as $\mathrm{Cl}^{-}, \mathrm{SO}_{4}=, \mathrm{Ca}^{++}, \mathrm{SiO}_{2}, \mathrm{Fe}^{++}, \mathrm{PO}_{4} \equiv, \mathrm{NH}_{4}^{+}$, and also the consumption of $\mathrm{KMnO}_{4}$ are all extremely large. For instance, pond No. 3 at Amagasaki shows the content of $\mathrm{SO}_{4}=436.8 \mathrm{mg} / l$, that of $\mathrm{PO}_{4} \equiv 21.4$ $\mathrm{mg} / l$, that of $\mathrm{NH}_{4}{ }^{+} 200 \mathrm{mg} / l$ and the $\mathrm{KMnO}_{4}$ consumption $151.0 \mathrm{mg} / l$; and pond No. 4 the content of $\mathrm{Cl}^{-} 197 \mathrm{mg} / l$, and $\mathrm{NH}_{+}{ }^{+} 16 \mathrm{mg} / l$. In addition to the zooplankton such as Brachionus calyciflorus, B. rubens, B. qucdridentatus, Moina macrocopa, Diaphanosoma brachyrum and Mesocyclops leuckarti, flagelates, ciliates and blue-green algae, all of which have a propensity for contaminated ponds, are found to be dominant in these ponds. The colour of water, therefore, is from yellow to green in the shades.

\section{c) Ponds Contaminated by Polluted Waters from Factories}

Pond No. 1 at the Tsuchiyama area, Hyôgo pref. has a great deal of white lime-like residue thrown in from the neighbouring small workshops. The water of the pond is transparent, but no aquatic plant and plankton are found there. The $\mathrm{pH}$ is strongly acid, with its value 3.0 , and $\mathrm{SO}_{4}=185 \mathrm{mg} / \mathrm{l}$ or more. This is probably due to inorganic substances dissolved in the pond water.

The pond which is situated at the western extremity of Osaka City and is polluted by foul water from the Tanabe Medicine Manufactory shows a blackish water-colour and gives off an offensive medicine smell, bubbles ceaselessly rising from the bottom. It is said that there once used to keep tortoises and fishes, but they disappear no longer there. The $\mathrm{pH}$ value is $6.7, \mathrm{SO}_{4}=94.1 \mathrm{mg} / l, \mathrm{KMnO}_{4}$ consumption $78 \mathrm{mg} / l, \mathrm{Fe}^{++} 9.0 \mathrm{mg} / l$ and $\mathrm{NH}_{4}{ }^{+} 45 \mathrm{mg} / l$. As compared with ordinary ponds, it is evident that organic substances are dissolved in large quantities in this pond water. Although scantily, however, such planktonic species as Eodiastomus japonicus, Bosmina longirostris, Brachionus angularis and others are found, and Euglena viridis and Trachelomonus, both of which are indicators of polysaprobic water, are dominant. Bacteria are also plentiful.

In the pond polluted by foul water from the Kanai Piano Wire Manufactory 
Table 22. The chemical analyses of the water of remarkably contaminated

\begin{tabular}{|c|c|c|c|c|}
\hline Ponds & Date & A. $T$. & W. T. & $\mathrm{pH}$ \\
\hline Chausuyama-ike pond in Osaka City & VI 18 & 23. 0 & 24.8 & 9.8 \\
\hline Pond No. 2 at Amagasaki City & " 12 & 25.5 & 25.0 & 6.6 \\
\hline Pond No. 3 at Amagasaki City & " 12 & 26. 0 & 29.0 & 7.9 \\
\hline Pond No. 4 at Amagasaki City & " 12 & 26.0 & 28.0 & 7.8 \\
\hline Gold-fish culture pond A at Kôriyama & IV 15 & 15. 0 & 13.5 & 9.8 \\
\hline Gold-fish culture pond B at Kôriyama & " 15 & 15.0 & 15.0 & 7.1 \\
\hline Hyôtan-ike at Kushiro City, Hokkaido & VIII 24 & 20.0 & 20.2 & 7.3 \\
\hline Pond No. 1 at Tsuchiyama & XI & 18. 0 & 16. 0 & 3. 0 \\
\hline Tanabe-seiyaku pond in Osaka City & VI 12 & 24.3 & 25. 0 & 6.7 \\
\hline Kanai-jûkô pond at Amagasaki City & VII 6 & 30.7 & 31.3 & 3.5 \\
\hline Tôa-woodpulp pond A at Amagasaki City & '" & 29.5 & 29.0 & 6.9 \\
\hline Tôa-woodpulp pond B at Amagasaki City & $"$ & 29.5 & 30.2 & 7.3 \\
\hline Meiji-penicillin pond at Amagasaki City & $\prime \prime$ & 28. 2 & 28. 0 & 7.4 \\
\hline
\end{tabular}

there is seen a deposit of ferric oxide, the surrounding ground being tinged reddish brown. $\mathrm{Fe}^{++}$is found to be $18 \mathrm{mg} / l$, and the $\mathrm{pH}$ shows strongly acid at 3.5 . In regard to the other dissolved substances, $\mathrm{Cl}^{-}$is $310 \mathrm{mg} / l, \mathrm{SO}_{4}=53.8 \mathrm{mg} / l$, $\mathrm{KMnO}_{4}$ consumption $80.6 \mathrm{mg} / l, \mathrm{Ca}^{++} 61.5 \mathrm{mg} / l$ and $\mathrm{NH}_{4}{ }^{+} 80.0 \mathrm{mg} / l$; the characters of the water are very extraordinary. Brachionus rubens and Navicula sp. alone appear abundantly. The other species found scantily now ; they are: Hormidium sp., Ceratium hirundinella and Nitzschia palea.

The two ponds on the western side of the Tôa Pulp Manufactory and a small pond on the southern side of the Meiji Penicillin Manufactory show a blackish colour, giving off an offensive smell, though no direct inflow of foul water. They are perhaps the most polysaprobic ponds, but unlike pond No. 1 at the Tsuchiyama area and the pond near the Kanai Piano Wire Manufactory, they are polluted by infiltrated organic substances, and therefore, polytrophic planktonic species are predominant. They are : Chroococcus sp., Pleurocapsa varia, Ankistrodesmus falcatus, Euglena viridis, Merismopedia convoluta, Phacus longicauda, Trachelomonas sp., Closteriopsis longissima and other small ciliates, though Brachions calyciflorus, Moina macrocopa, Asplanchna priodonta, Mesocyclops leuckarti and others are also found there.

\section{d) Gold-fish Breeding Ponds at Kôriyama}

These are very shallow and artificially constructed ponds, with the depths of $0.3 \sim 0.5 \mathrm{~m}$. To carry on an intensive gold-fish breeding, the ponds are fertilized. The $\mathrm{pH}$ value in pond $\mathrm{B}$ was 7.1 soon after a fertilization and that in pond $\mathrm{A}$ investigated quite a number of days after the fertilization was $>9.8 . \mathrm{Cl}^{-}, \mathrm{SO}_{4}{ }^{2}$, 
1961]

陸氷学 雑誌

ponds in various area (1960). (A.T. and W.T.: ${ }^{\circ} \mathrm{C}$; dissolved substances : $\mathrm{mg} / \mathrm{l}$ )

\begin{tabular}{rrrrrrrrr}
\hline \multicolumn{1}{c}{$\mathrm{Cl}$} & $\mathrm{SO}_{4}$ & $\begin{array}{r}\mathrm{KMnO}_{4} \\
\text { cons. }\end{array}$ & $\mathrm{Ca}$ & $\mathrm{SiO}_{4}$ & $\mathrm{Fe}$ & $\mathrm{PO}_{4}-\mathrm{P}$ & $\mathrm{NH}_{4}-\mathrm{N}$ & $\mathrm{NO}_{3}-\mathrm{N}$ \\
\hline 32.0 & 71.4 & 20.8 & 35.1 & 1.2 & 0.5 & 0.0 & 0.6 & - \\
33.5 & 63.0 & 20.2 & 26.1 & 1.0 & 4.0 & 0.01 & 0.01 & - \\
69.5 & 436.8 & 151.0 & 48.8 & 12.0 & 5.0 & 21.0 & 200.0 & - \\
197.5 & 65.5 & 25.7 & 50.1 & 14.0 & 3.0 & - & 16.0 & - \\
45.0 & 33.6 & 74.8 & 53.6 & 9.1 & 1.0 & 2.5 & - & - \\
60.0 & 17.2 & 68.6 & 47.8 & 1.5 & 0.8 & 0.7 & 7.0 & $>20.0$ \\
39.0 & 23.0 & 3.2 & 51.0 & 12.5 & 0.0 & 0.0 & 0.9 & 0.2 \\
54.0 & 185.0 & 2.2 & 47.4 & 1.1 & 2.0 & 0.0 & 1.0 & - \\
20.5 & 94.1 & 78.4 & 21.4 & 11.0 & 9.0 & 0.4 & 45.0 & - \\
310.0 & 53.8 & 80.6 & 61.5 & 8.5 & 18.0 & 0.0 & 80.0 & - \\
49.0 & 25.2 & 37.3 & 39.4 & 1.4 & 2.0 & 0.3 & 2.0 & - \\
43.0 & 18.5 & 45.1 & 61.5 & 8.2 & 20.0 & 0.07 & 0.9 & - \\
770.0 & 72.2 & 207.6 & 199.1 & 17.0 & 4.0 & 2.0 & 60.0 & - \\
\hline
\end{tabular}

$\mathrm{Ca}^{++}, \mathrm{NH}_{4}^{+}$and $\mathrm{KMnO}_{4}$ consumption indicate large figures without exceptions. Zooplanktonic species are scanty. Phytoplanktonic species are plentiful, with such important species as Scenedesmus quadricauda, S. obliquus, S. bijuga, Actinastrum hantzschii var. fluviatile, Coelastrum sphaericum, Pediastrum boryanum, Tetraedron hastatum var. platium, Schroederia setigera, Closteriopsis longissima, Microcystis aeruginosa and others.

\section{e) A Pond in Kushiro City}

There is a small pond called 'Hyôtan-ike' in a park in Kushiro City, Hokkaido. The pond is extraordinarily contaminated by inflowing water from the Zoological Garden around it. The $\mathrm{pH}$ value is 7.3 , but the amount of $\mathrm{Cl}^{-}$and $\mathrm{NO}_{3}{ }^{-}$are conspicuously large. The predominant species are Keratella cochlearis var. irregularis, Brachionus quadridentatus as zooplankton, and Melosira italica as phytoplankton. There occur also Brachionus angularis, Polyarthra trigla, Closterium gracile var. elongata, Pediastrum boryanum, Anabaena fos-aquae, \&c.

\section{THE DIURNAL FLUCTUATION OF PHYSICAL AND CHEMICAL CONDITIONS AND PLANKTON COMMUNITIES}

In the preceding chapters, the characteristics of several ponds have been described on the basis of both regional and environmental considerations. The following chapter is intended mainly for the elucidation of the diurnal fluctuations 
which affect the characters of some particular ponds.

It is well known that the most remarkable diurnal fluctuations in this connection are those of $\mathrm{pH}$ values and water temperatures. Not seldom do we also take notice that the surface water of a pond changes its colour according to whether algae come up or go down. This makes us presuppose that, besides the physical and chemical fluctuations, there may possibly take place some positional shifts of plankton in the pond waters.

A small freshwater lake at the Cape of Good Hope was investigated by SнÜтTE and Elsworth in 1954 as to how $\mathrm{pH}$ value in it changed in the course of one day. WEIMANN (1943) stated that the changes of water temperature, $\mathrm{pH}$ value and dissolved $\mathrm{O}_{2}$ content in the course of a whole day and night could be almost equal in effect to their seasonal fluctuations of a whole year's duration; he made an attempt at the classification of ponds according to the diurnal fluctuations of dissolved $\mathrm{O}_{2}$ content. In Japan, too, studies in this connection were done by Kurashige (1931), Kurashige \& Kagei (1932) and M. Watanabe (1932), but reports on such diurnal fluctuations have been extremely few. The writer, therefore, selected three ponds of different types in the suburban areas of Osaka-one at Chausuyama Heights which was strongly contaminated and of an eutrophic type, another at Kôyôen which, situated in a mountain, was of an oligotrophic type, and still another at Itami which, lying on a tableland, was of a mesotrophic type. The results obtained are shown in Fig. 13.

Table 23. The planktonic species in the ponds contaminated by polluted water.

\begin{tabular}{|c|c|c|c|c|c|c|}
\hline Name of pon & 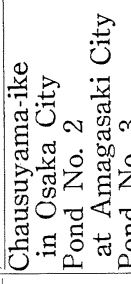 & 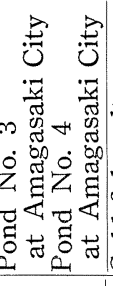 & 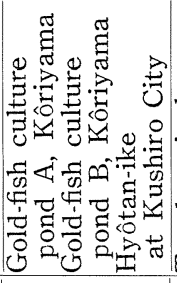 & 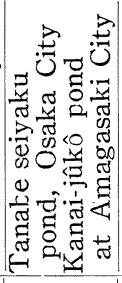 & 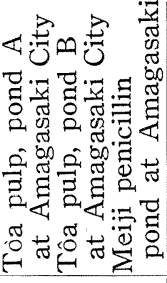 & 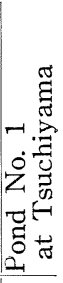 \\
\hline $\begin{array}{l}\text { Brachionus rubens } \\
\text { B. quadridentatus } \\
\text { B. calyciflorus } \\
\text { B. angularis } \\
\text { Keratella cochlearis } \\
\text { Asplanchna priodonta } \\
\text { Rotaria sp. } \\
\text { Diurella siylata } \\
\text { Pompholyx complanata } \\
\text { Monostyla bulla } \\
\text { Polyarthra trigla }\end{array}$ & + & $\begin{array}{cc}\mathrm{c} & \mathrm{cc} \\
& \mathrm{c} \\
\mathrm{cc} & \\
& \mathrm{rr} \\
& \mathrm{r}\end{array}$ & $\begin{array}{l}\mathrm{cc} \\
+ \\
\mathrm{cc}\end{array}$ & $\mathrm{rr}$ & $\begin{array}{ll}\mathrm{r} & \mathrm{cc} \\
+ & \\
\mathrm{r} & \\
\mathrm{r} & \\
\mathrm{r} & \end{array}$ & \\
\hline $\begin{array}{l}\text { Mesocyclops leuckarti } \\
\text { Eodiaptomus japonicus } \\
\text { Thermocyclops sp. }\end{array}$ & $\mathrm{r}$ & $\operatorname{ccc}$ & & & $+\mathrm{cc}$ & \\
\hline
\end{tabular}




\begin{tabular}{|c|c|c|c|c|c|c|c|c|c|c|c|}
\hline $\begin{array}{l}\text { Moina macrocopa } \\
\text { Bosmina lonigrostris } \\
\text { Diaphanosoma brachyurum } \\
\text { Chydorus sphaericus }\end{array}$ & & $\begin{array}{l}\mathrm{r} \\
\mathrm{r}\end{array}$ & & & & & $\mathrm{r}$ & & & $\mathrm{cc}$ & \\
\hline $\begin{array}{l}\text { Ceratium hirundinella } \\
\text { Phacus longicauda } \\
\text { Euglena acus } \\
\text { E. viridis } \\
\text { Trachelomonas spp. } \\
\text { Gimnodinium sp. } \\
\text { Vorticella sp. }\end{array}$ & & $\begin{array}{l}\mathrm{c} \\
\mathrm{r} \\
\mathrm{c} \\
\mathrm{r}\end{array}$ & & & $\mathrm{r}$ & & $\begin{array}{l}\mathrm{r} \\
\mathrm{r}\end{array}$ & $\mathrm{r}$ & $\begin{array}{l}\mathrm{r} \\
\mathrm{r} \\
\mathrm{cc}\end{array}$ & c & \\
\hline $\begin{array}{l}\text { Melosira italica } \\
\text { Navicula cryptocephala } \\
\text { Nitzschia palea } \\
\text { N. sigmoidea } \\
\text { Stauroneis gracile }\end{array}$ & & & & & & $\mathrm{cc}$ & & $\begin{array}{c}\mathrm{ccc} \\
\mathrm{r}\end{array}$ & & $\begin{array}{c}\mathrm{ccc} \\
\mathrm{r}\end{array}$ & $r$ \\
\hline $\begin{array}{l}\text { Schroederia stigera } \\
\text { Tetraedron hastatum } \\
\text { Planktosphaeria gelatinosa } \\
\text { Dimorphococcus lunatus } \\
\text { Chloococcus sp. } \\
\text { Pleurocapsa varia } \\
\text { Micractinium pusillum } \\
\text { Spirogyra sp. } \\
\text { Ulothrix sp. } \\
\text { Masotaenium Greyii } \\
\text { Closterium longissima } \\
\text { Selenastrum gracile } \\
\text { Coelastrum sphaericum } \\
\text { Actinastrum Hantzschii } \\
\text { Pediastrum boryanum } \\
\text { P. biwae } \\
\text { Microspora sp. } \\
\text { Scenedesmus quadricauda } \\
\text { S. obliquus } \\
\text { S. tijuga } \\
\text { Ankistrodesmus falcatus }\end{array}$ & $\begin{array}{c}\mathrm{r} \\
\mathrm{cc} \\
\mathrm{c} \\
\\
\mathrm{c} \\
\\
\\
\mathrm{r} \\
+ \\
\mathrm{r} \\
\mathrm{r} \\
\\
\mathrm{cc} \\
\mathrm{cc} \\
\mathrm{c}\end{array}$ & $\mathrm{rr}$ & & & 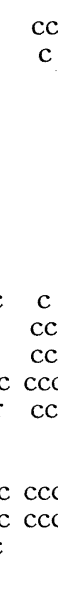 & $\mathrm{r}$ & $\underset{\mathrm{r}}{\mathrm{rr}}$ & & & $\begin{array}{l}\mathrm{c} \\
\mathrm{c} \\
\mathrm{r} \\
\mathrm{r} \\
\mathrm{r}\end{array}$ & \\
\hline $\begin{array}{l}\text { Microcystis aeruginosa } \\
\text { Oscillatoria limosa } \\
\text { Anabaena flos-aquae }\end{array}$ & $\begin{array}{l}\mathrm{ccc} \\
\mathrm{cc}\end{array}$ & & & 1 & & $r$ & & & & & \\
\hline
\end{tabular}


Chausuyama-ike

Ttami-shimo-ike

Kôyjen No. 202 pond

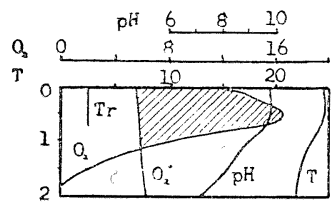

$16: 00$
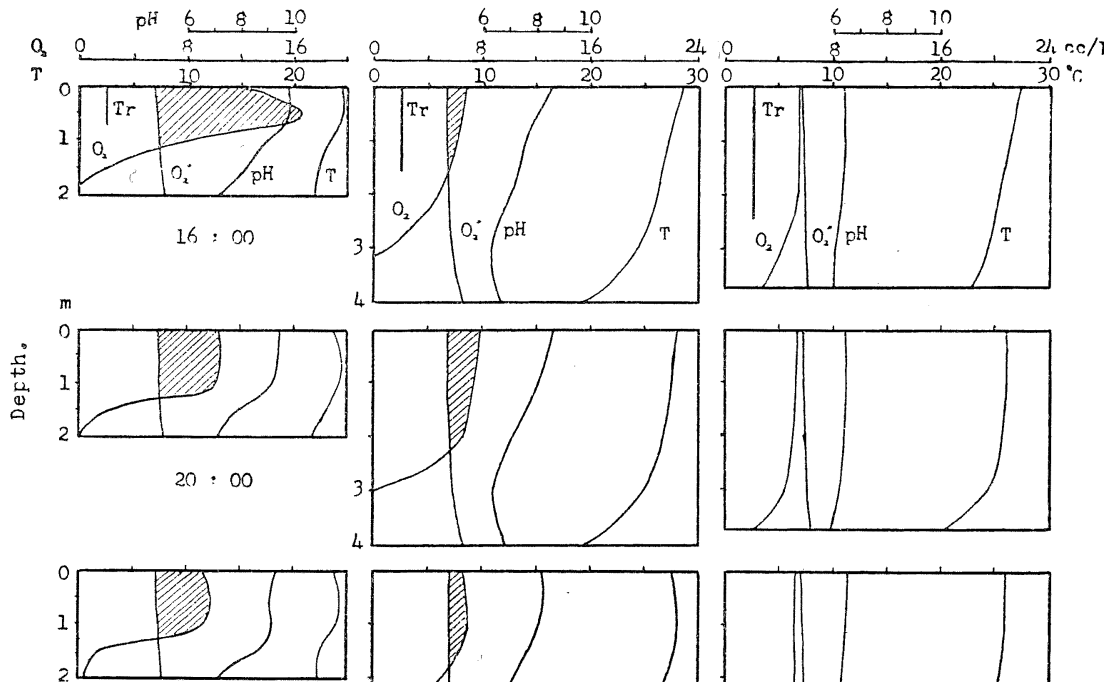

$24: 00$
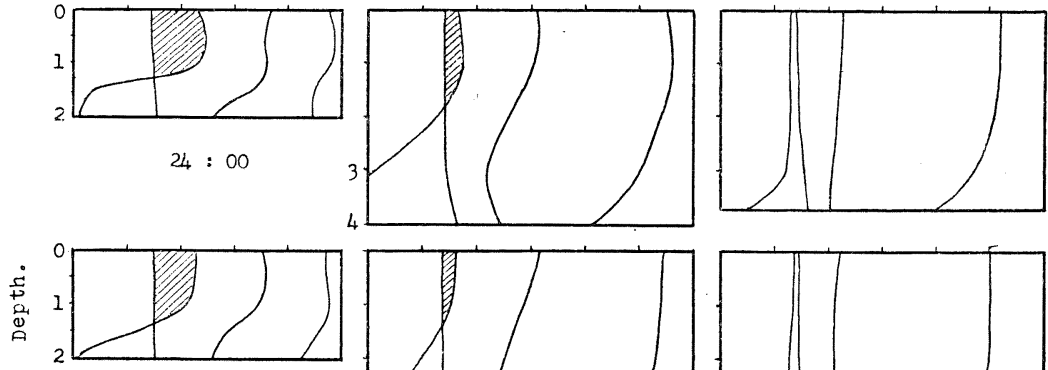

$4: 00$
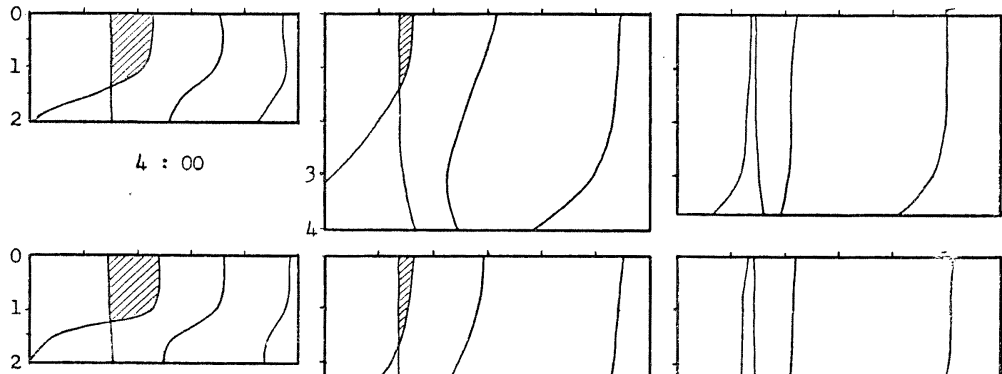

$8: 00$
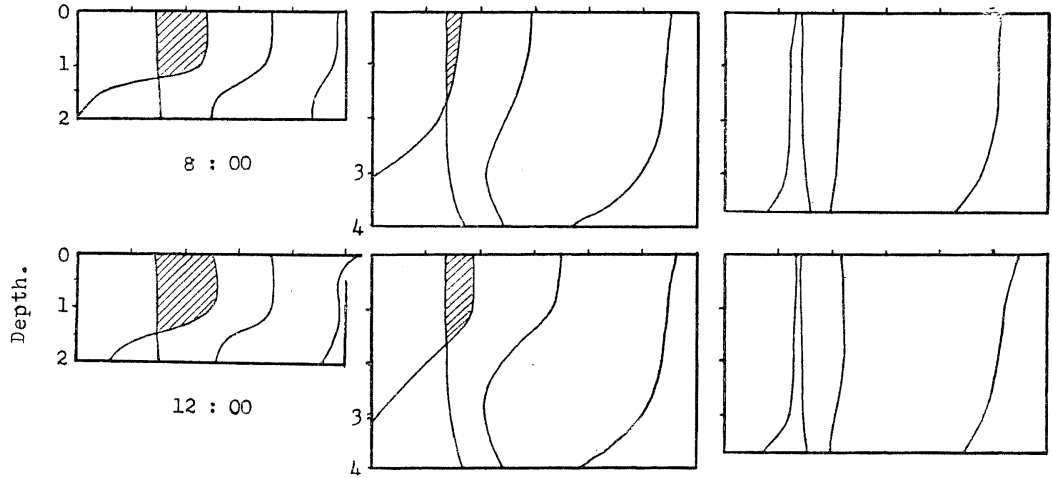

Fig. 13. The diurnal fluctuation of the water temperature, the hydrogen-ion concentration and the dissolved $\mathrm{O}_{2}$.

$\mathrm{T}$ : Water temperature, $\mathrm{O}_{2}$ : dissolved Oxygen $(\mathrm{cc} / l)$, $\mathrm{O}_{2}{ }^{\prime}$ : saturation of $\mathrm{O}_{2}(\mathrm{cc} / l)$, Tr. : Transparency 


\section{THE VERTICAL AND DIURNAL FLUCTUATIONS OF PHY- SICAL AND CHEMICAL CONDITIONS}

\section{a) Pond at Chausuyama. Heights at Tennôji in Osaka City}

The depth of water is 2 meters. Having been contaminated by the sewage flowing in from the surrounding dwelling houses, Microcystis, Scenedesmus and the like were found growing in abundance. The water-colour is deep green.

Water temperature : The water temperature at the surface layer is $26.0^{\circ} \mathrm{C}$ at its maximum and $23.7^{\circ} \mathrm{C}$ at its mininum, the difference between the two being $2.3^{\circ} \mathrm{C}$. The difference at the bottom was found to be $0.9^{\circ} \mathrm{C}$ lower on the average than that at the surface. Hardly any difference could be detected in the vertical distribution of temperature, as the pond was not deep enough.

pH : The surface layer remained alkaline all day long, showing its maximum. $\mathrm{pH}$ value of 9.8 at $16: 00$ and its minimum $\mathrm{pH}$ value of 9.0 at $4: 00$ before dawn. After sunrise, it was found to go up again. Its vertical distribution showed the same value as above at the $0 \sim 1 \mathrm{~m}$ layer but a rapid decrease from the $1.5 \mathrm{~m}$ layer downward to the $2 \mathrm{~m}$ layer turned out neutral, with its $\mathrm{pH}$ value reduced to 7.2 or 7.0 . This indicated the presence of a water layer different in its chemical condition. The diurnal fluctuations were comparatively slight.

Dissolved $\mathrm{O}_{2}$ : The surface $0 \sim 0.5 \mathrm{~m}$ layer showed an extraordinary supersaturation of more than $200 \% \mathrm{O}_{2}$ at 16:00, but a rapid decrease from the $1 \mathrm{~m}$ layer downward to the $1.5 \mathrm{~m}$ layer registered only $29 \%$. At the bottom layer, it was so little in content that it was barely detectable. With the passage of time, it decreased more and more till its minimum is reached at 6:00 in the following morning. Owing to its downward dispersion, however, the $1.5 \mathrm{~m}$ layer showed a tendency towards its gradual increase. After 8:00, it began to increase again, the assimilation in the pond becoming active.

In this pond only 2 meters deep, the surface layer rich in phytoplankton became: excessively saturated with $\mathrm{O}_{?}$ in the daytime, and although this saturation became gradually reduced at night, less than $140 \%$ was never registered. Therefore, the state of $\mathrm{O}_{2}$ over-saturation was kept up all day and all night. From the $1.5 \mathrm{~m}$ layer downward, however, the saturation point of $\mathrm{O}_{2}$ could never be reached, and there was little or no dissolved $\mathrm{O}_{2}$ at the $2 \mathrm{~m}$ bottom layer.

\section{b) Pond No. 202 at Kôyôen}

This pond which was constructed by damming up a valley on the side of a granitic mountain mass has a depth of water $3.7 \mathrm{~m}$. The bottom deposit-a thin layer of grey mud, with granite exposed only a little. The water colour is bluish green, somewhat cloudy, looking whitish. The pond was of an oligotrophic type, having scanty phytoplankton.

Water temperature: The water temperature at the surface layer showed $27.5^{\circ}$ $\mathrm{C}$ in its maximum and $25.3^{\circ} \mathrm{C}$ in its minimum, the difference being $2.3^{\circ} \mathrm{C}$. At 
the bottom layer, $22.3^{\circ} \mathrm{C}$ was registered at its maximum and $20.1^{\circ} \mathrm{C}$ at its minimum, with the same difference of $2.2^{\circ} \mathrm{C}$ in both cases, as compared with the surface layer. Although somewhat whitish, the water was pretty clear, with a transparency of $2.5 \mathrm{~m}$ against the depth of $3.7 \mathrm{~m}$. The water temperature was found approximately homothermal as far down as 2 meters, from where downward a decrease around $20^{\circ} \mathrm{C}$ was registered. The diurnal fluctuations of temperature were not so great, but from 4:00 till 6:00 in the morning it was at its minimum.

pH : Slightly acid; this pond showed the $\mathrm{pH}$ values $6.4 \sim 6.5$ at the surface layer and 6.0 6.1 at the bottom layer, and never become alkaline all day and all night. The vertical distribution of $\mathrm{pH}$ value was found to be linear, having little diurnal fluctuations.

Dissolved $\mathbf{O}_{2}$ : The maximum content of dissolved $\mathrm{O}_{2}$ was $5.62 \mathrm{cc} / \mathrm{l}$, and $99.1 \%$ saturation at the surface layer at 14:00, the layer different from this the value being less than the above. At the 0 2 $\mathrm{m}$ layer, around $90 \%$ was detectable. At the $3 \sim 3.5 \mathrm{~m}$ bottom layer, the values somewhat decreased but $30 \sim 50 \% \quad \mathrm{O}_{2}$ saturation was still detectable. Little change was observed in the vertical distribution of $\mathrm{O}_{2}$, and the $\mathrm{O}_{2}$ content never exceeded its saturation point all day and all night. Owing to the presence of $\mathrm{O}_{2}$ dissolved even at the deepest bottom layer, the pond is to represent an oligotrophic type.

\section{c) Shimo-ike Pond on Itami Tableland}

This is a pond formed in an eroded valley on the diluvial tableland. 4 meters in depth: the pond fairly abounded in planktonic organisms. The pond was moderately contaminated. An association of Hydrilla verticillatc was found at the bottom which was covered with dark-coloured mud.

Water temperature: The temperature ranged from $27.1^{\circ} \mathrm{C}$ to $28.5^{\circ} \mathrm{C}$ at the surface layer and from $18.7^{\circ} \mathrm{C}$ to $20.3^{\circ} \mathrm{C}$ at the bottom layer. In the latter, the temperature was unexpectedly low. As compared with the other two ponds described already, the difference of temperatures between the surface and the bottom layers was the greatest. The vertical distribution ranged between 26.6 $28.5^{\circ} \mathrm{C}$ as far down as $0 \sim 2 \mathrm{~m}$, and $24 \sim 25^{\circ} \mathrm{C}$ at the $3 \mathrm{~m}$ layer, showing at the $4 \mathrm{~m}$ layer an abrupt lowering, $19.0^{\circ} \mathrm{C}$ or so.

pH : In the daytime the surface layer showed $\mathrm{pH}$ value 8.5 or more, which began to go down at midnight till it reached 7.3 in the early morning. The $2 \mathrm{~m}$ layer maintained a neutral value of $\mathrm{pH} 7.0$ and the $3 \mathrm{~m}$ layer slightly acid, 6.4 $\sim 6.5$.

Dissolved $\mathrm{O}_{2}$ : Shimo-ike pond held its $\mathrm{O}_{2}$ content between the afore-mentioned two ponds. At the $0 \sim 1.5 \mathrm{~m}$ layer the saturation was barely detectable. Although was cloudy in the morning, the $\mathrm{O}_{2}$ content showed $124 \%$ saturation at the surface layer and $107.3 \%$ at the $1 \mathrm{~m}$ layer, and after sunset, it remarkably increased at 20:00. It began later, to go down and at 4:00 before sunrise, the surface layer showed $114.2 \%$ and the $1 \mathrm{~m}$ layer $112.2 \%$. At 6:00 the surface layer came down 
to $112.0 \%$ and the $1 \mathrm{~m}$ layer down to $110.3 \%$, showing an approximation to the saturation point. From 8:00 onward, the value began to increase again. The state of over-saturation was invariably observed at the $0 \sim 1.5 \mathrm{~m}$ layer, and from $2 \mathrm{~m}$ layer downward, non-saturation was always detectable. At the $3 \mathrm{~m}$ layer, $\mathrm{O}_{2}$ was almost non-existent. This pond only $4 \mathrm{~m}$ in depth was found to have a layer $(3 \sim 4 \mathrm{~m})$ with no $\mathrm{O}_{2}$ dissolved in the water all day and all night.

From what have been described above it is possible to know some characters of a pond as compared with a lake. First, the changes of water temperature are greater in a pond 2 4 meters deep than in a lake. Second, even the temperature at the bottom layer undergoes some changes. Third, both the nutritional condition and the generation of phytoplankton organisms have much to do with the fluctuations of both dissolved $\mathrm{O}_{2}$ content and $\mathrm{pH}$ value. Besides these, it must also be pointed out that the condition of mud at the bottom and the growth of plants prove to be the distinctive characters of a pond.

\section{PLANKTON COMMUNITIES AND THEIR VERTICAL AND DIURNAL FLUCTUATIONS}

The important plankton organisms in Shimo-ike pond at Itami are as follows:

Zooplankton organisms: Eodiaptomus japonicus, Cyclops vicinus, Eodiaptomus nauplius, Cyclops nauplius, Bosmina longirostris, Dicphanosoma brachyurum, Asplanchna priodonta, Polyarthra trigla and Centropyxis aculeatc. Mixed with them are found Bosminopsis deitersi, Conochilus unicornis, Pedalia mira, Filinia longiseta, Schizoserca diversicornis, Keratella cochlearis, Tetramastix opoliensis, although they occur scantily.

Phytoplankton organisms : Ceratium hirundinella, Oscillatoria sp. (appearing in abundance). Besides these, Melosira italica, Volvox aureus, Microcystis aeruginosa are found, though scantily. Furthermore, there live the larvae of a phantom gnat Chaoborus albipes. With regard to those species whose individuals were found rather in abundance, their diurnal fluctuations are shown (Fig. 14) as the number of individuals of each species found in $1 l$ of water.

Zooplankton organisms have a tendency not to have a diffuse distribution but to form aggregations in fixed places, so that it is difficult to show their movements numerically. The investigation, however, made it possible to obtain the following findings. The Individuals of both Eodiaptomus and Cyclops of Copepoda and their nauplii could be collected in greater numbers at night than in the daytime; it seemed to indicate that they would come up to the surface at night. Eodiaptomus and Cyclops had their main biozones at different layers, the former coming together at the $0 \sim 1 \mathrm{~m}$ layer and the latter at the $2 \sim 3 \mathrm{~m}$ layer. In the daytime Bosmina and Diaphanosoma both belonging to Cladocera were found more abundantly at the $1 \sim 2 \mathrm{~m}$ layer than the $0 \sim 1 \mathrm{~m}$ layer, and after nightfall they came up to the surface. Centropyxis of Protozoa showed the same tendency. Little could be known definitely about the movements of Astanchna and Polyarthra 

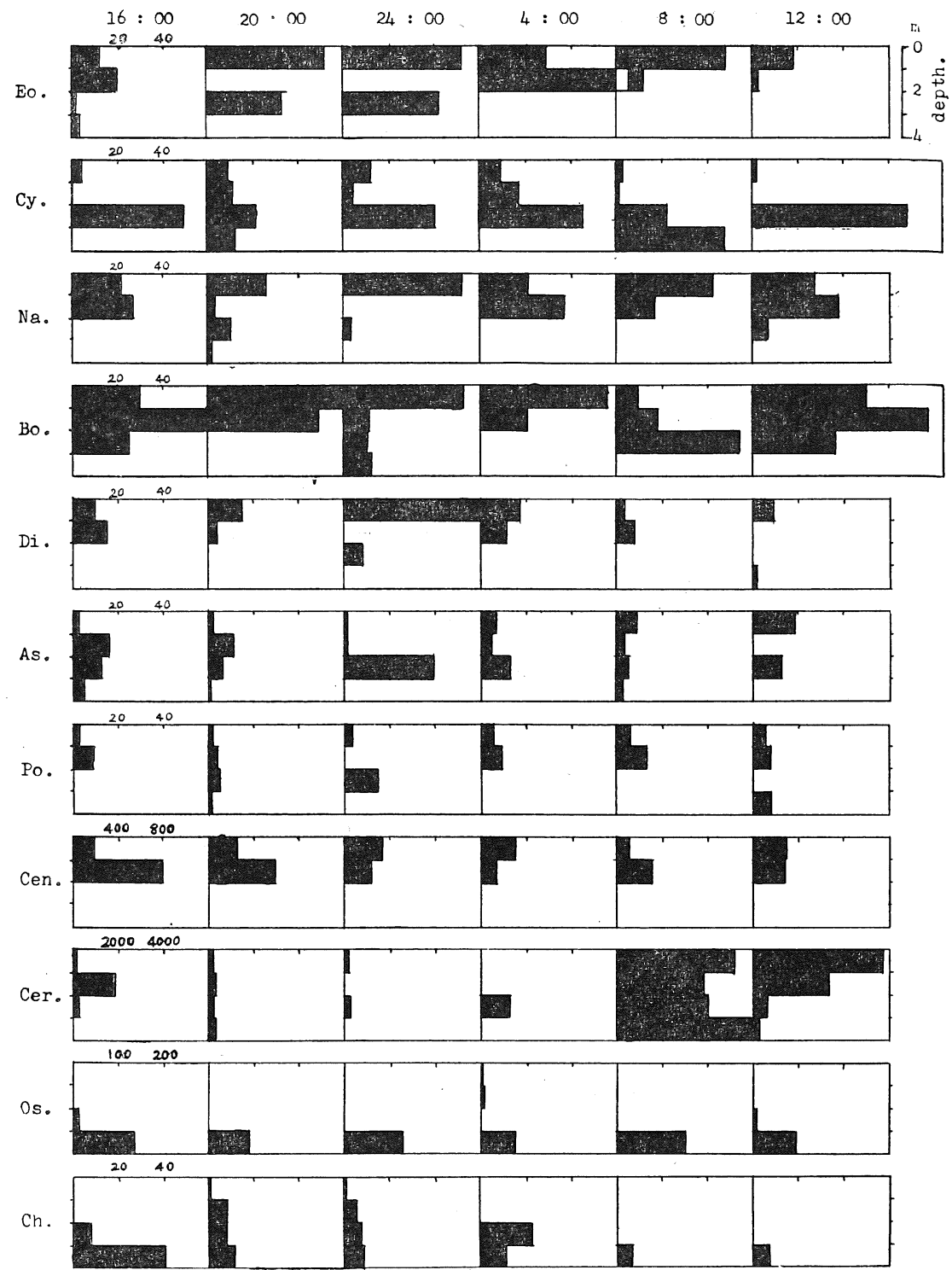

Fig. 14. The vertical and diurnal migration of plankton in Shimo-ike pond at Itami City.

Eo. : Eodiaptomus japonicus, Cy. : Cyclops vicinus,

Na. : Nauplii, Bo.: Bosmina longirostris,

Di. : Diaphanosoma brachyurum, As.: Asplachna priodontc,

Po. : Polyarthra trigla, Ce. : Centropyxis sp.

Cer.: Ceratium hirundinella, Os.: Oscillatoria sp.

Ch. : Chaojorus albipes. 
both belonging to Rotifera, but they seemed to cloud about the surface layer in the daytime and at the middle layer at night. Ceratium hirundinella, instead of its diurnal positional shifts, showed a phenomenon called 'water change' among pisciculturists. By the middle of the night, individuals of Ceratium were not so plentiful, but at 8:00 in the next morning, the colour of water began to change, showing a brownish green colour probably due to its abrupt extraordinary multiplication. Oscillatoria seldom appeared at the surface layer, setting at the 3 4 $\mathrm{m}$ layer all the time. Chaoborus larva is well known for its positional shifts both in the daytime and at night. In the daytime individuals of Chaoborus lay hidden at the bottom mud of the pond where there has hardly any $\mathrm{O}_{2}$. They were clearly observed to come up to the surface layer at sunset, to go down again to the deeper layers at daybreak and conceal themselves at the bottom.

Most of the plankton organisms in pond No. 202 at Kôyôen consisted of animals whose movements in the pond were nearly the same as the foregoing description, but they were found in the bottom layer due to the existence of the dissolved $\mathrm{O}_{2}$. The pond at Chausuyama was occupied chiefly by phytoplankton such as Microcystis, Anabaena, Scenedesmus, Acanthosphaera, Stephanodiscus and Melosira. The number of individuals are remarkably abundant forming "water-bloom". Little or no notice was taken of their positional shifts or movements.

\section{THE SEASONAL FLUCTUATIONS OF PHYSICAL AND CHEMICAL CONDITIONS AND PLANKTON COMMUNITIES}

In 1952 the writer published a report on the seasonal changes of chemical conditions and plankton communities observed for one year in ponds No. 1 and No. 8 lying in the northern part of Osaka. Later he summarized long-term and more detailed studies in this connection. In one case, measurements and collections were conducted 1 3 times monthly in Shimo-ike pond at Itami for four years from October, 1954 till September, 1958. In another observations of quantitative fluctuations of plankton were carried on $1 \sim 3$ times monthly in Tsujiga-ike pond, Ikeda City for three years from Feburary, 1957 till January, 1960.

\section{THE FLUCTUATIONS OF THE PHYSICAL AND CHEMICAL CONDITIONS IN SHIMO-IKE POND AT ITAMI}

Water temperature: The minimum temperature of $5 \sim 6^{\circ} \mathrm{C}$ on the surface and that of $4.7 \sim 6.0^{\circ} \mathrm{C}$ at the bottom were registered in January every year, the pond never freezing over. The maximum temperature on the surface was $32.5^{\circ} \mathrm{C}$ in July, $1955,34.0^{\circ} \mathrm{C}$ in August, $1956,30.8^{\circ} \mathrm{C}$ in August, 1957 and $32.5^{\circ} \mathrm{C}$ in July, 1958. As compared with the bottom, the surface could easily be affected by daily 
132

陸水学 雑誌

[Vol. 22

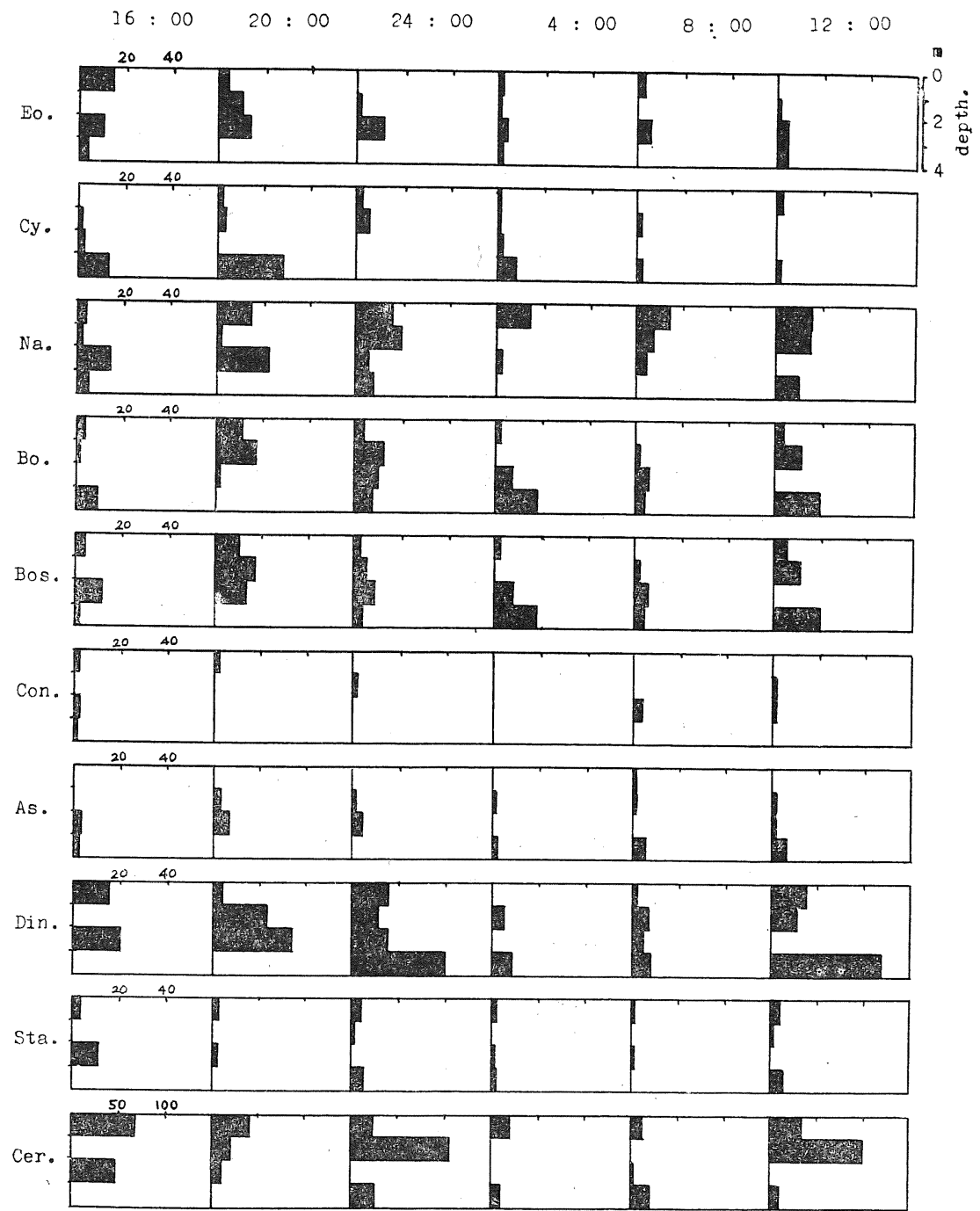

Fig. 15. The vertical and diurnal migration of plankton in pond No. 202 at Kôyoen

Eo. : Eodiaptomus japonicus, Cy.: Cyclops vicinus,

Na.: Nauplii, Bo. : Bosmina longirostris,

Bos. : Bosminopsis deitersi, Con.: Conochilus unicornis,

As. : Asplanchna priodonta, Din. : Dinobryon divergens,

Sta. : Staurastrum paradoxum, Cer. : Ceratium hirundinlla 

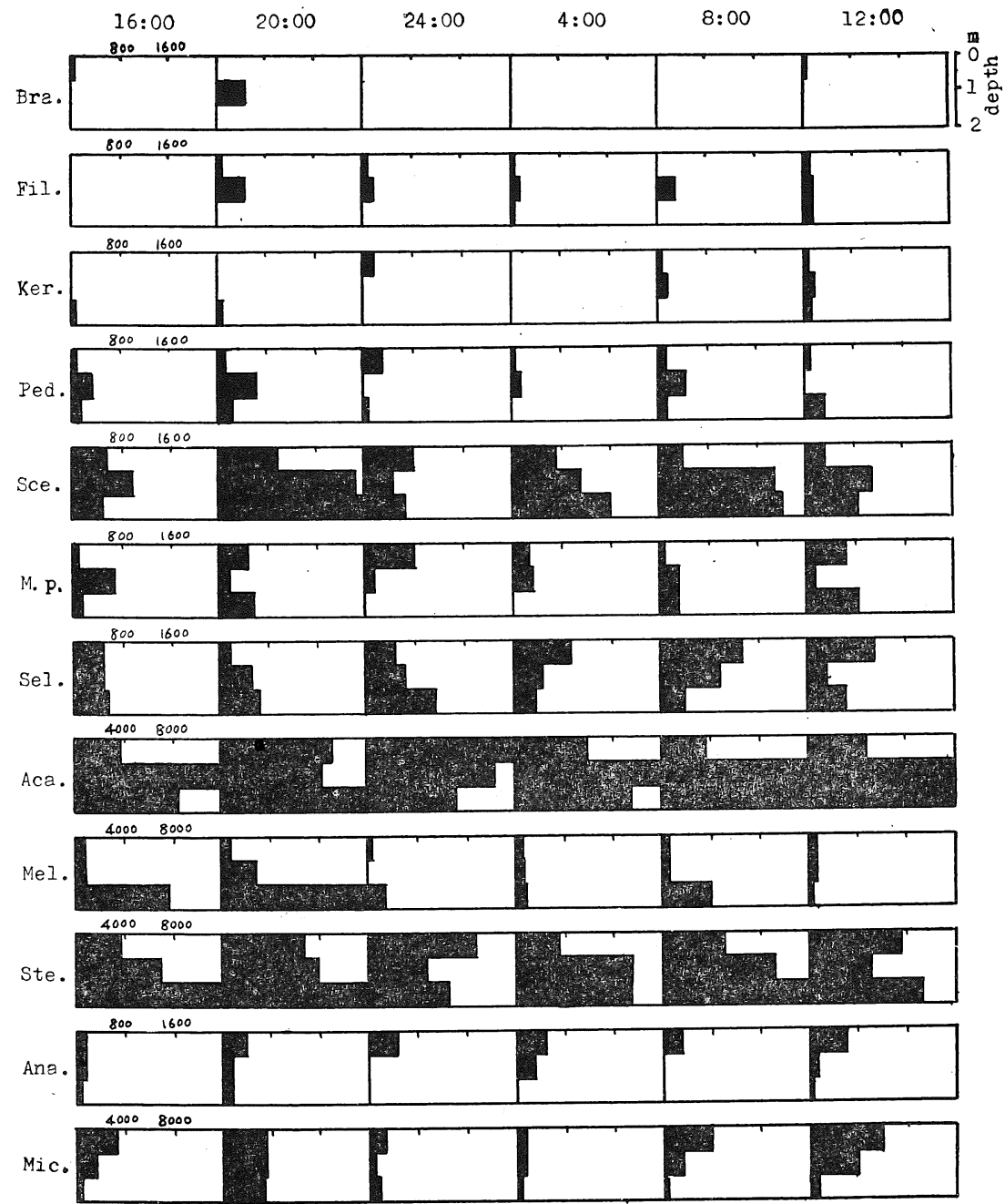

Fig. 16. The vertical and diurnal migration of plankton in Chausuyamaike pond at Tennoji in Osaka City.

Bra. : Brachionus calyciflorus, Fil.: Filinia longiseta,

Ker.: Keratella cochleris, Ped.: Pediastrum duplex,

Sce.: Scenedesmus spp., M.P.: Micractinium pusillum,

Sel.: Selenastrum sp., Aca.: Acanthosphaera sp.

Mel.: Melosira granulata, Ste.: Stephanodiscus sp.,

Ana.: Anabaena flos-aquae, Mic.: Microcystis aeruginosa 
weather with regard to its temperature, but little difference in temperature was shown between the succeeding months. No thermocline (metalimnion) in summer was seen as could be observed in a lake.

In a period during the spring and summer of 1956, a great difference in temperature was observable between the surface and the bottom, probably due to the thick growth of Hydrilla verticillata on the bottom this year. It floated up to the surface after a heavy rain at the beginning of June and covered almost half the surface of the pond. It remained till the latter part of July; died and decayed into fragments in mid-August. It produced some effects on the $\mathrm{pH}$ value, transparency and organic matter of the pond.

The depth of water of this pond was usually a little over 3 meters, but decreased to 2.2 2.5 meters in the summer of 1955 and in the winter of both 1957 and 1958. The vertical distribution as well as annual fluctuations of its water temperature are shown in Figs. 17 and 18.

Because the pond was not deep enough, heat reached down even to the very bottom, so that the difference in temperature was very slight between the surface and the bottom. Even in winter the water temperature seldom fell below $5^{\circ} \mathrm{C}$ and it never remained unchanged. There was a good circulation of water all the year round, and the pond seemed to maintain nearly the same condition throughout.

pH value : The $\mathrm{pH}$ value usually showed neutrality, turning a little alkaline in summer and slightly acid in winter. But the pond showed an unusual state in 1956, the water becoming remarkably alkaline at the surface layer in May with

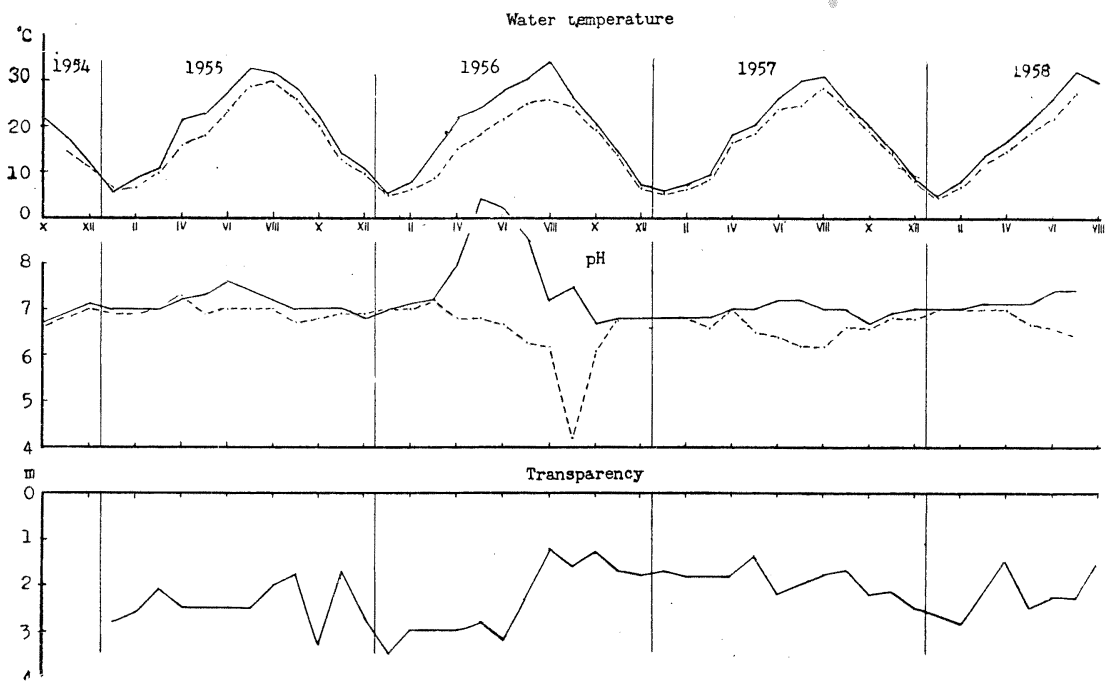

Fig. 17. The seasonal changes of the water temperature, the $\mathrm{pH}$ and the transparency in Shimo-ike pond at $t$ imi City. 

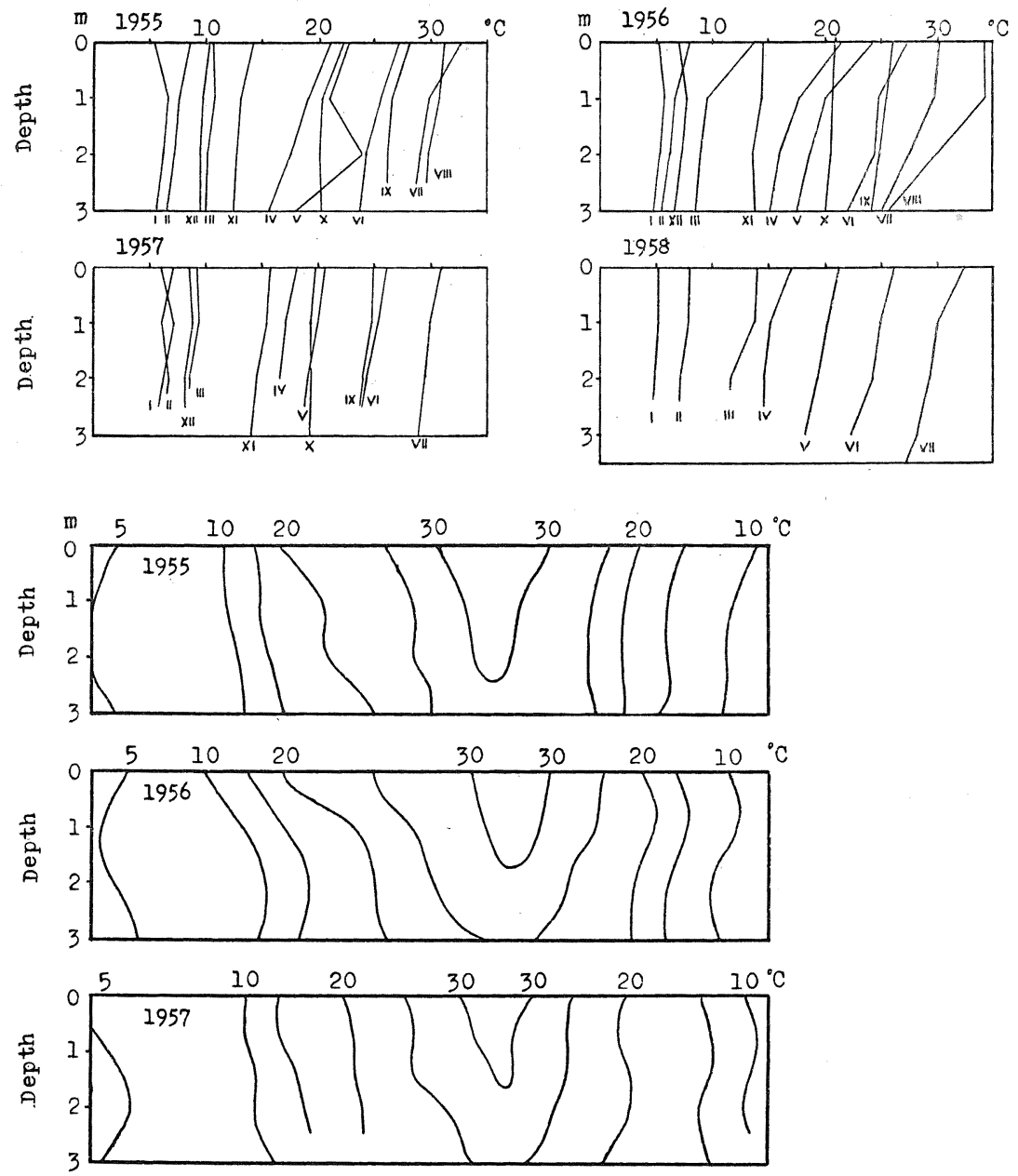

Fig. 18. The vertical distribution and the seasonal change of the water temperature in Shimo-ike pond at Itami City.

its maximum $\mathrm{pH}$ value 9.4. At the bottom layer the $\mathrm{pH}$ value went down to 4.2 after August and September, when the rotten fragments of Hydrilla verticillata precipitated to the bottom, showing slight acidity till the former neutrality was restored the next year (Figs. 17 and 19).

Transparency : In January, 1955, the transparency of this pond was 2.8 meters. 
After once decreased to 2 meters in March, it increased to 2.5 meters again in April and thereafter, probably due to the change in quality and quantity of plankton. In the first half of 1956 the water was very clear having a great transparency, which was however considerably reduced with the decomposition of the fragments of Hydrilla verticillata, its ill effect remaining even in the first half of the year after. The normality was restored in the autumn of 1957 (See Fig. 17).

Dissolved $\mathrm{O}_{2}$ : It is regretted that no measurement of the vertical distribution of $\mathrm{O}_{2}$ was made in 1956 when the afore-said unusual state occurred in the pond, but the data obtained during the two years 1957 and 1958 will be enough to suggest the yearly vertical changes (See Fig. 20).

The dissolved $\mathrm{O}_{2}$ content was $8.8 \sim 9 \mathrm{cc} / l$ in January; no difference in its content was seen from the surface layer down to the bottom layer, but after that time, month after month, the content of $\mathrm{O}_{2}$ became less especially at the bottom layer. In July, 1957, however, at the 1 meter layer there was a remarkable increase of $\mathrm{O}_{2}$ which showed a further increase after September. The decrease at the bottom layer seemed to be due to the oxidation of organic matter contained in the bottom mud.

The $\mathrm{O}_{2}$ content was generally in an over-saturation of $100 \sim 120 \%$ as far down as the 2 meters layer, but it was deficient at the $2.5 \sim 3 \mathrm{~m}$ layer, almost nonexistent in summer. The over-saturation as much as $200 \%$ at the $1 \sim 2 \mathrm{~m}$ layer in summer was due to the assimilation of abundant planktonic algae.

$\mathrm{KMnO}_{4}$ Consumption: This reached its peak of $13.0 \mathrm{mg} / l$ in March, 1955, remaining almost constant $5 \sim 8 \mathrm{mg} / l$ thereafter; rose again during the intervening period between January and February, 1956, and fell suddenly in March. In
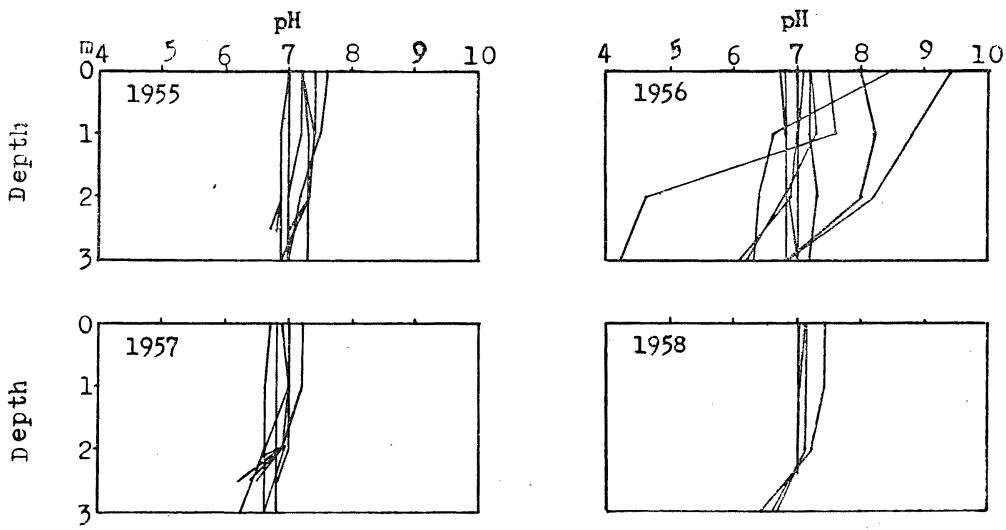

Fig. 19. The vertical distribution and the seasonal change of $\mathrm{pH}$ in Shimo-ike pond at Itami City. 

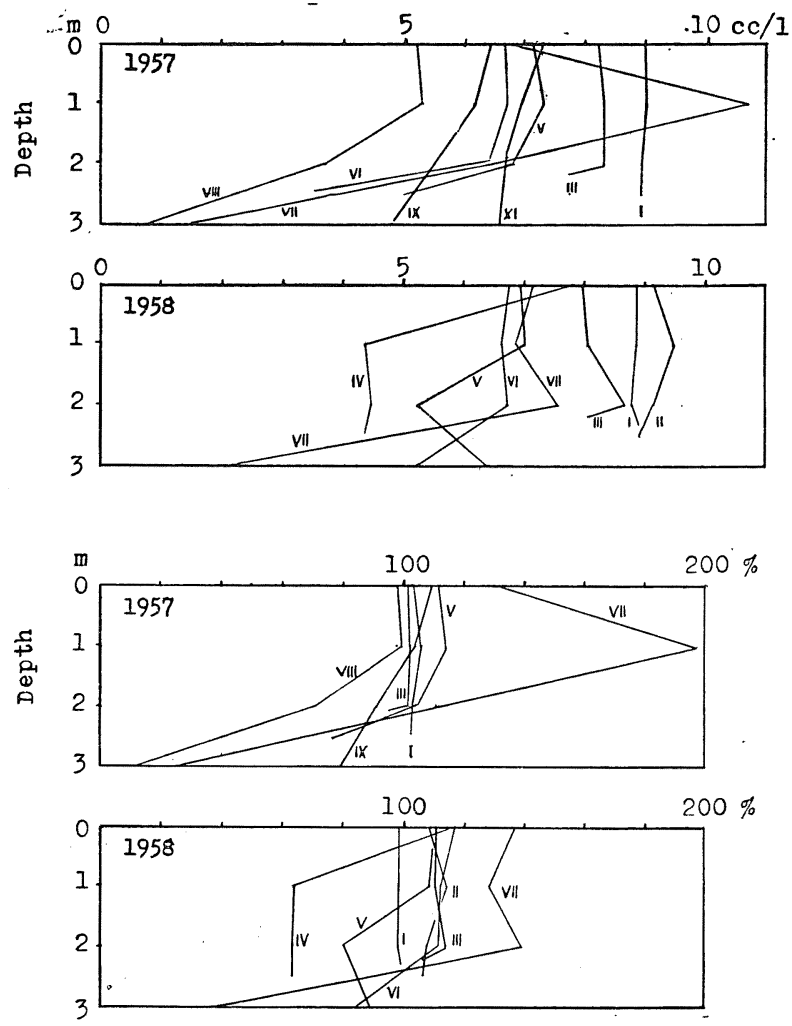

Fig. 20. The vertical distribution and the seasonal change of dissolved oxygen in Shimo-ike pond at Itami City.

succession to it, the afore-said floating up of Hydrilla verticillata from the bottom brought about an exceptional rise in $\mathrm{KMnO}_{4}$ consumption, the maximum becoming $20 \mathrm{mg} / \mathrm{l}$. This abnormal condition continued till the end of 1957, and despite its gradual lowering, the consumption rate was still greater, as compared with that of 1955. It is not perhaps so until March, 1958, when its decreased consumption of $5 \mathrm{mg} / l$ was recorded and normality was restored.

Cl-ion: $\mathrm{Cl}^{-}$content remained neary equal, though there were some slight changes. As compared with other ions, it could be said to have a greater stability, probably because it has nothing to do with any metabolic production and consumption. Even in 1956 when an exceptional phenomenon occurred in resulting from the luxuriant growth of Hydrilla verticillata, it showed no particular change and decreased to $10.0 \mathrm{mg} / l$ after October. 
The fact that so long as there was no particular environmental change and $\mathrm{Cl}^{-}$ content remained almost the same were likewise noticed with regard to ponds Nos. 1 and 8 in the northern part of Osaka, when the writer investigated them in 1952.

$\mathrm{SO}_{4}$-ion : No remarkable change in $\mathrm{SO}_{4}=$ was recorded in 1955, but in 1956 a rapid increase occurred over a period of three months from June to September. Thereafter, there were fluctuations in its content several times; on the whole, it seemed that there was more $\mathrm{SO}_{4}=$ during this period than in 1955 .

Ca-ion : $\mathrm{Ca}^{++}$content has periodic fluctuations every year. In 1956, when an exceptional change occurred by the extraordinary growth of Hydrilla verticillata, the fluctuations of $\mathrm{Ca}^{++}$seemed to be somewhat parallel with the changes in $\mathrm{KMnO}_{4}$ consumption. It may however be said that this had nothing to do with the growth and decay of Hydrilla verticillata, because the maximum and minimum of $\mathrm{Ca}^{++}$content remained the same as that in the preceding years.
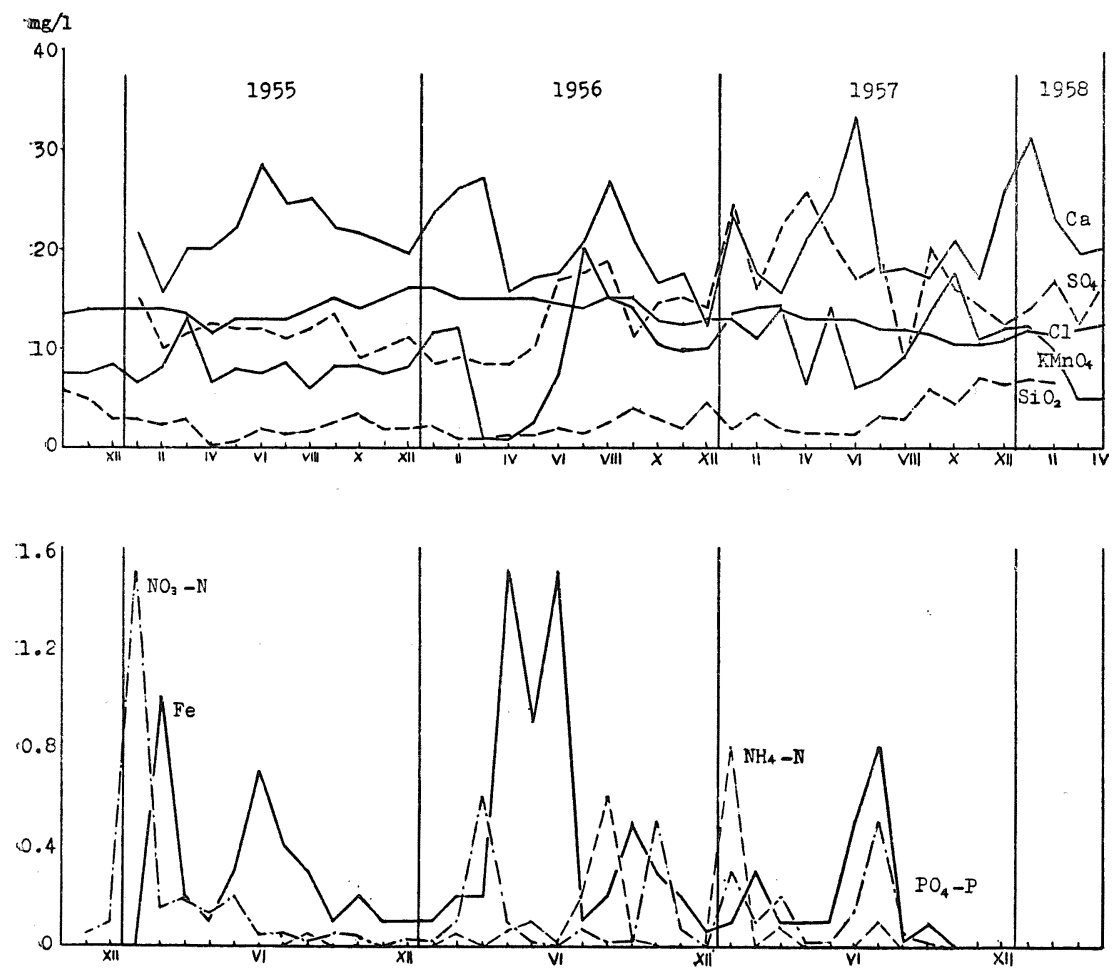

Fig. 21. The seasonal change of the dissolved substances in Shimo-ike pond at Itami City. 
$\mathrm{SiO}_{2}$ : It is a well-known fact that $\mathrm{SiO}_{2}$ content is related to the existence or non-existence of diatoms. On the whole, there was little dissolved $\mathrm{SiO}_{2}$, and every year it had a tendency to increase from autumn through early spring and to decrease from March to May. From the second half of 1957 through 1958, it showed an increase over the preceding years.

Fe-ion: When $\mathrm{O}_{2}$ is dissolved in plenty and the $\mathrm{pH}$ value is neutral or alkaline, Fe-ion is said to precipitate as insoluble oxides or hydroxides. The $\mathrm{pH}$ value of this pond almost invariably remained neutral or alkaline except when it was found to be remarkably acid at the bottom layer during the three months from August to October, 1956. It was presumed that $\mathrm{Fe}^{++}$at the surface layer could never be more than $1 \mathrm{mg} / l$, but actually more than $1 \mathrm{mg} / l$ was observable or twice a year. It may be said that clay and humus in water served $\mathrm{Fe}^{++}$as forming its protective colloid. The Fe-ion content showing its peak in summer may also be explained by assuming that the oxides or hydroxides of $\mathrm{Fe}^{++}$contained in the bottom mud may have dissolved into the water as $\mathrm{Fe}^{++}$and thus diffused to the upper layer, because of $\mathrm{O}_{2}$ shortage at the bottom layer in summer.

Nutritive salts : $\mathrm{PO}_{4} \equiv$ was very scanty. Very often it was not detectable at all. There was present more of it from autumn through winter $(0.02 \sim 0.05 \mathrm{mg} / \mathrm{l})$ and in summer.

There were more $\mathrm{NH}_{4}{ }^{+}$and $\mathrm{NO}_{3}{ }^{-}$than $\mathrm{PO}_{4} \equiv$, their seasonal fluctuations being greater. In 1956, $\mathrm{NH}_{4}{ }^{+}$increased after the decomposition of Hydrilla verticillata. A considerable increase of $\mathrm{NO}_{3}{ }^{-}$was found in January, 1955, in March, 1956 and in July, 1957. In the former two cases, the increase could be recognized as a general tendency, but the cause for its increase during the summer of 1957 was beyond comprehension.

It may be considered that all these findings show the characteristics of a pond whose volume of water is not plentiful.

\section{THE SEASONAL FLUCTUATIONS OF PLANKTON COM- MUNITIES}

From October, 1954 through August, 1958, plankton was collected in the central part of Shimo-ike pond at Itami by using a row-boat. It was no quantitative collection, so that the results of the microscopic examination were denoted by the frequency of individual detection of each species into the following five classes, namely, $\mathrm{rr}, \mathrm{r},+, \mathrm{c}$ and $\mathrm{cc}$. The important species detected are listed below:

Cladocera:

Bosmina longirostris

Bosminopsis deitersi

Chydorus sphaericus

Diaphanosoma brachyurum

Coperoda :

Cyclops vicinus

Eodiaptomus japonicus

Mesocyclops leuckarti

\section{ROTIFERA :}

Asplanchna priodonta

Keratella cochlearis

Brachionus calycifiorus

$B$. falcatus

$B$. angularis

Schizocerca diversicornis

Filinia longiseta

Conochilus unicornis 
Protozoa :

Ceratium hirundinella

Volvox aureus

Eudorina elegans

Dinobryon divergens

Chlorophyta :

Pediastrum duplex

Staurastrum sp.

Mougeotia sp.

Spirogyra sp.
BACILLARIOPHYTA :

Melosira italica

Synedra ulna

Myхорнута :

Chroococcus sp.

Microcystis aeruginosa

Besides the above, the yearly occurrence of a great number of a hydromedusa Craspedacusta soverbii after its first discovery in the fall of 1952 is particularly noteworthy. The term of its occurrence was usually three or four weeks between July and September, but there was some time-lag from year to year.

The seasonal fluctuations of plankton communities were examined by dividing a year into the following four periods: hiemal, vernal, estival, and autumnal (ShACKLEFJRD, 1929). To these four is sometimes added the prevernal period and further the serotinal period. The workers in this field disagree in their views with this matter of seasonal divisions ; moreover, the terms of planktonic occurrence are so variable from year to year that it is not seldom very hard to say anything definite about the period of occurrence of each planktonic species.

In European and American limnological studies the hiemal (or hibernal) period is usually understood to include the freezing season, but it nor infrequently happens that even autumnal species survive the hiemal season and occur both in spring and in autumn. For instance, EDDY (1934) indicated in his studies of Lake Decature and Park Pond in Illinois Filinia longiseta as an estival species, but the same organism in Shimo-ike pond at Itami investigated by the present writer is regarded to be either a hiemal or prevernal species.

Having considered both from the climatic condition of the Osaka area as the center and from the fluctuations of plankton communities, it seems more appropriate to the writer to establish four seasonal divisions - himal (XI, XII, I, II), vernal (III, IV, V, VI), estival (VII, VIII), and autumnal (IX, X). It not infrequently happens, however, that the vernal season had better be divided into two periods, the first half and the second half.

Cladooera: Both Bosmina longirostrs and Bosminossis deitersi are perennial species, but the former has a greater tendency to multiply in the hiemal season than in the estival, having a shorter range of temperature appropriate to it. The latter multiplies in both seasons, vernal and autumnal, and seems to have a wider range in the temperature requirement. Chydorus sphaericus occurs in nearly the same period as Bosminopsis. As compared with the above-mentioned three species, Diaphanosoma brachyurum is more adapted to higher degrees of temperature. Since its maximum occurrence is restricted only to a short time from the latter part of August through September, it should be referred to the autumnal species, though it also occurs in July. 
COPEPODA : Both Cyclops vicinus and Eodiaptomus japonicus are the predominants of this pond, Mesocyclops leuckarti occurring only scantily. Although both are perennial species, Cyclops shows its maximum multiplication in the hiemal season and Eodiaptomus in the intervening period from the vernal to the autumnal season. From monthly observations it is clear that they occur one after another. Cyclops vicinus occurs abundantly in the hiemal season even in ponds Nos. 1 and 2 of Osaka pref. where there are found no Eodiaptomus; it is probably a good proof that there is a difference between the two in regard to their temperature requirement.

Rotifera : Asplanchna priodonta and Keratella cochlearis multiply in summer but seem to be perennial species. Brachionus falcatus and Schizocerca diversicornis are estival species, occurring only in July and August. The individual number of Filinia longiseta is very scantily throughout the year. Conochilus unicornis occurs continuously. Although they show no distinctive features in their seasonal fluctuations, they seem to be perennial species, as the writer's observations of them in other ponds suggest.

PROTOzOA : Ceratium hirundinella is collected almost all the year round, though shows the seasonal fluctuations. It also sometimes multiplies in an amazing manner. Volvox and Eudorina seem to be estival species, though Dinobryon had better be considered to be a hiemal species. Dinobryon sometimes occurs in June in a low water temperature pond lying in a mountainous area. The species in such a pond may have preference for a low water temperature.

Chlorophyta: There is a tendency that while Mougeotia multiplies in spring and autumn, Pediastrum duplex, Staurastrum sp. and Spirogyra sp. occur in summer. No adequate consideration is possible, because only very few number of individuals can be collected.

Bacillariophyta: The two species Melosira italica and Synedra ulna occur from the hiemal to the vernal season. Judging from the related data of various sources, they should probably be indicated as perennial species in accordance with EDDy's classification.

Myxophyтa : The dominant species is Microcystis aeruginosa. Although its multiplication is at its maximum from summer to autumn, it never occurs so abundantly as to form 'water-bloom'.

In Shimo-ike pond at Itami, there are many species referable to perennial species, but they are not always found abundantly. The fluctuations mentioned, therefore, may be due to the fact that each species has its own favorite range of water temperature and that there exist some inter-specific relations. This pond temporarily subsided by about half a meter at times, but it never dried up. During the three years of observation, the plankton community showed little or no change, repeating nearly the same cycle year by year. So long as there is no great environmental change, stable plankton communites may possibly be maintained for fairly a long period.

The writer pointed out the effect of decomposition of Hydrilla verticillata upon 
(Species )

Bosmina longirostris Bosminopsis deitersi Chydorus spheericus Diaphanosoma brachyrum Cyclops vicinus Eodiaptomus japonicus Asplanchns priodonta Keratelia cochlearis Brachionus falcatus

B. calyciflorus

B. Engularis Schizocerca diversicornis Filinia longiseta Conochilus unicornis Arcella vulgaris Ceratium hirundinella Volvox aureug Eudorina elegans Dinobryon divergens Pediastrum duplex Staurastrum sp. Spirogyra sp. Mougeotia sp. Melosira italica Synedra ulna Chroococcus sp. Microcystis aeruginosa

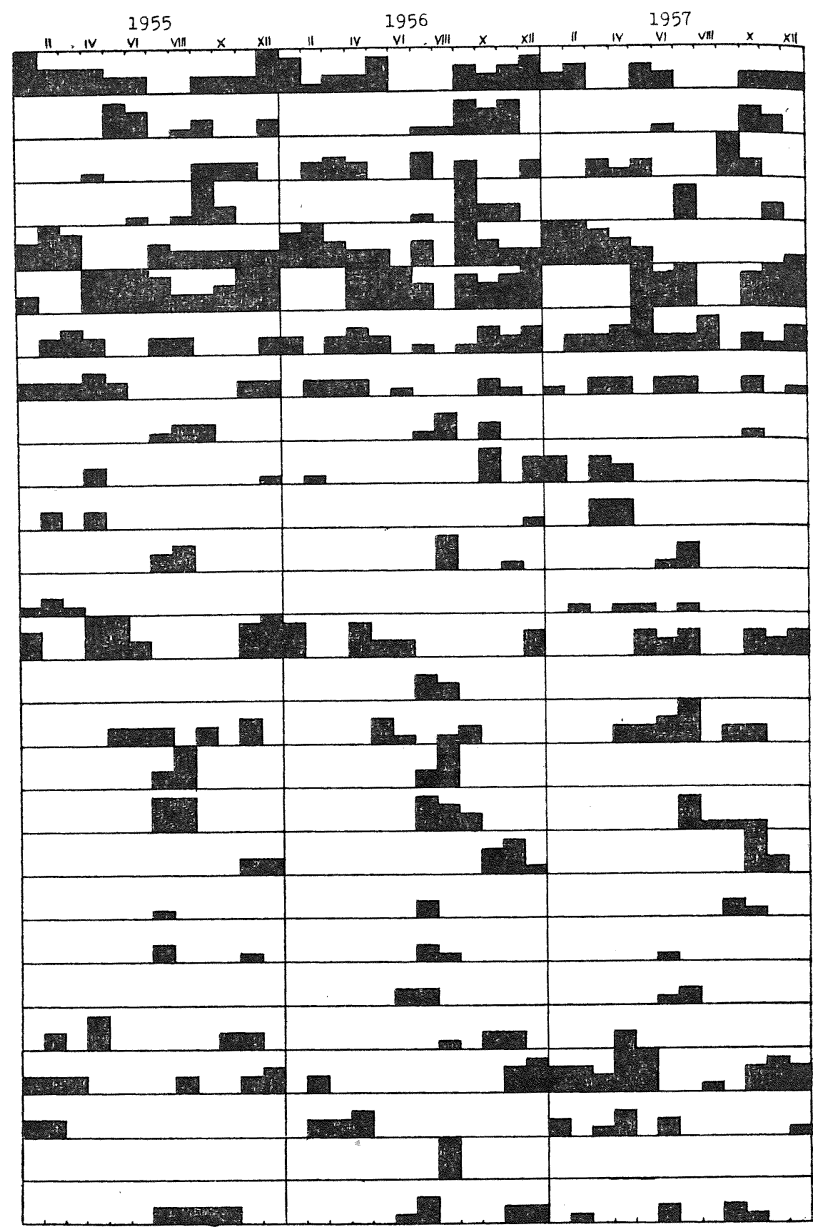

Fig. 22. The seasonal fluctuations of the plankton communities in Shimo-ike pond at Itami City.

the chemical conditions of pond waters. It was of interest how far the change of the chemical conditions in the pond thus produced could affect the plankton organisms in it. As a matter of fact, nearly all the zooplankton organisms disappeared during this period save for Brachionus falcatus and Schizocerca diversicornis. Arcella vulgaris, Chroococcus sp., however, occurred conspicuously during this period alone. It may be said, therefore, that the plankton community was surely affected. However, such plankton communties often occur quite sud- 
denly without any immediate cause or make an abrupt and mysterious disappearance. When this is taken into consideration, there seems to be no definite proof for establishing any inter-relationship between the decomposition of Hydrilla verticillata and the plankton community. Since the plankton community underwent no remarkable change, though the contamination of the pond waters continued till the following year, it might as well be considered that the change of chemical conditions had not much affected the plankton organisms, so long as it remains to this extent.

\section{THE RELATION BETWEEN THE DRYING-UP OF A POND AND ITS PLANKTON COMMUNITY}

a) Field Observations

The writer conducted quantitative collection of plankton in Tsujiga-ike pond at Ikeda, 2 3 times a month from March, 1957 through January, 1960. As compared with Shimo-ike pond at Itami, this pond was more contaminated by the sewage flowing in and both the number of species and individuals of planktonic organisms were more plentiful.

This pond was completely drained off for about four months from December, 1958 to the end of April, 1959 for the purpose of executing the bank protection works. It enabled the writer to obtain useful data to know how far the artificial regulation of water volume or complete draining-off of pond waters, both the phenomena most characteristic of a pond, could affect the plankton community therein. The species of plankton found in the pond are as follows :

[ ] the species which could be found only before the drying-up of the pond.

( ) the species which occurred only after the pond was re-filled with water.

COPEPODA:

Cyclops vicinus

Eodiaptomus japonicus

Cladocera :

Diaphanosoma brachyurum

Daphnia pulex

Bosmina longirostris

Moina macrocopa

Chydorus sphaericus

(Simocephalus vetulus)

ROTIFERA :

[Keratella cochlearis]

K. valga

Polyarthra trigla

Filinia longiseta

Asplanchna priodonta

Brachionus falcatus

$B$. angularis
B. quadridentatus

[B. forficula]

Pompholyx complanata

Conochilus unicornis

Protozos :

Vorticella campanula

[Difflugia corona]

(Eudorina elegans)

[Pandorina morum]

[Volvox aureus]

[Phacus pleuronectes]

Dinobryon divergens

Ceratium hirundinella

[Chlamydomonas sp.]

BacILLARIOPHYTA :

[Melosira italica]

Synedra ulna

Navicula sp. 
[Cymbella tumida]

[Gomphonema sp.]

Chlorophyta :

Spirogyra sp.

Mougeotia sp.

Scenedesmus sp.

\author{
Ankistrodesmus falcatus \\ Staurastrum sp. \\ Oedogonium sp. \\ Mүхорнута : \\ Microcystis aeruginosa
}

The species listed above were very similar to those in Shimo-ike pond at Itami, with regard to the periods of their occurrences. The most conspicuous of all the vernal species was Daphnia pulex. This species is said to be dicyclic, occurring in both seasons, vernal and autumnal, in some places, but in this pond it is monocyclic every year, with its maximum occurrence observed between March and April. As estival species, Brachionus falcatus, Conochilus unicornis, Volvox aureus, Staurastrum sp. and Spirogyra sp. may be mentioned. No notable autumnal and hiemal species were discovered. The rest were mostly perennial species, but as each species had a favorite temperature of its own, there was some time-lag of multiplication between one species and another. This makes it possible to know the inter-specific relationship of plankton by means of quantitative analysis. For instance, Cyclops and Diaptomus are quite different from each other in regard to the maximum of their multiplication and the species belonging to Rotifera abruptly increase immediately after the disappearance of both Daphria and Bosmina. No species of phytoplankton, was detectable in 1957 save for a few species belonging to diatoms, while Pandorina and Chlamydomoras were multiplying. With the disappearance of these two species, Ceratium hirundirella multiplied and taking advantage of the intervening period between the temporary decline of its multiplication and its explosive resurgence, Volvox arrived on the scene. In the year following, when Ceratium, together with Chlamydomoras and Volvox, lost its dominancy, other diatoms and green algae came to alternate. Such phenomena are interesting to note from the viewpoint of balanced state of generations of organisms.

The pond under consideration was drained off for nearly four months from the end of December, 1958 to March, 1959; the exposed bottom mud left hard and dry except the nearly half its whole area where the mud was still damp and wet. Towards the end of May, the pond began to be refilled with water, and when the early summer rain elevated its water level still further, collection of plankton was conducted again. The species of plankton collected were studied in comparison with those known before the draining of the pond. The results obtained are shown in Figs. 23 and 24.

Copepoda, Cladocera and Rotifera, all of which belong to perennial species, were found as abundantly as in the preceding years. Daphnia pulex, a vernal species, appeared but was only short-lived. Among the phytoplankton, Ceratium, Navicula, Spirogyra, Mougeotia, Scenedesmus, Arkistrodesmus, Oedogoruim and Microcystis reappeared. Simocephalus and Eudorina newly appeared, but as many as ten species observed before the drying-up of the pond did not come back after 
(Species)

Cyclops vicinus

Eodiaptomus Japonicus

Nauplius and Copepodid

Diaphanosoma brachyrum

Daphniz pulex

Bosmine longirostris

Moina macrocopa

Chydorus sphaericus

Simocephalus vetulus

Keratella cochlearis

K. valga

Polyerthra trigle

Filinia longiseta

Asplanchna priodonta

Brachionus falcatus

B. angularis

B. quadridentatus

B. forficula

Pompholyx complanata

Conochilus unicornis

Volticella campanula Difflugia corona

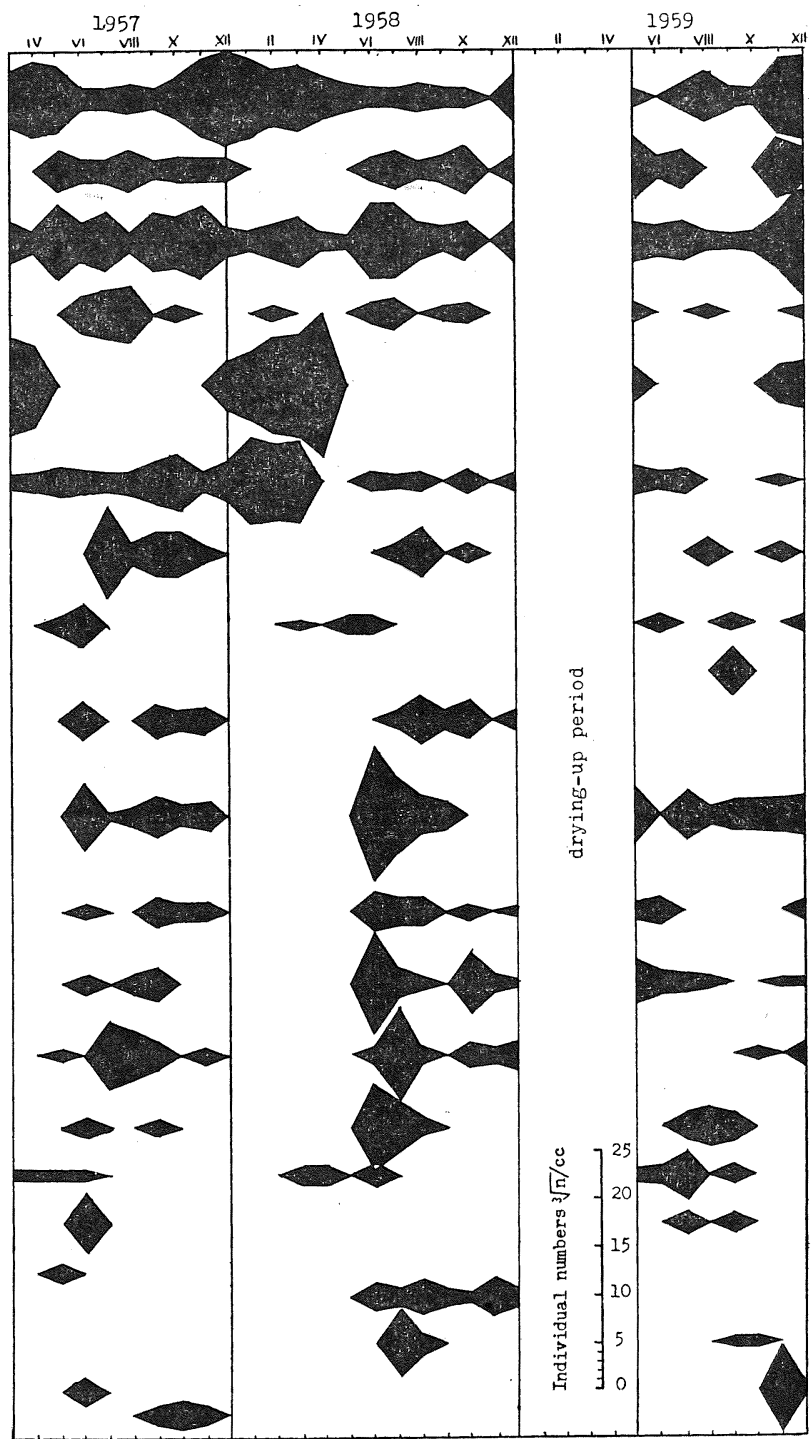

Fig. 23. The seasonal fluctuation of the principal zooplankton in Tsujigaike at Ikeda City and the effects of the drying-up of its water. 


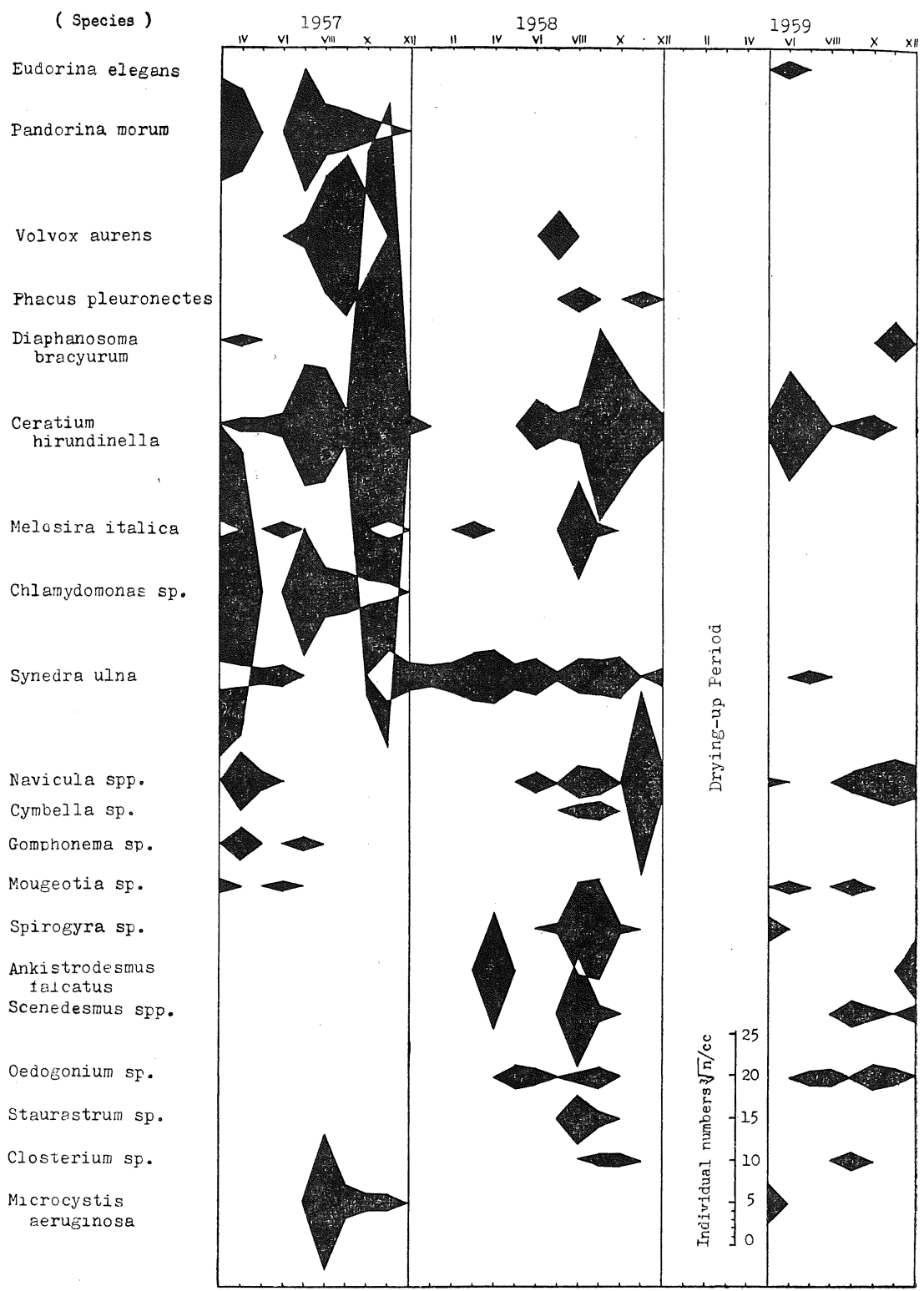

Fig. 24. The seasonal fluctuation of the principal phytoplankton in Tsuigaike pond at Ikeda City and the effects of the drying-up of its water. 
the refilling. This may not mean their complete extinction, but with the decreased number of those peculiar organisms which appeared again, it may be said to have been due to the drying-up of the pond to some extent. It is to be noted, however, that the important members of the plankton community in the pond mostly reappeared. It may possibly be said that drying-up of a pond does not necessarily bring about a complete change of its plankton community.

\section{b) Laboratory Experiments}

i. The artificial incubation of resting eggs of Daphnia pulex

A population of Daphnia pulex collected in Tsujiga-ike pond mentioned above were kept in the laboratory and made to produce ephippia bearing fertilized eggs (if not fertilized, no eggs can be found in the ephippia).

Fifty ephippia (or one hundred eggs) were placed in each glass vessel of 250 $\mathrm{ml}$ capacity and desiccated naturally. They were flooded with water every month, and the rates of incubation were claculated. The resting eggs (winter eggs) were kept in a refrigerator for seven to ten days, and after that, they were taken out

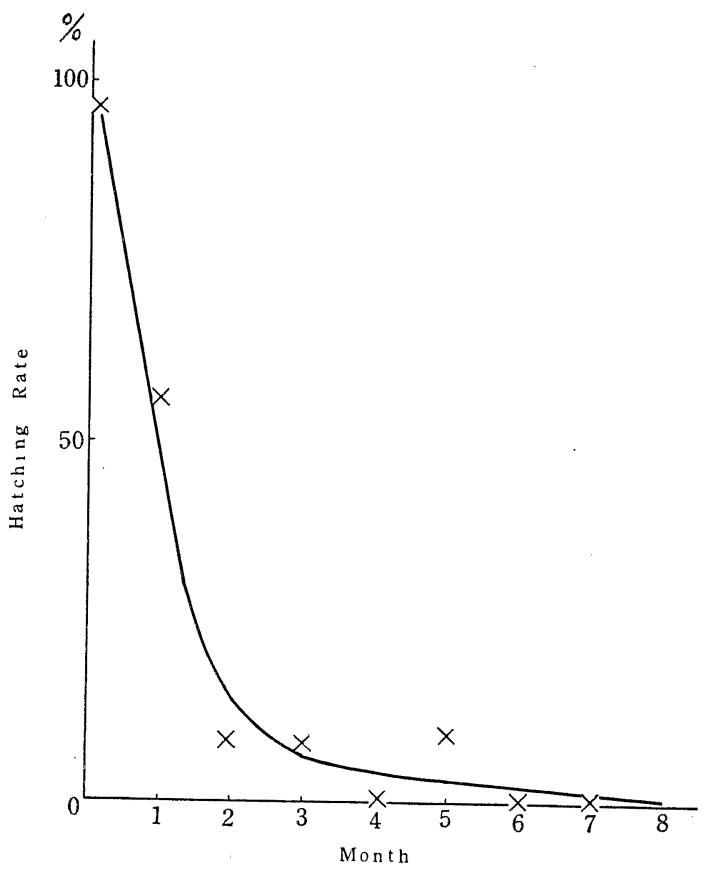

Fig. 25. The relationship between the drying-up periods and the hatching rate of the resting eggs of Daphnia pulex. 
and put back into the water at $15^{\circ} \sim 20^{\circ} \mathrm{C}$. Three to five days after, they began to hatch out. Control experiments (with undesiccated eggs) were made by repeating the same procedure. The results obtained are shown in Fig. 25.

While the control experiment showed a rate of $94.5 \%$ of incubation, the eggs desiccated naturally for one month a decreased rate of $56.1 \%$ and those subjected to two months' natural desiccation a drastically reduced rate of only $8.8 \%$. When eggs desiccated for four months were employed, the incubation rate this time was found to be almost nil.

Resting eggs are generally known to be well adapted to desiccation, but viewed from the experimental results, it is only those desiccated for one month that can have an incubation rate of more than 50\%. Accordingly, their power of adaptation to desiccation is to be less than it has usually been supposed. But just one of them, when successfully hatched, can propagate itself by parthenogenesis, and when this fact is taken into consideration, there may possibly be no need of overestimating the poor adaptive power in the matter of desiccation. Furthermore, when they are preserved in the damp and wet bottom mud as they were in Tsujiga-ike pond, it is highly possible that they will have a much better hatching rate.

ii. Experimsnt with the bottom mud of dried-up Minamimonzen-ike pond

Minamimonzen-ike pond is pond No. 2 lying in the northern part of Osaka prefecture, representing one of eutrophic ponds. The pond was drained off in mid-December, 1959, and, after fish in it were caught, was left dry till mid-May, 1960. The pond was completely emptied of its water, as its southern bank and its waterway had to be repaired. As in Tsujiga-ike pond, the bottom of this pond was composed of thick black mud, leaving nearly two-thirds of the whole area damp and wet. Even six months after the drainage, it was impossible to step in for more than a few meters distant from the bank.

Small blocks of mud $1 \mathrm{~cm}$ thick were scooped off the surface of the bottom mud and placed them in glass vessels (each of about $25 \mathrm{~cm}^{2}$ ). Then distilled water was poured in and plankton organisms revived out of mud were put under observation. The mud blocks were obtained as much as possible from various spots in the central part of the pond. In order to detect the difference due to the degree of desiccation, some samples were desiccated naturally for one week and the other samples for two weeks. The results of observation are shown in Fig. 26.

Owing to the small size of the vessels, the water in them was quite different in its quality from the pond water. It may be said that this was defective for an experimental purpose, but so far as such an experiment was concerned, it couldn't be helped. Among the organisms that could thus be detected, the dominants were polysaprobic ciliates and also those often found living in the foul water or crawling about on the surface of bottom, probably due to gases issued forth 
( Spec1es)

Dipler trigona Rotifera vulgario R. ecutinurus Brachionus angularis

Keratella cochlearis Mytilina ep.

Fulcularia sp.

Asplanchne priodonte

Dephnis fulex

Moine mecrocopa

Cyclops sp.

Eodieptomus jafonicus

Paramoecium caudatum

Greucome pyriformis

Lionotus fasciola

Euplotes charon

Stylonichia sp.

vorticelis campenula

Halteria grandinello

Flexiphylium sp.

Colpidium sp.

Euchelys sp.

(Smeil ciliata)

Difflugia corona

Difflugis sp.

Arcella vulgaris

Trachelomonas ensifera

Euglena acus

Eugiena viridis

Suriliera elegans

Phacus pleuronectes

Pinnuleria viridis

Nevicula cryftocephala

Stauraneis phenicentron

Synedra uins

Nitzechia palea

Melosira granulato

Dipioneis ovelis

Cymatopleure soles

Cymbella turgida

Rhopelodie gibberula

Fragilaria sp.

Gyrosigme ecuminatum

Closterium scerosum

Scenedesmus spp.

Fediastrum simplex

Staurastrum sp.

Oscillatoria limosa

Ankistrodesmus $f a l$ catus

Aphanocapusa sp.

Observation II Observation III

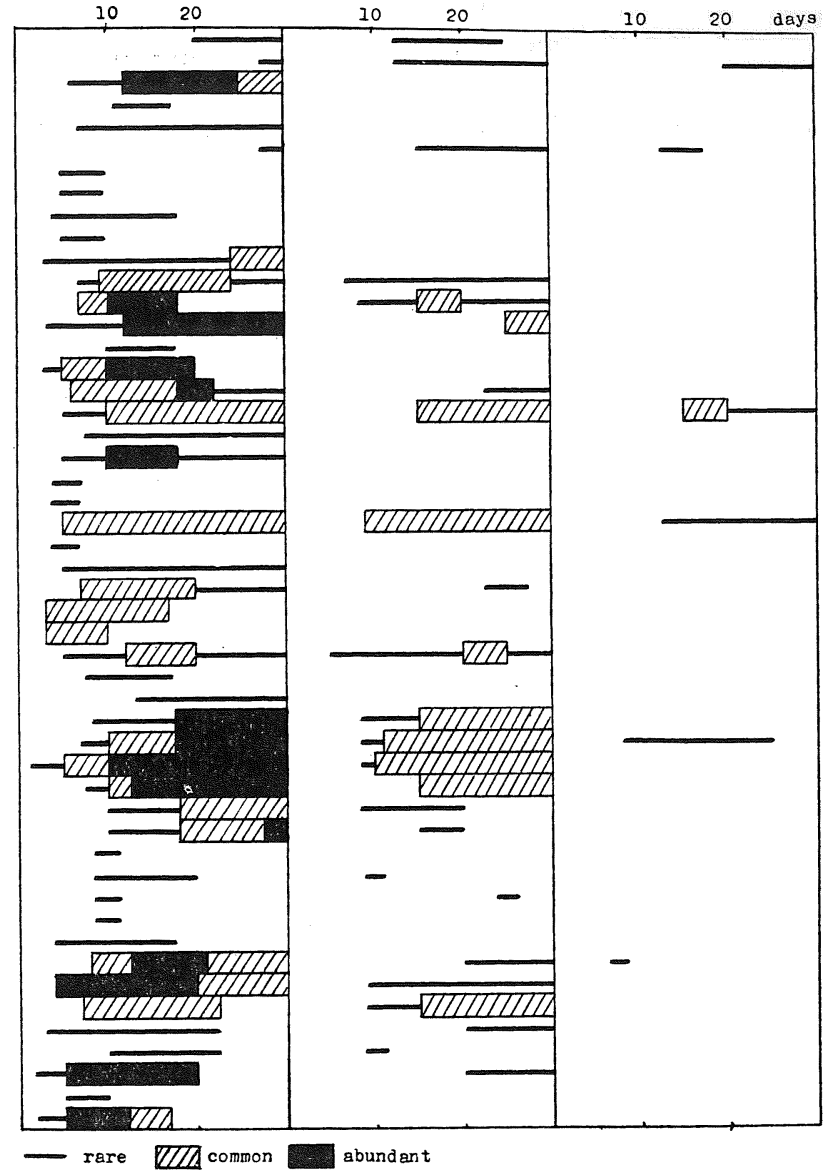

Fig. 26. Observations of the occurrence of plankton from the bottom mud of pond No. 2 (Minamimonzen-ike) at Toyonaka City.

Observation I : A case that water was poured into the bottle at once after a piece of mud was collected.

Observation II : A case that water was poured into the bottle after the mud was naturally dried in the laboratory during a week.

Observation III : A case that water was poured into the bottle after the mud was naturally dried in the laboratory during 2 weeks. 
from the mud. However, Rotifera, Cepopoda, Cladocera, Bacillariophyta and Chlorophyta, all of which are usually found at the surface layer, could also be detected, though their occurrence was of short duration in every case.

RotIFERA: A week after the flooding of vessels with distilled water, various species belonging to Rotifera occurred all at once. They were Erachionus angularis, Keratella cochlearis, Mitylina sp. and Asplanchna priodonta, all of which are all supernatant species usually found in a pond. The rest occurred were crawling species, such as Diplax trigona, Rotifera vulgaris and Rotifera actinurus, of which the last-named has the greatest frequency and the longest duration of occurrence as well as the largest number of individuals.

Cladocera: Moina macrocopa occurred following to Daphnia pulex. A week after the start of the experiment a few individuals appeared and had about a week to live. Its resting eggs were obtained from the mud in other vessels employed for the experiment.

Copepoda : Cyclops sp. occurred on the third day in one case, and on the tenth day in another, after the flooding of the vessels with distilled water. In most cases, however, it is after the lapse of about three weeks when an enormous occurrence of it could be detected. Eodiaptomus japonicus occurred abundantly in other vessels and lived for a long time.

Protozos : Ciliata and its kindred appear in large numbers. The predominants were Euplotes charon, Paramoecium caudatum, Glaucoma pyriformis, Stylonicha sp., Colpidium sp., Spirostomum ambigunm and others. The rest appeared were Lionotus fasciola, Vorticella campanula, Halteria grandinella, Trachelus sp., Euchelys sp. and Flexiphyllum sp, and a number of unidentified species were also found mixed with them. Such loricated amoebae as Difflugia corona, D. sp., Centropyxis aculeata and Arcella vulgaris were also observed crawling on the surface of the mud. They had some peculiar differences in their time of occurrence.

Flageltata: Trachelomonas ensifera and Euglena acus began to occur two days after the filling of the vessels with distilled water, though they were comparatively short-lived. Phacus pleuronectes, Euglena viridis, Euglena sp, Surirella elegans and others were also seen, though the frequency of their occurrence was rather low.

BaCILLARIOPHYTA: On the surface of the mud in the vessels were founded the remains of various diatom species, so that it was at first difficult to distinguish between the living and the dead. But after the lapse of a week, Pinmularia viridis, Stauroneis phoenicenteron, Navicula cryptocephala, Nitzschia palea, Synedra ulna and others began movements, which made them the distinction easier. Even if they do not move, their restoration from desiccation can be evidently recognized, for the yellowish green protoplasm that remained hitherto extremely reduced and plasmolysed gradually fills their cells. The remains of Melosira granulata were particularly plentiful, but, as compared with other species, the determination of its restoration was successful somewhat later, i. e. two weeks after the beginning of the experiment. Although their occurrence in low frequency, there could also te 
detected Navicula viridis, Cymbella turgida, Cymatopleura solea, Navicula interupta, Diploneis ovalis, Rhopalodia gibberula and others. Besides these, Fragilaria sp., Gyrosigma acuminatum and Epithemia sp. were found, though not determined to be living or dead.

Chlorophyta: There were found a few species belonging to Chlorophyta, Closterium acerosum and Scenedesmus spp. having the highest frequency of occurrence. All of them were those represented in $\alpha$-mesosaprobic waters. Pediastrum simplex was detected three times, and Closteroposis sp. twice.

Mrхорнита: The most numerous were Aphanocapsa sp. and Oscillatoria limosa; Ankistrodesmus falcatus was the next in number. Oscillatoria princeps was seen only sporadically.

\section{DISCUSSION AND CONSIDERATION}

In the foregoing chapters the writer has described the results obtained from his comparative studies of the pond groups in various parts of Japan and from his field investigations of both the vertical distribution of physical and chemical factors as well as the diurnal and seasonal variations of water conditions and plankton. This chapter is intended for further critical inquiry into environmental conditions of 'tame-ike' ponds, with a view to make clear the relation between such environmental conditions and planktonic organisms, and also the characters peculiar to all these ponds.

\section{ENVIRONMENTAL CONDITIONS AND HYDROBIOLOGICAL CHARACTERISTICS}

a) Principal Environmental Factors and Characteristics of Metabolim

Conditions Requisite to the Distribution of 'Tame-ike' Ponds: Unlike natural ponds, 'tame-ike' ponds are mostly constructed for the human requirements, so that their distribution is rather limited to a number of particular regions. Since nearly all of them are irrigation ponds, they have a very close relationship with the distribution of paddy-fields. Accordingly, rice cultivation is little to be seen in areas of low temperatures at higher latitudes and in barren volcanic localities of low water-holding capacity. Even where paddy-field is highly developed, there is little need of constructing 'tame-ike' ponds, so long as some water sources such as rivers and lakes can be found for irrigation or there is much rainfall. In such places, 'tame-ike' ponds are very few. The more developed the rice cultivation is and the more storage of water is required to provide against the shortage of irrigation water in summer time, the higher the density of the distribution of 'tame-ike' ponds is to be found. The typical examples in this connection are the coastal areas of the Inland Sea, the belt of land along the coast of the Japan Sea, and some inland basins. 
Correlation between the Environmental Conditions of 'Tame-ike' Ponds: The interrelation between the conditions of lakes and factors affecting the metabolic changes in them were shown by Rawson (1956). As compared with lakes, however, 'tame-ike' ponds are small in area and mostly $2 \sim 3 \mathrm{~m}$ deep, with little or no catchment areas and with drainage whenever it is necessary. 'Tame-ike' ponds, therefore, are considerably different from lakes in the effects of their environmental factors upon the water quality and planktonic organisms. The conditions and factors pointed out by $\mathrm{R}_{\mathrm{AWSON}}$ may be important with regard to lakes, but the same factors seem always to be not applicable likewise to 'tame-ike' ponds. Such conditions and factors with regard to various pond groups will be discussed below.

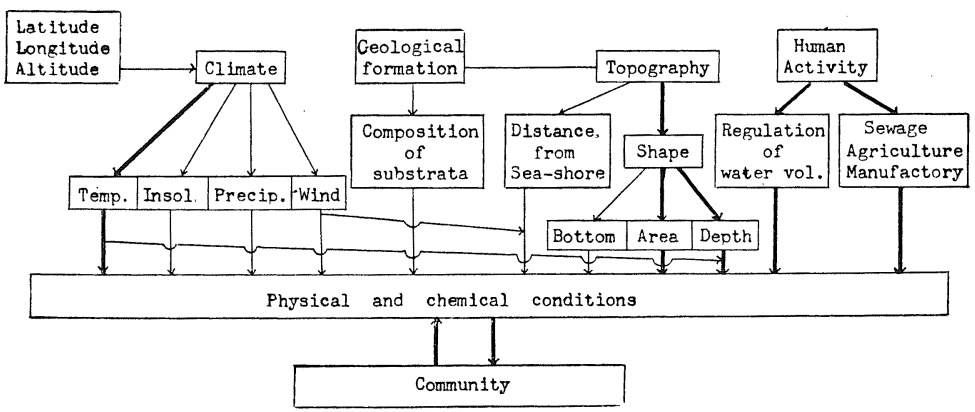

Fig. 27. Diagram of the principal environmental factors and their correlation.

The environments of 'tame-ike' ponds are divided broadly into two main categories, natural and artificial. The first is then subdivided into topography, geology and climate, while the latter into artificial contamination and regulation of water volume. The smallness of water-basin of a 'tame-ike' pond must come first as the faztor to determine its character. This is becuase the change of factors belonging to each category which determine condition of a 'tame-ike' pond has an immediate effect upon its water quality, leading physically and chemically to the life of organisms in the pond. It must, however, not be forgotten as one of the important factors that the increase or decrease in biotic production as well as in the sedimentation and decomposition of their remains have also given much effects to the physical and chemical changes of water. With all these interrelations taken into consideration, the characters of plankton of 'tame-ike' ponds will be discussed.

\section{b) Topographical Characteristics}

Setting apart the large dams built in recent years, there might have a limit to the human labour, technical skill and financial resources to be expended upon the 

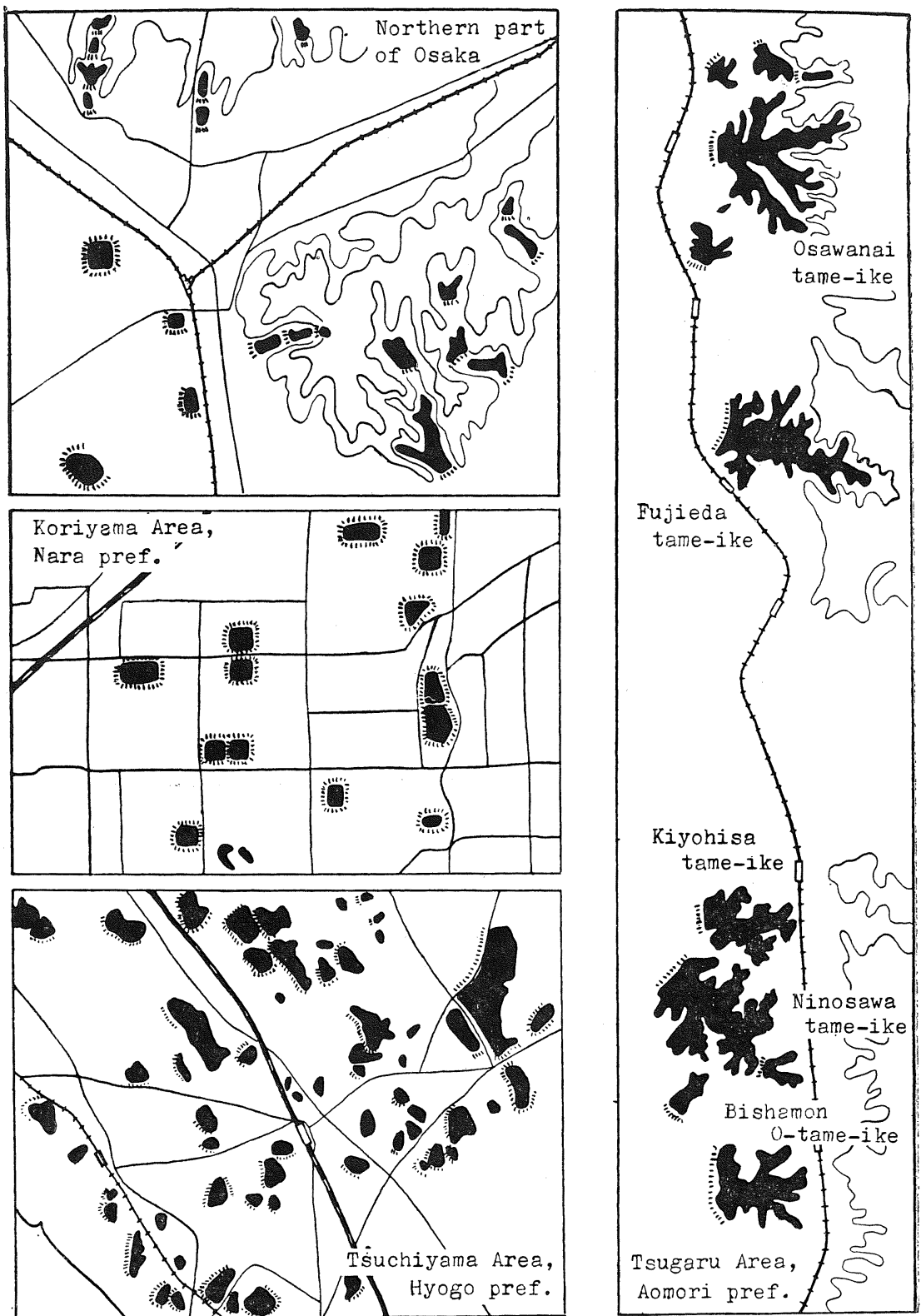

Fig. 28. The morphological characters (1). The various shapes and arrangements of 'tame-ike' ponds. 
construction of 'tame-ike' ponds. Such ponds, therefore, have some characters common to them. In other words, they are all very small both in superficies and depth, and the amount of stored water is usually not so large. And these :are the chief reasons why a 'tame-ike' pond and a lake are so different from each other in their respective characters.

Morphological Aspects of the Water Easins of 'Tame-ike' Ponds: In the mountainous areas and on the tablelands, most ponds are constructed by damming up the eroded valleys. Some of them are long and narrow in shape, and three or four ponds often lie arranged at short intervals. When two valleys are dammed up together, the ponds thus formed are V- or Y-shaped. When ponds are formed out of a number of valleys, they show a dendritic pattern. Both on the diluvial tablellands and in the mountains along the coast of the Inland Sea, most ponds are either small-sized or medium-sized, lying close each other and V or $\mathrm{Y}$ in shape. The ponds in the plains are constructed either by excavation or embankment, and are mostly circular or square in shape. Fig. 28 shows some examples of the typical ponds in different forms.

Area and Depth: Although various sizes, the area of 'tame-ike' ponds is $0.3 \sim 0.5 \mathrm{~km}^{2}$ in its maximum, and very much limited as compared with that of lakes. Koyano-ike, Zuiga-ike (Hyôgo pref.), Sendai-ike (Kagawa pref.) and Kumeda-ike (Osaka pref.) and others are large-sized ponds lying on the flat lands, while on the tablelands where ponds are constructed by damming up valleys, Ôsawanai tame-ike, Fujieda tame-ike, Bishamon ô-tame-ike and Ushigata-ike (Aomori pref.) are the representatives. Such large-sized 'tame-ike' ponds, however, are rather few, most of the ponds being only small-sized or medium-sized. 'Topographically, the 'tame-ike' ponds on the flat lands have necessarily flat bottoms while those on the tablelands or in the mountains are deepest behind the bank where they were dammed up, becoming shallower upward from there; therefore, they have slanting bottoms. Fig. 29 shows the results of soundings made in a number of ponds in and around Osaka City.

As the ponds on the flat lands are flat-bottomed, aquatic plants can grow well, covering the surface of water. It is not seldom seen that even the central part of the surface is hidden by such aquatic plants as Trapa natans, Brasenia purpurea, Nymphoides indicum, Potamogeton Franchetii and Sirpus mucroratus. Accordingly, there are found many plankton species that live among these aquatic plants. There is usually an increase of production of higher aquatic plants, from which more peaty materials are sedimented. In the dammed-up ponds, on the contrary, aquatic plants are found chiefly in the shallower part and forked-off part, very few or none of them growing in the deeper part. It is sometimes observed, however, that these aquatic plants are invading gradually toward the deeper part. Although the dammed-up ponds have an inflow of water from the neighbouring fields under cultivation, trophic degree is generally less advanced in them than in the ponds on the flat lands.

The shallowness is one of the important factors that distinguish ponds from 
1961]

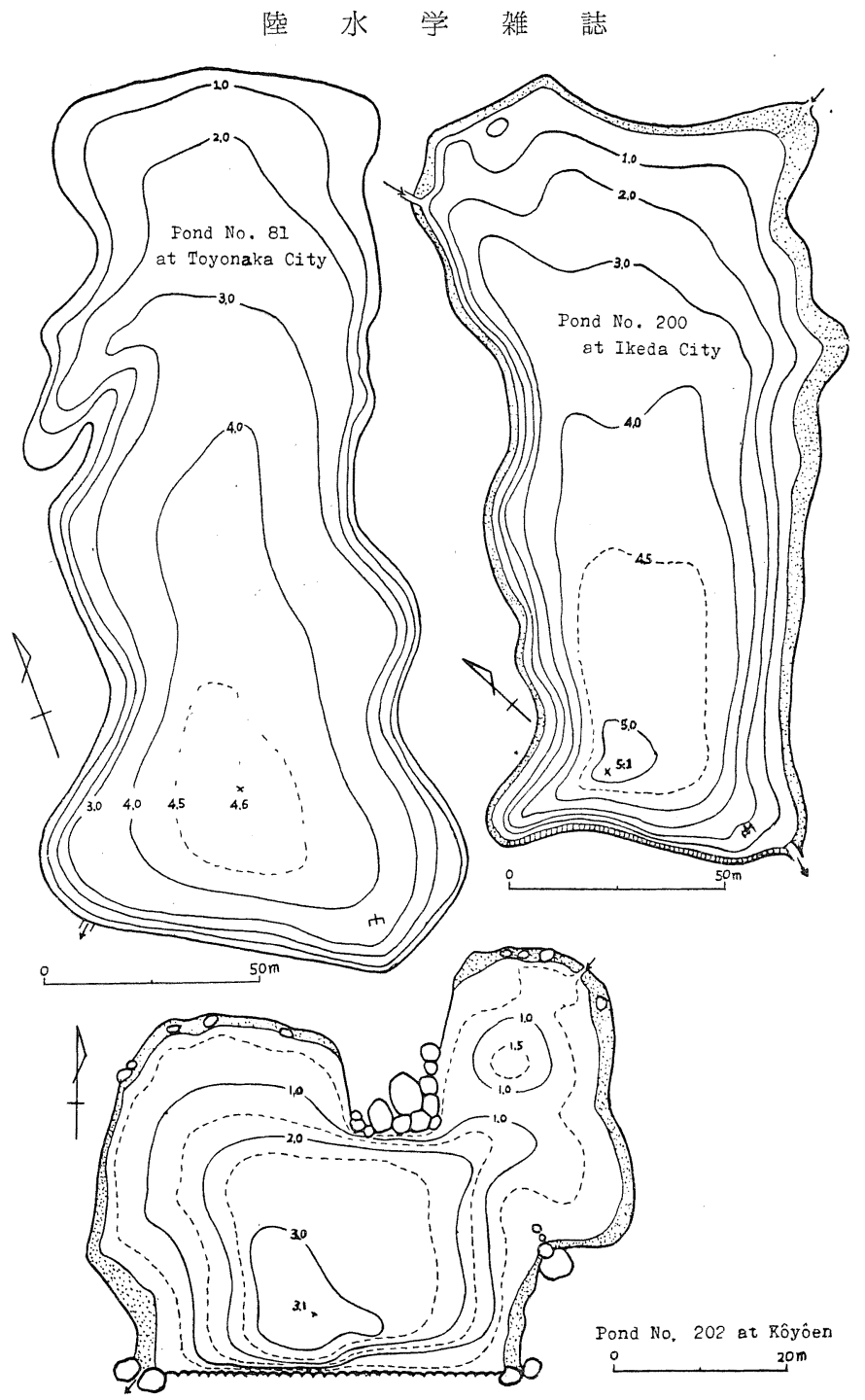

Fig. 29. The morphological characters (2). Bathymetric maps of 'tame-ike' ponds in the suburbs of Osaka City.

lakes regarding the water quality as well as plankton not only in their composition but also in their diurnal and seasonal fluctuations. This will be dealt with again later on. 


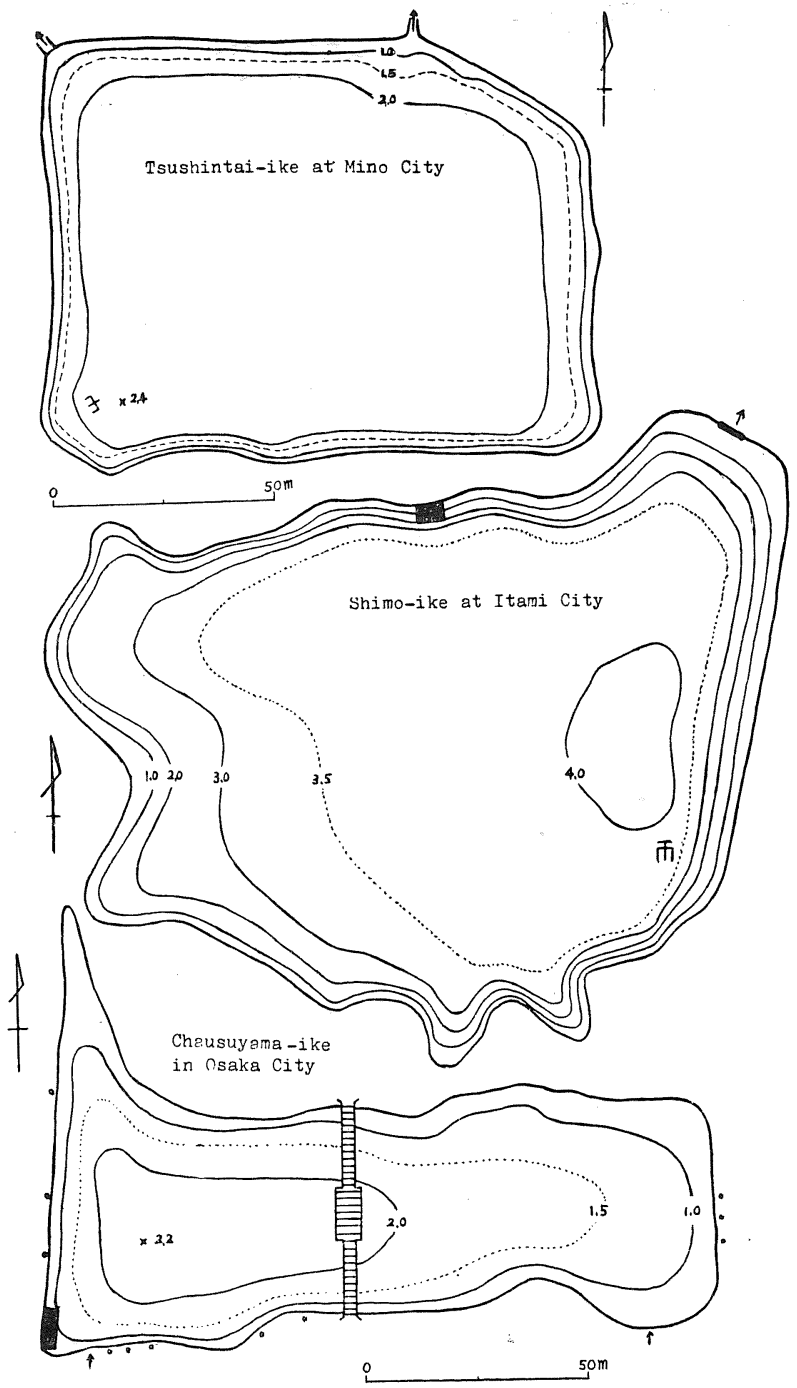

Fig. 29. Continued.

Summary of Morphological Aspects: Lacustrine typology is based primarily on the origin of each lake, but in this respect, ponds are much simpler than lakes, since they have no other origin than artificial construction without any exception. 
However, there are what may be called secondary 'tame-ike' ponds which utilize natural ponds so as to regulate the water volume by means of certain artificial devices. For instance, Nikkô-ike and Mizujiri-ike (both in Tottori pref.) store water in winter, but from spring to autumn they are drained and their bottoms are turned into paddy-fields. Together with these, 'tame-ike' ponds are classified according to their construction sites and morphological characters.

\section{c) Geological Characters and Plankton Communities}

HARADA (1934) and KoBAYASHI (1951) reported the results of chemical analyses of the water samples collected from a great number of rivers in Japan. MASON (1958) dealt with the chemical composition of sedimentary rocks and the effect of each ion upon the $\mathrm{pH}$ value of water. As will be known from these studies, the differences in the properties of rock and soil forming the water basins of ponds are presumed to affect their water quality. But in the three pond groups, lying on the granitic, the palaeozoic and the diluvial formation respectively in the northern part of Osaka, the amounts of dissolved substances were very small and no distinctive difference attributable to geological effects could be observed. Moreover, the flora and fauna were scanty in these ponds, not only in the number of species but also of individuals. The comparison made between the pond groups lying both on the diluvial tablelands and in the alluvial low-lying areas along the coasts of the Inland Sea brought to our notice that trophic degree is distinctly advanced in the latter groups than in the former.

From the results of chemical analyses of water samples obtained from various pond groups in Japan, it is known that $\mathrm{SiO}_{2}, \mathrm{SO}_{4}=\mathrm{Ca}^{++}$and $\mathrm{Fe}^{++}$respectively has a distinctive local character. The localities rich in $\mathrm{SiO}_{2}$ are the diluvial tableland in the northern part of Osaka, the eastern part of the Island of Okino-shima, and the Island of Hachijô-jima; those rich in $\mathrm{SO}_{4}=$ the Island of Rishiri-tô, the alluvial formation in the southern part of Osaka, Kamogata in Okayama pref., and Takamatsu and Marugame in Kagawa pref.; and those rich in $\mathrm{Ca}^{++}$the islands such as Okinoerabu-jima, Yoron-tô, Sadoga-shima (I. and III. Districts.), Hachijô-jima, Tsuchiyama in Hyôgo pref., Kamogata in Okayama pref., Takamatsu and Marugame in Kagawa pref., and Matsuyama in Ehime pref. Whether the dissolved $\mathrm{Fe}^{++}$content is large or small is not so much because of the local character as due to the other environmental factors of each pond found in the same group.

Ca-ion: Generally speaking, the inland waters either in the areas formed of limestone, dolomite and gypsum or in the tropical districts composed of rised coral reefs are rich in $\mathrm{Ca}^{++}$, which is dissolved by ground and rain waters in the presence of $\mathrm{CO}_{2}$. As has already been stated, Okinoerabu-jima and Yoron-tô are rised coral reefs, on which the ponds on the former showed the mean $\mathrm{Ca}^{++}$ value of $30.7 \mathrm{mg} / l$, while those on the latter that of $33.5 \mathrm{mg} / l$. Okinoerabu-jima has many stalacite grottos called 'Kuragô' or literally a dark river, so that the $\mathrm{Ca}^{++}$content is still higher in the underground water, its average value being $45.6 \mathrm{mg} / \mathrm{l}$. In some grottos, the values exceeded $50 \mathrm{mg} / \mathrm{l}$. 'Tame-ike' ponds on 
Table 24. Morphological characters of

\begin{tabular}{c|c|c|c|}
\hline Type & Construction & Area of distribution & Shape \\
\hline $\begin{array}{c}\text { Semi-artificial } \\
\text { pond }\end{array}$ & $\begin{array}{c}\text { Eroded valley, } \\
\text { partially dammed-up }\end{array}$ & $\begin{array}{c}\text { Mountains, } \\
\text { tablelands }\end{array}$ & $\begin{array}{c}\text { Long, narrow, } \\
\text { V- or Y-shaped, } \\
\text { dendritic pattern }\end{array}$ \\
\cline { 2 - 4 } $\begin{array}{c}\text { Artificial } \\
\text { pond }\end{array}$ & $\begin{array}{c}\text { Excavated or } \\
\text { embanked }\end{array}$ & $\begin{array}{c}\text { Flatlands, } \\
\text { alluvial low-lying } \\
\text { lands }\end{array}$ & $\begin{array}{c}\text { Circular, square, } \\
\text { semi-circular }\end{array}$ \\
\hline $\begin{array}{c}\text { Secondary } \\
\text { pond }\end{array}$ & $\begin{array}{c}\text { Natural pond } \\
\text { equipped with } \\
\text { pumping-system }\end{array}$ & Mountains, \\
dunes, flatlands
\end{tabular}

the volcanic island Hachijô-jima showed $\mathrm{Ca}^{++} 46.95 \mathrm{mg} / l$ and the marshy pools at the summit of Mt. Hachijô-fuji $54.3 \mathrm{mg} / l$. As compared with lakes abroad, however, the lakes and ponds in Japan may be said to have by far less $\mathrm{Ca}^{++}$ content. Yoshimura proposed that ponds having water more than $50 \mathrm{mg} \mathrm{Ca}^{++} / \mathrm{l}$ should be regarded to be gypsotrophic facies and pointed out the ponds of this kind in some parts of Taiwan (Formosa). From the data on hand, however, the writer failed to find how far these ponds have an inhibitory action upon the organisms as a disharmonious types of ponds.

The writer is interested with the ponds in which the $\mathrm{Ca}^{++}$is rather scanty. Holopedium gibberum, which was found in the ponds Nos. 81 and 82 in Osaka pref., is said to occur in lakes and ponds where there is paucity of $\mathrm{Ca}^{++}$; its distribution is believed to be chiefly restricted to the Kurile Islands, Saghalien and the northeasten districts of the main island of Japan. Holopedium gibberum, however, is also reported from certain lakes, e.g. Lake Kizaki-ko in Central Japan and even from Mi-ike at the foot of Mt. Kirishima (in the water layers colder than $8^{\circ} \mathrm{C}$ ) in southern Kyûshû. From these findings, it may be said that this species is a cold-water stenothermal as well as a torrelant of oligotrophic type of lakes and ponds. The occurrence of this species in the shallow ponds ( $5 \mathrm{~m}$ deep) on the diluvial formation around Osaka City may be said to show the southernmost limit of its distribution.

Among the phytoplanktonic organisms, desmids are very abundant in the pond groups lying in the southern part of Osaka and in the Hôjô district, Hyôgo pref. The fact that desmid species are especially numerous in the ponds of both weak acid and scanty in lime suggests some relations between $\mathrm{Ca}^{++}$and desmids.

Fe-ion: Fe-ion content in 'tame-ike' ponds is generally less than $1 \mathrm{mg} / l$. This is because $\mathrm{Fe}^{++}$precipitates in the form of insoluble ferric oxide or hydroxide when the water is neutral or acid and plenty of oxygen. In various areas, however, there are not a few ponds where the $\mathrm{Fe}^{++}$content is remarkably large. The reason may be that the particles of clay and humus in water play the part of 
'tame-ike' ponds.

\begin{tabular}{|c|c|c|c|}
\hline \hline \multicolumn{2}{c|}{ Morphological characters } & Bottom & Number \\
\hline Size & Depth & Inclined & $\begin{array}{c}\text { Arranged in } \\
\text { a row at } \\
\text { short intervals }\end{array}$ \\
$\begin{array}{c}\text { Generally small } \\
\text { or medium size }\end{array}$ & $\begin{array}{c}\text { Commonly } 4 \sim 7 \mathrm{~m} \\
\text { partially } 10 \mathrm{~m}\end{array}$ & Flat, dish-shaped & Isolated \\
\hline $\begin{array}{c}\text { Small, medium, } \\
\text { partially large }\end{array}$ & Shallow, 2 3 m & Various & Isolated \\
\hline Various & Various & F & \\
\hline
\end{tabular}

protective colloid for $\mathrm{Fe}^{++}$. In summer, iron oxide or hydroxide is also dissolved in water in the form of $\mathrm{Fe}^{++}$as a result of oxygen deficiency in the bottom layer and is diffused up to the surface layer. For instance, pond No. 198 in the northern part of Osaka is rich in humus and deficient in oxygen even up to the surface layer, and both pond No. 6 at Takamatsu and pond No. 22 in Kamogata are nearly in the same conditions as the above. In Nigori-ike pond on the diluvial formation in the south of Osıka and also in pond No. 11 at Matsuyama, the richness of $\mathrm{Fe}^{++}$may probably be accounted for by the clayey turbidity. KuRASHIiE (1934) pointed out the promoting effect of $\mathrm{Fe}^{++}$on the proliferation of diatoms ; HARVEY considered $\mathrm{Fe}^{++}$to be an important factor for the promotion of growth of some species of organisms. On the other hand, Uspensky (1927) has stated that, if small in quantity, $\mathrm{Fe}^{++}$is a requisite substance for the growth of organisms but is inhibitory effect when it is excess in quantity. Yossimura (1933, 1937) has designated that, when the $\mathrm{Fe}^{++}$content of more than $5 \mathrm{mg} / l$ in the water, that body of water is siderotrophic in the disharmonious types. The ponds in which the $\mathrm{Fe}^{++}$content is more than $5 \mathrm{mg} / l$ are as follows.

Table 25. Number of species in the siderotrophic ponds $(\mathrm{Fe}, \mathrm{mg} / l)$.

\begin{tabular}{|c|c|c|c|c|c|c|c|c|c|c|c|}
\hline & $\mathrm{pH}$ & $\mathrm{O}_{2}$ & $\mathrm{Fe}$ & Cope & Clad. & Rotif. & Cyano. & - Bacil. & Chlor. & Prot. & Total \\
\hline $\begin{array}{l}\text { Pond No. 198, north., } \\
\text { Osaka }\end{array}$ & 6.3 & 0.3 & 10.3 & 1 & 1 & 3 & 2 & 7 & 3 & 4 & 21 \\
\hline $\begin{array}{l}\text { Nigori-ike, Sennan, } \\
\text { Osaka }\end{array}$ & 6.3 & - & 10.0 & 2 & 2 & 2 & 0 & 1 & 8 & 1 & 16 \\
\hline $\begin{array}{l}\text { Pond No. 22, Kamo- } \\
\text { gata, Ukayama }\end{array}$ & 6.8 & - & 7. 0 & 1 & 1 & 0 & 0 & 0 & 1 & 1 & 4 \\
\hline $\begin{array}{l}\text { Pond No.6, Takama- } \\
\text { tsu, Kagawa }\end{array}$ & 7.3 & - & 18.0 & 2 & 3 & 11 & 2 & 3 & 6 & 9 & 36 \\
\hline $\begin{array}{l}\text { Pond No. 11, Matsu- } \\
\text { yama, Ehime }\end{array}$ & 7. 7 & - & 5.0 & 1 & 2 & 5 & 1 & 0 & 1 & 1 & 11 \\
\hline
\end{tabular}


Pond No. 22 at Kamogata, Okayama pref. shows that the plankton production is remarkably limited, but the inhibitory effect of $\mathrm{Fe}^{++}$is hardly detectable in the other ponds. This problem will be subjected to further discussion.

Turbidity due to Clay: Whitish or brownish turbidity is not seldom seen in the ponds lying in the valleys of mountains or on the diluvial tablelands. Yoshimura designated such ponds of remarkably high turbidity to belong to the argyllotrophic facies under the disharmonious type. However, owing to the insufficient data of quantitative analyses at his time, he had no source to take and use the degree of transparency in this connection. In their investigation of the Yangtze delta, Miyadi, UÉNo and Tomita (1943) found that the transparency of those inland waters was usually $20 \sim 30 \mathrm{~mm}$ and seldom exceeded $1 \mathrm{~m}$. They pointed out that (1) neither floating nor submerged weeds were found growing there, (2) phytoplanktonic organisms were either depauperated or generally very few in number, and that (3) Diaphanosoma, Diaptomus, Cyclops and others were chiefly found. They accepted the Yoshlmora's argyllotrophic type. The writer made a comparative study of ponds of remarkable high turbidity, from which the results obtained are tabulated below.

Table 26. Number of species in the argyllotrophic ponds.

\begin{tabular}{|c|c|c|c|c|c|c|c|c|c|c|}
\hline & $\begin{array}{c}\text { Colour } \\
\text { of water }\end{array}$ & $\left|\begin{array}{c}\text { Rooted } \\
\text { aquatic } \\
\text { plants }\end{array}\right|$ & Cope & Clad & Rotif & Myxo. & . Bacil. & Chlor. & Frag. & Total \\
\hline $\begin{array}{l}\text { Temporary pond } \\
\text { at Kôyôen }\end{array}$ & Brownish & Nil & 1 & 0 & 0 & 0 & 0 & 0 & 0 & 1 \\
\hline $\begin{array}{l}\text { Pond No. } 202 \\
\text { at Kôyôen }\end{array}$ & Whitish & Ni1 & 3 & 2 & 2 & 0 & 0 & 0 & 2 & 9 \\
\hline $\begin{array}{l}\text { Ushitaki-ike } \\
\text { at south Osaka }\end{array}$ & Whitish & Nil & 3 & 1 & 2 & 0 & 0 & 1 & 0 & 7 \\
\hline $\begin{array}{l}\text { Pond No. } 42 \\
\text { at Saijô }\end{array}$ & Brownish & Nil & 0 & 2 & 1 & 0 & 0 & 0 & 0 & 3 \\
\hline $\begin{array}{l}\text { Pond No. } 4 \\
\text { Sadoga-shima }\end{array}$ & Brownish & Nil & 1 & 2 & 0 & 0 & 11 & 2 & 0 & 15 \\
\hline $\begin{array}{l}\text { Pond No. } 15 \\
\text { Sadoga-shima }\end{array}$ & Whitish & $\begin{array}{l}\text { Potamo } \\
\text { geton }\end{array}$ & 2 & 3 & 0 & 1 & 8 & 6 & 0 & 20 \\
\hline
\end{tabular}

In all the ponds except Nos. 4 and 15, the growth of phytoplankton is distinctly checked. Even aquatic plants are prevented from growing in these ponds. It may be considered that suspended clay particles make the penetration of light extremely difficult, and as a result of its absorption by organisms, there prove disadvantageous to their existence. But even in such ponds as Nos. 4 and 15 in Sadoga-shima where the turbidity of water is remarkably high, phytoplanktonic organisms are often found abundantly. Particularly in the case of No. 15, its shallowness (only $1 \mathrm{~m}$ ) may make possible phytoplankton and other higher aquatic plants to be produced abundantly. In a temporary pool found in the granite quarry at Kôyôen, the water was extremely brownish in color and only a single species Mesocyclops leuckarti was found in abundance. From all these findings, though 
argyllotrophic type may be acceptable, the qualitative differences and grade of turbidity as well as the mechanism of the effect of clayey particles upon organisms still remain for study.

\section{d) Climatic Conditions and Plankton Communities}

The most important factor is atmospheric temperature whose changes are directly related with plankton through the temperature of water. Moreover, having been related with the production of organisms and the rate of their decomposition, it produces many and varied effects not only in the nutritive matter but also in the physical and chemical characters of pond waters, upon which the quality and quantity of plankton depend greatly.

The Areas of High Latitudes and of High Altitudes: The lakes and ponds in the Kuriles, Saghalien and Hokkaido were already investigated by KIKUCHI (1933), Orada (1934), UÉNo (1934, 1935), Mryadi (1935, 1937) and HADA (1936). The writer (1958) also made a limnological investigation of Rishiri-tô Island and Hokkaidô, and obtained some knowledge on the characteristics of the lakes and ponds peculiar to such cold northern districts. Menuushoro-numa and Otadomarinuma on the Island of Rishiri-tô showed a dystrophic nature, with a brownish colour, the $\mathrm{pH}$ value of $4.3 \sim 5.6$, and the $\mathrm{KMnO}_{4}$ consumption of more than 70 $\mathrm{mg} / l$. They are characterized by peat deposits, which turn the water colour brown and increase the $\mathrm{KMnO}_{4}$ consumption. These distinctive characters become less conspicuous in the ponds further south, but they are still observable in some ponds lying in the northeastern districts of Japan. Most of the ponds lying in and north of Hokkaido are natural in their origin, but in Aomori, Akita and Yamagata prefectures, not a few 'tame-ike' ponds are found to retain such peculiar characters with peat deposits at the bottom. A good example is Ôtori Misumiike, which is situated still further south and at an altitude of $1000 \mathrm{~m}$ in Yamagata pref. The investigation of this pond (Mizovo et al, 1959) has shown that it has a close resemblance with the low-lying ponds on Rishiri-tô Island, with the pH value 4.4, a dark brown colour (methylorange colour scale 5 ) and reddish brown humic deposits on the bottom. This phenomenon is probably due to the similarity of climatic conditions. Viewed from the typological criterions, such ponds in the peaty localities and marshy pools at the summits of high mountains may belong to the dystrophic type.

According to the hitherto published reports on the plankton in the cold northern districts, there are no particular plankton species tolerable to the dystrophic ponds, and only those of the common and cold-resistant species which are tolerable to humose waters of strong acidity may possibly live in these ponds. The species found in the two ponds on Rishiri-tô Island were : Cladoofra :- Daphnia longispina hyalina, Bosmina longirostris and Chydorus sphaericus; COPEPODA :- Acanthodiaptomus pacificus and Eucyclops serrulatus; RoTIFERA:- Keratella cochlearis and K. cochlearis tecta ; Protozoa :- Diffugia sp. ; Bacillariophyta :- Melosira granulata; and ChLorophyтA :- Mougeotia sp. In Ôtori Misumi-ike pond, Yama- 
gata pref. the domiant species were Acanthodiaptomus pacificus, Daphnia rosea, Tropocyclops prasinus, and besides these, Monostyla crenata, M. pygmae, Euchlanis dilatata, Conochilus unicornis, Difflugia corona and Tintinnidium sp. were found only scantily. Hrrano (1959) recorded the following species from the same pond as the dominant phytoplanktonts, Dinobryon cylindricum, Gymnodinium neglectum, Glozocystis planctonica and Tetraspora limnetica. From its neighbouring Sphagnum marshes, he determined also 24 algal species, of which 16 were referable to diatoms. HADA (1937) made a detailed study of plankton fauna and flora in the Tokotan peaty bogs in Hokkaido. The species described by him are pretty numerous in number, and those of abundant occurrence are : ROTIFERA :- Keratella cochlecris, Synchaeta stylata and Polyarthra trigla, followed by Synchaeta pectinata, Filinia passa and Pedalia mira; Flageldata :- Synura uvella, Dinobryon sertularia, Peridinium pussilum, Euglena acus and Pandoring morum ; BaclldarioPHYTA :- Melosira varians, Fragilaia sp., Surirella biserata and S. robustia; Calorophyta :- Mougeotia sp. and Myхорнyта :- Oscillatoria limosa. There are more zooplanktonic species and less phytoplanktonic ones. The same author stated that all the planktonic organisms propagated in the summer stagnation period and were very scanty in winter. The neutrality of this pond water, $\mathrm{pH}$ $6.0 \sim 7.2$ in its surface layer, may lead to the greater abundance of planktonic species.

The Areas of Low Latitudes: Mryadi (1935) and UÉno (1935, 1936) investigated the inland waters in Taiwan (Formosa), and Mlyadi, UÉno and Tomita (1943), and Mashiko (1935) those in Southern China where there are geographically in proximity to the southern part of Japan. The Osaka City Natural History Museum (1956) published the expedition reports regarding the inland waters on the Tokara Islands. The writer (1957), who visited the northern group of the Ryûkyû Islands to investigate 'tame-ike' ponds, found that they did not receive so much effects of seawater due to typhoons as in the characters of inland waters peculiar to the tropical or coral island in the south. These islands lie between the $27^{\circ}$ and $29^{\circ}$ N. lat., and at the southern extremity of the Japanese Islands. The water temperature at the surface layer early in August showed $30 \sim 39^{\circ} \mathrm{C}$. The atmospheric temperature will seldom fall below $15^{\circ} \mathrm{C}$ even in winter when viewed from the plants growing there.

Most of the plankton animals and plants consist of common species which are nearly the same as those found all over Japan. If there are any species worth particular to mention, it is Moina dubia which was found abundantly in N. i nitukeike pond on Okinoerabu-jima; it is said to be distributed as far south as Taiwan (Formosa). Ceriodaphnia rigaudi was also found in pond $\mathrm{F}$ on Yoron-tô Island. In addition to these, Brachionus caudatus f. apsteini, Lecane curvicornis and others, all belonging to Rotifera, were found there. In the phytoplanktonic species, Oscillatoria princeps and O. Iwanoffiana were found.

The Central Warm Temperate Districts: In the foregoing chapter, the temperature of water were dealt with regarding its remarkable diurnal and seasonal 
fluctuations. In summer, the water temperature rises to more than $25^{\circ} \mathrm{C}$ from the surface to the bottom, and in winter it comes down to $5 \sim 6^{\circ} \mathrm{C}$. Unlike lakes, no thermocline does not develope in ponds. In the Kinki, Chûgoku and Shikoku regions in the central and western parts of Japan, the plankton communities of ponds consist of mostly common species, showing a mixed existence of both boreal and austral species. The northern or cold-water boreal species recorded are as follows :

Scapholeberis mucronata Nos. 15 \& 21, Tsuchiyama, Hyôgô pref., Nov. 10. Acroperus harpae Misasagi-ike pond, South Osaka, Nov. 25.

Polyphemus pediculus Moat of Osaka Castle, March 19.

Acanthodiaptomus pacificus Shimohôjô, Tottori pref., Dec. 30.

Keratella quadrata No. 1, North Osaka, April 19 ; No. 8, North Osaka, March 18.

Kellicottia longispina Moat of Osaka Castle, March 19 ; No. 14, Kamogata, Okayama pref., Nov. 21.

Dinobryon divergens Kôriyama, Nara pref., April 15.

D. bavaricum

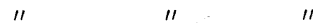

As Holopedium gibberum collected in pond No. 81 in the northern part of Osaka, some species are found even in June and July, There is however a general tendency that the estival species in Hokkaido and Tohoku usually appear in Central Japan between late autumn and early spring.

On the other hand, the followings are well-known as the austral species. Cladodera :- Daphnia magna, Ceriodaphnia rigaudi and Bosminopsis deitersi ; CगPEPODA :- Eodiaptomus formosus and Thermocyclops taihokuensis ; Rotrfera :Keratella valga, Polyarthra trigla, Brachionus falcatus, B. forficula, Pompholyx complanata and Trichocerca cylindrica. They are usually found in any pond in this region. As for the austral phytoplanktonic species, Hrrano (1943, 1950) pointed out the abundance of desmids in the ponds around Kyoto. In this connection, as has already been stated, the writer found in South Osaka and in Hôjô of Hyôgo pref. many southern species belonging to the genera Staurastrum, Micrasterias, Euastrum, Streptonema, Triploceras, Cosmarium and Xarthidium.

Such a mixed existence of both boreal and austral species may be chiefly due to the shallowness of water. In this region the rise of tempeature in summer and its fall in winter reach to the very bottom layer, so that there may become both frigid and tropical environments according to seasonal changes. In this connection, unlike Holopedium which is distributed along the central mountain range, and also unlike Micrasterias truncata which invades as far south as Yakumoga-hara marshes on Mt. Hira, it is worthy to note that southward invading of northern species in the ponds of flat-lands might have enlarged their range of distribution by occurring in winter. The ponds in the warm temperate region are characterized by the plankton not only rich in its number but also variable in its multiplication in different seasons of the year.

Dystrophic Po.lds in the Warm Temperate Areas: In the warm temperate areas, 
as in the cold northern districts, there are also a number of ponds rich in humus. Most of them lie on the alluvium and are surrounded by Phragmites and Zizania. There grow often Trapa natans, Brasenia purpurea and Nymphoides indicum as well as such floating-leaved plants Spirodela polyrhiza and Salvinia natans covering the surface. The water-colour is dark brown and the $\mathrm{KMnO}_{4}$ consumption is remarkably great. The depth of water is small, and the bottom mud is thick and full of humic materials. The $\mathrm{pH}$ value ranges from weak acid to neutral, but both the dissolved substances and the planktonic organisms are scanty. The origin of these dystrophic ponds in the warm regions may differ from those of similar nature in the cold northern districts. As the higher aquatic plants grow well in these ponds, favoured by rich nutritive salts and adequate warm climate, and also the production of other organisms increases enormously, the sedimentation of their remains always becomes excess beyond the rate of decomposition. Pond No. 198 in the northern part of Osaka, Yuino-ike pond on the Island of Okinoshima and pond No. 3 in Amagasaki may be typical examples of this kind.

Monsoon and Typhoon: It is known that 'tame-ike' ponds situated near the seashore have a greater $\mathrm{Cl}^{-}$content due to sea-breeze than the inland 'tame-ike' ponds. As has already been stated, this phenomenon was shown by YosHimura and Yamamoto, Matsudaira, Iwasaki, Sugawara and Takayanagi, all of whom made their studies both experimentally and analytically. Most of these studies were however confined to brackish water lakes, and very few reports concern the relationship between the wind-brought $\mathrm{Cl}^{-}$and the plankton in the inland waters which are completely isolated from the sea. According to Mashiko (1950) who took up this question in his investigation of the small 'tame-ike' ponds on the Island of Hegura-jima, Ryujin-ike pond situated on the sea-eroded terrace 5 $10 \mathrm{~m}$ above sea level showed $5730 \mathrm{mg} \mathrm{Cl}^{-} / l$ and another similar pond on the same island $3301 \mathrm{mg} \mathrm{C}-/ l$, being inhabited abundantly by brackish water copepods and rotifers, such as Palacyclopina nana, Pedalia fennica and Brachionus plicatilis. Judging from the results obtained, however, those pond groups on such islands and sea-side places may be said to receive the influence of monsoons or typhoons. Even those lying at a distance of less than several ten meters from the sea-shore rarely show as high as $100 \mathrm{mg} \mathrm{Cl}^{-} / l$, though it must be admitted that the $\mathrm{Cl}^{-}$ content is larger in the coastal ponds than in the inland ones and also in the pond groups on the west coast under the direct influence of monsoons than in those on the east coast. With the exceptions of the ponds which even though temporarily are invaded by sea water as a result of incoming groundwater, waves and adverse tide, and also of those which had once been of brackish water and now isolated from it, the writer is of the opinion that 'tame-ike' ponds originally constructed artificially remain always in fresh water. Accordingly, it is found that even in those ponds close to the sea-shore, the plankton consists of mostly freshwater species. But in those ponds which were connected with the sea in the past and isolated from it at present, a number of relic brackish water species are still found. 


\section{e) Vertical, Diurnal and Seasonal Variation of Water Qualities and Plankton Communities}

The observations stated above were in most cases made regionally all over Japan. Owing to the shallowness of ponds a two-dimensional observation in the ponds is allowable to some extent. But in order to ascertain further the characters of ponds, three-dimensional observation is necessary, with a view to find out how these pond-waters undergo physical and chemical changes vertically or how planktonic organisms are distributed in all the layers of water.

Even this, however, is not enough, for it reveals nothing but the characters of ponds at a given time. Both the environmental conditions of these ponds and the plankton communities therein are subject to constant changes, so that only when another factor, i.e. time factor is taken into consideration, it is possible to take another step forward in making clear the complete aspects of the dynamic ecosystems of ponds.

Selecting representatives out of the pond groups in the suburbs of Osaka, the writer tried to observe them not only in their three-dimensional aspects but also from the viewpoint of the diurnal and seasonal fluctuations in their ecosystems.

Water temperature : The rise and fall of water temperature in 'tame-ike' ponds are more marked than in lakes. In lakes even the amplitude of more than $10^{\circ} \mathrm{C}$ in the atmospheric temperature does not produce a difference of more than just $1^{\circ} \mathrm{C}$ or thereabouts in the water temperature. In 'tame-ike' ponds, however, when the atmospheric temperature changes by $7 \sim 8^{\circ} \mathrm{C}$, it instantly brings about a difference of more than $3^{\circ} \mathrm{C}$ in the water temperature. The diurnal changes in the vertical distribution of water temperature are not very conspicuous except at the surface layer of $0 \sim 1 \mathrm{~m}$, but when observed more closely, it is found that there is a tendency for the temperature to rise gradually, though very slightly, from the surface layer downward to the bottom layer.

In the summer stagnation period, most lakes in Japan form thermocline (metalimnion) usually at the depths of $5 \sim 20 \mathrm{~m}$, but not in 'tame ike' ponds, though there are seen a certain gradient of temperatures. In Shimo ike pond at Itami, the difference in temperatures between surface and bottom layers was $7 \sim 8{ }^{\circ} \mathrm{C}$ at the beginning of July, but in August, it decreased to $2 \sim 3^{\circ} \mathrm{C}$. This means that in a 'tame ike' pond 3 4 $\mathrm{m}$ deep the change in temperature at the surface layer can easily reach down to the bottom in a short time. At the same time the diurnal and seasonal changes of water temperature in 'tame-ike' ponds are remarkably different from those in lakes. Therefore, as stated already, a lake has a particular water layer of a certain depths at which northern planktonic species may propagate, while such propagation is limited to a particular season in a 'tame ike' pond. It may further be considered that southern planktonic species can best invade 'tame-ike' ponds in midsummer when a high temperature lasts for a considerably long period.

$\mathrm{pH}$ value: The $\mathrm{pH}$ value is generally alkaline in the daytime at the water layer 
that phytoplankton abound and is neutral or acid at the layers from middle down to the bottom. In the mountain 'tame-ike' ponds of oligotrophic type, the $\mathrm{pH}$ value is acid throughout, having little or no change and few or no diurnal fluctuations. As eutrophication advances and phytoplankton enormously increase, the difference in the $\mathrm{pH}$ value between surface and bottom becomes greater. In Shimo-ike pond at Itami, the $\mathrm{pH}$ value gradually lowered from 9.8 to 6.2, where, however, it again rose to 6.8 because of abundant growing Hydrilla verticillatc. In 1956 this pond happened to show an exceptional lowering of $\mathrm{pH} 4.2$ as a result of the decomposition of dead Hydrilla vertrcillata on its bottom. It may be said that the $\mathrm{pH}$ value of 'tame-ike' ponds, unlike that of lakes, varies considerably according to the slightest environmental changes, in which planktonic organisms affect it greatly.

Dissolved $\mathbf{O}_{2}$ : In the summer stagnation period, lakes are usually divided into three different layers, - epilimnion, metalimnion and hypolimnion-if entirely free from any organic and other oxidizable matters. When in an ideal condition, epi- and hypolimnion are saturated with $\mathrm{O}_{2}$, the metalimnion being often oversaturated with it. However, the assimilating process of rooted aquatic plants and phytoplankton becomes active in the epilimnion, where $\mathrm{O}_{2}$ saturation or oversaturation occur. From the thermocline downwards, $\mathrm{O}_{2}$ diminishes greatly and often becomes deficient or completely absent at the bottom layer. 'Tame-ike' ponds are different from lakes in this respect. Only in some of the oligotrophic mountain 'tame-ike' ponds, $\mathrm{O}_{2}$ is not saturated even all day long, while in the eutrophic ponds of flatland, the surface layer $0 \sim 1 \mathrm{~m}$ deep is over-saturated (200 $280 \%$ ), and the bottom layer even in the shallow pond of $2 \mathrm{~m}$ deep is deficient in $\mathrm{O}_{2}$.

In autumn we often see gasping of fish on the surface of an eutrophic pond, being often found in the morning. It is probably due to the fact that the consumption of $\mathrm{O}_{2}$ by phytoplankton and the circulation of water caused by lowering of temperature at night have brought up the non-oxygen bottom water. In some 'tameike' ponds a high temperature reaches to the very bottom layer in the summer stagnation period, so that fish often perish as a result of an abrupt circulation of water due to the sudden fall of water temperature at the surface. In the cases like this, $\mathrm{O}_{2}$ was observed to be nil from surface to bottom, the water showing a blackish colour and the bottom mud giving out a repulsive odour peculiar to foul water. The effect of $\mathrm{H}_{2} \mathrm{~S}$, therefore, was highly probable. In lakes of much deeper water, the difference in temperature between surface and bottom is so great that, as pointed out before, the circulation of water hardly occurs partially. The circulation of water in a 'tame ike' pond occurs from surface to bottom due to the slight fall of water temperature. This is especially to keep guard against fish-breeding ponds.

\section{f) Artificially Modified Conditions and Plankton Communities}

Artificially modified conditions may be divided into two parts; the first is the 
contamination by an inflow of domestic sewage, the polluted water from manufactory, and the fertilization in fish culture ponds; and the other is the drying-up of pond water by the artificial regulation.

Artificial Contaminction: Remarkable contamination is to be seen in ponds with an inflow of sewage from the neighbouring dwelling houses or animal-sheds, and also in fishbreeding ponds which are fertilized. The $\mathrm{pH}$ value in such ponds are, in most cases, alkaline throughout the year and are in plenty, not only $\mathrm{Cl}^{-}$and $\mathrm{SO}={ }_{4}$ but nutritive salts, with the result of leading to the abundant production of plankton. From summer through autumn, blue-green algae such as Microcystis and Anabaenc, and green algae such as Scenedesmus and Acanthosphaera greatly proliferate, forming "water-bloom".

The ponds with an inflow of polluted water from the neighbouring factories are disharmonious, in spite of the presence of rich nutritive salts, the existence of organisms being highly limited or made impossible. The degree of contamination, however, varies according to the kinds of factories (manufacturing medicine, steel wires, pulp and others, from which polluted water flows in). Accordingly, the states of natural or artificial 'tame-ike' ponds proceed from oligotrophy to eutrophy, and further to polytrophic and disharmonious type by the inflow of polluted water. And this gives rise to the formation of plankton communities peculiar to each 'tame-ike' pond.

Drying due to Drainage and the Adaptability of Plankton: The characters of 'tame-ike' ponds already discussed in connection with plankton organisms are also shared in common by natural ponds. The most important factor distinguishing 'tame-ike' pond from natural pond is the fact that in the former the water volume can be regulated artificially and can be completely drained and dried up in extreme cases. In the preceding chapter, the writer stated that plankton communities could recover in a pond dried up for half a year, soon after the pond was filled with water again, and that many planktonic organisms appeared from dried bottom mud in the laboratory condition. But the recovering rate of plankton was very low, when extremely dried mud was used. Even after they are completely drained, 'tame-ike' ponds may generally preserve some degree of moisture, making it possible for planktonic organisms to maintain their lives. There arises a question as to how far these planktonic organisms are adaptable to this sort of dryness.

SHELFORd (1913) and WELCH (1935), who were interested with the life peculiar to temporary ponds, pointed out that, although both Eubranchia and Cyclops finished their life history in a short time, their eggs could survive dried-up mud for many months. Cyclops is also a principal constituent member of plankton in Japan not only in temporary ponds but also both in 'tame-ike' ponds and in permanent ponds. From the planktonic fluctuations in 'tame-ike' ponds, Cyclops is a perennial species which repeats its short life cycle. Its eggs, nauplii and adults are always found in these ponds throughout the year, and therefore, at whatever time the ponds may be dried up, it is a species hardy enough to survive there. 
Daphnia pulex produces resting eggs early in spring, and they are capable of being hatched in an extreme dryness. After such a dryness lasts several months, they have hardly the ability to hatch out. The resting eggs are produced once or twice a year, so that when drying-up occurs before they are produced, Daphnia pulex may be more disadvantageous than Cyclops. If, however, even one of the resting eggs can survive such drying-up and can hatch out, it increases enormously by means of parthenogenesis. In this respect, Daphnic pulex has, no doubt, an advantage over Cyclops. The rotifers could also reappear out of the dried-up bottom mud. It may, therefore, be considered that the rotifers can survive the dried-up mud for a fairly long time, if the mud contains moisture to a certain extent.

The phytoplanktonts seem also to be dormant in various resting stages, such as the dormant spores of Anabaena, the zygotes of Spirogyra, Ulothrix, Mougeotia and Oedogonium, and the resting spores of diatoms. The decreased tendency towards phytoplanktonic reappearance in Tsujiga-ike pond after it was dried up may be due to the season when the drying up occurred. Pinnularia and other diatoms, though they had not been confirmed to be alive or not in newly collected bottom mud, showed with in a few days the filling of yellowish green protoplasm in their cells and began to move. Some species of diatoms may be tolerable to the drying-up, even when their resting spores are not formed.

From the viewpoint of drying-up, 'tame-ike' ponds as an environment hold a position just between permanent ponds (or lakes) and temporary ponds. It will be necessary to make detailed comparative studies of plankton communities in these three kinds of bodies of water to make clear the adaptability of plankton to the drying-up of 'tame-ike' ponds. Each planktonic species have also to be thoroughly investigated regarding its life history, its adaptability and durability against drying-up. Aside from the drying in their habitats, the dryness which ozcurs incidentally in the dispersal of minute organisms is of an important matter of study. This is an interesting subject to be left for future study.

\section{TYPOLOGY OF 'TAME-IKE' PONDS}

Although different in many ways, a 'tame-ike' pond and a lake have so many characters in common that it is hard to draw a line of demarcation between the two. It is natural, therefore, that types of ponds should partly correspond to those of lakes in many cases. Even so, at the same time 'tame-ike' ponds can be classified quite differently from large and deep lakes, not only because of their smaller water volume and speedier tempo of natural eutrophication but also because of both the sedimentation of organic matter due to the vast production of organisms and the inflow of domestic and industrial polluted waters. In this regard, ponds have a character of 'Saprobiensystem' sensu KoLKwITz \& MaRsson (1908). In the classification of ponds, therefore, some systems which combine both the trophic system of lakes and the saprobic system of rivers will have to be considered. 


\section{a) Pond Typss Based on the Chemical Substances}

The quality of pond water may be the synthetic outcome of all the conditions of ponds. As regards the classification of ponds based upon the quality of water, it will be useful matter to be concerned, i. e. various $\mathrm{H}_{2} \mathrm{~S}$ content, $\mathrm{NH}_{3}$ content, the change of $\mathrm{pH}$ value, the circulation of water, and the diurnal fluctuation of dissolved oxygen. Each of them indicates an aspect of the characters of pond water and has its own significance. However, so far as the metabolism in a pond is concerned, it may perhaps be necessary to make an analysis of both the nutritive salts indispensable to organisms and the dissolved substances acting inhibitory upon them. Yoshimura (1933) classified the Japanese lakes on the basis of the dissolved substances in water, setting forth their standard values in this connection. Kolwwitz (1935) compared the trophic stages of lakes with the saprobic stages of rivers. His method of classification is however based on a unitary system of rivers. In 'tame-ike' ponds, the process of trophic progress is dual. In other words, this means the combination of the oligo-eutrophic stage successions and all the harmonic-disharmonious conditions, and each 'tame-ike' pond may be placed between the two axes of these co-ordinates. Such harmonic and disharmonious types respectively can be further divided into two systems, autochthonous and allochthonous. In actual ponds, however, the characters of both systems and each type are found in many cases to overlap each other, each stage having a certain continuity.

In the autochthonous system of harmonic types, the shift from 1 to 2 is usually observed and further, that from 2 to the next eutrophic stage is theoretically possible. But this is made impossible due to the contamination resulting from the inflow of sewage or fertilization, the actual shift occurring between 3 and 4 as in the allochthonous system. In the disharmonious types, the stage successions $5 \sim 6 \sim 7$ can all be found; 5 is due to humus in the cold districts, and in most cases, may be found coincident with 8 which is made strongly acid by an organic acids given out from peaty materials.

Yoshimura has pointed out that his dystrophic phase of disharmonious types is not always oligotrophic, it containing a fairly large amount of phosphate and nitrate in many cases. The dystrophic phase gradually becomes eutrophy in warmer districts, losing its strong acidity and assuming a character of weak acidity or neutrality. The 7 , which originally belongs to the eutrophic type in warmer temperate districts, shows the same characteristics as the ponds in the frigid districts, since so much organic matters are deposited due to the overproduction of organisms that their deposition outrun the rate of decomposition. However, weak acidity or neutrality is mostly observed in this type of ponds. 'Tame-ike' ponds rich in Fe-ion are found among those belonging to oligo-, mesoand eutrophic type respectively. Those rich in $\mathrm{Ca}$-ion are limited in number at present, being situated on the coral islands belonging to the Ryûkyû Islands, but such ponds will possibly be discovered in the areas of limestone formation in the 


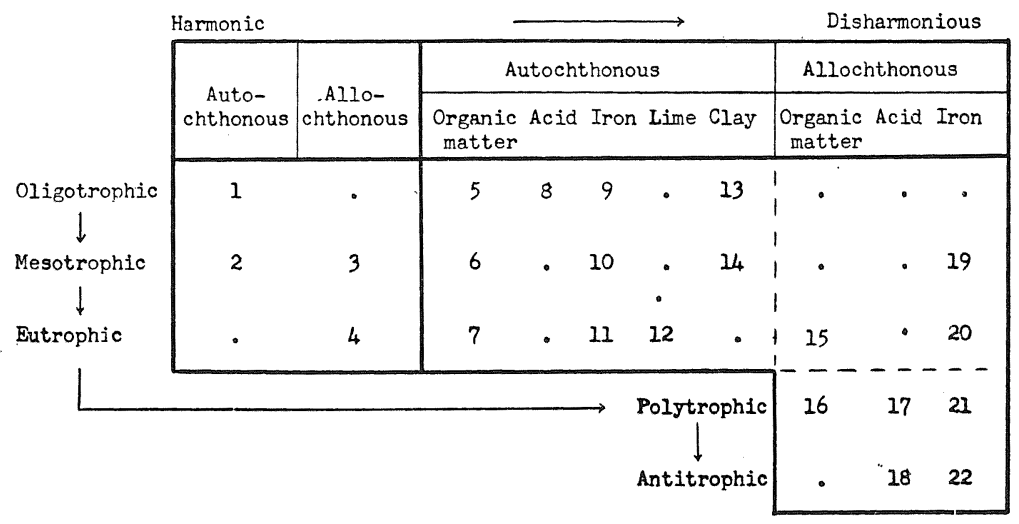

Fig. 30. Classification of 'tame-ike' ponds by the chemical conditions.

Each number on the system indicates the positions of the investigated ponds.

future. Those of intense turbidity due to clay lie either in the rocky mountains or on the tablelands composed of diluvial clayey formation, but not among eutrophic ponds. The allochthonous system consists of the water of extremely abnormal quality derived from the industrial pollution. When such a contamination is slight, the phase 4 of a harmonic type is possible, but as the contamination becomes intensified, the well-being of plankton is handicapped till a polytrophic phase is reached at last. The 16,18 and 21 , as shown on the table, are of this phase, although planktonic organisms are still found in small numbers. When the contamination becomes extreme, the $\mathrm{pH}$ value decreases to 3.0 as in pond No. 1 at Tsuchiyama, probably due to inorganic acid. Such a body of water is said to be an antitrophic phase which makes it impossible for planktonic organisms to exist. To this phase belongs 19 , it combines all the abnormal characters due to acid, iron and others.

\section{b) Pond Types Based on the Indicator Species}

Starting from the afore-mentioned quality of water, the writer tried to classify 'tame-ike' ponds based on the components and quantity of plankton inhabited them. Such a kind of classification has seldom been attempted by biologists in Japan except by Mrxadr's (1937) investigations of the bottom fauna in lakes. In Europe and America, lake typology has long been attempted based on the indicator or dominant sfecies of limnoplankton. In recent years, Thummark (1945), Hutchinson (1949), NygaARd (1949), JÄrnefelt (1952), RaWson (1956) and others have published their studies in this connection. On the other hand, KoLKwITz and Marsson (1908), Wilheimi (1914), Kolkwitz (1935), NygaARd (1949), LiebManN 
Table 27. A comparison of the trophic stages of lakes with the saprobic stages of rivers. (after Kolkwitz 1935)

\begin{tabular}{l|l}
\hline \multicolumn{1}{c|}{ Saprobie-Stufe } & Trophie-Stufe \\
\hline Katharob (eigentrich keine Saprobie-Stufe) & oligotroph \\
Oligosaprob & oligotroph \\
$\alpha$-mesosaprob & eutroph \\
$\beta$-mesosaprob & eutroph \\
Polysaprob & polytroph \\
Polysaprob (Faulflüssigkeit) & polytroph \\
verschieden (Wasser mit Giften) & antitroph \\
\hline
\end{tabular}

(1958) and TSUDA (1959) have dealt with plankton as important indicators useful to the saprobic system of rivers.

There is, however, much difficulty in determining plankton indicators. In the first place, species and dominants among the plankton vary according to the season of their occurrence. In the second place, most of the dominant or representative species do not serve our purpose as indicators due to their extensive adaptability to various environmental conditions. Moreover, there is a tendency that those which may safely be chosen as indicator species do not always appear in other ponds of the same water quality. In the third place, it is fairly possible to distinguish one pond from another in an extreme phase of their water quality, but is not seldom very difficult, when the water quality is in its intermediate or transitional phase.

There are, however, advantages in connection with indicator species, if they are successfully chosen. Firstly, the fact that a fixed indicator species of plankton can be found shows the synthetic result of the environmental conditions of a pond inclusive of all the changes, spatial and temporal, and can serve as a more reliable clue to the true environmental understanding of it than the water quality which at best shows us only a temporary environmental phase of it. Secondly, unlike a lake, a 'tame-ike', as a whole, is uniform in its environmental condition. This ensures us many advantages, if only such indicator species can be correctly discovered.

In his reports of the pond groups on the coastal areas of the Inland Sea, the writer $(1957,1958)$ dealt with the relationship between the analytical results of pond water and the dominant planktonic organisms in it, thereby revealing the facts that most of species had a very extensive range of existence and that very few of the dominant species in harmonic ponds could be chosen as indicator species. In order to make up for this defect, he applied NYGAARD'S "compound index" to these pond groups in Chapter 2, Section 2, of the present paper and expounded its appropriateness. As stated before, however, this "compound index" is inapplicable to disharmonious ponds in general, because there are found only very few 
planktonic species. Accordingly, in attempting to make the typological classification of 'tame-ike' ponds, it is necessary to select indicator species by all means. By making a comparative study of both the results of chemical analyses and the planktonic organisms found in each pond, indicator species were therefore sought so that they might serve our purpose to decide the type of each pond from a nutritive viewpoint. The results obtained from this study are described below.

Phytoplankton: Staurastrum, Micrasterias, Cosmarium, Xanthidium, Arthrodesmus, Pleurotaenium, Desmidium and others belonging to desmids are found mostly in acid waters, which have only poor dissolved substances. Desmidium Aptogonum, Pleurotaenium Ehrenbergi, Hyalotheca dissiliens, Staurastrum gracile, St. paradoxum, St. tohopecaligense and Closterium seem to have a somewhat wider range of existence than the others, and are found in both oligotrophic and mesotrophic ponds. The other Chlorophyta, namely, Ankistrodesmus, Scenedesmus, Actinastrum, Tetraedron and Acanthosphaera are found abundantly in the ponds of advanced eutrophy. In Myxophyta, Microcystis aeruginosa, M. fios-aquae, Anabaena flos-aquae, Lyngbya sp., Chroococcus sp., Spirulina sp., Nostoc sp. and Merismopedia sp. are indicator species with an inclination for alkaline waters and are also found plentifully in the ponds of advanced eutrophy, and in particular Microcystis and Anabaena often form "water-bloom". Melosira granulata, Synedra ulna, Stauroneis produncta, Gomphonema acuminatum, Cymbella trugida, Cymbella affinis, Rhopalodia gibba, Surirella elegans and Pinnularia gibba, all belonging to diatoms, occur in abundance in flatland ponds. Although they may be representative planktonic species in eutrophic ponds, they tend to have so fairly wide range of existence that it may be advisable to avoid choosing them as indicator species.

Zooplankton: Phytoplanktonic species have so far been chiefly employed as indicator species. This is probably because phytoplanktonic species are more distinctly related with the results of chemical analyses of pond water, as compared with zooplankton. But if well chosen, some of the zooplankton can fully answer our purpose and serve as indicator species. Thummark (1945), JÄrnefelt (1952) and Rawson (1956), choosing the following few zooplanktonic species, employed them as indicator species. Oligotrophic ponds, -Bosmina longispina, B. obtusirostis and Diaptomus graciits; Eutrophic ponds, -Daphna cucullata, Bosmina longirostris, Keratella quadrata and Asp!anchna priodontc. Some of these are common species in Japanese ponds but as yet others have not been found in them. Roughly speaking, zooplanktonic species usually found in 'tame-ike' ponds are as follows.

Keratella and Asplanchna chosen by JÄrnefelt and RAWson as the indicator species of eutrophic lakes are found extensively and on that account, their choice is not considered appropriate. Species belonging to Brachionus, Filinia longiseta, Pedalia mira, Po'yarthra trigla, Euch'anis dilatata, Mytilina sp. and others, all of which are generally said to occur in contaminated pond water and actually have also a strong tendency to appear abundantly in eutrophic ponds, are found at the same time, though not plentifully, in mesotrophic ponds on tablelands and 
Plankton indicators (I)

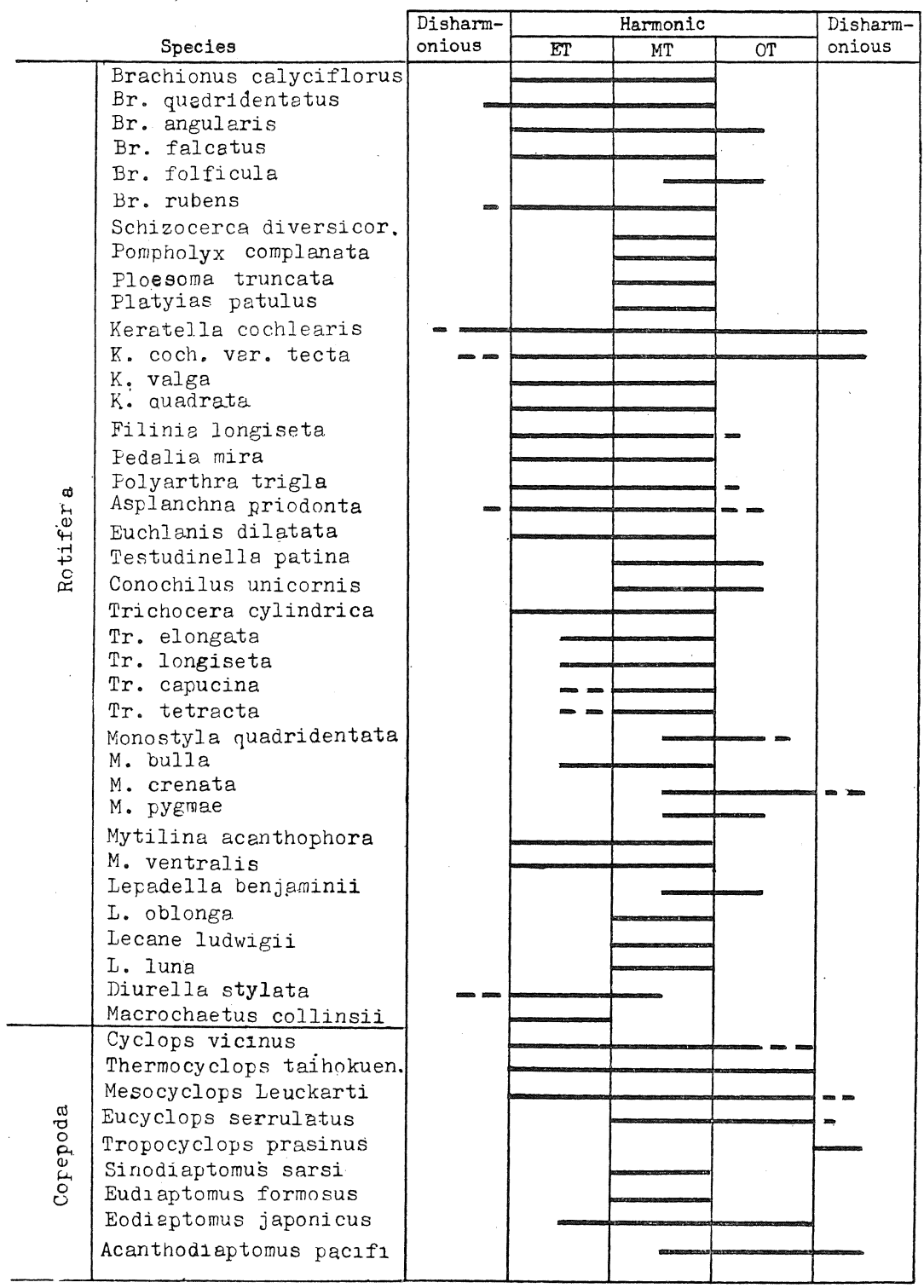

Fig. 31. Plankton indicators of 'tame-ike' ponds (1). 


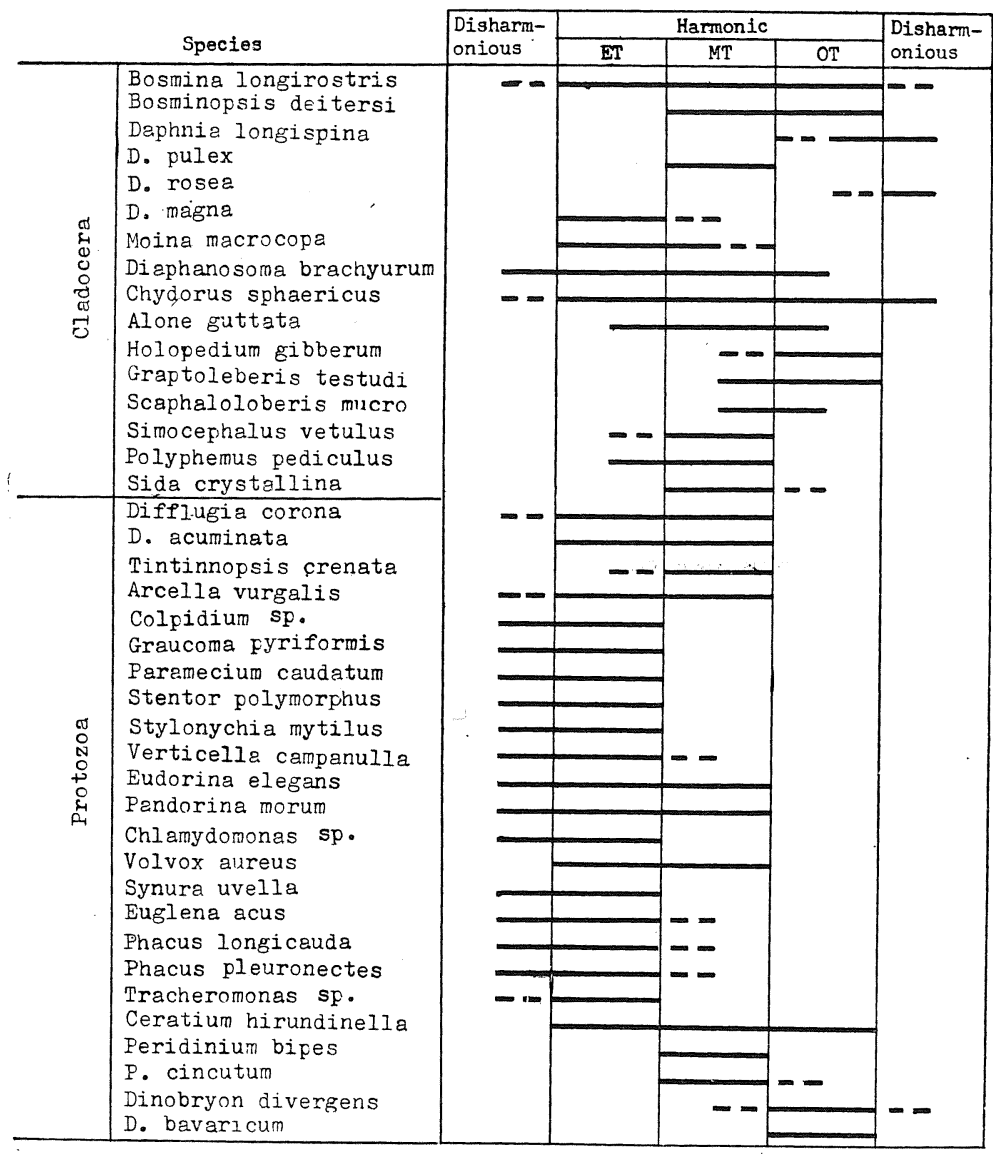

Fig. 32. Plankton indicators of 'tame-ike' ponds (2).

even in oligotrophic ponds on granitic formations, thereby revealing their fairly wide range of existence. What is more interesting to note in this regard is that Schizocerca diversicornis, Pompholyx compianata, Ploesoma truncatum, Platyias patulus, Trichocerca sp. and Lecane sp. indicate a rather limited distribution, appearing only in mesotrophic ponds, while, on the other hand, Brachionus for ficula, Conochilus unicornis, Monostyla quadridentata, M. crenata, Lepadella benjamini and others tend to show themselves in mesotrophic to oligotrophic ponds. 
Plenkton indicators (3)

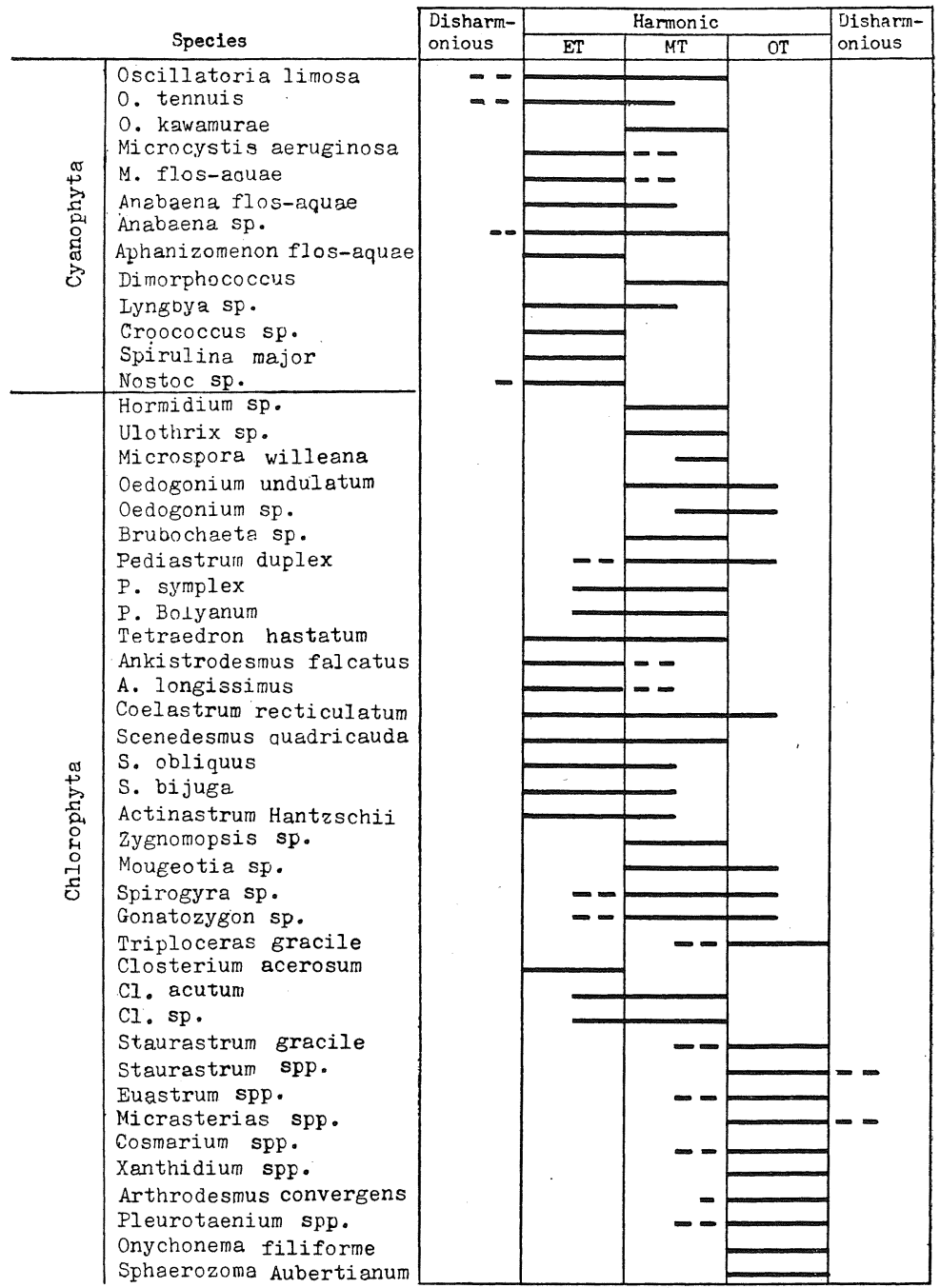

Fig. 33. Plankton indicators of 'tame-ike' ponds (3).

Species belonging to Copepoda are almost always found as predominant species: in ponds of any type but little or no significance can be attached to them, as their range of existence is very wide. It seems, however, that Acanthodiaptomus 
Plankton indicators (4)

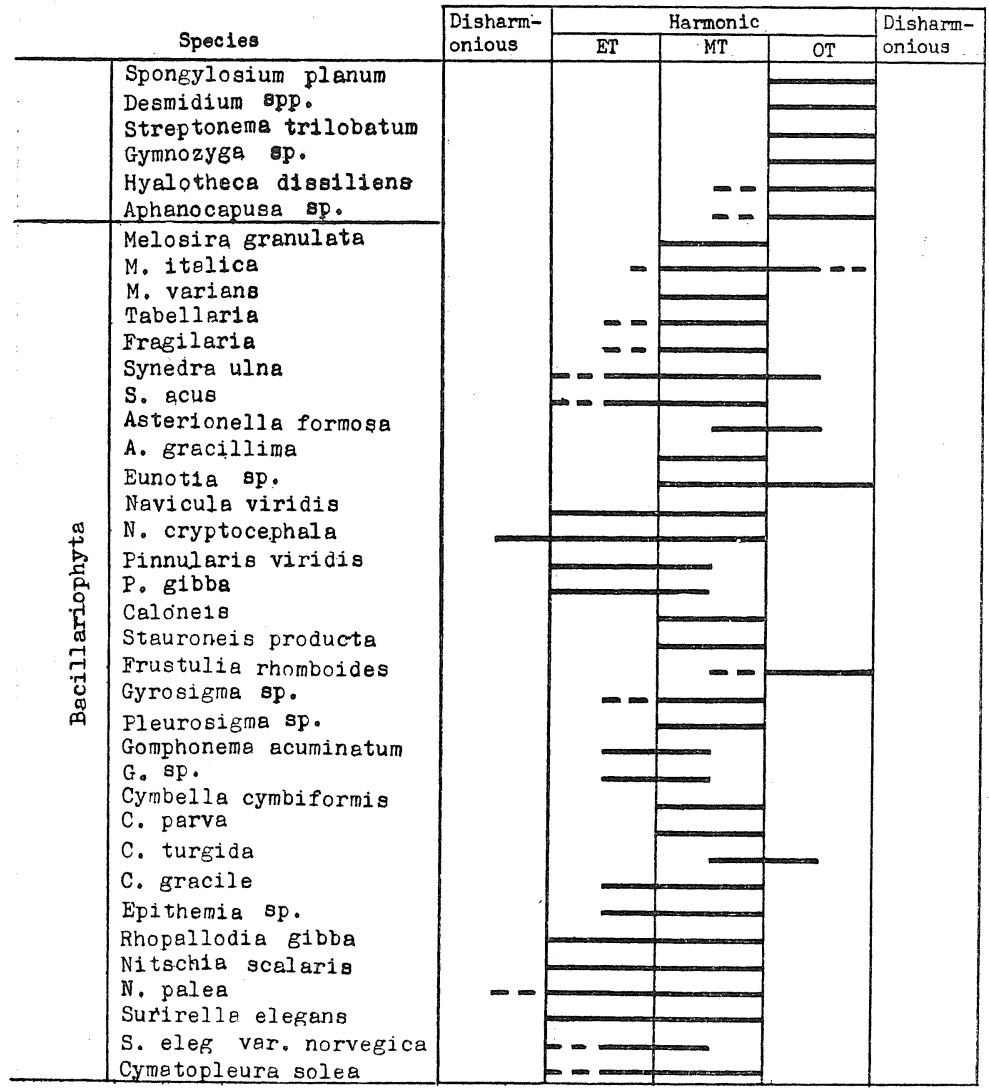

Fig. 34. Plankton indicators of 'tame-ike' ponds (4).

pacificus is found abundantly in ponds in which contamination is not so advanced.

Some species belonging to Cladocera, as stated before, are often adopted as indicator species. The indicators to eutrophic waters are: Daphnia pulex, $D$. magna, Moina macrocopa, Simocephalus vetulus and others, while Bosminopsis deitersi, Daphnia longispina, Scapholeberis mucronato and Ho'opedium gibberum are said to have an inclination for oligotrophic waters. Bosmina longirostris, Diaphanosoma brachyurum, Chydorus sphaericus and Alona guttata, all of which are generally said to inhabit eutrophic waters, are found in oligotrophic ponds in considerable frequency. It is probably more correct to regard them as having a fairly extensive adaptability, so that they have little use in being chosen as indi- 
cator species.

Some species of Ciliata (Protozoa) are of use as indicators of polytrophic or disharmonious saprobic ponds. Many polysaprobic species of Ciliata in the polluted rivers are also found in the bottom mud of eutrophic ponds. In Flagellata, Eudorina, Pandorina, Volvox, Chlamydomonas, Synura, Euglena, Phacus and Trachelomonas are found in the alkaline eutrophic waters, while Dinobryon divergens, $D$. bavaricum and $D$. cylindricum are in the oligotrophic waters of low acidity, and may be useful as indicator species chiefly in uncontaminated ponds in mountainous localities or on tablelands. Ceratium hirundinella, often found abundantly in eutrophic ponds, are dominant in most of the ponds. It is, however, inappropriate to choose them as indicator species, as they seem to have a very wide range of existence.

Figs. 31 34 show the five types of ponds based on the results of chemical analyses and along with them the existence ranges of principal planktonic species. The disharmonious ponds, however, are here classified merely into two types, eutrophic and oligotrphic, without making any further subdivision based on dissolved substances.

\section{c) Synthetic Types and the Systems of 'Tame-ike' Ponds}

The classification of 'tame-ike' ponds based on the results of chemical analyses and the choice of planktonic indicator species were described above without regard to the amount of planktonic production. As in the case of lake types, the system based on the synthetic results both of water quality and of planktonic species as well as the amount of plankton must be considered before distinctive types of 'tame-ike' ponds are established.

As for planktonic species, each 'tame-ike' pond has some representative species of its own due to its dissolved chemical substances, but it does not always follow that these species alone constitute the plankton communities of the pond. Even in disharmonious ponds, common species can be found in most cases. For instance, Bosmina longirostris, Daphnia longispina hyalina, Acanthodiaptomus pacificus, Eucyclops serrulatus and Keratella cochlearis, belonging to zooplankton, and desmids belonging to phytoplankton are found in dystrophic ponds in the cold northern districts. On the other hand, in ponds lying in the warmer districts and having plenty of peaty materials, there appear Chydorus sphaericus, Keratella cochlearis, Asplanchna priodonta and many other diatoms. Even in Kanai-jûkô pond uncommonly rich in $\mathrm{Fe}^{++}$, Brachionus rubens and Navicula cryptocephala are abundant, and in the saprobic Tanabe-Seiyaku pond, zooplanktonic species such as Brachionus angu!aris, Thermocyclops sp. and Bosmina longirostris, and phytoplanktonic species such as Trache'omonas sp., Euglena viridis, Microspora sp. and Pediastrum biwae are discovered, though the number of individuals of each species is very small. There seem to be two instances in this connection. In one instance, the number of planktonic species is small but two or three of those species are very plentiful. In the other instance, their number is pretty large, but they are found only scantily 

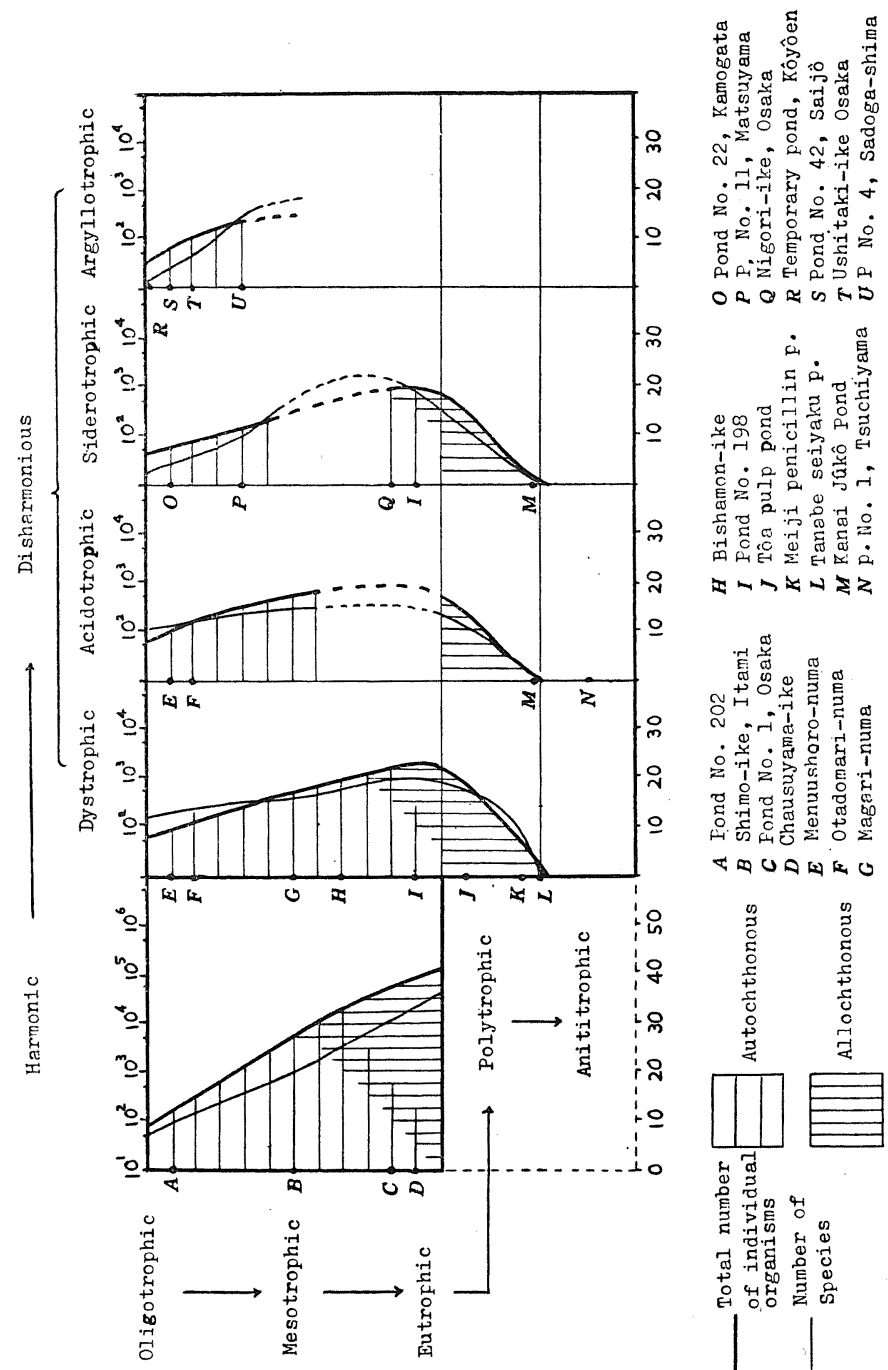

OROTUR土

is

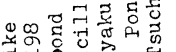

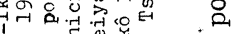

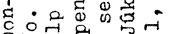

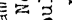

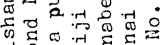

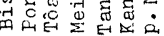

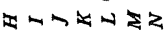

कृ

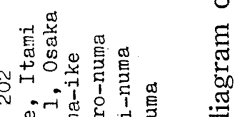

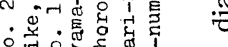

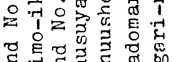

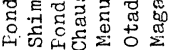

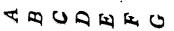

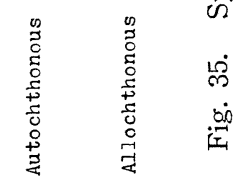

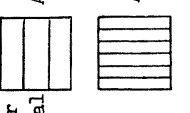

กั สูม

实是告

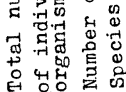

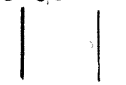

without exception. In antitrophic ponds, as in pond No. 1 at Tsuchiyama, Hyôgo pref., the existence of plankton is hardly possible. From the amount of planktonic production as shown above, it gradually increases in ponds according to the change from oligotrophy to eutrophy, as already pointed out by the results of quantitative 
analyses. In shifting from the harmonic type to the disharmonious one, planktonic species become limited qualitatively, but they are sometimes quantitatively plentiful and are scanty at the others. In antitrophic ponds, plankton is quite or nearly impossible to exist. The principal planktonic indicator species, the number of planktonic species and their production (represented by the number of individuals) are synthetically charted on the basis of the results of chemical analyses (Fig. 35).

\section{CONCLUSION}

The writer has so far dealt with 'tame-ike' ponds from the ecological viewpoint in the interrelation between the results of the analysis of their environmental factors and the composition of plankton communities. The data stated already will be taken up again here, and by putting them in order, the characteristics of 'tame-ike' ponds will be discussed in distinguishing them from the other forms of water bodies.

The distribution of 'tame-ike' ponds, as compared with that of natural ponds, is rather limited, because they are constructed for human requirement, especially to serve the purpose of irrigating paddy fields. Yet, they are found pretty extensively all over the country, being distributed chiefly in the alluvial low-lying areas or on the diluvial tablelands. The investigations of the pond groups on the different geological formations in the suburbs of Osaka show little difference regarding their water quality. When such a comparative study is extended to all the pond groups scattered in Japan, distinctive regional characters are noticed in them. The islands on the Japan Sea are visited by monsoons in winter, and the islands on the Pacific are exposed to the onset of typhoons. In all these islands and coastal areas, 'tame-ike' ponds were under the direct influence of the sea. The writer's data showed that, although the $\mathrm{Cl}^{-}$content was larger by sea-breezes, they still remained within the confines of freshwater ponds.

Besides these natural restrictive conditions, the artificial contamination due to domestic sewage, polluted water from industrial factories and to fertilization is an important factor which affects 'tame-ike' ponds. Natural eutrophication, therefore, is often united with the secondary eutrophication due to contamination, and in extreme cases, there are saprobic ponds of similar nature to the polluted rivers flowing through large industrial cities. Some of such ponds are filled with water of an entirely abnormal kind and come under the head of disharmonious ponds. From the viewpoint of chemical analysis, therefore, 'tame-ike' ponds may be classified into no less numerous or even more numerous types than lakes.

In their vertical and temporal fluctuations of various factors, 'tame-ike' ponds are characterized quite differently from lakes. Their water temperature has a gradient from the surface to the bottom but it has no thermocline. The temperature is more than $25^{\circ} \mathrm{C}$ even in the bottom water in summer and goes down to around $5^{\circ} \mathrm{C}$ in winter. When an abrupt lowering of surface water temperature takes place 
sometimes in summer, water completely circulates as in the autumnal circulation. Both the $\mathrm{pH}$ value and the dissolved substances vary according to the conditions of ponds. Oligotrophic ponds are weak acid from the surface down to the bottom, the dissolved $\mathrm{O}_{2}$ never reaching its saturation point all day long. In eutrophic ponds; however, the $\mathrm{pH}$ value ranges from 9.8 at the surface layer to 7.2 at the bottom layer; the dissolved $\mathrm{O}_{2}$ is supersaturated at the surface layer but becomes nil beneath the middle layer. Between these two types of ponds, mesotrophic ponds hold their position, showing intermediate values in all respects. According to the observations of seasonal fluctuations, it is found that one pond repeated nearly the same cycle fo: four years and remained fairly stable. In 1956, Hydrilla verticillata floated up and decomposed, so that the water became an extraordinary contamination, which influenced upon the pond for half a year until it was quite recovered to normal condition.

The characters of 'tame-ike' ponds, as stated above regarding their water quality, may be due to the morphology of their water-basin. Unlike lakes, they are so limited both in area and depth, that their water volume is much smaller likewise. This is why they are easily subject to various influences by natural environmental factor and artificial contamination.

Needless to say, planktonic organisms come under the influences of these physical and chemical conditions of pond-water. For instance, there is a tendency that while many desmid species, together with Holopedium gibberum, appear in pond groups of smaller $\mathrm{Ca}$-ion content, more zooplanktonic species and fewer phytoplanktonic species are found in ponds of clayey turbidity. Oligotrophic ponds are populated chiefly by desmids, Dinobryon, Daphnia longispina, Melosira italica; eutrophic ponds are inhabited not only by Microcystis aeruginosa, Anabaena flosaquae, Scenedesmus sp., Ankistrodesmus falcatus, Daphnia pulex, Moina macrocopa. Brachionus calyciflorus, Asplanchna priodonta and others, but by Eudorina elegans, Pandorina morum and Volvox aureus, and saprobic ponds by species belonging to Flagellata and Ciliata, such as Euglena and Vorticella, and certain creeping rotifers. It stands also quite to reason from the viewpoint of climatic conditions that northern or cold-water planktonic species should be found in ponds in the cold northern districts, while southern or high temperature tolerable species show themselves in ponds in the subtropical districts. However, it is noticeable in this connection that there are found those northern species in winter and those southern species in summer in 'tame-ike' ponds lying in Central Japan. Viewed through the year, therefore, 'tame-ike' ponds in warmer districts are rich in planktonic species. As stated before, this phenomenon may be chiefly due to the water temperature of 'tame-ike' ponds, which are generally shallow and are easily changeable in conditions. Such environmental conditions make both northern and southern species to establish their life in the ponds possible.

It is well-known that, in the cold northern districts, ponds usually become dystrophic due to low water temperature. But it often happens that even eutrophic ponds in warmer districts are turned into dystrophic because the over-production 
of organisms, by which the amount of deposition exceeds the rate of their decomposition. In eutrophic ponds, the proliferation often gives rise to remarkable changes in the $\mathrm{pH}$ value and the amount of dissolved substances. All these findings show that organisms, too, are the causatives which affect the environment and water quality of 'tame-ike' ponds.

Concerning the drainage and its subsequent drying-up of a 'tame-ike' pond, it is noteworthy that, even after the drying-up for half a year, most of organisms appeared alive again when it was refilled with water. On the whole, zooplanktonic species tend to show a larger rate of revival than phytoplanktonic species. It was expected in experiments that the plankton fauna and flora, when the bottom mud was dried up excessively, would result in a fairly remarkable change, but almost every species was found to adapt itself to the drying-up and survive it, when it occurred in the natural environment of a pond. This was ascertained by experiments and observations with regard to several planktonic species.

From the above-stated, it is found that 'tame-ike' ponds, which can be classified in complex phases, are characterized by the two types, the trophic system of lakes and the saprobic system of rivers flowing through large cities. It is possible therefore to consolidate them by the two axes of co-ordinates, i. e., oligotrophic $\rightarrow$ eutrophic, and harmonic $\rightarrow$ disharmonious, including the results of chemical analyses as well as the number and quantity of plankton.

Furthermore, there still remains much to be studied in relation to $\mathrm{Ca}^{++}, \mathrm{Fe}^{++}$, clayey turbidity, the interrelationship between the kinds and adaptability of planktonic organisms to the drying-up of 'tame-ike' ponds. In considering those ponds whose ecosystem is still open to question, inquiry must be made into the process of the circultion of energy.

\section{SUMMARY}

1. Ponds, as lakes and rivers, are one of the important inland water. In Japan where rice-culture is carried on extensively, there is a wide distribution of man-made 'tame-ike' ponds in addition to natural ones. Unlike lakes, they are small both in area and in depth, and besides being easily subject to the influences of environmental conditions, they have a distinctive character of their watervolume which is able to be regulated artificially. The studies of such 'tame-ike' ponds have so far been rather neglected, and many problems still remain unsettled about them, and in particular as the basis of utilizing for pisciculture. The present paper aims at the analytical study of their environmental factors, the elucidation of the relationship between such factors and plankton communities, with which the writer tried to make clear the organic production and metabolism in such a kind of ponds.

2. From the above-stated viewpoints, an attempt was made, (1) to make comparative studies extensively, (2) to perform detailed observations of representa- 
tive 'tame-ike' ponds in regard to their physical and chemical factors, as well as diurnal and seasonal fluctuations of plankton communities. With the three dimensional aspect obtained from the vertical distribution of temperature, $\mathrm{pH}, \mathrm{O}_{2}$, \&c., and the recovery of planktonic organisms from the drying-up subsequent to drainage, the writer has made an endeavour to reveal the characters of 'tame-ike' ponds.

3. In making compartive studies, the pond groups on different geological formations were taken up in the suburbs of Osaka. Aside from the alluvium, geological formations had little effect with the difference from one pond to another. A fairly remarkable difference due to artificial contamination among the pond groups on the diluvium was detected in the water quality, and in the number and quantity of planktonic species.

4. The coastal areas of the Inland Sea have a dense distribution of 'tame-ike' ponds hardly seen elsewhere in Japan. As a result of comparative studies of representative ponds in such prefectures as Osaka, Hyôgo, Okayama, Kagawa and Ehime, natural eutrophication was usually found in a more advanced stage with inland 'tame-ike' ponds. Those 'tame-ike' pond groups lying near the seashore exposed to either monsoons or typhoons have a larger $\mathrm{Cl}^{-}$content. On the Islands of Sadoga-shima and Okino-shima, where there comes a strong monsoon from the continent, the pond groups on the western coast have a larger $\mathrm{Cl}^{-}$content than those on the eastern coast, which shows the effects of sea-breezes undoubtedly. The $\mathrm{Cl}^{-}$content, however, is seldom found to exceed $100 \mathrm{mg} / \mathrm{l}$ and the ponds remain within the confines of freshwater ones, so that the plankton communities in them are composed of freshwater species. The same is not true only in those ponds which are invaded by seawater or which had at one time been connected with the sea.

5. In the coastal areas of the Japan Sea, the pond groups at the seaside of the Tottori sand dunes, or at Kisagata and Konoura beach, Akita pref., at Tsugaru, Aomori pref. are all exposed to the onset of strong monsoons in winter, so that, as a matter of course, they all have a larger $\mathrm{Cl}^{-}$content than any of inland 'tameike' ponds, but with $44 \mathrm{mg} / \mathrm{l}$ at Kidaka beach, Tottori pref. as its maximum, the rest of these pond groups shows smaller contents without exceptions. The 'tameike' ponds in Akita and Aomori prefectures are not so typical dystrophic as those in Hokkaido, but they have nevertheless a distinctive character of dystrophic ponds in the cold northern districts.

6. Of the pond groups in both the Yamagata and the Nara basins chosen as representative inland basins, the Shiratakayama pond group in the former showed free both from the effects of sea-breezes and from artificial contamination, being indicated as a progressive state of dystrophy. Misumi-ike which is a natural pond at Ôtori at about $1000 \mathrm{~m}$ above sea level, Yamagata pref. was a typical dystrophic pond, showing a close resemblance to shallow lakes in the districts of higher latitudes. The Nara basin, which is also shielded from the effects of sea-winds, has been a highly developed region in culture from the remote days, so that there is observed fairly advanced eutrophication in 'tame-ike' ponds. Especially the 
gold-fish ponds at Koriyama in the same basin are made extremely eutrophic due to the repeated fertilization.

7. Most of the pond groups in the suburbs of large cities are extremely contaminated. In those 'tame-ike' ponds with an inflow of sewage or rich in other organic matters due to fertilization, Microcystis, Anabaena, Scenedesmus and others were found forming "water-bloom" on the water surface. The ponds with an inflow of polluted water from industrial factories were contaminated variously, according to the kinds of their manufacturing processes. Some have water of black in colour, and gave out an offensive odour peculiar to excessively deteriorated water, while others show strong acidity and contain an extreme amount of $\mathrm{Fe}^{++}$which tinged the waterside reddish brown or an extreme saprobic nature of water. In all these ponds no planktonic organisms can be found, and if found, they are quite few in the number of species and in quantity as a result of the inhibitory action of the pond water.

8. The water quality, the vertical distribution of plankton and the diurnal fluctuations of temperature were studied in relation to some types of ponds, i. e. oligotrophic, eutrophic and intermedate. Each type of these ponds has a slight gradient of temperature from surface to bottom in summer, but there develops no thermocline. The diurnal fluctuations of temperature at the surface layer are more remarkable in ponds than in lakes.

In oligotrophic ponds the $\mathrm{pH}$ value remained slightly acid all day long, the vertical distribution of plankton showing little or no change at the same time. In eutrophic ponds the $\mathrm{pH}$ value ranged from 9.8 at the surface layer to 7.2 at the bottom layer, even when these ponds were only $2 \mathrm{~m}$ deep. Ponds of the intermediate type indicated the $\mathrm{pH} 8.5$ at the surface layer and the $\mathrm{pH} 6.4$ at the bottom layer, alkaline turning into acid.

As for the dissolved $\mathrm{O}_{2}$, it never reached its saturation point in oligotrophic ponds, although even the bottom layer contained $30 \sim 50 \%$ of it. In eutrophic ponds it remained in a state of over-saturation all day long, except at the bottom layer where it was utterly absent. The absence of $\mathrm{O}_{2}$ at the bottom layer occurred even when such ponds were only $2 \mathrm{~m}$ deep. In ponds of the intermediate type, all the numerical values obtained were just middling.

Some slight tendency was noted as to the vertical distribution of planktonic species and the shift of some species from one layer to another, but because of the shallowness of water, it was impossible to detect any distinctive features peculiar to these ponds.

9. The mesotrophic Shimo-ike pond at Itami, Hyôgo pref. was investigated for four years consecutively regarding its water quality and plankton communities. In June, 1956, Hydrilla verticillata growing at the bottom floated up in great numbers and decomposed. This led to a temporary disruption and confusion of plankton communities, although normal condition was restored before long. It may be considered, therefore, that unless there is an exceptionally remarkable external disaster, both water quality and plankton will remain stable. 
10. The drying-up due to artificial draining is one of the distinctive characters of 'tame-ike' ponds. The investigations were conducted in Tsujiga-ike pond at Ikeda Citly and Minamimonzen-ike (pond No. 2 in the northern part of Osaka), when they were left dried up for about six months.

In the former efforts were concentrated on the quantitative study of planktonic organisms both before and after the drying-up, and in the latter on the developing process of planktonic organisms from the bottom mud in the laboratory experiments.

11. The environmental conditions and factors of 'tame-ike' ponds and their inter-relationships were discussed. These were classified into two conditions, viz., natural and artificial, topographical, geological, climatic and temporal factors on one side, and contamination and drying-up on the other. The relation between the planktonic organisms and the individual factor included in each condition was examined. Above all things, climatic and artificial influences on the quality of pond water seem to be very great, but this is chiefly because 'tame-ike' ponds have a distinctive morphological character, viz., smallness of area and of depth. Furthermore, the fact has much to do with the component species of planktonic communities and their multiplication. In taking up the drying-up of 'tame-ike' ponds due to artificial drainage the adaptability of planktonic organisms to it was dealt with based on the field observations and the laboratory experiments.

12. 'Tame-ike' ponds are characterized by both the trophic system of lakes and the saprobic system of rivers receiving polluted waters. By consolidating the complex types of 'tame-ike' ponds which have the two different sides, an attempt is made to classify them in such a way that it will be considered appropriate both limnologically and practically. The selection of plankton indicators will probably be useful in judging the chemical quality of water in 'tame-ike' ponds.

\section{REFERENCES}

Ahustrom, E. H.: A revision of the rotatorian genera Brachionus and Platyias with descriptions of one new species and two new varieties. Bull. Amer. Mus. Nat. Hist., 77, 3, 143 184, 1940.

Atкins, W. R.G. \& G. T. Harris: Seasonal changes in the water and heleoplankton of freshwater ponds. Sci. Proc. R. Dublin Soc., 18, 1 21, 1924.

Bethat, H.: Beiträge zur Kenntnis des Teichplankton I. Ber. Dtsch. bot. Ges., $65,6,187 \sim 196,1952$.

- : Ibid. 66, 2, 93 100, 1953.

— Ibid. 68, 8, 319 330, 1955.

Cole, G. A.: Notes on Copepod encystment. Ecology, 34, 1, 208 211, 1953.

Dacksbach, N. K.: Über verschiedene Typenfolgen der Seen. Arch. Hydrobiol., 20, 65 80, 1929.

EjDy, S.: A study of freshwater plankton communities. Illinois Biol. Monogr., 
Univ. Illinois Bull., 12, 4, 1 93, 1934.

Edmondson, W.T., G. C. Anderson \& D. R. Paterson: Artificial eutrophication of Lake Washington. Limnol. and Oceanogr., 1, 1, 47 53, 1956.

Gorham, E.: The chemical composition of some western Irish freshwaters. Proc. R. Irish Ac., 58, 11, 237 243, 1957.

HADA, Y.: Studies on bog lakes, I. bog lake at Tokotan. Jap. J. Limnol., 6, 4, 143 151, 1936. (in Japanese).

: Ibid. Jap. J. Limnol., 7, 1, 13 30, 1937. (in Japanese).

HamaI, I. \& K. Osawa : Autumnal communities of the plankton of pond Oike in Toyohashi, Aiti Pref. with special reference to the population density of the surface stratum. Ecol. Rev., 13, 1, 47 56, 1951. (in Japanese).

HARRING, H. K. \& F. J. Myers: The rotifer fauna of Wisconsin. III IV. Trans. Wisconsin Ac. Sci., 22, 215 423, 1926.

Hata, K., K. Nakamura, E. Miyasaka \& S. Ina : Studies on the production of the 'tame-ike' ponds. I. The fundamental survey of the condition of the 'tame-ike' ponds. Freshwater Fish. Res. Lab. 1 118, 1949. (in Japanese).

Higashr, M.: Micrasterias from Japan. Jap. J. Limnol., 8, 3〜4, 428 33, 1938. (in Japanese).

Hirano, M. : On some so-called southern elements of Desmids in Kansai, middle Japan. Acta Phytotax. Geobot., 8, 1, 147 152, 1943. (in Japanese).

: Further note on some so-called southern Desmids from Kansai, middle Japan. Ibid., 14, 2, 49 52, 1950. (in Japanese).

: On the distribution of Desmids in Oze District. Jap. J. Limnol., 16, 1, 15 23, 1952. (in Japanese).

: The alpine Desmids from the Japanese Alps. 1, 2. Bot. Mag. (Tokyo), 66,779, 125 134; 780, 205 210, 1953.

: Flora Desmidiarum Japonicarum. Contr. Biol. Lab. Kyoto Univ., I, 1 57, 1955 ; II, 58 106, 1956 ; IV, 107 165, 1957 ; V, 166 225, 1957 ; VII, 226 301, 1959 ; IX, 302 386, 1959.

: The phytoplankton of some ponds in the western suburbs of the City of Yamagata. Jap. J. Limnol., 20, 4, 185 186, 1959. (in Japanese).

Hôgetsu, K. \& S. Ichimura : Studies on the biological production of Lake Suwa. VI. The ecological studies on the production of phytoplankton. Jap. J. Bot. 14, 2, 280 303, 1954.

HöLL, K. : Oekologie der Peridineen. Pflanzenforschung, 11, 1928.

HoRASAWA, I. : The water conditions and plankton in the outside moat of Imperial palace and Senshunen. Jap. J. Limnol., 2, 29 43, 1932. (in Japanese).

- : A preliminary report on the biological index of water pollution. Zool. Mag. (Tokyo), 54, 1, 37 38, 1942.

Huber-Pestalozzi, G. : Das Phytoplankton des Süsswassers. Binnengewässer (Stuttgart), 16, 2, 1941.

HuJita, S. : On the water investigation of productive power in the irrigation pool. Bull. Educ. Facul. Shizuoka Univ., 2, 87 90, 1952. (in Japanese). 
: On the effect of various kinds and combination of fertilizers on the reproduction of Daphnia longispina. Ibid., 5, 1 9, 1954. (in Japanese).

: Studies on the fertilization of fish culture pond. I II. Ibid., 9, 189 196, 1958. (in Japanese).

Hutchinson, G. E.: Limnological studies in Connecticut. VII. Critical examination of the supposed relationship between phytoplankton periodicity and chemical change in lake waters. Ecology, 25, 1, 3 26, 1944.

IoHImURA, S.: On the ecological meaning of transparency for the production of matter in phytoplankton community of lake. Bot. Mag. (Tokyo), 69, 815, $220 \sim 226,1956$

\& Y. ARUGA : Some characteristics of phytosynthesis of freshwater phytoplankton. Ibid., 71, 841, 261 269, 1958.

INABA, D.: The 'water-change' and plankton in eel-culture ponds. Shokusan Kaishi, 4, 9, 159 164, 1934. (in Japanese).

InaBA, T.: The preliminary study on the 'Mizukawari' in eel-culture ponds. Shizuoka Fac. Fish. Inst., Hamana-ko Branch, 39, 1937. (in Japanese).

Iто, T. \& T. IwaI : Studies on the 'Mizukawari' in eel-culture pond. I. Fac. Fish. Pref. Univ. Mie, 2, 1, 162 177, 1955 ; 2, 2, 317 346, 1956 ; 2, 3, $502 \sim 516,1957 ; 3,1,122 \sim 222,1958$. (in Japanese).

\& _ : Studies on the 'Mizukawari' in eel-culture ponds. XIV $\sim \mathrm{XV}$.

Jap. J. Limnol., 20, 2. 49 63. 1959. (in Japanese).

IWASAKI, K.: On the plum and mulberry field from the regional point of view of the agricultural landscape on the coast of Kii Peninsula. Bull. Otsuka Geogr. (Ôtuska Chirigaku Rombunshû). III. 159 193, 1934. (in Japanese).

IzU, N.: A degree of harm to the principal agricultural plants by the salt-breeze. J. Meteorol. Soc. Jap. (Kishô-shûshi), 32, 12, 496 504, 1913. (in Japanese).

JÄhnefelt, H. : Plankton als Indikator der Trophiegruppen der Seen. Ann. Ac. Sci. Fenn., Ser. A, IV., Biol. 18, 1〜29, 1952.

: Zooplankton und Humuswasser. Ibid. Ser. A. IV, Biol. 31, 1 14, 1956. : Über die vertikale Tage- und Nacht-Verteilung der Planktons im Lohjanjärvi. Hydrobiologia, 10, 175 197, 1958.

KANECHIKA, Y.: Fish culture in the ponds. Stud. Aqua. Prod. (Suisan Kenkiushi), 2, 49 60, 1931. (in Japanese).

$K_{\text {AWAMURA, }}$ J. : In the fauna and flora of a pond, Kagamiike of Tôdaiji-temple, Nara, especially on its plankton community. Jap. J. Ecol., 6, 4, 173 176, 1957. (in Japanese).

KaWANuRA, T.: Limnological investigations of the Tsugaru-jûniko Lake group, Aomori prefecture, Northern Japan with special refernce of the plankton communities. Mem. Fac. Fish. Hokkaido Univ., 4, 1, 1〜89, 1956.

KIKUCH, K.: A comparison of the diurnal migration of plankton in eight Japanese lakes. Mem. Coll. Sci. Kyoto Imp. Univ. Ser. B, 5, 1, 27 74, 1930.

KoIwaI, T. : The summer heleoplankton of twelve ponds in the suburb of City of Matsumoto. Jap. J. Limnol., 1O, 3 4, 171 180, 1940. (in Japanese). 
Kокuво, S. : Plankton of Japanese lakes. Recent Advances in Biology (Seibutsugaku-no-Shimpo), II, Tokyo, 1944. (in Japanese).

: Plankton Diatoms. Jap. Ass. Adv. Sci. (Nippon Gakujutsu Shinkô-kai), 1955. (in Japanese).

Kokubo, K. \& T. KaWAmuRA : Studies on the plankton of the lakes of Kamikita lake group. Jap. J. Limnol., 14, 2, 53 65, 1949. (in Japanese).

Kolkwirz, R. \& M. MARsson: Ökologie der Planzlichen Saprobien. Ber. Dtsch. bot. Ges., 26a, 505 519, 1908.

KoLKwiz, R. : Pflanzenphysiologie. Verlag Fischer, Jena, 1935. (Cited from Handbuch der. Frischwasser und Abwasserbiologie. Band I, by LteBirann).

KREUTNER, W. : Qualitative und Quantitative Untersuchungen von Plankton aus schlesische Versuchsteichen (Sulau) auf Grund dreijähriger Probeentnahme. Arch. Hydrobiol., 27, 1〜60, 1934.

Kurasama, H. : Studies on the biological production of fire pools in Tokyo. I. Jap. J. Ecol., 8, 3, 129 135, 1958. (in Japanese).

Kurashige, H. : The diurnal change of dissolved oxygen in relation to the solar radiation in Ohori (moat). J. Meteorol. Soc. Jap. (Kishô-Shûshi), Part 1. 10, 7, 373 382, 1932 ; Part 2. 10, 8, 482 489, 1932a ; Part 3. 11, 6, 253 266, 1933. (in Japanese).

: Chemical and biological observations of the ponds on the Kubiki Plain, Niigata Prefecture. Ibid. 11, 1, 9 13, 1933a. (in Japanese).

- : Spring diatom increase in relation to the nutrient salts and the meteorological elements. Geophys. Mag., 6, 1933b.

\& G. $\mathrm{K}_{\mathrm{AGEI}}$ : Seasonal variation of hydrogen ion concentration and water temperature in the Ohori (moat). J. Meteorol. Soc. Jap. (Kishô-Shûshi), 10, 7, 382 388, 1932. (in Japanese).

LAAKsonen, R.: Observation in the silica content of some ponds. Arch. Soc. Zool. Bot. Fenn. 'Vanamo'., 10, 2, 161 163, 1956.

: Über den täglichen Gang der Assimilation sowie die Folgen einer Künstlichen pH Senkung in einem Fischteich. Ibid., 11, 2, 182 186, 1957.

Liebmann, H. : Handbuch der Frischwasser- und Abwasserbiologie. Band I. MÜnchen, 1951.

- Ibid. Band II. 1958.

LiLLIERoth, S.: Über Folgen Kulturbedingter Wasserstandsenkungen für Macrophyten- und Planktongemeinschaften in seichten Seen des südschwedischen Oligotrophiegebietes. Acta Limnol., 3, 236 263, 1950.

Lund, J. W. G.: Studies on Asterionella formosa Hass. II. Nutrient depletion and the spring maximum. J. Ecology, 38, 1, 1 14, 1950.

- : Further observations on the seasonal cycle of Melosira italica (EHR.) Kütz. subsp. Subarctica O. MÜLler. Ibid., 43, 1, 90 102, 1955.

- Chemical analysis in ecology illustrated from Lake District tarns and lake. Proc. Linn. Soc. London, Sess. 167, 165 171, 1957.

MASHIKo, K.: A brief note on the inland waters of Hegura-jima, an isolated islet 
in the Sea of Japan. Jap. J. Limnol., 15, 1 2, 25 29, 1950. (in Japanese). - A note on the brackish-water Copepods. Jap. J. Ecol., 4, 1, 13 15, 1954. (in Japanese).

Matsudatra, Y.: Observation of Hase-ike pond in suburb of the City of Kobe. Sea and Sky (Umi-to-Sora), 11, 8, 191 198, 1931. (in Japanese).

- Chemical substances of the rain in Kobe City in the typhoon. Ibid., 17, 10, 412 419, 1937. (in Japanese).

: Chemical substances and other characters of the sea breeze observed in Kobe City when the typhoon came. Ibid., 17, 10, 420-425, 1937a. (in Japanese).

Matsuyama, K.: Seasonal fluctuation of the plankton communities of the small pond in the northern Settsu Province. Jubilee. Publ. Comm. Dr. Yoshida 60th Birth Day, 1, 660 670, 1939. (in Japanese).

MIKI, S. et al.: Reports of the biological survey in 'Sokonashi-ike' of the Tokara Islands. Bull. Osaka Mun. Mus. Nat. Hist., 4, 39 65, 1955. (in Japanese).

MiYad, D.: Vertical distribution of the hydrogen ion concentration in the stagnant water of certain eutrophic lakes. The Globe (Chikyû), 12, 6, 404 412, 1929. (in Japanese).

: Benthic fauna and its relation to the problem of lake types. Bot. Zool. (Tokyo), 5, 1, 331 336, 1937. (in Japanese).

_ : Limnolgical survey of Taiwan (Formosa). Arch. Hydrobiol., 35, 1 27, 1939.

- M. UÉno \& G. Tomita : Biological characteristics of the waters of Yangtz Delta (Reports on the limnological survey of Central China. I.). Shanghai Sizen-kagaku. Kenkyûsyo Ihô, 13, 3, 279 284, 1943. (in Japanese).

Mizuno, T.: Limnological studies of the freshwater ponds in the northern part of Osaka Prefecture. Mem. Osaka Univ. Lib. Art \& Educ. B, 1, 71 82, 1952.

- : Limnological studies of the freshwater ponds in the southern part of Osaka Prefecture. Ibid., 2, 113 124, 1953.

: Limnological studies of the freshwater ponds in the northern part of Shikoku Island in Japan. Ibid., 3, 90 98, 1954.

- Limnological studies of the freshwater ponds in the Harima Plain on the coast of the Inland Sea of Seto. Ibid., 4, 82 93, 1955.

: Limnological studies of the freshwater ponds on the coast of the Inland Sea of Seto (Okayama, Hiroshima and Oita Prefectures). Ibid., 5, 72 83, 1956.

: The plankton and the environmental conditions of the freshwater ponds on the coast of the Inland Sea. Jap. J. Limnol., 19, 2, 72 74, 1957. (in Japanese).

- Limnological studies of some groups of freshwater ponds on the coast of the Inland Sea in Japan. I, II. Mem. Osaka Univ. Lib. Art \& Educ. B, 6, 74 86, 1957a ; 7, 77 90, 1958.

: Water conditions and plankton of some lakes in Hokkaido. Ibid., 8, 99 113, 1959. (in Japanese). 
: The vertical distribution of plankton in Lake Otori-ike. Jap. J. Limnol., $20,4,145 \sim 150,1959$ a. (in Japanese).

: The chemical quality of water and the plankton of some ponds in the western suburbs of the City of Yamagata. Ibid., 20, 4, 181 184, 1959b. (in Japanese).

\& H. Fujishita : Ecological division of the lower part of Yodo River. - Relation between plankton and chemical condition of waters. Hyôgo Biol., 3, 1 5, 1956. (in Japanese).

, H. Hata \& I. Kôno: Seasonal succession of Daphnia pulex and the analysis of its external factors. I. Jap. J. Ecology., 10, 1, 1 6, 1960. (in Japanese).

\& T. Kosara : Chemical condition and plankton of Tomogashima. Nature Study, Ser. 2, 25 28, 1955 . (in Japanese).

MoRI, M. : Studies on the correlation between the chlorine content of water and the distribution of an algae in the lower course of the Gotô River. Jap. J. Limnol., 9, 1, 11 17, 1934. (in Japanese).

: Plankton of 'tame-ike' ponds on Takamatsu Plain. Bot. Zool. (Tokyo), 9, 12, 555 558, 1941. (in Japanese).

NAKAMura, K. et al.: An experiment of raising carp fingerling in farm pond, study in Gorobei-ôike. Bull. Freshwater Fish. Res. Lab., 7, 2, 19 44, 1958. (in Japanese).

NaUmann, E. : Einige neue Gesichtspunkte zur Systematik der Gewässertypen, mit besonderer Berücksichtigung der Seetypen. Arch. Hydrobiol., 20, 191 198, 1929.

___ : Grundzüge der Regionalen Limnologie. Binnengewässer 11, Stuttgart, 1932.

NygaARd, G. : Hydrobiologische Studien über dänische Teiche und Seen. Arch. Hydrobiol., 32, 523 692, 1938.

- : Hydrobiological studies in some ponds and lakes. Part II. The quotient hypothesis and some new or little known phytoplankton organisms. Kgl. Danske Vidensk, Selsk. Biol. Skrifter, 7, 1, 1 293, 1949.

Oshima, N.: A few knowledges on the abnormal condition of water in the fish culture ponds. Stud. Aqua. Prod. 26, 7, 228 250, 1931. (in Japanese).

Oнце, W.: Chemische und physikalische Untersuchungen norddeutscher Seen. Arch. Hydrobiol., 36, 337 423, 1934.

Pearsall, W. H.: Phytoplankton in the English Lakes. J, Ecology, 18, 2, 306 320, 1930.

- : The composition of the phytoplankton in relation to dissolved substance. Ibid., 20, 2, 241 262, 1932.

Pennak, R.W. : Freshwater Invertebrates of the United States. New York, 1953.

Rawson, D. S. : Some physical and chemical factors in the metabolism of lakes.

Amer. Ass. Advan. Sci., 10, 9 26, 1939.

: Algal indicators of trophic lake types. Limnol. \& Oceanogr., 1, 1, 18 
25, 1956.

Shelford, V.E. : Animal Communities in Temperate America. Geogr. Soc. Chicago, Bull., 5, 1913.

Schürte, K.E. \& J.F. Elsworth : The significance of large $\mathrm{pH}$ fluctutions observed in some south Africa Vleis. J. Ecology, 42, 1, 148 150, 1954.

Inquiry Comittee on the Economic Affair of the Snowy Agricultural District (Sekisetsu-chihô Nôson keizai Chôsasho): Survey of the snow density and its concluded substances. 5 34, 1934. (in Japanese).

Suith, G. M. : Phytoplankton of the inland lakes of Wisconsin. I. Bull. Wisconsin Geol. \& Nat. Hist. Surv., 1920.

- Ecology of the plankton algae in the Palisades Interstate Park, including the relation of control methods to fish culture. Roosvelt Wild Life Bull., 2, 2, 95 195, 1924.

: Freshwater algae of the United States. New York, 1950.

SugaWARA, K. : The seasonal variation of the occurrence of phytoplankton and the circulation of silicon in Lake Biwa. Jap. J. Limnol., 8, 3, 434 445, 1938. (in Japanese).

- Chemistry of rainfall. Science (Tokyo), 18, 11, 485 492, 1948. (in Japanese).

Suginome, M.: Observation on the process of winter egg formation of Daphnia carinata $\mathrm{K}_{\mathrm{ING}}$ and their reproductive mode in successive sexual generation. Bull. Freshwater Fish. Res. Lab., 8, 2, 1 14, 1959. (in Japanese).

Takayanagi, G. : The influence of the ocean upon the chemical constitutions of atmosphare. Part I. Bull. Chem. Soc. Jap., 62, 3, 249 251, 1941. (in Japanese).

TAKEUChI, T. : On the distribution of 'tame-ike' ponds. Geogr. Rev. Jap. (Chirigaku-Hyôron), 15, 4, 283 300, $1939 ; 15,5,319 \sim 342,1940$. (in Japanese).

Thienemann, A. : Der Sauerstoff im eutrophen und oligotrophen Seen. Binnengewässer 4, Stuttgart, 1928.

— : Tropische Seen und Seetypenlehre. Arch. Hydrobiol. Suppl., 9, 205 231, 1931.

Thummark, S. : Zur Soziologie der Süsswasserplanktons. Eine methodologischeökologische Studie. Folia Limnol. Scand., 3, 1 66, 1945.

Tiffany, L. H. \& M.E. Britton: The algae of Illinois. Chicago, 1952.

Tsuda, M.: Biological survey of Yodo River. (Osaka-fu Eisei-bu Kankyôeisei-ka) 1956. (in Japanese).

Tsuda, M. et al.: Biological survey of the polluted water in Kanzaki River. (Yodo-gawa Suishitsu Odaku Bôshi Renraku-Kyôgikai) 1959. (in Japanese).

UÉno, M. : Fundamentals of Limnobiology. Tokyo, 1935. (in Japanese).

- : Fauna Nipponica, Order Branchiopoda, 9, 1. Tokyo. 1937. (in Japanese).

- : Japanese freshwater Cladocera, a zoogeographical sketch. Annot. Zool. Jap., 17, 3〜4, 283 294, 1938.

: Freshwater fauna of the Districts on the Western Pacific. The Sea and Inland Waters on the Pacific. Tokyo, 1943, (in Japanese). 
: Fukami-ike. Shinano Educ. Library, 9, 1952. (in Japanese).

- Lakes of the Matsubara-Group. The Minamisaku Educ. Soc., 1954. (in Japanese).

— : The Lakes of Shimominachi and its environs. Shimominachi Educ. Soc.,. 1958. (in Japanese).

- The disharmonious lakes of Japan. Verh. internat. Ver. Limnol., 8, 217 226, 1958a.

UsPENSKI, E.E.: Eisen als Faktor für die Verbreitung niederer Wasserpflanzen, 9, 1 104, 1927.

Watanabe, T.: The 'tame-ike' ponds at Tsukeno Village and its plankton communities. Nara Educ. Soc., 233 272, 1952. (in Japanese).

: The water colors shown by the C.I.E. color language and the plankton of white muddy ponds. Jap. J. Ecolugy, 6, 2, 69 72, 1956. (in Japanese). WatANABE, H. : On the characters of running water in the carp-culture ponds. Stud. Apua. Prod. (Suisan Kenkiu-shi), 26, 5, 112 131, 1931. (in Japanese).

Watanabe, M. : Diurnal variation of temperature, oxygen, carbon dioxide contents and hydrogen ion cocentration of of fish pond water. J. Fsh., 35, 41 56, 1932. (in Japanese).

WAWRIK, F. : Limnologische Studien an Hochgebirgs-kleingewässer in Arlberggebiet I. Ost. Akad. d. Wiss. Math. Naturw. K1., Abt. 1, 163, 4 5, 277 296, 1954.

— : Hochgebirgs-kleingewässer in Arlberggebiet II. Ibid. Abt. 1, 164, 6 7, 367 387, 1955.

— : Waldviertler Fischteich. I. Ibid. Abt. 1, 164, 10, 887 907, 1956.

W Imann, R. : Biologie der Teich. (cited by Liebmann, 1958).

WeLCH, P. S. : Limnology. New York, 1952.

Wilhelm, J.: Kompendium der biologische Beurteilung des Wassers, 1914.

(Translation by M. Tsuda) Suidô kyôkai Zasshi, 129 131, 1944.

WUNDER, W., H. UTERMÖHL \& W. OHLE : Untersuchungen über die Wirkung von superphosphat bei der Düngung grösser Karpfenteich. III. Teil. Chemische und physikalische Charakteristik einiger Teich der Militisch-Trachenberger Grenzkreises. Z. Fischerei, 33, 575 613, 1935.

YАМАмото, K. : Rotifer fauna of Japanese inland waters. Jap. J. Limnol., 14, $1 \sim 6,41 \sim 48, \quad 141 \sim 145,189 \sim 194 ; 15,42 \sim 50 ; 16,24 \sim 30,68 \sim 74,81 \sim 91$; 18, 49 57, 1949 1956. (in Japanese).

YAMAMOTO, S. : The normal distribution of chloride in the pond waters of coastal districts. Jap. J. Limnol., 11, 1, 14 22, 1941. (in Japanese).

YAMAZAKI, T. : Studies of the disharmonious inland waters. Contr. Physiol. Ecol. Kyoto Univ., 40 51, 1945. (in Japanese).

Yoshimura, S. : Ojaga-ike at Kanamachi in Chiba Prefecture. J. Geogr., 37, 442, 725 726, 1925. (in Japanese).

: A limnological reconnaissance of Tane-ga-ike, Tottori, with some studies of Koyama-ike and Tôgô-ike. Googr. Rev. Jap., 5, 11, 961 984, 1929. (in 
Japanese).

: Horizontal distribution of dissolved oxygen and hydrogen ion concentration in several Japanese lakes. Geophys. Magazine, 3, 1, 1 10, 1930.

: Chemical substances of Japanese lakes I. Introduction. Jap. J. Limnol., 1, 1, 25 31, 1931. (in Japanese).

: Classification of the lake types. Bull. Ôtsuka Geogr. (Ôtuska Chirigakkai Rombunshû), II. 159 185, 1933. (in Japanese).

: Limnology of the three crater (maar) lakes of Oga Peninsula, Akita Pref., Japan. Imp. Acad., 9, 10, 631 634, 1933a.

- : Nitrogenous compounds and phosphate dissolved in the waters of the disharmonic lake type. Bull. Jap. Soc. Sci. Fish., 3, 4, 185 190, 1934. (in Japanese).

: The amount of nitrogenous compounds dissolved in the waters of harmonic lakes of Japan. II. Ibid. 4, 3, 183 189, 1935. (in Japanese).

: The effect of salt-breeze on the chemical composition of freshwater lakes near the sea. Arch. Hydrobiol., 30, 2, 345 351, 1936.

: Limnology. Tokyo, 1937. (in Japanese).

\& D. Mryadi : Limnological observations of two crater lakes of Miyake Island, western North Pacific. Jap. J. Geol. \& Geogr., 13, 3〜4, 339 352, 1936. 
(Mizuno, T.)

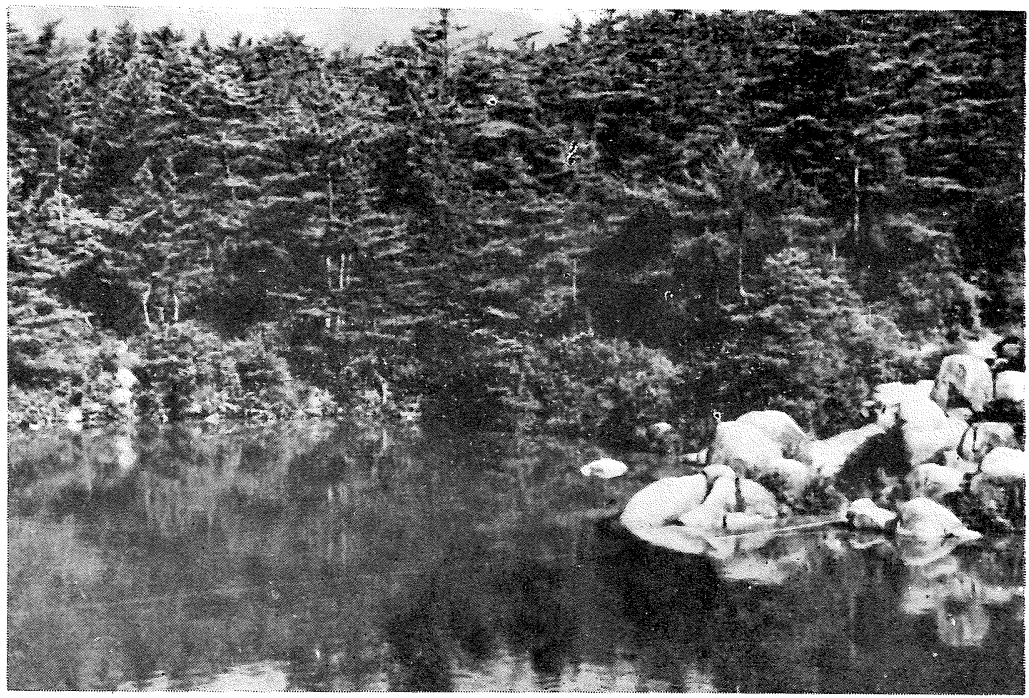

Fig. 37. Pond No. 22 at Kôyôen, Hyôgo pref. (Oligotrophic type)

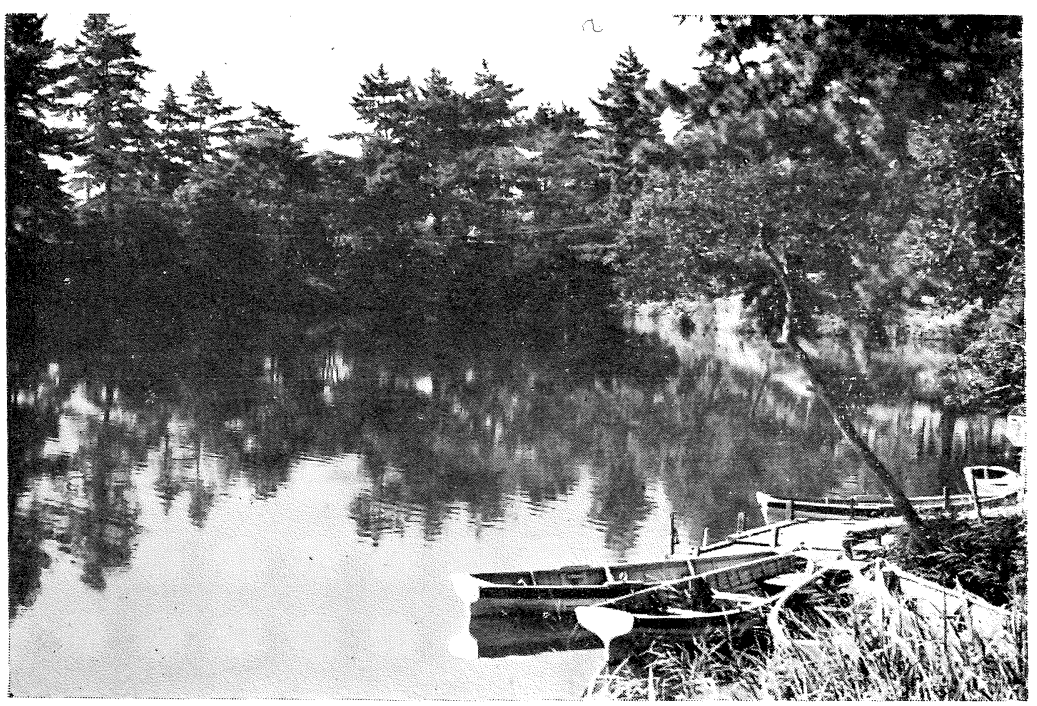

Fig. 38. Shimo-ike Pond at Itami City. (Mesotrophic type) 
JAP. J. LimNoL. [Vol. 22, 1961]

Plate IV

(Mizuno, T.)

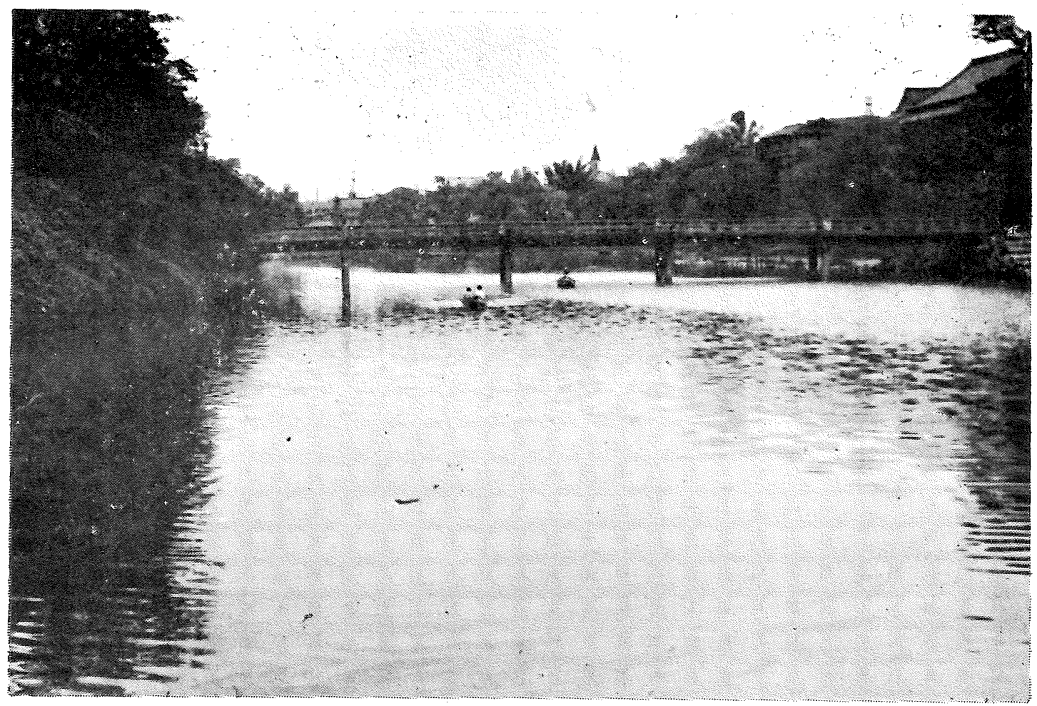

Fig. 39. Chausuyama-ike Pond at Tennôji in Osaka City. (Eutrophic type)

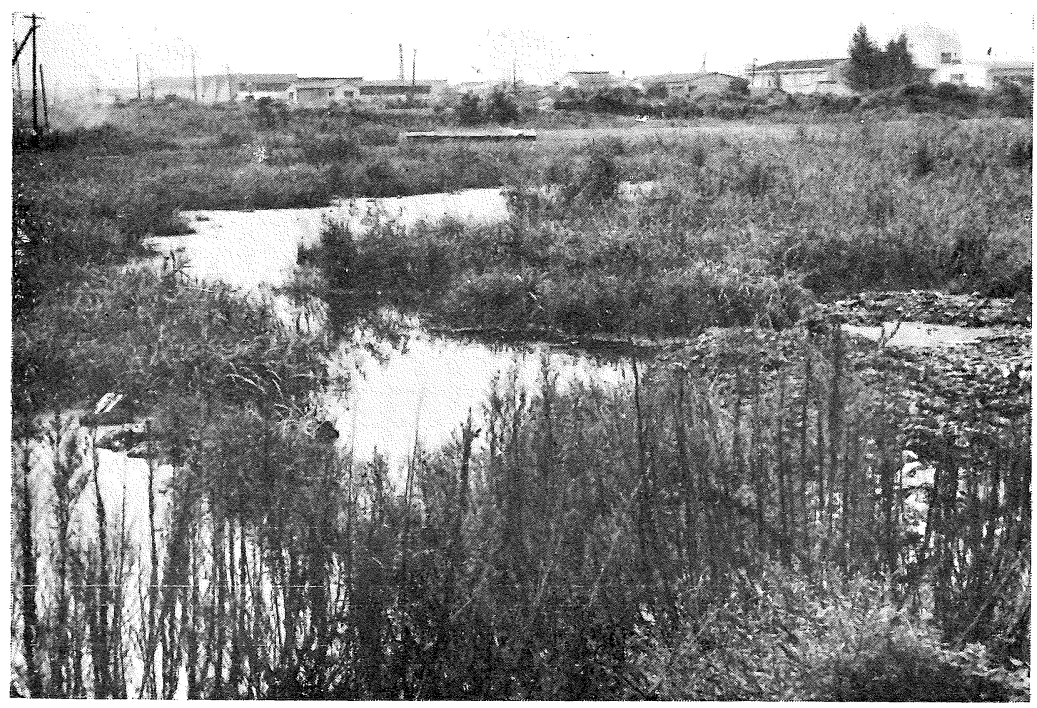

Fig. 40. Pond No. 198 in the suburbs of Osaka City. (Dystrophic type) 
JAP. J. LimnoL. [Vol. 22, 1961]

Plate V

(Mizuno, T.)

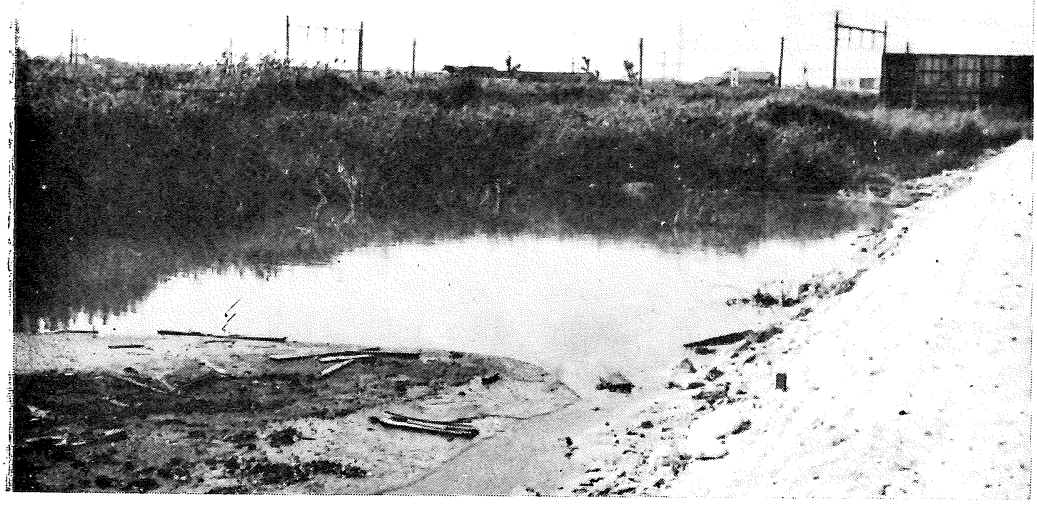

Fig. 41. Kanai-jûkô Pond at Amagasaki City.

(Polytrophic type)

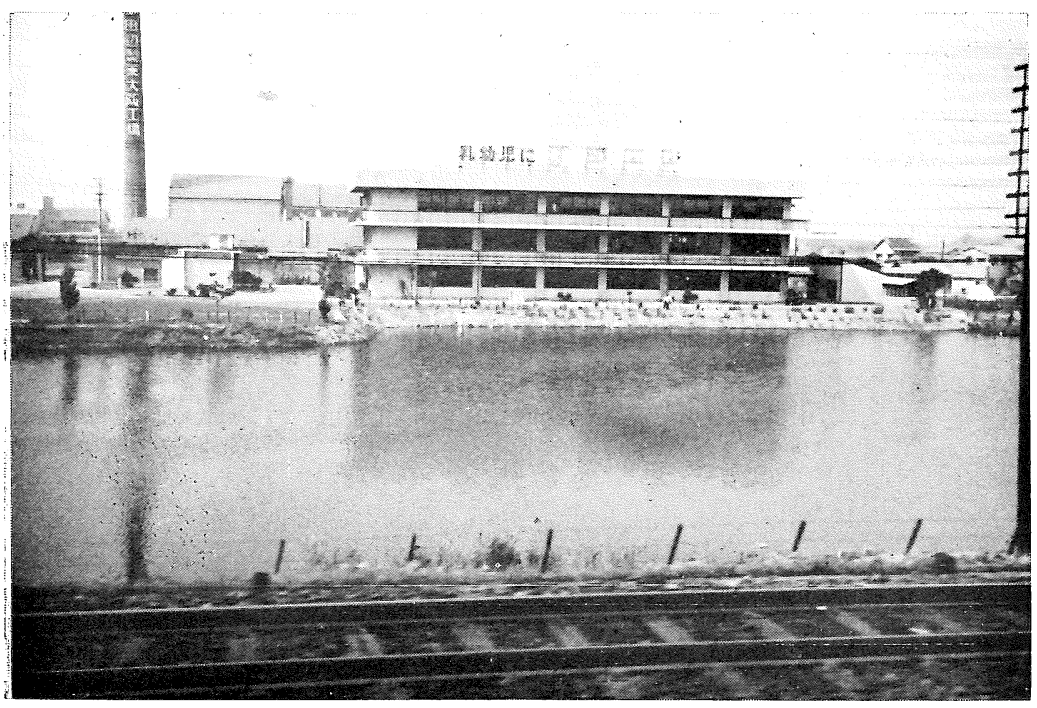

Fig. 42. Tanabe-seiyaku Pond in Osaka City.

(Polytrophic type) 
JAP. J. Limnol. [Vol. 22, 1961]

(Mizuno, T.)

Plate VI

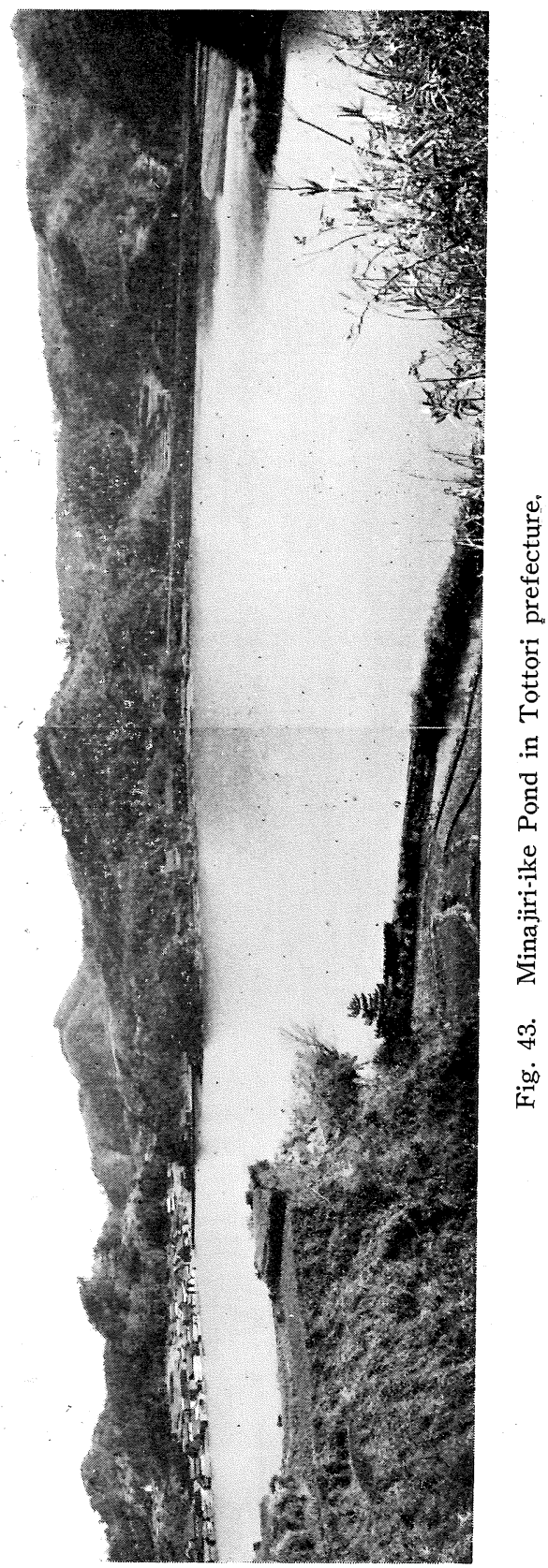


(Mizuno, T.)

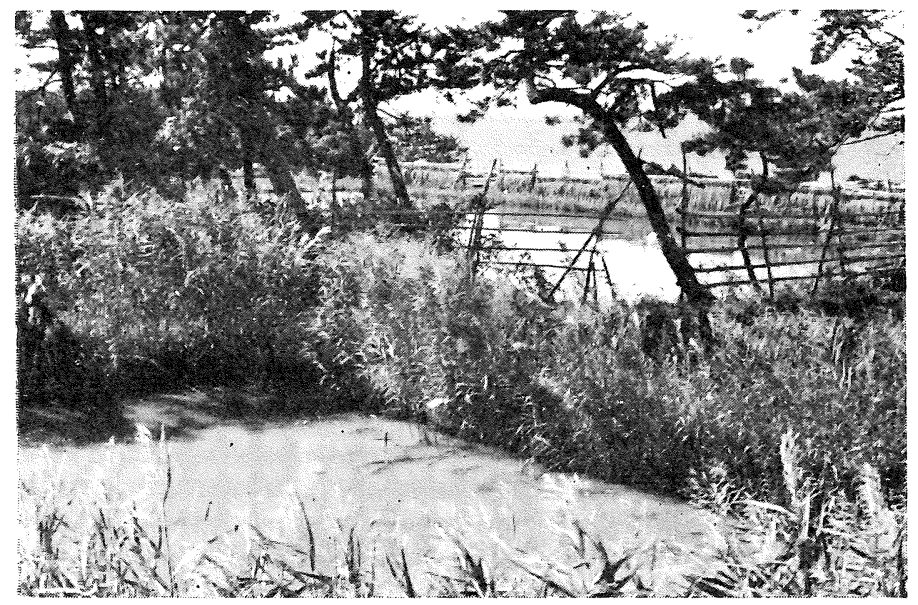

Fig. 44. Pond No. 4 and pond No. 5 on the western coast of Sadoga-shima Island.

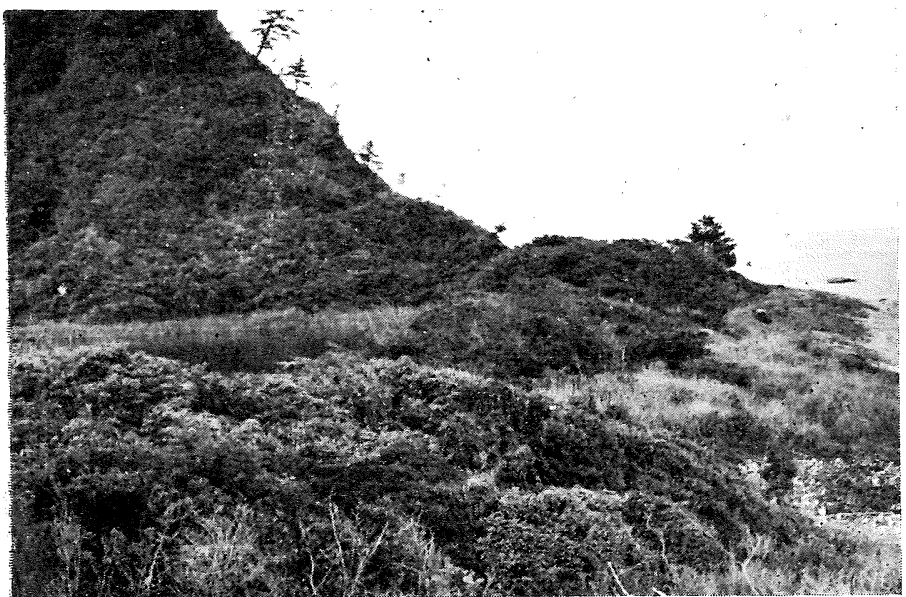

Fig. 45. O-ike Pond on the eastern coast of Okino-shima Island. 